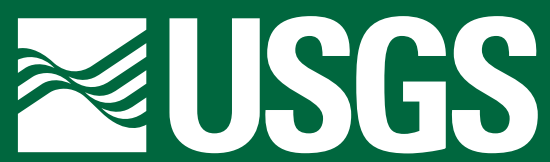

\title{
A Hydrologic Primer for New Jersey Watershed Management
}

Water-Resources Investigations Report 00-4140
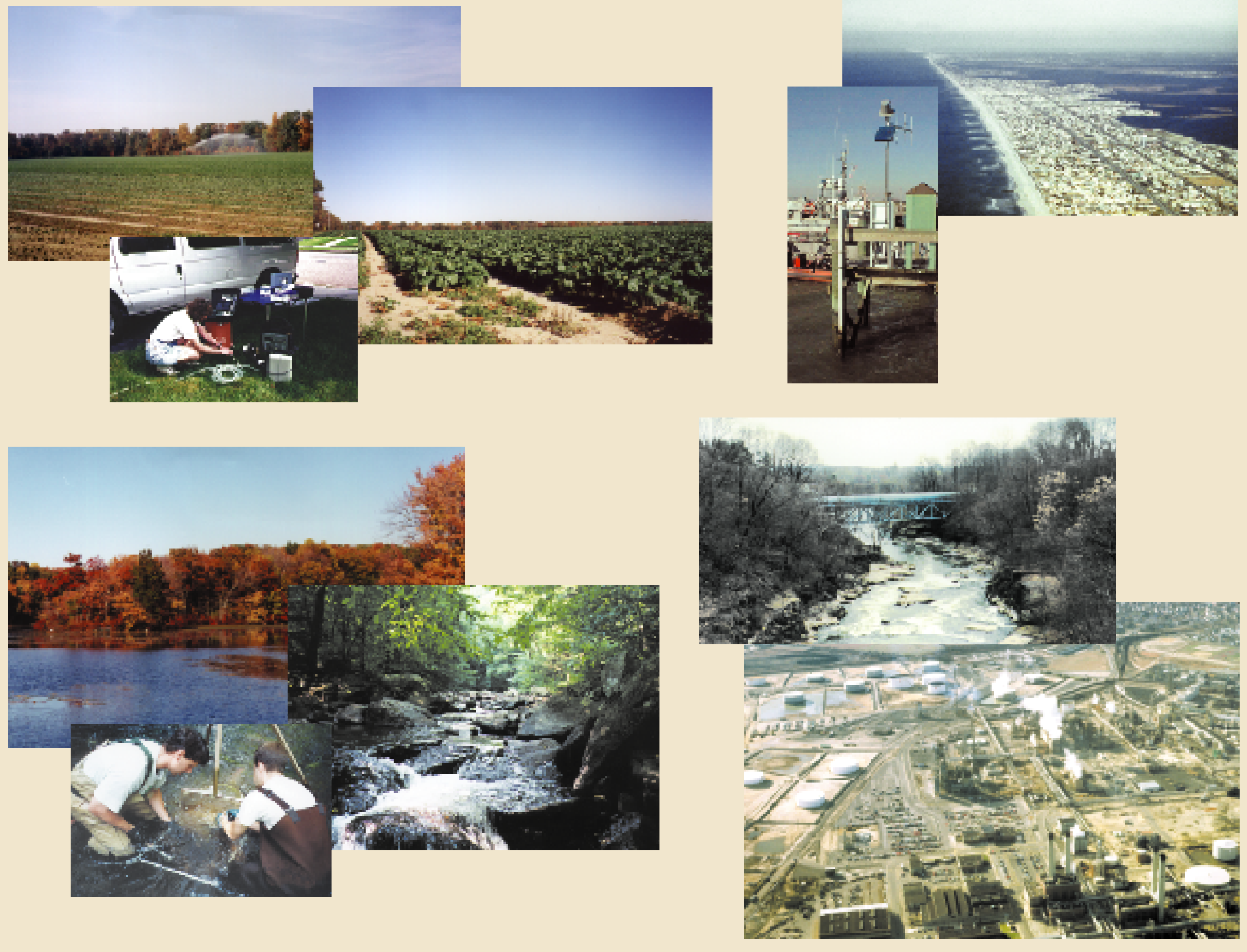

Prepared in cooperation with

NEW JERSEY DEPARTMENT OF ENVIRONMENTAL PROTECTION

U.S. Department of the Interior

U.S. Geological Survey 


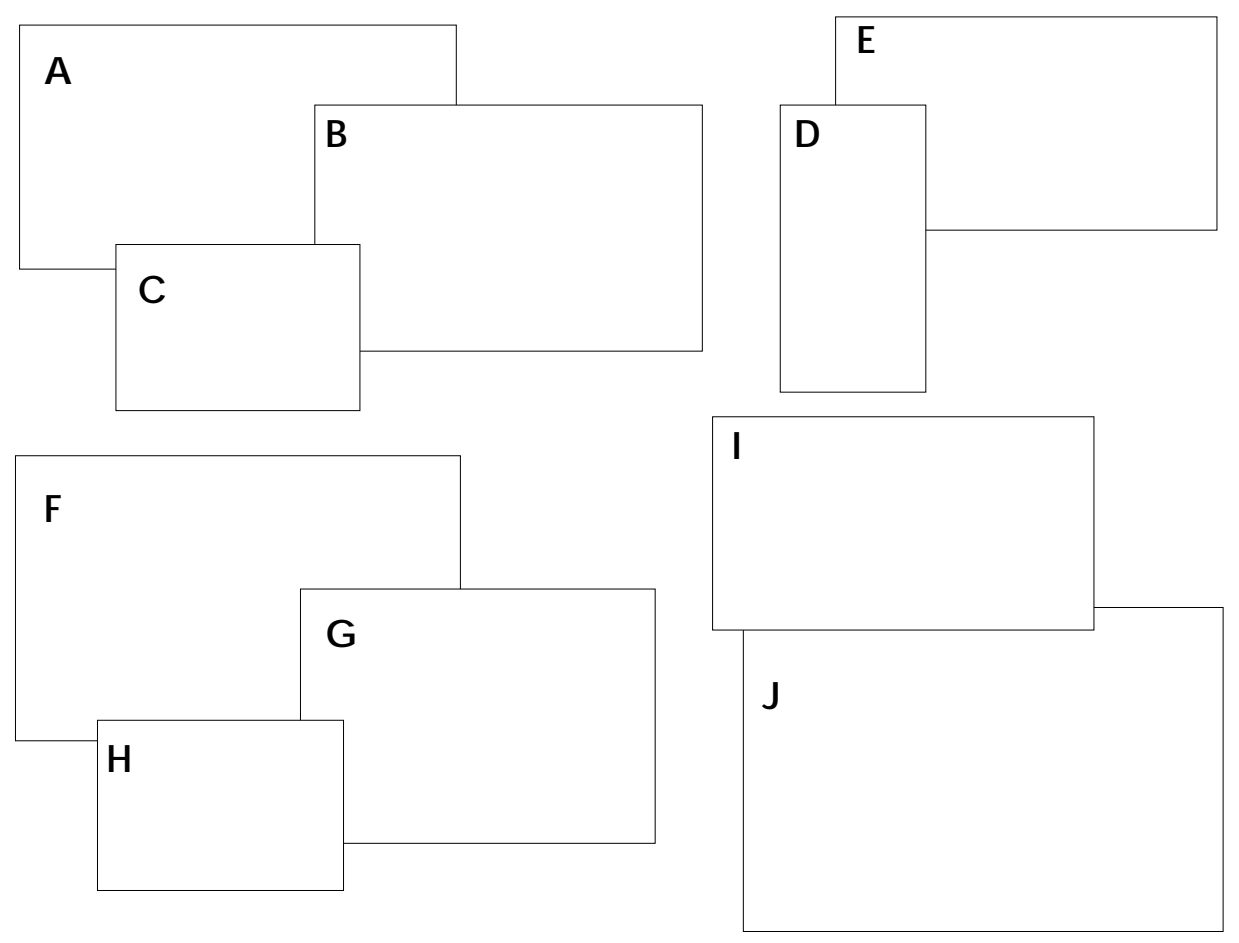

A. Crop irrigation in central New Jersey.

B. Row crops in central New Jersey.

C. Sampling ground water from a domestic well. (Photograph by Rick Clawges)

D. Tide-telemetry (left) and weather-monitoring equipment at Cape May Harbor at U.S. Coast Guard Training Center, Cape May, New Jersey. (Photograph by John Stepnowski, National Ocean Service)

E Development along the New Jersey coast, Seaside Heights. (File photograph U.S. Geological Survey, West Trenton, New Jersey)

F. Red Valley Lake, Monmouth County, New Jersey.

G. Lamington River near Pottersville, New Jersey. (Photograph by Jonathan Kennen)

H. Collecting macroinvertebrates in the Rockaway River at Boonton, New Jersey. (Photograph by Mark Ayers)

I. Passaic River at Little Falls, showing the aqueduct that carries water from the Passaic River to the Wanaque Reservoir. (Photograph by Timothy Reed)

J. Industrial emmissions into the atmosphere along the lower Delaware River, New Jersey. (File photograph, U.S. Geological Survey, West Trenton, New Jersey)

Cover layout and design: William Ellis, Jr.

Text formatting: Ingrid Heerwagen 


\section{A Hydrologic Primer for New J ersey Watershed Management}

By Martha K. Watt

U.S. GEOLOGICALSURVEY

Water-Resources Investigation Report 00-4140

Prepared in cooperation with the New J ersey Department of Environmental Protection

West Trenton, New J ersey

2000 


\title{
U.S. DEPARTMENTOF THE INTERIOR \\ BRUCE BABBIT, Secretary
}

\section{U.S. GEOLOGICALSURVEY}

Charles G. Groat, Director

\begin{abstract}
ABOUT THIS REPORT--This hydrologic primer is designed to provide an introduction to basic hydrologic concepts and a "snapshot" of selected data-collection efforts used to assess the quality and quantity of water resources in New Jersey, and is not an exhaustive compilation of all data-collection programs that are underway in the State. Additional data collected by the N.J. Department of Environmental Protection, other Federal, State, and local governments agencies, and private organizations that are not presented in this report may be available. Additionally, because the Watershed Management Program is a dynamic program that is continually evolving, the number and locations of data-collection sites and the locations of watershed-management-area boundaries presented in this report may not reflect those in the current program.
\end{abstract}

For additional information write to:

\section{District Chief}

U.S Geological Survey Mountain View Office Park 810 Bear Tavern Road, Suite 206 West Trenton, NJ 08628
Copies of this report can be purchased from:

\author{
U.S. Geological Survey \\ Branch of Information Services \\ Box 25286
}

Denver, CO 80225-0286 


\section{CONTENTS}

Why read this report? $\mathbf{1}$

What is a watershed? 2

Introduction $\mathbf{3}$

Acknowledgments $\mathbf{4}$

General hydrologic concepts $\mathbf{1 0}$

Basic definitions $\mathbf{1 0}$

The hydrologic cycle 12

Water budget 13

Surface-water system $\mathbf{1 4}$

Ground-water system 23

Water quality $\mathbf{2 5}$

Water-quality standards

26

Water use $\mathbf{2 8}$

Description of the study area

Geology and hydrology

34

Land use $\mathbf{4 1}$

Population 46

Water-resource data $\mathbf{4 8}$

Surface-water data $\mathbf{4 8}$

Streams 48

Flow-duration curves

63

Base flow 65

Flood-prone areas and wetlands $\quad 66$

Lakes and reservoirs $\quad \mathbf{6 8}$

Ground-water data $\mathbf{7 1}$

Ground-water levels $\mathbf{7 1}$

Major withdrawal wells $\mathbf{7 7}$

Water-quality data $\mathbf{8 0}$

Surface-water quality $\mathbf{8 1}$

Biological data 86

Ground-water quality $\mathbf{8 8}$

Saltwater monitoring 94

Potential contaminant sources 96

New Jersey Pollutant Discharge Elimination System (NJPDES) sites 96

Landfills and hazardous-waste sites $\mathbf{9 8}$

Atmospheric data $\quad 99$

Weather stations 99

Air-monitoring points 100

How to get involved 101

List of contacts 102

Suggested reading 103

Selected references 104 


\section{ILLUSTRATIONS}

Figure 1-2. Maps showing the:

1. Location of N.J. Department of Environmental Protection water regions and watershed management areas in New Jersey $\mathbf{3}$

2. Location of N.J. Department of Environmental Protection watershed management areas and wetlands in the:

2a. Northeast water region $\mathbf{5}$

2b. Northwest water region $\mathbf{6}$

2c. Raritan water region 7

2d. Lower Delaware water region $\mathbf{8}$

2e. Atlantic Coastal water region 9

3. Schematic diagram of the hydrologic cycle $\mathbf{1 2}$

4. Schematic diagrams showing gaining and losing streams $\mathbf{1 4}$

5. Map showing New Jersey watersheds that extend beyond the State boundary $\mathbf{1 6}$

6. Map showing location of selected reservoirs and the Delaware and Raritan Canal $\mathbf{1 7}$

7. Hydrograph of the discharge of two rivers in New Jersey during Hurricane Floyd, September 16-17, 199922

8. Schematic diagram showing types of openings in rocks and sediments that are capable of holding water $\mathbf{2 3}$

9. Diagram showing flow paths of ground water as it moves from recharge areas to discharge areas 24

10. Diagram showing example of N.J. Department of Environmental Protection water-quality standards, classifications, and criteria

27

11-12. Pie chart of:

11. Water used in New Jersey in 1994 , by use category $\mathbf{3 1}$

12. Ground-water and surface-water withdrawals in the five water regions of New Jersey 32

13. Map showing New Jersey spans parts of four physiographic provinces 34

14. Schematic diagrams of ground-water flow systems in four representative hydrogeologic terrains in New Jersey 39

15. Map showing land use in New Jersey, 1991-93 43

16. Graphs showing (a) population density in New Jersey from 1880 to 1990 and

(b) population densities of the five water regions in New Jersey in 1990, and projected densities for 2010 and $2040 \quad 47$

17-19. Maps showing the:

17. Streamflow-gaging stations active in New Jersey in water year $1997 \quad 49$

18. Low-flow partial-record stations, crest-stage partial-record stations, and tide-gaging stations active in New Jersey in water year $1997 \quad 51$

19. Tide-telemetry stations, flood-warning systems, and weather stations active in New Jersey in $1999 \mathbf{5 2}$

20. Graph showing the relation of daily mean discharge at the Toms River near Toms River, N.J., streamflow-gaging station to monthly precipitation at the Toms River, N.J., weather station 62

21. Plot showing flow-duration curves for four stream sites in different physiographic provinces in New Jersey 


\section{ILLUSTRATIONS--Continued}

Figure 22. Schematic diagrams showing ground-water flow associated with wetlands 67

23. Graph showing the cumulative capacity of selected large reservoirs and lakes and population of New Jersey from 1890 to $1990 \quad \mathbf{7 0}$

24. Map showing U.S. Geological Survey ground-water monitoring wells active in New Jersey in $1997 \mathbf{7 1}$

25. Hydrographs of water levels measured in observation wells in the Coastal Plain of New Jersey, 1988-98 72

26-28. Maps showing the:

26. Location of Water-Supply Critical Areas in New Jersey $\mathbf{7 6}$

27. Location and amount of water withdrawn for public supply from the major aquifers in the Coastal Plain of New Jersey in $1997 \quad \mathbf{7 8}$

28. Location and amount of water withdrawn for public supply from aquifers in northern New Jersey in $1997 \quad 79$

29. Graphs showing concentrations of two nutrients, nitrate and phosphate, in streamflow during a typical storm $\mathbf{8 2}$

30-33. Maps showing the:

30. Surface-water-quality sampling sites and estuarine and tidal river monitoring sites active in New Jersey in $1998 \quad 85$

31. N.J. Department of Environmental Protection Ambient Biomonitoring Network sites in New Jersey during 1992-96 $\mathbf{8 7}$

32. Ground-water-quality and saltwater-monitoring sites in New Jersey 92

33. Nitrate concentrations in water from wells in New Jersey $\mathbf{9 3}$

34. Graph showing annual withdrawals from the Kirkwood-Cohansey aquifer system and late summer chloride concentrations in water from selected wells at (a) Point Pleasant Beach and (b) Seaside Heights, N.J., 1918-95 95

35-36. Maps showing the:

35. New Jersey Pollutant Discharge Elimination System surface-water-discharge sites in New Jersey $\mathbf{9 7}$

36. Weather stations and the air-monitoring station in New Jersey

99

\section{TABLES}

Table 1. Information on selected reservoirs and large lakes in New Jersey $\mathbf{1 8}$

2. U.S. Environmental Protection Agency and New Jersey State primary and secondary drinkingwater standards as of November $1996 \quad 29$

3. Characteristics of aquifers and wells in New Jersey $\mathbf{4 0}$

4. Selected information for continous streamflow-gaging stations in New Jersey through water year 199754

5. Characteristics of surface-water bodies 69

6. Contaminants commonly detected in drinking water derived from ground-water sources 


\section{BOXES}

Box A. Streamflow-gaging station and hydrograph 20

B. Soils and their relation to the hydrologic system 36

C. Cartographic tools used in hydrologic studies 44

D. Constructing a water-table or potentiometric-surface map $\mathbf{7 4}$

E. Dissolved oxygen $\mathbf{8 4}$ 


\section{A HYDROLOGIC PRIMER FOR NEW JERSEY WATERSHED MANAGEMENT}

By Martha K. Watt

\section{WHY READ THIS REPORT?}

- To learn basic concepts about watersheds,

- To learn what information (data) is collected in your watershed and other watersheds in New Jersey,

- To learn why the data are collected and what they are used for, and

- To provide information needed to get involved and make a difference in the management and health of your watershed.

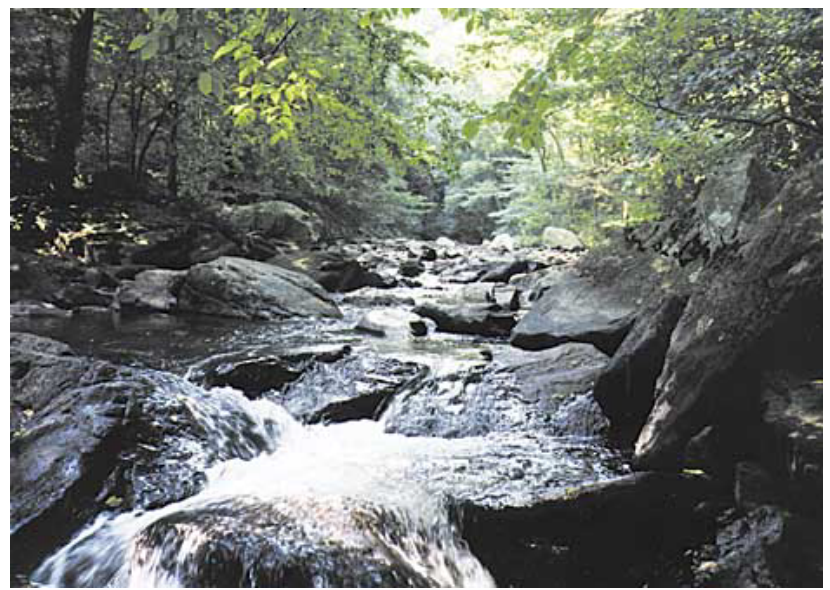

Lamington River near Pottersville, New Jersey. (Photograph by Jonathan Kennen) 


\section{WHAT IS A WATERSHED?}

A watershed is an area of land that drains all the streams and rainfall to a common outlet such as the outflow of a reservoir, mouth of a bay, or any point along a stream channel (McCann, 1992). The word watershed is sometimes used interchangeably with drainage basin or catchment. Ridges and hills that separate two watersheds are called the drainage divide. The watershed consists of surface water--lakes, streams, reservoirs, and wetlands--and all the underlying ground water (McCann, 1992).

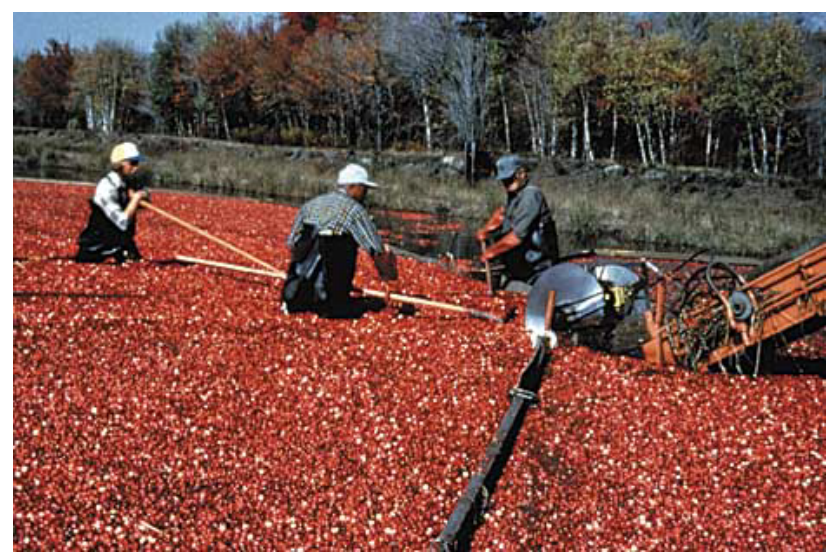

Cranberry harvesting in the New Jersey Pinelands. (Courtesy of the Pinelands Commission) 


\section{INTRODUCTION}

The U.S. Geological Survey (USGS) and the N.J. Department of Environmental Protection (NJDEP), and many other agencies and organizations are striving to educate the public about New Jersey's water resources. In 1996, the NJDEP began implementing a "watershed management approach" to maintain the physical, chemical, and biological integrity of New Jersey's waters. This approach concentrates on managing individual watershed areas by (1) defining the physical geographic boundaries of the watersheds, (2) basing water policy on sound scientific principles, and (3) developing partnerships with the public--the people most affected by watershed-management policies.

New Jersey can be divided into five water regions as defined by the NJDEP: the Northeast, Raritan, Northwest, Lower Delaware, and Atlantic Coastal water regions (fig. 1). Each water region has been divided into three to five "watershed-management areas," each of which encompasses a particular group of major rivers (fig. 2a-e). Each watershedmanagement area consists of many smaller watersheds.

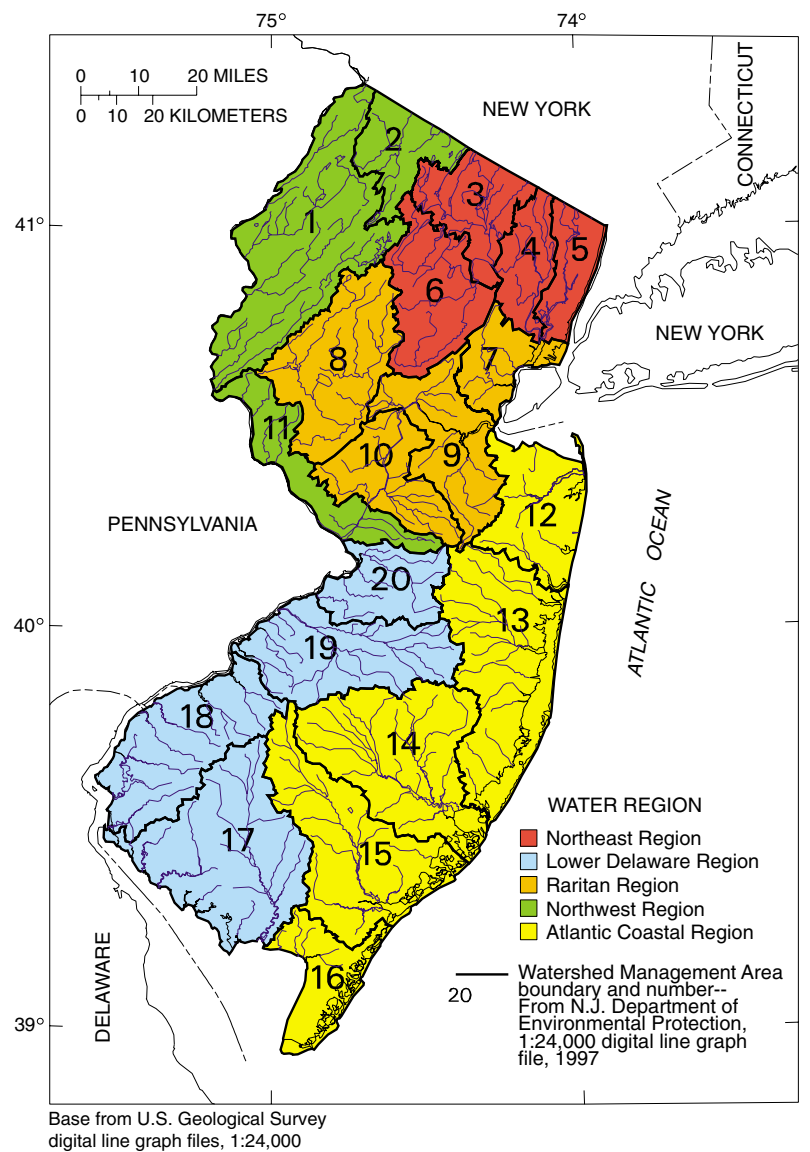

Figure 1. Location of N.J. Department of Environmental Protection water regions and watershed management areas in New Jersey. Each water region contains three to five watershed management areas. Each of these areas encompasses a particular group of major rivers and consists of many smaller watersheds.

\section{In 1996, the N.J. Department of Environmental Protection began implementing a "watershed management approach" to maintain the physical, chemical, and biological integrity of New Jersey's waters.}


Hydrologic data collected by Federal and State government agencies are invaluable as resources to policymakers who make decisions that affect the use of water in a particular watershed. The purpose of this report is to educate water-resource managers, policymakers, government officials, and the public about hydrologic concepts and the water-resource data needed to make informed decisions about water-management issues. ("Hydrologic" means relating to the occurrence, distribution, movement, and chemistry of all waters of the Earth (Fetter, 1980)). The first part of the report describes basic hydrologic concepts and includes explanations of the hydrologic cycle, the water budget, the surfacewater and ground-water flow systems, water-quality concepts and standards, and water use. The second part of the report summarizes the types of waterresource data that are available from Federal and State government agencies. Instructions on how to obtain the data and contact the appropriate Federal and State agencies, as well as suggestions for additional reading, also are included.

Hydrologic data collected by
Federal and State government
agencies are invaluable as
resources to policymakers who
make decisions that affect the
use of water in a particular
watershed.

\section{ACKNOWLEDGMENTS}

The author gratefully acknowledges the many specialists and colleagues who provided guidance, assistance, and expertise for this report. My thanks extend to those who reviewed this document for technical accuracy and appropriate information: Lance Miller, Kyra Hoffman, James Mumman, Karen Schaffer, Robert Canace, Michael P. Bleicher, Dave McPartland, and Fran Varacalli of the NJDEP; Eric Evenson, David Stedfast, Robert Schopp, Jacob Gibs, Dale Simmons, Jessica Hopple, and Marion Fisher of the USGS. Technical assistance was provided by my colleagues at the USGS-William Ellis, Robert Nicholson, Kathryn Hunchak-Kariouk, Michael Deluca, Jonathan Marlow, John Nawyn, Donald Rice, and Eric Vowinkel--and by Richard Albers of the Delaware River Basin Commission. 


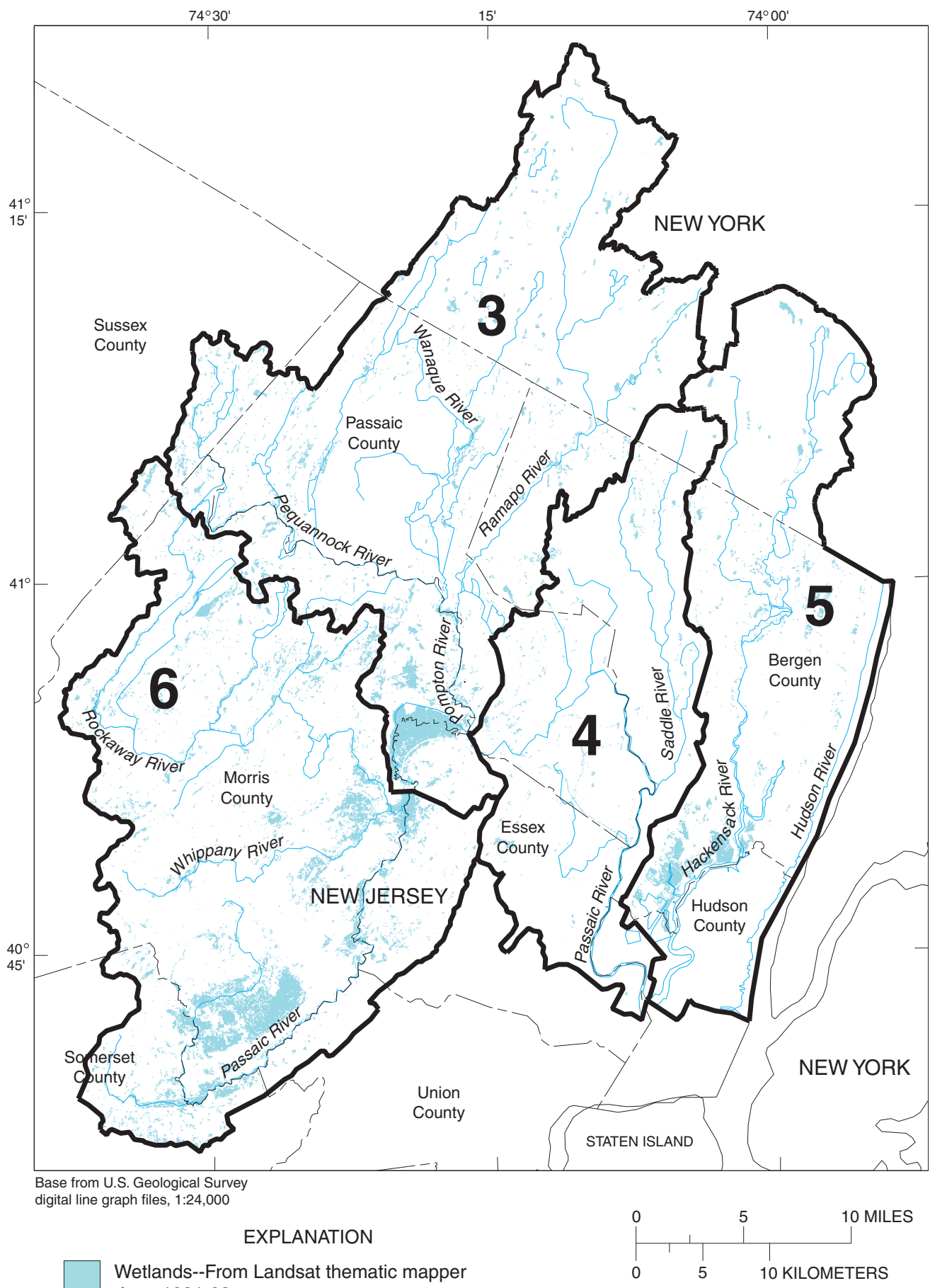

Wetlands--From Landsat thematic mapper data, 1991-93

WATERSHED MANAGEMENT AREA

3 Pompton, Pequannock, Wanaque, and Ramapo Rivers

4 Lower Passaic River and Saddle River

5 Hackensack and Hudson Rivers, and Pascack Brook

6 Upper Passaic, Whippany, and Rockaway Rivers

Watershed Management Area boundary--From N.J.

Department of Environmental Protection, 1:24,000

digital line graph file, 1997

Figure 2a. Location of N.J. Department of Environmental Protection watershed management areas and wetlands in the Northeast water region. 


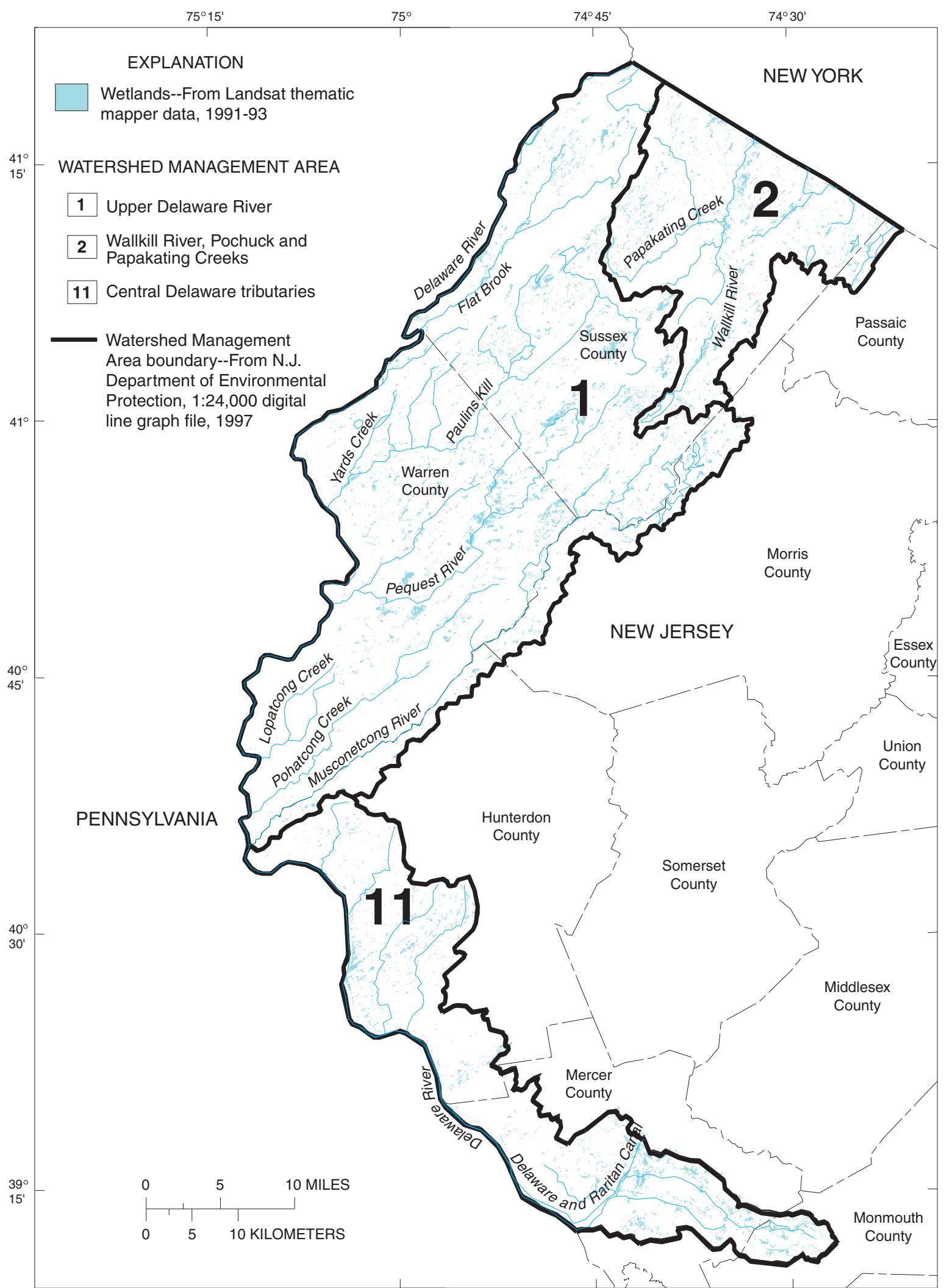

Base from U.S. Geological Survey

digital line graph files, 1:24,000

Figure 2b. Location of N.J. Department of Environmental Protection watershed management area and wetlands in the Northwest water region. 


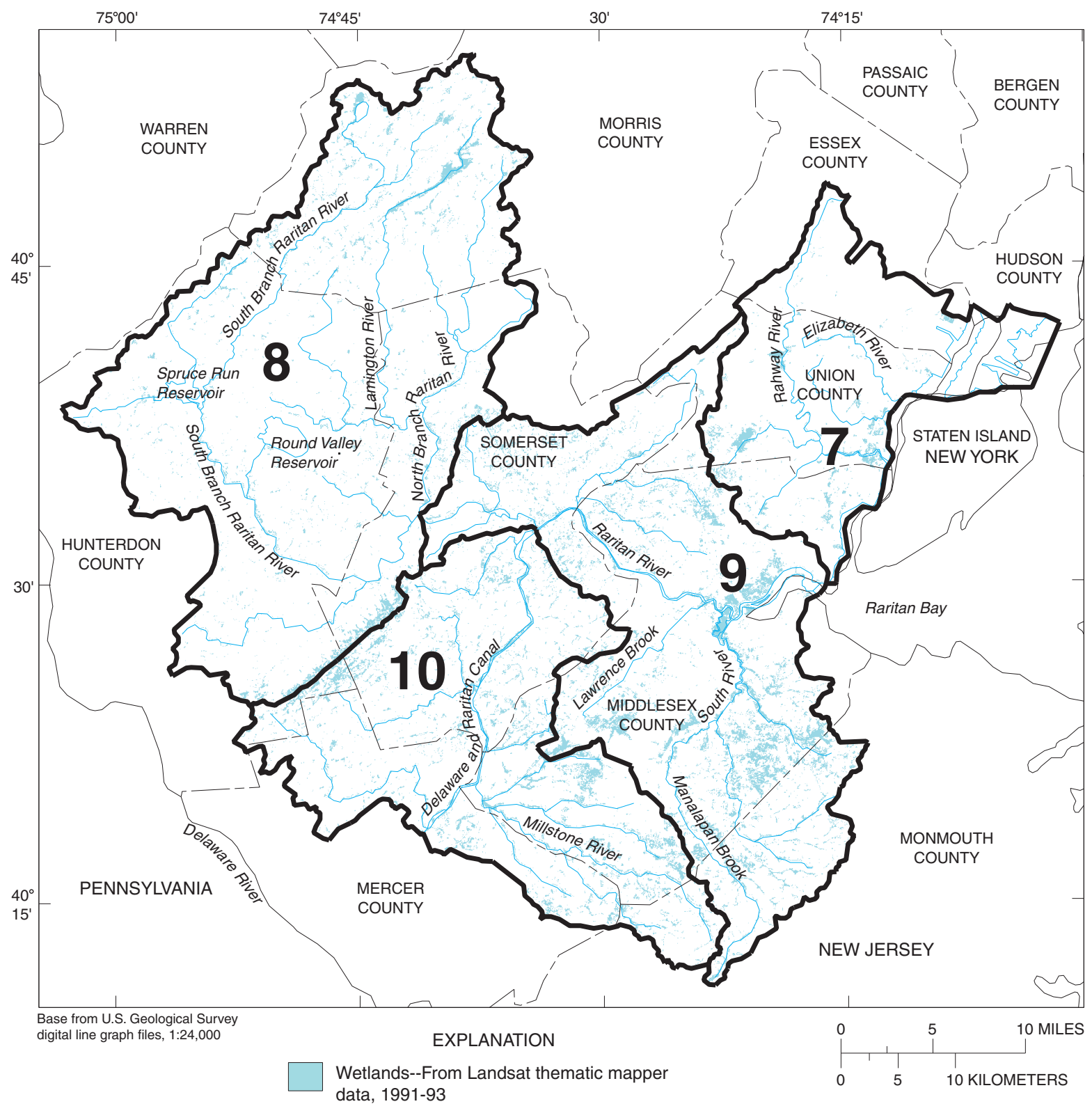

\section{WATERSHED MANAGEMENT AREA}

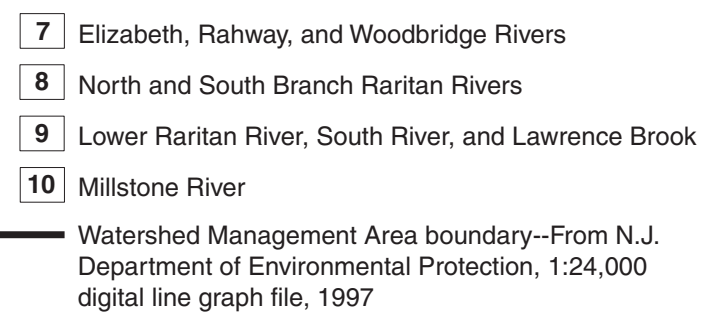

Figure 2c. Location of N.J. Department of Environmental Protection watershed management area and wetlands in the Raritan water region. 


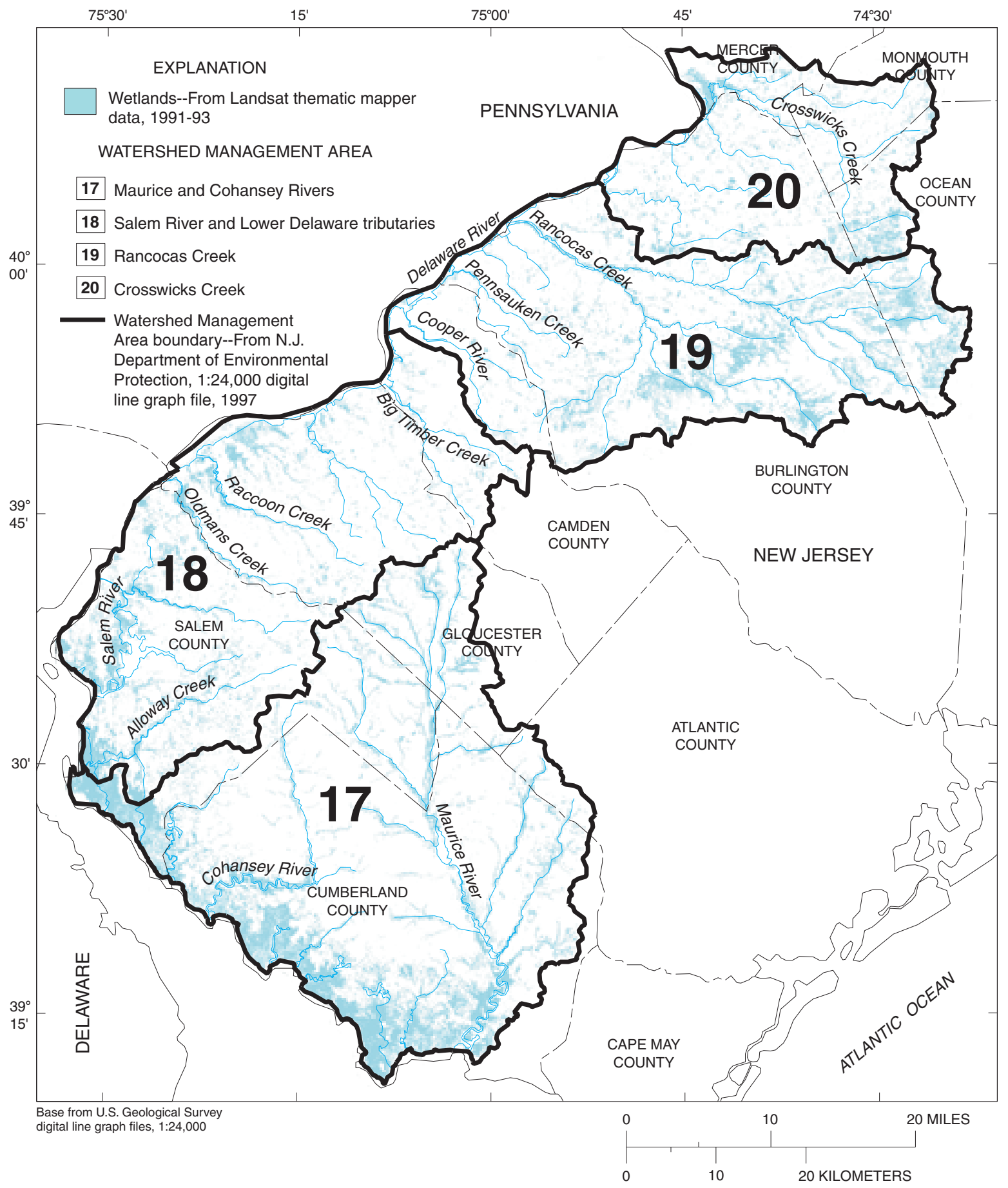

Figure 2d. Location of N.J. Department of Environmental Protection watershed management area and wetlands in the Lower Delaware water region. 


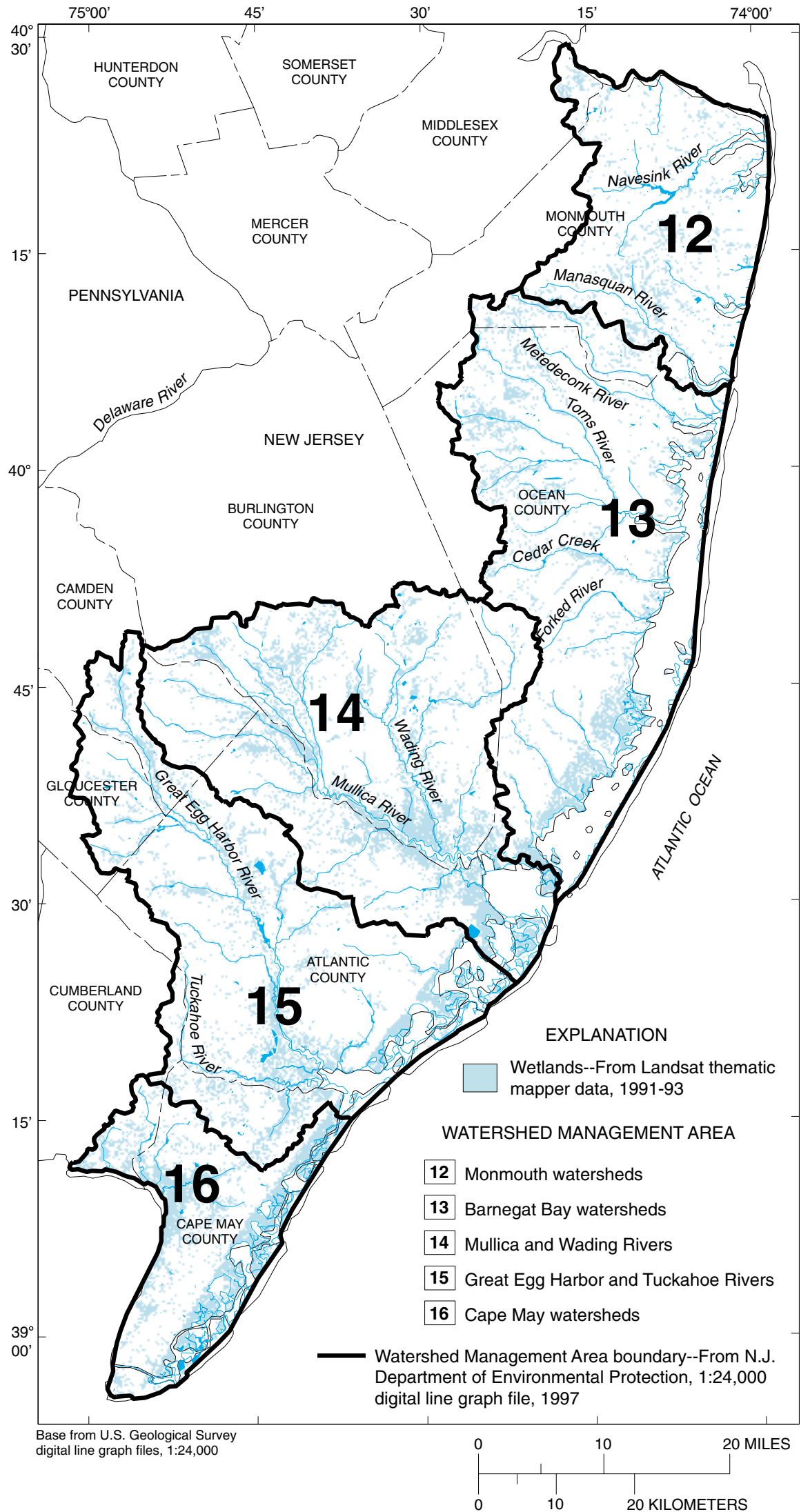

Figure 2e. Location of N.J. Department of Environmental Protection watershed management area and wetlands in the Atlantic Coastal water region. 


\section{GENERAL HYDROLOGIC CONCEPTS}

\section{Basic definitions}

Key terms used in this report include--

ATMOSPHERIC DEPOSITION--The process by which dust and chemicals in the atmosphere are deposited on a surface through precipitation, such as rain or snow, or through settling or adsorption (Lear, 1997).

AQUIFER--Layer(s) of either unconsolidated sediments or consolidated rock with interconnected voids, such as fractures, that will yield water in a usable quantity to a well or spring.

BASE FLOW--Sustained or fair-weather streamflow. In most streams, base flow is composed largely of ground-water discharge (Langbein and Iseri, 1960).

CARBONATE ROCK--A rock that consists primarily of limestone or dolomite. Carbonate rock can be highly permeable. (See "permeability," below.)

CONFINED AQUIFER--An aquifer that is bounded above and below by sediments or rocks of lower permeability (confining unit).

CONFINING UNIT--Layer(s) of rock or unconsolidated sediments with low permeability relative to immediately adjacent rock or sediment layers.

DRAWDOWN--The lowering of the water table in an unconfined aquifer or the potentiometric surface in a confined aquifer caused by pumping ground water from wells.

HYDRAULIC HEAD--The energy of a water mass, which is a function of elevation, pressure, and velocity. A measure of hydraulic head in an aquifer is the level to which water rises in a well. Differences in hydraulic head over distance cause ground water to flow.

JOINT--A type of fracture in which displacement of the rock does not occur.

PERMEABILITY--A property of a layer of rock or unconsolidated sediments that determines how easily a fluid, such as water, can move through it. Sands and gravels have high permeabilities; silts and clays have low permeabilities. 
POROSITY--The ratio of the volume of open (void) spaces in a rock or sediment through which fluid can flow to the total volume of the rock or sediment.

POTENTIOMETRIC SURFACE--A surface that represents the level to which water will rise in tightly cased wells. The water table is the potentiometric surface of an unconfined aquifer. (See "unconfined aquifer," below.)

RECHARGE--The addition of water to the saturated zone. Recharge can result from the infiltration of precipitation, from the flow of water from a surface-water body into an aquifer, or from the injection of water through an injection well.

SATURATED ZONE--The zone in which the openings (voids) in the rocks or soil are filled with water at pressure greater than atmospheric. The water table is the top of the saturated zone in an unconfined aquifer.

SPRING--A point where the ground-water surface intersects the land surface and ground water flows freely from sediments or rocks onto the land or into a surface-water body.

STREAMFLOW--The rate at which surface water moves through a stream channel. Often referred to as discharge in reports by the USGS.

UNCONFINED AQUIFER--An aquifer that is near land surface and is not overlain by a confining unit. Also called a water-table aquifer.

UNSATURATED ZONE--The zone between the land surface and the water table. The openings (voids) contain water at less than atmospheric pressure, as well as air and other gases.

VALLEY FILL--A body of unconsolidated sediment (glacial drift or till) deposited within a valley by glaciers.

WATERSHED--The land area that drains all the streams and rainfall to a common outlet, such as the outflow of a reservoir, the mouth of a bay, or any point along a stream channel (McCann, 1992). Sometimes referred to as a drainage basin or catchment.

WATER TABLE--The upper surface of the saturated zone, below which the openings in the rock are completely filled with water. At the water table, the water pressure equals atmospheric pressure. 


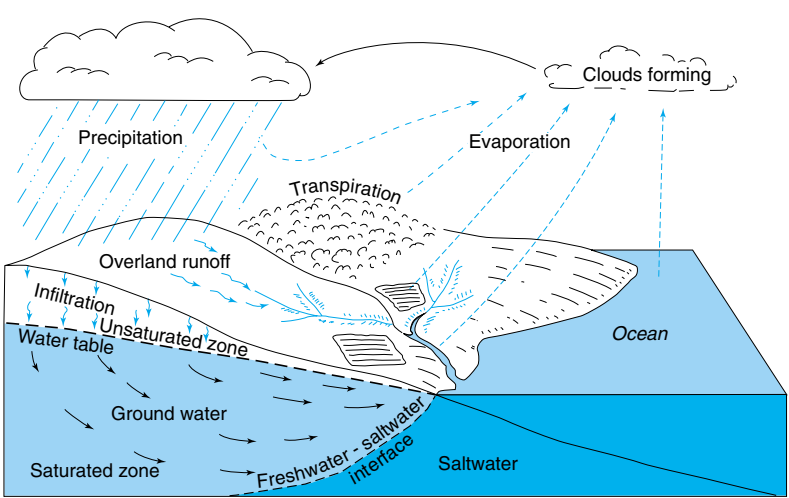

Figure 3. Schematic diagram of the hydrologic cycle (modified from Heath, 1983). Water moves constantly through the hydrologic cycle. Rain runs over the land surface and into streams, which discharge into the ocean. Some rain infiltrates into the ground-water system and discharges to streams or the ocean. Transpiration and evaporation return water to the atmosphere, completing the cycle.

\section{The hydrologic cycle}

Water is everywhere--in the atmosphere (air), streams, lakes, and rivers, and in the ground. We take it for granted. We never think about the fact that all the water in the world is connected to and caught up in the hydrologic cycle. The hydrologic cycle refers to the constant movement of water above, on, and below the Earth's surface (Heath, 1983, p. 5). Although the hydrologic cycle really has no beginning or end, the cycle can be said to begin as rain falls to the land surface and surface-water bodies, such as lakes, rivers, and the ocean (fig. 3). Some of the rain that falls on the land surface soaks into the ground. Some of this water works its way down through the soil to the water table--the top of the saturated zone. This process is called infiltration. Once it reaches the water table, the water is called ground water. Ground water either moves through the shallow part of the ground (horizontally near the ground surface as interflow) and discharges to a surfacewater body--a stream, a lake, or the ocean--or continues to flow downward to other, deeper aquifers (recharge). Once the ground is saturated, or has absorbed all the water that it can, like a sponge, the remaining rain runs over the land surface and into stream channels. This process is called overland flow (overland runoff or direct runoff). Overland flow also occurs when rainfall exceeds the infiltration rate--the rate at which water is absorbed by the sediments. The water in a stream is made up of precipitation, overland flow, and ground-water discharge. Evaporation takes place at the surface of streams, lakes, and the ocean, and on the land surface, returning water to the atmosphere. Plants also use the water by drawing it up through their root systems and returning it to the atmosphere (transpiration). The evaporated and transpired water (evapotranspiration) condenses and forms clouds and, ultimately, rain, completing the hydrologic cycle.

\section{Hydrologic cycle refers to the constant movement of water above, on, and below the Earth's surface.}




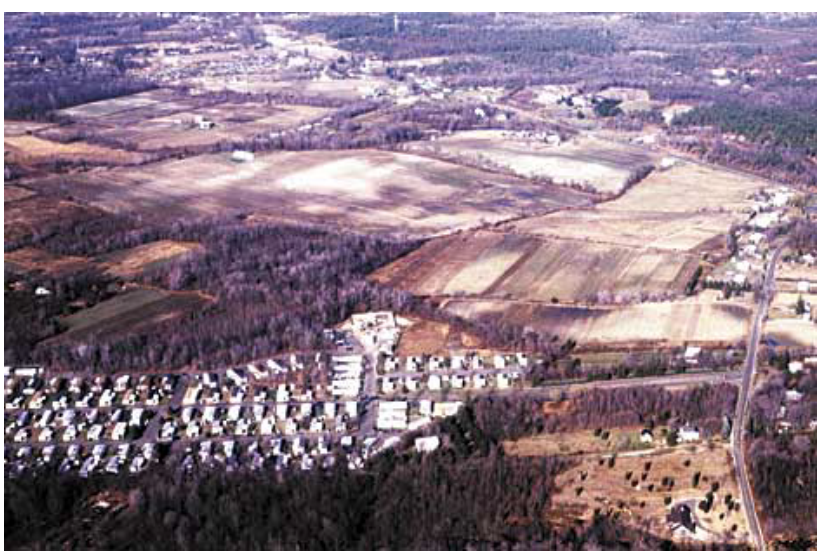

Development encroaching on agricultural land in southern New Jersey. (File photograph, U.S. Geological Survey, West Trenton, New Jersey)

\section{Water budget}

Each component of the hydrologic cycle--precipitation, recharge, streamflow, evaporation, transpiration, and ground- and surface-water withdrawals, as well as changes in the amount of water stored in the ground (ground-water storage) and in reservoirs, lakes, and the ocean (surface-water storage)--can be assigned a value in order to create a water budget. The water budget considers all waters, both surface and subsurface, entering, leaving, or stored within the watershed, and must always balance. The water budget provides a basis for evaluating change. Perhaps citizens of a town are thinking of rezoning an area to allow the building of condominium complexes, shopping malls, or new industries. These new facilities will require water. Questions that would need to be considered might include--how much water will be needed? From what source, ground water or surface water? Is enough water available? And, if so, for how long? How will this development affect wells and streams in the area? The estimated change in the water budget is one factor that can be considered in determining whether enough water is available to meet the additional demands. It is important to remember that when a new water demand is added or an existing demand is increased, the other components of the water budget must be adjusted to compensate for the change. For example, an increase in withdrawals from wells to supply a growing population may reduce the amount of ground water that reaches a stream, affecting the fish in the stream, the towns downstream that use the stream for water supply, and the quality of water in the stream. 


\section{Surface-water system}

One part of the hydrologic system, the surfacewater system, is made up of all the water that is present at the Earth's surface, such as rivers, streams, lakes, ponds, canals, reservoirs, and the ocean. As it rains, water drops may fall directly on one of these surface-water bodies, or it may fall on the land surface first and then travel over land and into the surface-water body (overland flow). Streams, lakes, and oceans are located at topographic low points, so all water flows toward them. Streams typically originate at topographic high points. The uppermost reach of a stream is called its headwaters. The land area from which surface water drains into a stream system is called its watershed or drainage basin. Streams in a watershed can be classified according to stream "order." A small, unbranched stream, typically a headwaters stream, is a first-order stream. When two first-order streams join, they form a second-order stream. A third-order stream has tributaries that are first- and second-order streams. Streams also can be classified as "gaining" or "losing." A gaining stream accumulates water as it flows to lower elevations. Water seeps into a gaining stream from its banks and channel bottom. A losing stream loses water as it flows to lower elevations. Water seeps out of the sides and bottom of a losing stream and into its banks (fig. 4).
GAINING STREAM

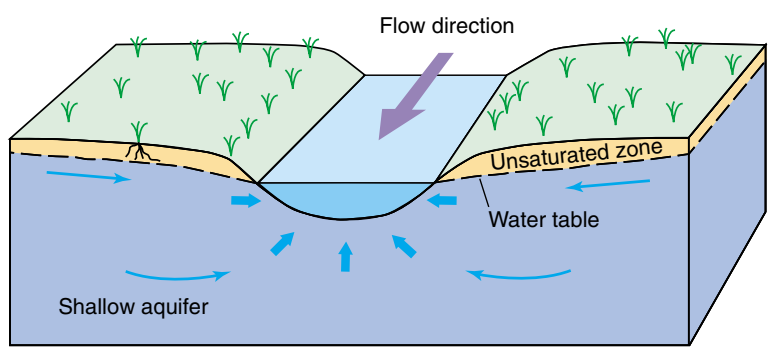

LOSING STREAM

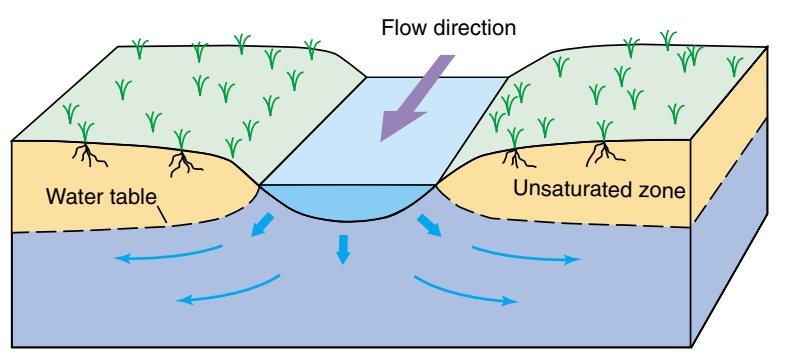

Figure 4. Gaining and losing streams (from Winters and others, 1998). Gaining streams receive water from the ground-water system. Losing streams lose water to the ground-water system. Note the height of the water table in relation to stream height. The water table adjacent to losing streams is lower than the stream level. The water table adjacent to gaining streams is higher than the stream level.

A gaining stream accumulates water as it flows to lower elevations. Water seeps into a gaining stream from its banks and channel bottom. A losing stream loses water as it flows to lower elevations. Water seeps out of the sides and bottom of a losing stream and into its banks. 
Watersheds differ in size. Major watersheds drain the largest rivers and all of their tributaries. For example, watersheds in parts of New York, Pennsylvania, New Jersey, and Delaware, with a total area of $12,765 \mathrm{mi}^{2}$ (square miles) excluding the surface area of Delaware Bay (fig. 5), drain into the Delaware River (U. S. Geological Survey, 1986a). Smaller watersheds may drain only the area surrounding a first-order stream. Watersheds are natural features that are unrelated to political boundaries. The headwaters and only 17 percent of the total watershed of the Wallkill River are within New Jersey. The Wallkill River flows north and discharges into the Hudson River in New York State. The Passaic and Hackensack Rivers, in contrast, have their headwaters in New York State, but 84 and 69 percent of their watersheds, respectively, lie in New Jersey (U.S. Geological Survey, 1986a) (fig. 5). Most of the streams and rivers in the Northwest water region and all of the streams and rivers in the Lower Delaware water region drain into the Delaware River, which drains into the Atlantic Ocean. Rivers in the Atlantic Coastal, Northeast, and Raritan water regions drain into the Atlantic Ocean. All of these large watersheds contain hundreds of smaller subbasin areas. The USGS has divided all the stream systems in New Jersey into 896 subwatersheds (Ellis and Price, 1995). The watershed designations are important for cataloging water data, monitoring and regulating water use, and planning and describing water-use activities. (Ellis and Price, 1995).

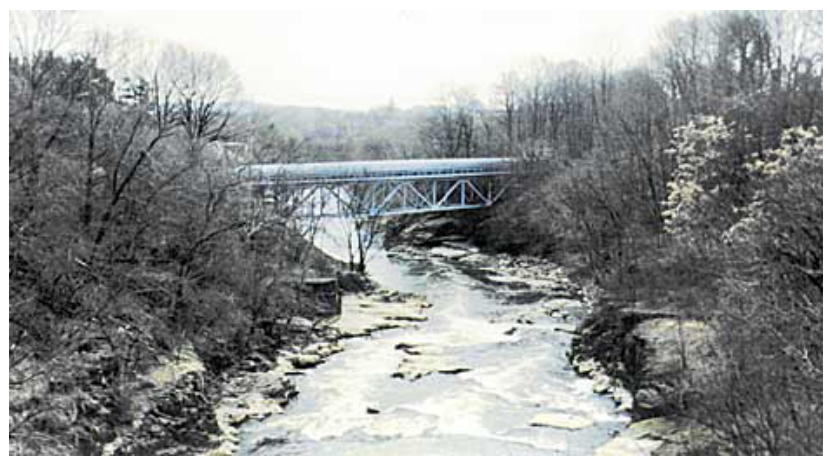

Passaic River at Little Falls, New Jersey showing the aqueduct that carries water from the Passaic River to the Wanaque Reservoir. (Photograph by Timothy Reed) 


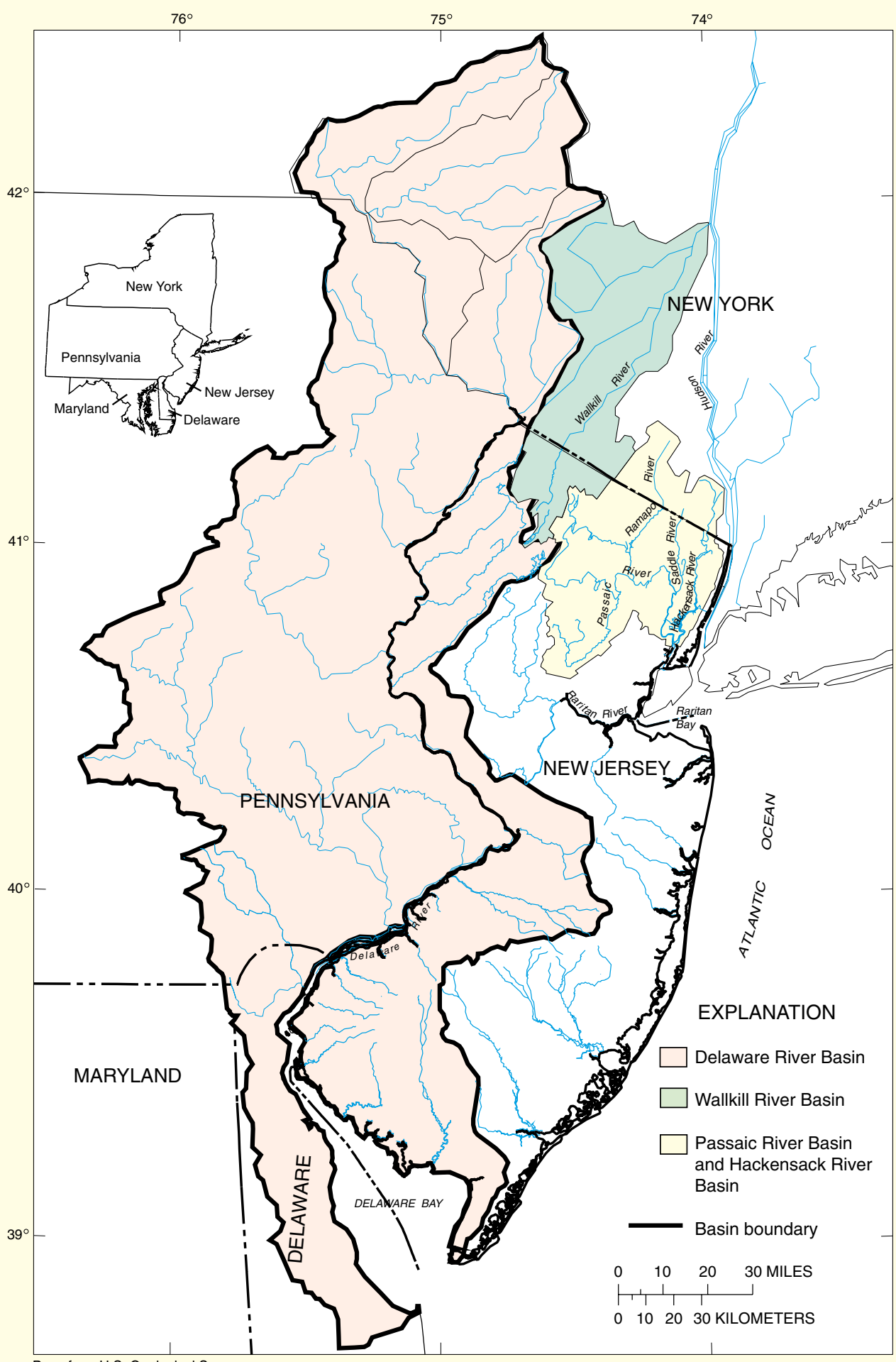

digital line graph files, 1:100,000

Figure 5. New Jersey watersheds that extend beyond the State boundary. The Delaware River Basin encompasses parts of New York, Pennsylvania, New Jersey, and Delaware and covers 12,765 square miles. Only 17 percent of the Wallkill River Basin, its headwaters, is in New Jersey. In contrast, most of the Passaic and Hackensack River Basins (84 and 69 percent, respectively) are in New Jersey, but their headwaters are in New York. 
Reservoirs are built on a stream to collect the flow of the stream for a variety of uses. Most reservoirs in New Jersey were built to supply the public with drinking water and also are used for recreation. Reservoirs also are used to store water for release back into the stream during times of drought to maintain a given volume of water in the stream, usually for water supply for an intake downstream. Maintaining adequate flow downstream from reservoirs is important for several reasons. The flow provides an ecological balance for the animals living in the stream, may dilute contaminants, or may be needed for use in industrial cooling or power generation. Most reservoirs in New Jersey are in the northern part of the State (fig. 6) and are used for drinkingwater supply. The availability of water from aquifers in the northern part of the State is not as great as that from aquifers in the southern part of the State. Consequently, water demands in densely populated northern New Jersey make reservoirs a necessity. Reservoirs affect both the amount and quality of streamflow. The release of reservoir water supplements streamflow during dry periods. Reservoirs and lakes provide the added benefit of reducing the severity of flooding during times of high precipitation and high flow. Sediments lining the bottom of the reservoir act as filters that trap nutrients and contaminants. The stream habitat in the area around the reservoir and downstream also is altered by the regulation of flows provided by the reservoir. Information on selected reservoirs and large lakes in New Jersey is listed in table 1.

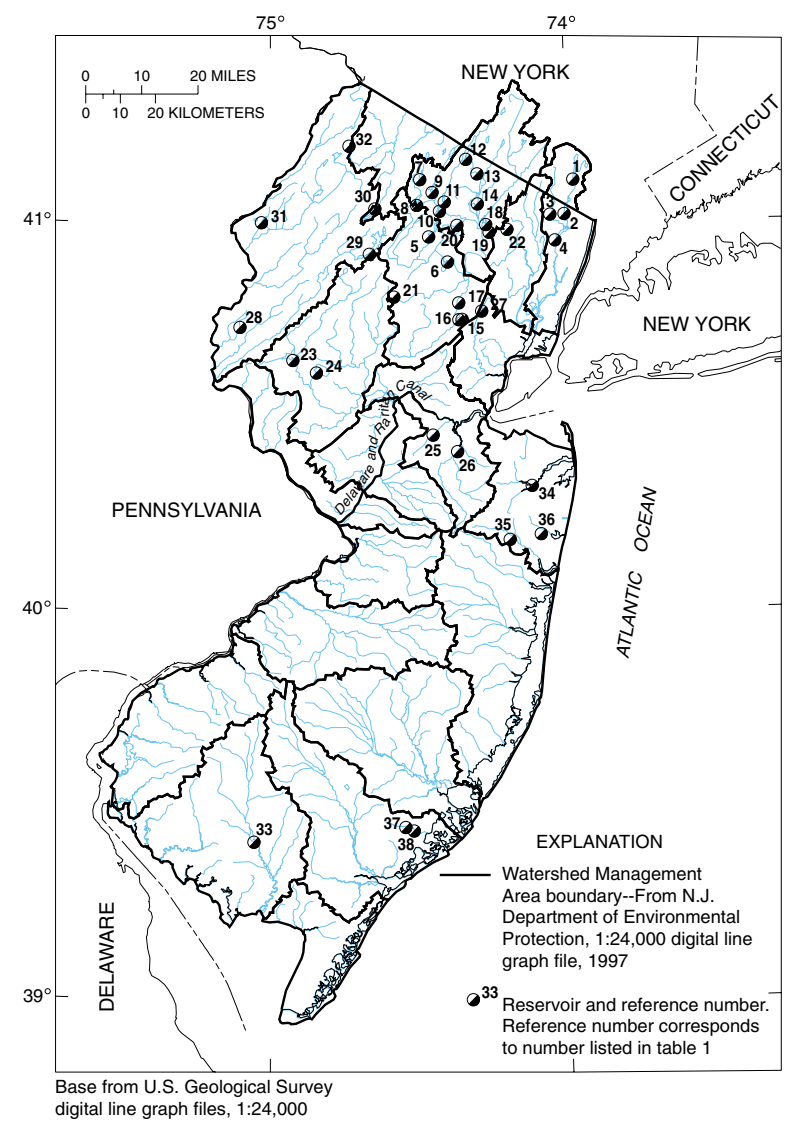

Figure 6. Location of selected reservoirs and the Delaware and Raritan Canal. Most of the reservoirs are in northern New Jersey where the ground-water resources are insufficient to supply the large population as a result of the geologic characteristics of the rocks. This makes the reservoirs a necessity.

\section{The availability of water from aquifers in the northern part of the State is not as great as that from aquifers in the southern part of the State. Consequently, water demands in densely populated northern New Jersey make reservoirs a necessity.}


Table 1. Information on selected reservoirs and large lakes in New Jersey

[USGS, U.S. Geological Survey; NJDEP; New Jersey Department of Environmental Protection; NY, New York; PS, public supply; R, recreation; S, storage; H, hydroelectric; AR, artificial recharge; *, usable capacity;**, combined capacity of Canoe Brook reservoirs 1, 2, and 3; --, data not available; , about; MUA, Municipal Utilities Authority;WC, Water Company; WD, Water Department]

\begin{tabular}{|c|c|c|c|c|c|c|c|c|c|c|c|c|}
\hline $\begin{array}{c}\text { Refer- } \\
\text { ence } \\
\text { number } \\
\text { (figure } \\
6 \text { ) }\end{array}$ & $\begin{array}{l}\text { USGS } \\
\text { station } \\
\text { number }\end{array}$ & $\begin{array}{l}\text { NJDEP } \\
\text { water } \\
\text { region }\end{array}$ & Name & Latitude & Longitude & County & Name of river & $\begin{array}{l}\text { Drain- } \\
\text { age } \\
\text { area } \\
\text { (square } \\
\text { miles) }\end{array}$ & $\begin{array}{l}\text { Total } \\
\text { capacity } \\
\text { (billion } \\
\text { gallons) }\end{array}$ & $\begin{array}{l}\text { Date } \\
\text { com- } \\
\text { pleted }\end{array}$ & Use & Owner/Operator \\
\hline 1 & 01376700 & Northeast & De Forest Lake & 410623 & 735801 & Rockland, NY & Hackensack River & 27.5 & 5.7 & 1956 & PS & United Water New Jersey/New York \\
\hline 2 & 01376950 & Northeast & Lake Tappan & 410105 & 740005 & Bergen & Hackensack River & 49.0 & 3.9 & 1966 & $\mathrm{~S}$ & United Water New Jersey \\
\hline 3 & 01377450 & Northeast & Woodcliff Lake & 410100 & 740300 & Bergen & Pascack Brook & 19.4 & .87 & 1905 & $\mathrm{~S}$ & United Water New Jersey \\
\hline 4 & 01378480 & Northeast & Oradell & 405700 & 740200 & Bergen & Hackensack River & 113 & 3.5 & 1922 & PS & United Water New Jersey \\
\hline 5 & 01379990 & Northeast & Splitrock & 405740 & 742745 & Morris & Beaver Brook & 5.50 & 3.3 & 1948 & $\mathrm{~S}$ & Jersey City WD \\
\hline 6 & 01380900 & Northeast & Boonton & 405345 & 742355 & Morris & Rockaway River & 119 & 7.6 & 1904 & PS & Jersey City WD \\
\hline 7 & 01382100 & Northeast & Canistear & 410630 & 742930 & Sussex & Pacock Brook & 5.6 & 2.4 & 1896 & $\mathrm{~S}$ & Newark WD \\
\hline 8 & 01382200 & Northeast & Oak Ridge & 410230 & 743010 & Passaic & Pequannock River & 27.3 & 3.9 & 1880 & $\mathrm{~S}$ & Newark WD \\
\hline 9 & 01382300 & Northeast & Clinton & 410430 & 742700 & Passaic & Clinton Brook & 10.5 & 3.5 & 1889 & $\mathrm{~S}$ & Newark WD \\
\hline 10 & 01382380 & Northeast & Charlotteburg & 410134 & 742530 & Passaic & Pequannock River & 56.2 & 3.0 & 1961 & PS & Newark WD \\
\hline 11 & 01382400 & Northeast & Echo Lake & 410300 & 742430 & Passaic & Macopin River & 4.35 & 1.6 & 1925 & $\mathrm{~S}$ & Newark WD \\
\hline 12 & 01383000 & Northeast & Greenwood Lake & 410936 & 742003 & Passaic & Wanaque River & 27.1 & $6.9 *$ & 1837 & $\mathrm{R}$ & State of New Jersey \\
\hline 13 & 01384002 & Northeast & Monksville & 410720 & 741749 & Passaic & Wanaque River & 40.4 & 7.0 & 1988 & $\mathrm{~S}$ & Wanaque South Project \\
\hline 14 & 01386990 & Northeast & Wanaque & 410242 & 741744 & Passaic & Wanaque River & 90.4 & 29.6 & 1927 & PS & $\begin{array}{l}\text { North Jersey District Water Supply } \\
\text { Commision }\end{array}$ \\
\hline 15 & -- & Northeast & Canoe Brook No. 1 & 404451 & 742102 & Essex & Passaic River & -- & $3.1^{* *}$ & 1900 & PS & New Jersey American WC \\
\hline 16 & -- & Northeast & Canoe Brook No. 2 & 404447 & 742142 & Essex & Passaic River & -- & -- & 1938 & PS & New Jersey American WC \\
\hline 17 & -- & Northeast & Canoe Brook No. 3 & 404724 & 742142 & Essex & Passaic River & -- & -- & 1957 & PS & New Jersey American WC \\
\hline 18 & -- & Northeast & Pines Lake & 405930 & 741606 & Passaic & Haycock Brook & 3.76 & 1.9 & 1927 & $\mathrm{R}$ & Pines Lake Association \\
\hline 19 & 01387860 & Northeast & Point View & 405818 & 741524 & Passaic & Haycock Brook & 1.89 & 2.8 & 1964 & $\mathrm{~S}$ & Passaic Valley Water Commission \\
\hline 20 & -- & Northeast & Kakeout & 405924 & 742159 & Morris & Stonehouse Brook & 5.30 & .955 & 1926 & PS & Butler WD \\
\hline 21 & -- & Northeast & Clyde Potts & 404822 & 743452 & Morris & Harmony Brook & 2.1 & .34 & 1932 & PS & Southeast Morris County MUA \\
\hline 22 & -- & Northeast & Haledon & 405844 & 741145 & Bergen & Molly Ann Brook & 1.55 & .225 & 1926 & PS & Haledon WD \\
\hline 23 & 01396790 & Raritan & Spruce Run & 403837 & 745526 & Hunterdon & Spruce Run & 41.3 & $11.0^{*}$ & 1963 & $\mathrm{~S}, \mathrm{R}$ & New Jersey Water Supply Authority \\
\hline 24 & 01397050 & Raritan & Round Valley & 403639 & 745042 & Hunterdon & Prescott Brook & 5.7 & 55.0 & 1966 & $S, R$ & New Jersey Water Supply Authority \\
\hline 25 & 01405000 & Raritan & Farrington Lake & 402700 & 742705 & Middlesex & Lawrence Brook & 34.4 & .655 & 1927 & S & New Brunswick WD \\
\hline 26 & 01405500 & Raritan & Duhernal & 402424 & 742209 & Middlesex & South River & 94.6 & .138 & 1939 & $\mathrm{AR}$ & Duhernal Water System \\
\hline 27 & & Raritan & Orange & 404607 & 741702 & Essex & $\begin{array}{l}\text { West Branch Rahway } \\
\text { River }\end{array}$ & y 6.3 & .25 & 1883 & PS & Orange WD \\
\hline 28 & 01455221 & Northwest & Merrill Creek & 404342 & 750611 & Warren & Merrill Creek & 3.13 & 16.6 & 1987 & $\mathrm{~S}$ & Merrill Creek Reservoir Project \\
\hline 29 & 01455400 & Northwest & Lake Hopatcong & 405500 & 743950 & Morris & Musconetcong River & 25.3 & $7.5^{*}$ & 1828 & $\mathrm{R}$ & State of New Jersey \\
\hline 30 & -- & Northwest & Lake Mohawk & 410200 & 743842 & Sussex & Wallkill River & 4.38 & 2.3 & 1927 & $\mathrm{R}$ & Lake Mohawk Golf Club \\
\hline 31 & -- & Northwest & Yards Creek & 405954 & 750148 & Warren & Yards Creek & 3.08 & 1.76 & 1965 & $\mathrm{H}$ & GPU Generation Corporation \\
\hline 32 & -- & Northwest & Branchville & 411144 & 744358 & Sussex & Dry Brook & .37 & .150 & 1911 & PS & Branchville WD \\
\hline 33 & 01411878 & Lower Delaware & Union Lake & 392406 & 750318 & Cumberland & Maurice River & 216 & 3.8 & 1867 & $\mathrm{R}$ & State of New Jersey \\
\hline 34 & 01407500 & Atlantic Coastal & Swimming River & 401906 & 740706 & Monmouth & Swimming River & 49.2 & 2.25 & 1901 & PS & New Jersey American WC \\
\hline 35 & 01407965 & Atlantic Coastal & Manasquan & 401048 & 741140 & Monmouth & Timber Swamp Brook & 3.18 & 4.7 & 1990 & PS & New Jersey Water Supply Authority \\
\hline 36 & -- & Atlantic Coastal & Glendola & 401137 & 740523 & Monmouth & Robins Swamp Brook & .34 & 1 & 1962 & PS & New Jersey American WC \\
\hline 37 & -- & Atlantic Coastal & Kuehnle & 392620 & 743300 & Atlantic & Absecon Creek & 8.65 & .250 & $\sim 1910$ & $\mathrm{~S}$ & Atlantic City MUA \\
\hline 38 & -- & Atlantic Coastal & Doughty Pond & 392548 & 743119 & Atlantic & Absecon Creek & 5.85 & .245 & $\sim 1910$ & PS & Atlantic City MUA \\
\hline
\end{tabular}




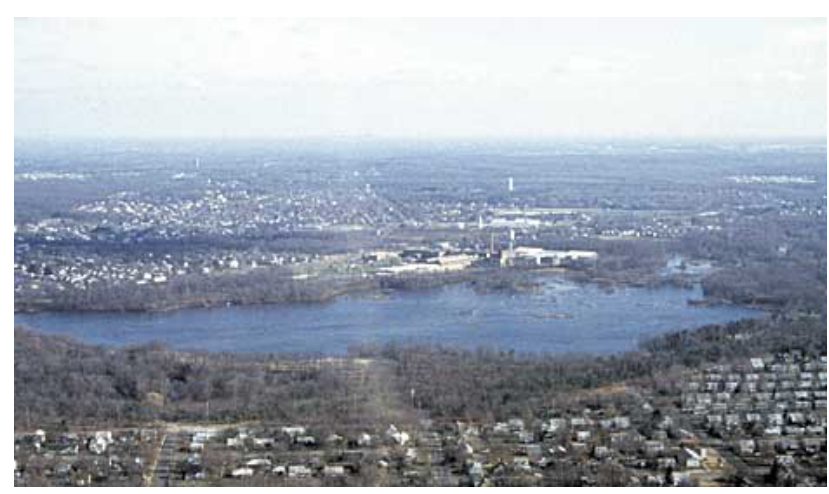

Duhernal Lake in Middlesex County, New Jersey. (File photograph, U.S. Geological Survey, West Trenton, New Jersey)

The State's major canal, the Delaware and Raritan Canal (D and R Canal), was used at one time for navigation but now is used only for transferring water. Water is taken from the Delaware River, moved through the canal and diverted for public supply, and the remainder is discharged to the Raritan River (fig. 6). Other canals in the State are no longer in operation.

The USGS maintains a network of stations in New Jersey for measuring how much water is flowing in the streams (stream discharge) and the height of the water above a selected point (stream stage). These measurements provide data that State and local officials can use in many ways: for flood forecasting; allocating water for municipal use, irrigation, and industries; developing and operating recreation facilities; protecting and maintaining

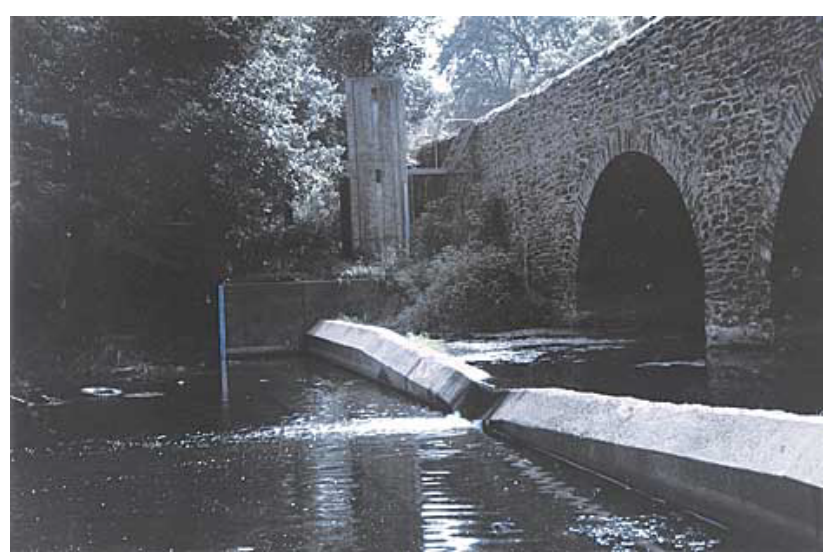

\section{Streamflow-gaging station, Stony Brook at Princeton, New Jersey. (Photograph by Jerry Ludlow)}

aquatic ecosystems; delineating and managing floodplains; designing and operating reservoirs, designing highway bridges and culverts; and scheduling power production (Wahl and others, 1995). The USGS has been gaging (measuring) streamflow in various streams in New Jersey since 1897 (Gillespie and Schopp, 1982). Several stations have been operating since the 1920's or 1930's. The longer the period of record at a given gaging station, the more likely it is that many different hydrologic conditions at that station, such as floods of different magnitudes, or droughts, have been observed. Data collected at long-term stations can provide more accurate information than stations with only a few years of data because seasonal and yearly variations can be averaged over many years. In any given year, the USGS collects daily discharge data at nearly 100 established sites statewide. (See Box A). 


\section{$A$}

\section{Streamflow-gaging station and hydrograph}

Streamflow commonly is measured at a gaging station--a structure on the banks of the stream, or sometimes directly in the stream. The gaging station typically is made of concrete, concrete block, concrete pipe, or steel pipe (diagram A-1). This structure contains a "stilling well," a hole dug into the ground on the bank of the river. The well is lined so that water from the banks of the river cannot enter and no water can seep out. An intake pipe from the stream connects the stilling well to the stream, and water fills the stilling well to the height of the water in the stream. A float device lowered to the surface of the water in the stilling well is used to determine stream stage (the height of the water surface above an established level). The stilling well protects the float from fluctuations caused by wind and turbulence. The float rises and falls with the water level in the stream. A pulley attached to the float is connected to a water-level recorder. The recorder typically is a battery-operated instrument that produces either a punched tape or an electronic record of the rise and fall of the water level in the stream over time. (See Wahl and others, 1995.)

In order to determine discharge from the stage measurements made at the streamflow-gaging station, a stage-discharge relation is developed by making periodic measurements of discharge at the same site. Discharge is equal to the cross-sectional area of the stream multiplied by the velocity of the water. Physical measurements of the velocity of the water and the cross-sectional area of the stream are made by wading the stream with a current meter and wading rod or by measuring from a bridge or cableway. The discharge measurements made over the range in stage of the stream are plotted against the stage that was recorded at the same time to define the stage-discharge relation for the stream at that station. The stage-discharge relation is then used in conjunction with the recorded stage to determine discharge throughout the year (Wahl and others, 1995.)

The relation between stage and discharge is constantly changing as a result of erosion of streambed or banks, deposition of material to streambed or banks, growth of vegetation in the channel or on the banks, snow, or ice. Therefore, establishing a stage-discharge relation is a continual process of making measurements and comparing them to historical measurements to assess change over time.

A hydrograph, or graph showing discharge in units of cubic feet per second at a single location as a function of time, can be used to study long- and short-term changes in the discharge of the stream. The hydrograph can be divided graphically into sections that represent the various components of streamflow, such as ground-water discharge, overland flow, precipitation, and interflow (Fetter, 1980).

A hydrograph of the discharge of the Toms River near Toms River, N.J., during 1978-97, recorded at a streamflow-gaging station, is shown in graph A-2. This is only a small part of the record available for this site, where a gaging station has been operating since October 1928. A few dozen streamflowgaging stations throughout the State have been operating since the early 1920's (R.D. Schopp, U.S. Geological Survey, oral commun., 1998). Other, temporary stations that were installed for specific data-collection purposes may have a period of record that is as short as 1 day. 


\section{A-1.}

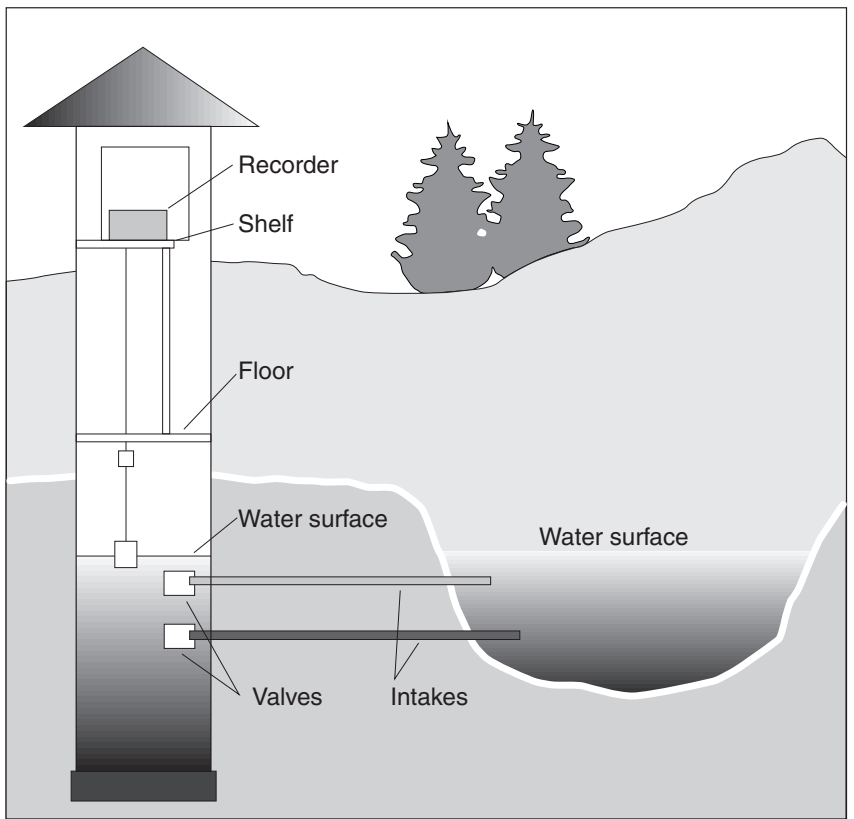

(From Wahl and others, 1995)

\section{A-2.}

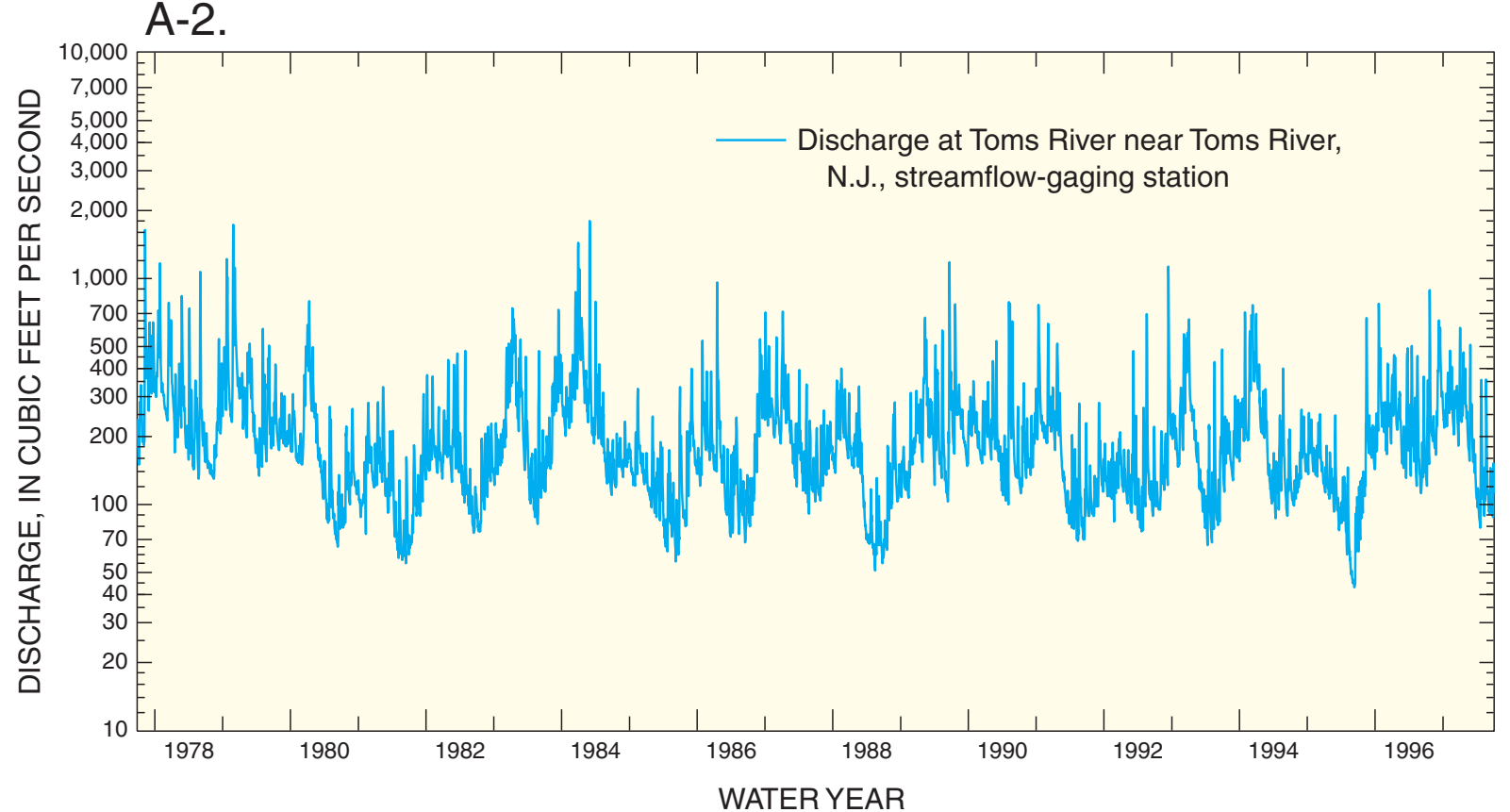

(A-1) Schematic diagram of a typical streamflow-gaging station and (A-2) hydrograph of discharge at the Toms River near Toms River, N.J., streamflow-gaging station, water years 1978-97. Discharge is measured by battery-operated recorder. The hydrograph shows only a portion of the discharge record at this station, which has been in operation since October 1928. 
The topography, land use, and geology within a watershed affects streamflow. Runoff in steep terrain reaches the stream faster than runoff in flatter terrain, where more of the water infiltrates into the ground. Generally, streams in watersheds that are highly developed and have large impervious surface areas such as parking lots, roads, houses, and shopping malls receive significant amounts of overland flow because little water can infiltrate into the ground. Consequently, streams in urban watersheds are likely to have high flow peaks immediately after storms. Urban areas also can have storm sewers that drain directly to streams, allowing stormwater to reach the stream faster. Streams in watersheds that are more rural or undeveloped are likely to experience a more gradual rise in the water level over time, as precipitation that has infiltrated into the ground makes its way slowly to the water table and then through the ground-water system to the stream.

Similarly, the hydrograph of a stream (a line representing stream discharge or stream stage) in an area where bedrock (consolidated rock underlying unconsolidated material) is near or exposed at the land surface area is likely to show steep, high peaks soon after a storm, because the bedrock prevents the rain from infiltrating into the ground. The

hydrograph of a stream in an area where the surficial sediments are sandy is likely to show more gradual, smaller peaks of a longer duration because water can infiltrate the sand easily (fig. 7). In addition, streamflow downstream from reservoirs or regulated lakes typically is more constant than flow in a natural, unregulated stream.

Seasonal differences in watershed conditions also can affect streamflow. During winter, frozen ground can prevent water from infiltrating. In spring, if the ground is already saturated, additional rain will flow directly to the stream as overland flow. In both cases, a streamflow hydrograph will show larger, steeper peaks than are likely to be observed when the ground is neither frozen nor saturated.

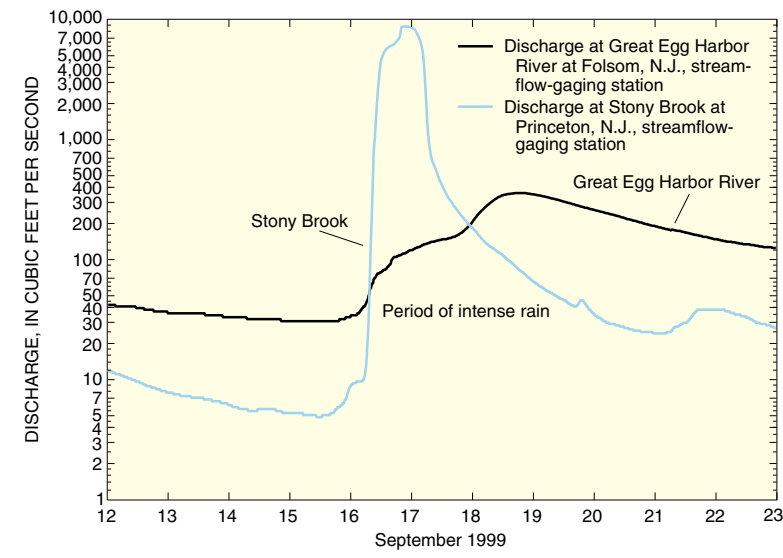

Figure 7. Hydrograph of the discharge of two rivers in New Jersey during Hurricane Floyd, September 16-17, 1999. Between 7.5 and 10 inches of rain fell on the Stony Brook watershed, causing the stream's discharge to peak at about 9,000 cubic feet per second within hours of the heavy rainfall. The Great Egg Harbor River watershed received approximately 5 inches of rain over the same period, but the peak discharge reached only 359 cubic feet per second, roughly 25 times less than the peak discharge of Stony Brook, and occurred about 42 hours after discharge peaked in the Stony Brook watershed. Topography, land use, and geology in the watershed affect the shape of the streamflow hydrograph. The Stony Brook watershed is more developed and has steeper terrain than the Great Egg Harbor River watershed. The geology is bedrock covered by a thin layer of soil. Infiltration is minimal and peaks in streamflow represent overland flow reaching the stream. The storm peak occurs and recedes quickly. The Great Egg Harbor River watershed is less developed and has flatter terrain and sandy soils that allow overland runoff to infiltrate. The river rises more slowly and its hydrograph shows a lower and broader peak flow that occurs later and is of longer duration.

Generally, streams in watersheds that are highly developed and have large impervious surface areas such as parking lots, roads, houses, and shopping malls receive significant amounts of overland flow because little water can infiltrate into the ground. Consequently, streams in urban watersheds are likely to have high flow peaks immediately after storms. 


\section{Ground-water system}

The water that infiltrates through the land surface moves downward through the soil and the unsaturated zone to the water table (fig. 3). The water table is the top of the saturated zone, and rocks and sediments below the water table are saturated. This water is called ground water. Ground water is stored in and flows through layers of consolidated or unconsolidated rocks or sediments called aquifers. Aquifers are geologic units that can store and transmit water at rates sufficient to supply reasonable amounts to wells (Fetter, 1980, p. 92). Consolidated rock consists of mineral particles of various sizes and shapes that have been cemented, fused, or melted together by heat and pressure or chemical reaction. Unconsolidated rock is derived from the physical breakdown (by erosion by running water or freezing and thawing) or chemical decomposition of consolidated rock, and consists of sediments such as gravel, sand, silt, and clay.

Two important properties of aquifers are porosity and permeability. Porosity is a measure of how much water a rock can hold. If a rock is coarsegrained and well-sorted (all the grains are approximately the same size), then the space between the grains accounts for a large percentage of the open space within the rock and the rock can hold a large amount of water. Rock that has many joints and fractures or that has been dissolved by the water flowing through it also can hold large amounts of water. If a rock is poorly sorted (is made up of grains of different sizes), then spaces between the larger grains are filled with smaller grains, resulting in less room for water. Generally, well-sorted rock can hold more water than poorly sorted rock (fig. 8). Permeability is a measure of how well-connected the pore spaces are. A rock with pore spaces that are not connected cannot transmit water, or is not permeable, no matter how great its porosity may be. Aquifers can be composed of sand and gravel, sandstone, limestone that contains fractures, solution cavities, or caverns, or granite that has many joints and fractures.

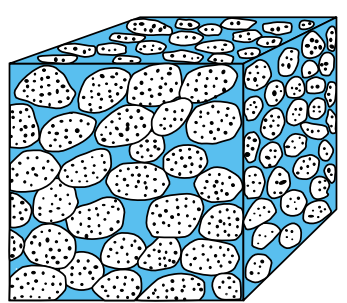

WELL-SORTED SAND
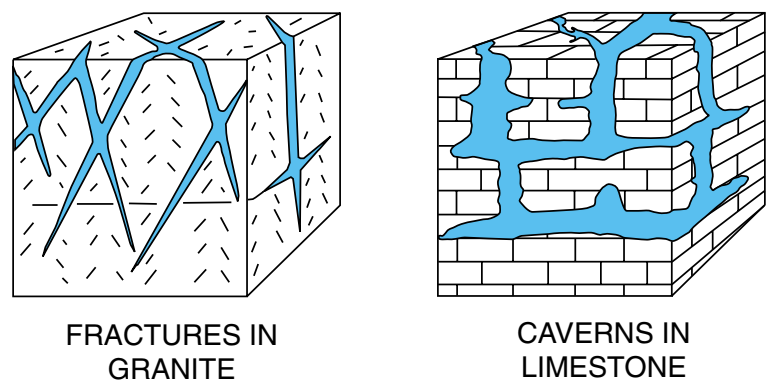

Figure 8. Types of openings in rocks and sediments that are capable of holding water. Well-sorted rocks and sediments, rocks with many fractures, or rocks with large areas that have been dissolved can hold more water than poorly sorted, unfractured, or undissolved rocks (modified from Heath, 1983).

\section{Aquifers are geologic units that can store and transmit water at rates sufficient to supply reasonable amounts to wells.}


Ground water is found in two types of aquifers--confined and unconfined. An unconfined (water-table) aquifer is not overlain by a confining unit. Unconfined aquifers in New Jersey generally are near land surface and are open to the atmosphere, and the water level rises and falls in response to infiltration of precipitation, discharge of ground water and surface water, and climatic events (floods or drought). In contrast, the pore spaces in a confined aquifer are completely filled with water. A confined aquifer is overlain by a confining unit--a layer of lower permeability that impedes the flow of water. These layers typically are composed of small particles (silt or clay) or of rock that contains few or poorly connected fractures.

Water generally enters the ground-water system where aquifers are present at or near land surface (crop out). Water moves in response to the force of gravity and differences in pressure. The combination of these forces is referred to as the hydraulic head. Water that enters the aquifer moves toward a discharge point along pathways that are determined by hydraulic head and permeability. Some water may move, or flow, horizontally through the aquifer, and some may flow vertically through confining layers to an aquifer below. Ground water eventually discharges to surface-water bodies such as streams, lakes, the ocean, or wetlands, or to a well. The time required for ground water to reach the discharge point depends on its flow path. Water that follows a relatively shallow, or local, flow path moves only short distances and may take only days to reach the discharge point, whereas water that follows a deeper, or regional, flow path moves long distances and may take centuries or millennia to reach the discharge point (fig. 9). Water may appear to flow upward at its discharge point as a result of the hydraulic head gradient (horizontal change in hydraulic head in a given direction), which causes water to move continuously from areas of higher hydraulic head (such as below a stream) to areas of lower hydraulic head (such as in a stream). When water is discharged to a stream or a well, it moves "downgradient" (from higher hydraulic head to lower hydraulic head), allowing more water to move in behind it.

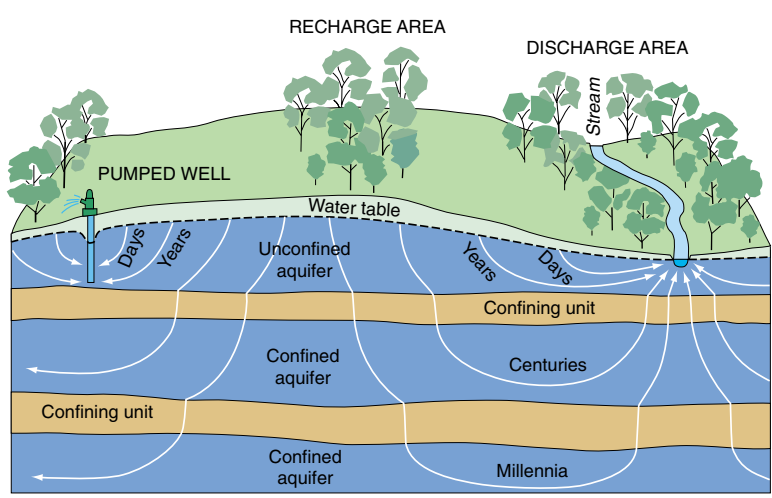

Figure 9. Flow paths of ground water as it moves from recharge areas (hilltops) to discharge areas (streams, lakes, or wells) (modified from Heath, 1983). The length of time it takes the water to move from recharge to discharge point depends on the flow path taken. Water traveling along local flow paths may take days to years to reach its discharge point. Water traveling along regional flow paths may take centuries to millennia. 


\section{In general, chemical characteristics of water differ from place to place and are controlled by temperature, pressure, atmospheric deposition, the duration of contact with rocks and organic matter through or over which the water flows, and by human activities.}

\section{Water quality}

Water that reaches the land surface as precipitation either runs overland toward and into a stream or percolates into the soil. Whatever its route, it comes into contact with a wide variety of materials that can change its chemical composition. Flowing water breaks down rocks, dissolves minerals, picks up sediments, reacts with soil materials and plant and animal matter, and carries the product in solution or suspension (Swenson and Baldwin, 1965). The ability of water to dissolve many substances is determined by its temperature, its $\mathrm{pH}$ (acidity), and its carbon dioxide content, which increases as carbon dioxide is absorbed from air or soil gases (Swenson and Baldwin, 1965). Water that percolates into the soil reacts with soil materials and plant and animal matter, and dissolves minerals in the rocks. The type and concentration of dissolved minerals in the water depends on the type of soil and rock through which it flows and the length of time the two were in contact. Ground water tends to contain higher concentrations of dissolved minerals than surface water because it moves much more slowly--typically on the order of feet per year, as opposed to feet per second for surface water. Also, some rocks are dissolved more easily than others. For example, granite, sandstone, and shale are not very soluble in water, but limestone and marble are more easily dissolved. Water quality also can be altered by soil bacteria, evaporation, and the effects of human activities, which can introduce physical, chemical, and biological contaminants associated with industry, agriculture, and municipal waste into ground and surface waters.

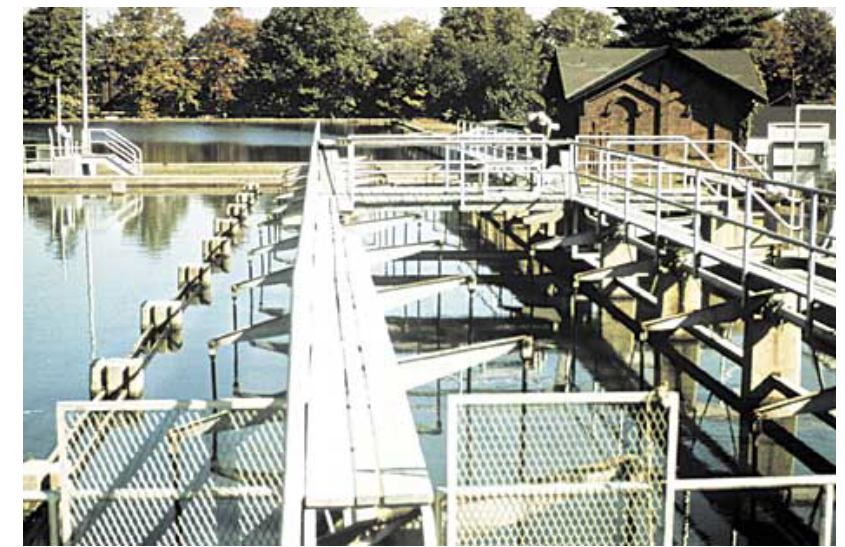

\section{Wastewater treatment plant, New Brunswick, New Jersey (Photograph by Eric Vowinkel)}

Water quality determines the uses for which water is suitable. For example, water that is intended for human consumption generally must be of high quality and must meet Federal and State standards for drinking water (see section on Water-Quality Standards below). Water that contains high concentrations of certain constituents cannot appropriately be used for irrigation because these constituents may interfere with the uptake of nutrients by the plants (Hem, 1985). Water that is not suitable for drinking may be suitable for other applications, such as industrial activities. And water that can be used for some industrial activities--cooling, for example--may not be suitable for others, such as pharmaceutical manufacturing or food processing.

In general, chemical characteristics of water differ from place to place and are controlled by temperature, pressure, atmospheric deposition, the duration of contact with rocks and organic matter through or over which the water flows, and by human activities. 


\section{Water-quality standards}

Water-quality standards are established by Federal and State governments to ensure that water is suitable for its intended use. Standards commonly are specific to water use and differ for ground water, surface water, and marine waters. Water-quality standards are enforced to protect public health and welfare by ensuring the quality of water used for public supply, recreation, agriculture, industry, navigation, and ground-water recharge, and propagation of fish, shellfish, and wildlife (N.J. Department of Environmental Protection, 1996b).

In New Jersey, all surface water is classified according to its designated use: swimming, boating, shellfish harvesting, water supply, maintaining a fish population, and supporting fish reproduction. The Federal Clean Water Act (P.L. 95-217) requires that wherever possible the water-quality standards provide water suitable for fish, shellfish, and wildlife to thrive and reproduce and for people to swim and boat (N.J. Department of Environmental Protection, 1996b). Some classes of waters, such as freshwater streams, are further divided. These can be separated into trout-producing waters, trout-maintenance waters, and non-trout waters. These waters are classified on the basis of trout habitat because the species is a highly desirable game fish and is especially sensitive to temperature changes, habitat, and contaminants (J.G. Kennen, U.S. Geological Survey, oral commun., 1999). Each classification has a corresponding set of water-quality criteria, or numerical concentration values for various constituents, that must be met.

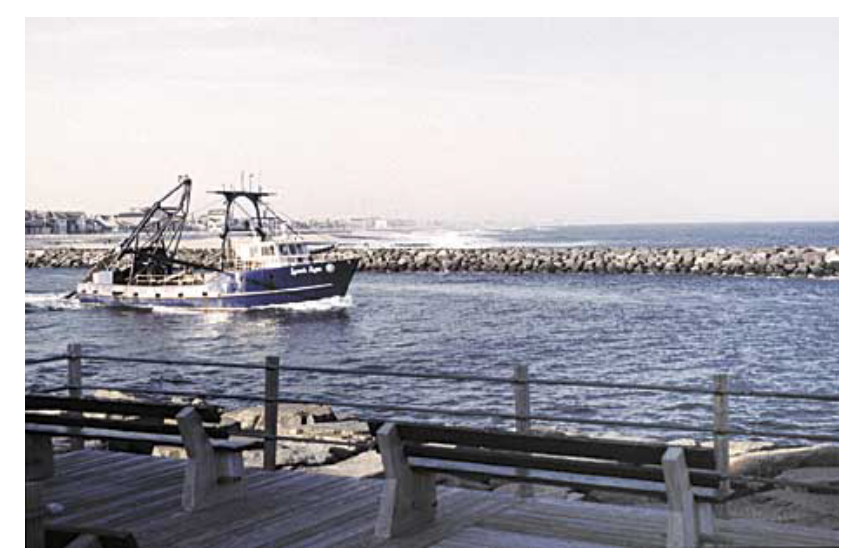

Boating in the Manasquan Inlet. (Photograph by Robert Nicholson)

\footnotetext{
Water-quality standards are enforced to protect public health and welfare by ensuring the quality of water used for public supply, recreation, agriculture, industry, navigation, and ground-water recharge, and propagation of fish, shellfish, and wildlife.
} 
The relation among designated water use, classification, and quality criteria is shown in figure 10. For example, one designated use is primary and secondary recreation (swimming and boating, respectively). Water classifications that must meet this designated use are all freshwater streams (coded FW-1 and FW-2), saline-water estuaries (coded SE1), saline coastal waters (coded SC), and Pinelands waters (coded PL). Each of these classifications, except FW-1, is associated with a specific set of criteria. FW-1 is freshwater that originates in and is wholly within Federal or State parks, forests, fish and wildlife lands, or special holdings. These waters are to be maintained in their natural state and not subjected to any wastewater discharges (N.J. Department of Environmental Protection, 1998b).

The current State ground-water-quality standards were established by NJDEP in January 1993. These standards are intended to protect the integrity of the aquifer for its intended use. As in the approach used for the surface-water-quality standards, designated uses are assigned to the ground-water resources and numerical criteria to support those uses are provided. The designated uses include Class I (waters of ecological significance, such as in the Pinelands areas); Class II (drinking-water supplies); and Class III (waters used for purposes other than drinking, such as industrial cooling). Criteria for Class II waters are based on the protection of human health from exposure to contaminants by consumption of drinking water. The ground-water-quality criteria are used by the NJDEP to regulate groundwater quality by setting standards for discharges to ground water and for ground-water restoration. The ground-water standards also take into account the interaction between ground water and surface water. Because streamflow in many parts of the State is derived mainly from ground water, protection of the ground-water resource is crucial to the maintenance of surface-water quality. (See N.J. Department of Environmental Protection, 1996b.)

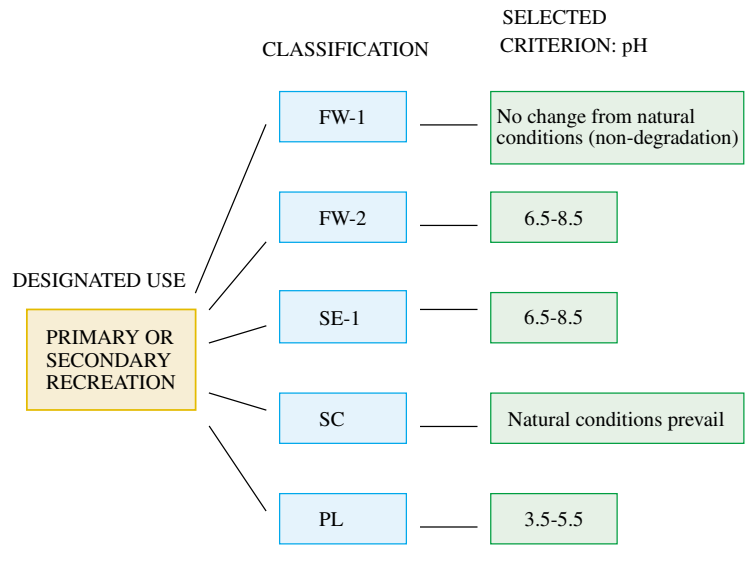

Figure 10. Example of N.J. Department of Environmental Protection water-quality standards, classifications, and criteria. N.J. Department of Environmental Protection water-quality standards are established to protect human health and maintain the integrity of the State's water resources. Standards are made up of a combination of regulations consisting of policy, designated water use, classification, and criteria. Designated water uses include swimming, boating, maintaining fish, supporting fish reproduction, and potable public water supply. Surface-water classifications are freshwater (FW-1, FW-2), saline estuaries (SE-1), saline coastal (SC), and Pinelands (PL). Each classification except FW-1 has a specific set of criteria, or numerical guidelines, that must be met. $\mathrm{pH}$, one of the 138 properties and constituents for which criteria have been established, is shown in the example above. The $\mathrm{pH}$ criteria for $\mathrm{FW}-2$ and $\mathrm{SE}-1$ are the same but the $\mathrm{pH}$ criteria for SC and PL are different. Criteria for other properties and constituents also may vary depending on the classification (N.J. Department of Environmental Protection, 1996a).

\footnotetext{
Because streamflow in many parts of the State is derived mainly from ground water, protection of the ground-water resource is crucial to the maintenance of surface-water quality.
} 
Drinking-water criteria are applied only to water to be used specifically for human consumption and the source of the water may be surface and (or) ground water. Primary drinking-water standards for treated ground and surface waters are the maximum allowable constituent concentrations, called "MCL's" (maximum contaminant levels), which are set to protect human health by limiting concentrations of inorganic chemical contaminants, organic chemical contaminants, microbiologic and radiologic contaminants, and turbidity in public drinking water (table 2). These contaminants may occur naturally or may be derived from domestic and (or) industrial discharges (N.J. Department of Environmental Protection, 1998c). MCL's are based on (1) adverse health effects, (2) availability of instruments to detect the constituent in drinking water, and (3) knowledge that the constituent can occur in drinking water (Susan Lance and Theodore B. Shelton, Rutgers Cooperative Extension, New Jersey Agriculture Experiment Station, New Brunswick, N.J., Fact Sheet 433, accessed July 1, 1999, on the World Wide Web at URL http://www.rce.rutgers.edu/ag/agnaturalresources, text format). Action levels (AL's) are set for lead and copper in public drinking supplies. If an AL is exceeded, the operators of a water system are required to provide corrosion-control treatment, monitor source water for concentrations of lead and copper, replace lead service lines, and notify the public.

Secondary drinking-water standards are set for aesthetic rather than health reasons, and include limits on such water characteristics as offensive taste, odor, corrosivity, and foaming or staining. These standards are recommended but not enforced.

Federal law states that all community public water supplies must be tested on a rigid schedule at specific locations. Private well owners are under no Federal or State regulations to test their own wells, but NJDEP recommends that homeowners arrange for annual testing for bacteria, nitrates, and lead. (See N.J. Department of Environmental Protection, 1994.)

\section{Water use}

In New Jersey, water is used for public, industrial, domestic, and commercial supply, in addition to irrigation, mining, and thermoelectric-power generation. The source of your water depends on where you live, how populated the area is, and what the geology is like. About 73 percent of all water used in New Jersey is surface water and about 27 percent is ground water (Nawyn, 1997). Public supply is the largest use category; in northern New Jersey, about 85 percent of the water used for public supply is surface water and 15 percent is ground water. In southern New Jersey, the percentages are reversed--15 percent is surface water and 85 percent is ground water (J.P. Nawyn, U.S. Geological Survey, written commun., 1999). This is the result of several factors. Northern New Jersey is densely populated, and ground water is concentrated in rock fractures, bedding planes, and solution cavities in the carbonate rocks. Because the ground water is not uniformly distributed, it is less accessible than the ground water in southern New Jersey. In some areas, the quality of the ground water may be unsuitable for particular uses. Reservoirs are heavily used and water-transferring systems are used to transfer water from the more pristine rural areas to urban centers. Southern New Jersey is less densely populated, and aquifers are able to store and produce large amounts of ground water. In addition, well drilling is easier in the unconsolidated sediments of southern New Jersey than in the consolidated rocks of northern New Jersey. 
Table 2. U.S. Environmental Protection Agency and New Jersey State primary and secondary drinking-water standards as of November 1996

[Data from N.J. Department of Environmental Protection, 1997a; MCL, maximum contaminant level; all MCL's are in micrograms per liter ( $\mathrm{g} / \mathrm{L}$ ) which is equivalent to parts per billion (ppb, unless otherwise

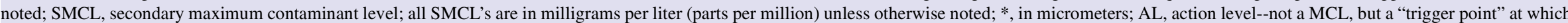

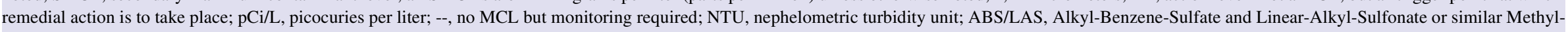
ene Blue Reactive Substances contained in synthetic detergents; >, greater than]

\begin{tabular}{lr}
\hline \multicolumn{1}{c}{ Contaminant } & $\begin{array}{c}\text { Drinking-water } \\
\text { standard }\end{array}$ \\
\hline \multicolumn{1}{c}{ MCL } \\
\hline Volatile Organic Compounds \\
Benzene \\
Carbon tetrachloride & 1 \\
meta-Dichlorobenzene & 2 \\
ortho-Dichlorobenzene & 600 \\
para-Dichlorobenzene & 600 \\
1,1-Dichloroethane & 75 \\
1,2-Dichloroethane & 50 \\
1,1-Dichloroethylene & 2 \\
cis-1,2-Dichloroethylene & 2 \\
trans-1,2-Dichloroethylene & 70 \\
1,2-Dichloropropane & 100 \\
Ethylbenzene & 5 \\
Methyl tertiary butyl ether & 700 \\
Methylene chloride & 70 \\
Monochlorobenzene & 3 \\
Naphthalene & 50 \\
Styrene & 300 \\
1,1,2,2-Tetrachloroethane & 100 \\
Tetrachloroethylene & 1,000 \\
Toluene & 9 \\
1,2,4-Trichlorobenzene & 30 \\
1,1,1-Trichloroethane & 1 \\
1,1,2-Trichloroethane & \\
Trichloroethylene & \\
Vinyl chloride & \\
Xylenes [total] & \\
& \\
& \\
\hline
\end{tabular}

\begin{tabular}{|c|c|}
\hline Contaminant & $\begin{array}{l}\text { Drinking-water } \\
\text { standard }\end{array}$ \\
\hline \multicolumn{2}{|c|}{ MCL--Continued } \\
\hline \multicolumn{2}{|c|}{ Inorganic Contaminants } \\
\hline Antimony & 6 \\
\hline Arsenic & 50 \\
\hline Asbestos $\left[7 \times 10^{6}\right.$ fibers/liter $]$ & $>10 *$ \\
\hline Barium & 2,000 \\
\hline Beryllium & 4 \\
\hline Cadmium & 5 \\
\hline Chromium & 100 \\
\hline Copper & $1,300[\mathrm{AL}]$ \\
\hline Cyanide & 200 \\
\hline Fluoride & 4,000 \\
\hline Lead & $15[\mathrm{AL}]$ \\
\hline Mercury & 2 \\
\hline Nickel & -- \\
\hline Nitrate [as nitrogen] & 10,000 \\
\hline Nitrite & 1,000 \\
\hline Nitrate plus nitrite & 10,000 \\
\hline Selenium & 50 \\
\hline Thallium & 2 \\
\hline \multicolumn{2}{|l|}{ Synthetic Organic Compounds } \\
\hline Alachlor & 2 \\
\hline Aldicarb & -- \\
\hline Aldicarb sulfone & -- \\
\hline Aldicarb sulfoxide & -- \\
\hline Atrazine & 3 \\
\hline Benzo[a]pyrene & .2 \\
\hline Carbofuran & 40 \\
\hline
\end{tabular}

\begin{tabular}{|c|c|}
\hline Contaminant & $\begin{array}{c}\text { Drinking-water } \\
\text { standard }\end{array}$ \\
\hline \multicolumn{2}{|l|}{ MCL--Continued } \\
\hline \multicolumn{2}{|l|}{ Synthetic Organic Compounds--Continued } \\
\hline Chlorodane & 0.5 \\
\hline Dalapon & 200 \\
\hline Dibromochloropropane [DBCP] & .2 \\
\hline Di[2-ethylhexyl]adipate & 400 \\
\hline Di[2-ethylhexyl]phthalate & 6 \\
\hline Dinoseb & 7 \\
\hline Diquat & 20 \\
\hline Endothall & 100 \\
\hline Endrin & 2 \\
\hline Ethylene dibromide [EDB] & .05 \\
\hline Glyphosate & 700 \\
\hline Heptachlor & .4 \\
\hline Heptachlor epoxide & .2 \\
\hline Hexachlorobenzene & 1 \\
\hline Hexachlorocyclopentadiene & 50 \\
\hline Lindane & .2 \\
\hline Methoxychlor & 40 \\
\hline Oxamyl & 200 \\
\hline Polychlorinated biphenyls [PCB's] & .5 \\
\hline Pentachlorophenol & 1 \\
\hline Picloram & 500 \\
\hline Simazine & 4 \\
\hline Toxaphene & 3 \\
\hline 2,3,7,8-TCDD [Dioxin] & $3 \times 10^{-5}$ \\
\hline 2,4-D & 70 \\
\hline 2,4,5-TP [Silvex] & 50 \\
\hline
\end{tabular}


Table 2. U.S. Environmental Protection Agency and New Jersey State primary and secondary drinking-water standards as of November 1996--Continued

\begin{tabular}{|c|c|c|c|c|c|}
\hline Contaminant & $\begin{array}{l}\text { Drinking-water } \\
\text { standard }\end{array}$ & Contaminant & $\begin{array}{l}\text { Drinking-water } \\
\text { standard }\end{array}$ & Contaminant & $\begin{array}{l}\text { Drinking-water } \\
\text { standard }\end{array}$ \\
\hline \multicolumn{2}{|l|}{ MCL--Continued } & \multicolumn{2}{|c|}{ SMCL } & \multicolumn{2}{|c|}{ SMCL--Continued } \\
\hline \multicolumn{2}{|l|}{ Additional Contaminants } & \multicolumn{2}{|l|}{ Physical Characteristics } & Chemical Characteristics & \\
\hline \multirow{4}{*}{$\begin{array}{l}\text { Trihalomethanes--Total of dichloro- } \\
\text { bromomethane, chlorodibro- } \\
\text { momethane, bromoform, and } \\
\text { chloroform }\end{array}$} & \multirow[t]{4}{*}{$\begin{array}{l}100 \mathrm{~g} / \mathrm{L}[\mathrm{ppb}] \\
\text { annual average }\end{array}$} & \multirow{3}{*}{$\begin{array}{l}\text { Color } \\
\mathrm{pH}\end{array}$} & $\begin{array}{l}10 \text { color units (stan- } \\
\text { dard cobalt scale) }\end{array}$ & \multirow{2}{*}{$\begin{array}{l}\text { ABS/LAS (foaming agent) } \\
\text { Aluminum }\end{array}$} & \\
\hline & & & 6.5 to 8.5 & & $\begin{array}{r}0.5 \\
.2\end{array}$ \\
\hline & & & (optimum range) & Chloride & 250 \\
\hline & & \multirow[t]{2}{*}{ Odor } & \multirow{2}{*}{$\begin{array}{l}3 \text { (threshold odor } \\
\text { number) }\end{array}$} & Dissolved solids & 500 \\
\hline \multicolumn{2}{|l|}{ Radionuclides } & & & Fluoride & 2 \\
\hline Radium-226 + radium-228 & $5 \mathrm{pCi} / \mathrm{L}$ & Taste & $\begin{array}{l}\text { No objectionable } \\
\text { taste }\end{array}$ & Hardness $\left(\right.$ as $\mathrm{CaCO}_{3}$ ) & 250 \\
\hline \multirow{3}{*}{$\begin{array}{l}\text { Gross alpha-particle activity } \\
\text { [including radium- } 226 \text { but } \\
\text { excluding radon and uranium] }\end{array}$} & \multirow[t]{2}{*}{$15 \mathrm{pCi} / \mathrm{L}$} & \multirow[t]{3}{*}{ Turbidity (in NTU) } & \multirow{3}{*}{$\begin{array}{l}\text { No more than } 5 \text { per- } \\
\text { cent of the samples } \\
\text { may exceed } 0.5 \\
\text { NTU, nor any sam- } \\
\text { ple exceed } 5 \text { NTU }\end{array}$} & $\begin{array}{l}\text { Iron } \\
\text { Manganese }\end{array}$ & $\begin{array}{l}.3 \\
.05\end{array}$ \\
\hline & & & & Silver & .1 \\
\hline & & & & Sodium & 50 \\
\hline \multirow{2}{*}{$\begin{array}{l}\text { Coliform bacteria (sample amount } \\
\text { depends on size of public-supply } \\
\text { system) }\end{array}$} & \multirow[b]{3}{*}{$\begin{array}{l}\text { coliform no greater } \\
\text { than } 5 \text { percent of } \\
\text { sample }\end{array}$} & & & Sulfate & 250 \\
\hline & & & & \multirow[t]{3}{*}{ Zinc } & \multirow[t]{3}{*}{5} \\
\hline 40 samples per month or more & & & & & \\
\hline less than 40 samples per month & $\begin{array}{l}\text { no more positive } \\
\text { than one sample for } \\
\text { coliform }\end{array}$ & & & & \\
\hline
\end{tabular}




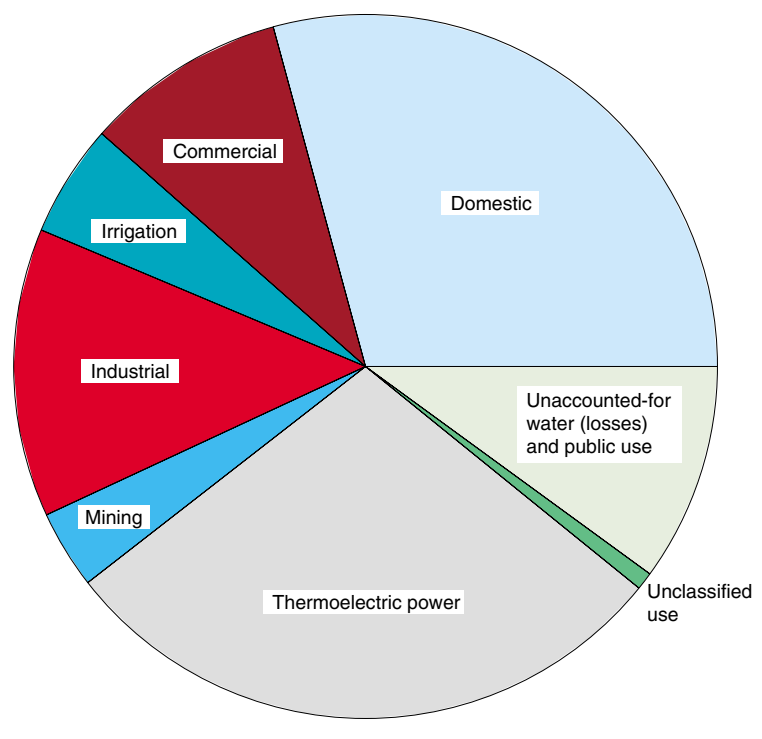

Figure 11. Water used in New Jersey in 1994, by use category. Domestic use includes publicly supplied water and water from wells. Publicly supplied water can be from ground-water or surface-water sources. Commercial, industrial, and thermoelectric uses are made up of publicly supplied water and self-supplied ground and surface water. Water used for mining and irrigation is only self-supplied ground and surface water. Domestic and thermoelectric use are the largest use categories, followed by industrial and unaccounted-for water (losses) and public use. Unaccounted-for water includes leaks to water systems, improperly running meters, and unauthorized hookups. Public uses include water used for fire protection and water used in parks, offices, and schools. (Data from Nawyn, 1997)
Water use in New Jersey by category is shown in figure 11. Domestic supply includes public water supply from both ground-water and surface-water sources, and water used in rural homes with wells (ground water only). Thermoelectric-power generation and domestic supply are the largest categories of use and together account for almost 60 percent of the water used in New Jersey. They are followed by industrial use, unaccounted-for water (losses) and public use, and commercial use. Unaccounted-for water includes leaks to water systems, unauthorized connections, and improperly running meters. Public use is water used in parks, schools, and offices and for fire protection (Nawyn, 1997). Irrigation and mining are the smallest use categories. Water for these uses is derived only from surface water and self-supplied ground water. Water used for all other purposes is self-supplied ground water, surface water, or publicly supplied water.

Ground- and surface-water withdrawals in New Jersey by water region are shown in figure 12 . Total water use is divided into ground-water and surface-water components of public-supply and "other" uses, which include commercial, irrigation, thermoelectric-power generation, mining, and industrial uses. 


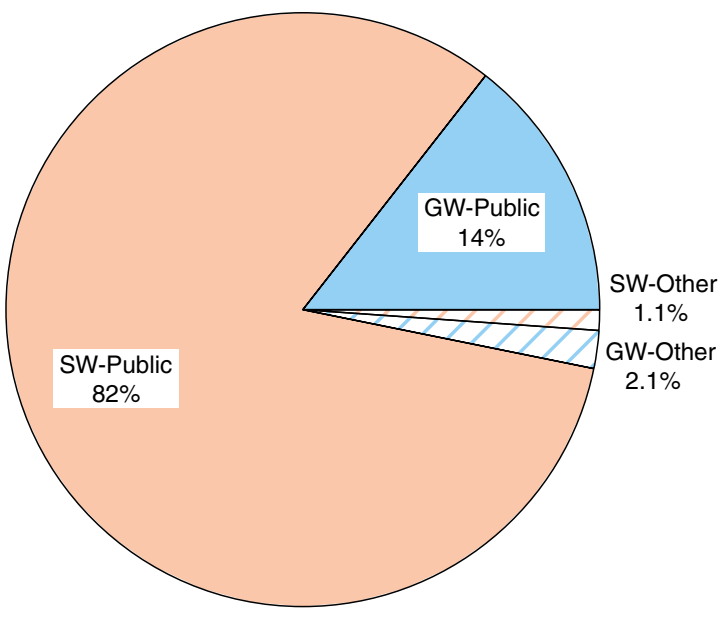

Northeast

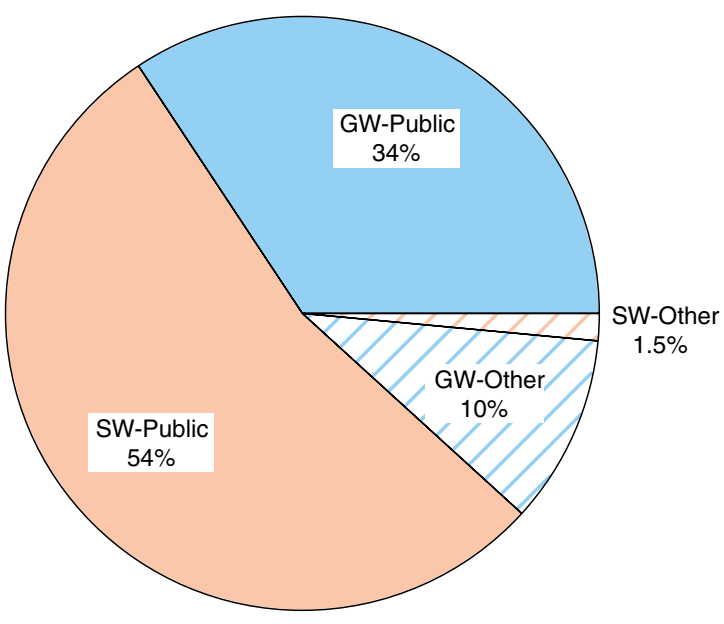

Raritan

Figure 12. Ground-water (GW) and surface-water (SW) withdrawals in the five water regions of New Jersey. Withdrawals are divided into public supply and "other," which includes irrigation, commercial, mining, thermoelectric-power, and industrial withdrawals. The Northeast and Raritan water regions are dominated by public-supply withdrawals from both ground and surface water. The Lower Delaware water region is dominated by withdrawals for thermoelectric-power generation. In the Northwest water region, large amounts of surface water are withdrawn for public supply from the Delaware River and routed to the Delaware and Raritan Canal to supply the population in other water regions. Additional water is withdrawn from the Delaware River for thermoelectric-power generation and industrial use, which make up the "surface-water other" category. In the Atlantic Coastal water region, ground water used for public supply and surface water used for irrigation and industry are the largest withdrawal categories.

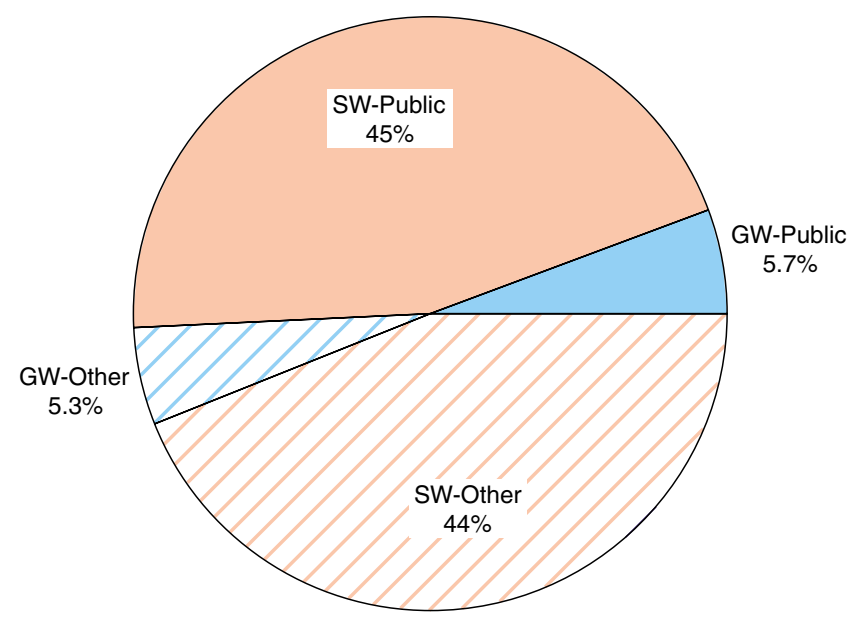

Northwest

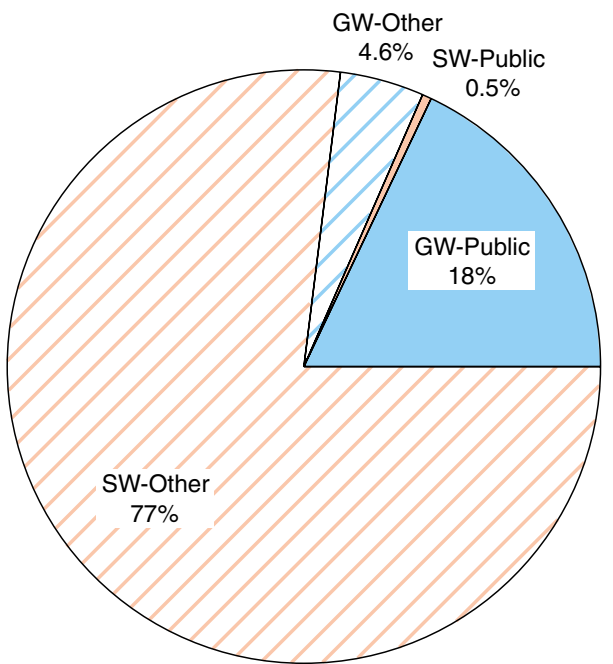

\section{Lower Delaware}

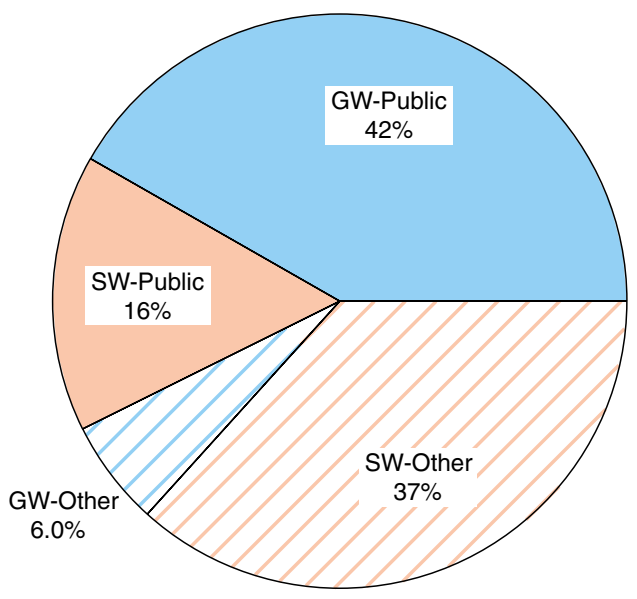

Atlantic Coastal 
Public supply use is most prevalent in the Northeast and Raritan water regions. Large amounts of surface water are withdrawn from the Delaware River in the Northwest water region but not used by the population in the water region. This water is transported through the D and R Canal to other water regions. The large "other" surface-water component in the Northwest water region consists of withdrawals for industrial use and thermoelectric-power generation. Water use in the Lower Delaware water region is dominated by thermoelectric-power generation, which appears in the surface-water "other" category. This water is withdrawn from the Delaware River and used in power plants for cooling. In the Atlantic Coastal water region, ground water used for public supply predominates, although surface-water withdrawals in the "other" category, largely for irrigation and industry, also are a large component.
An important factor when considering water use is consumptive use. Consumptive use is that part of water withdrawn that is evaporated, transpired, incorporated into products or crops, consumed by people or livestock, or otherwise removed from the immediate environment (Solley and others, 1998). The percentage of total water use that becomes consumptive use depends on what the water is used for and how it is treated after use. For example, of the water withdrawn for public supply or domestic supply, only 18 percent is consumed. The rest is returned to the ground-water or surface-water system. This 18 percent will become 100-percent consumptive if the water used is sent to a sewage-treatment plant that discharges treated water directly to the ocean. Water withdrawn for industrial, mining, and thermoelectric-power generation purposes are 8 percent, 10 percent, and virtually non-consumptive, respectively. The consumptive-use value is important because the largest water-use categories (public supply and thermoelectric-power generation) are not the largest consumptive users. Irrigation, on the other hand, is one of the smallest water-use categories in New Jersey, but most irrigation water use is consumptive. Water withdrawn for irrigation is 90-percent consumptive because of evaporation and the uptake by the plants; therefore, very little water is returned to the system. 


\section{DESCRIPTION OF THE STUDY AREA}

New Jersey can be divided into five water regions--the Northeast, Raritan, Northwest, Lower Delaware, and Atlantic Coastal water regions. The five water regions are divided into 20 watershedmanagement areas, which are subdivided into more than 100 individual watersheds (figs. 1 and 2a-e). These management categories were established by the NJDEP in January 1997 to facilitate the use of a "watershed-management approach" to managing and protecting New Jersey's water resources.

\section{Geology and hydrology}

New Jersey can be divided geologically into northern and southern parts by the Fall Line. North of the Fall Line are the Valley and Ridge, New England (also called the Highlands), and Piedmont Physiographic Provinces. South of the Fall Line is the Coastal Plain Physiographic Province (fig. 13). The Fall Line roughly parallels U.S. Route 1 from Trenton to New York City and is marked by a series of waterfalls along river courses. The Fall Line also is the boundary between older, resistant consolidated rocks to the northwest and younger, weaker, unconsolidated sediments to the southeast. Each physiographic province has distinct geologic and hydrologic characteristics. Because the hydrologic characteristics of aquifers and confining units are defined by geologic properties such as grain

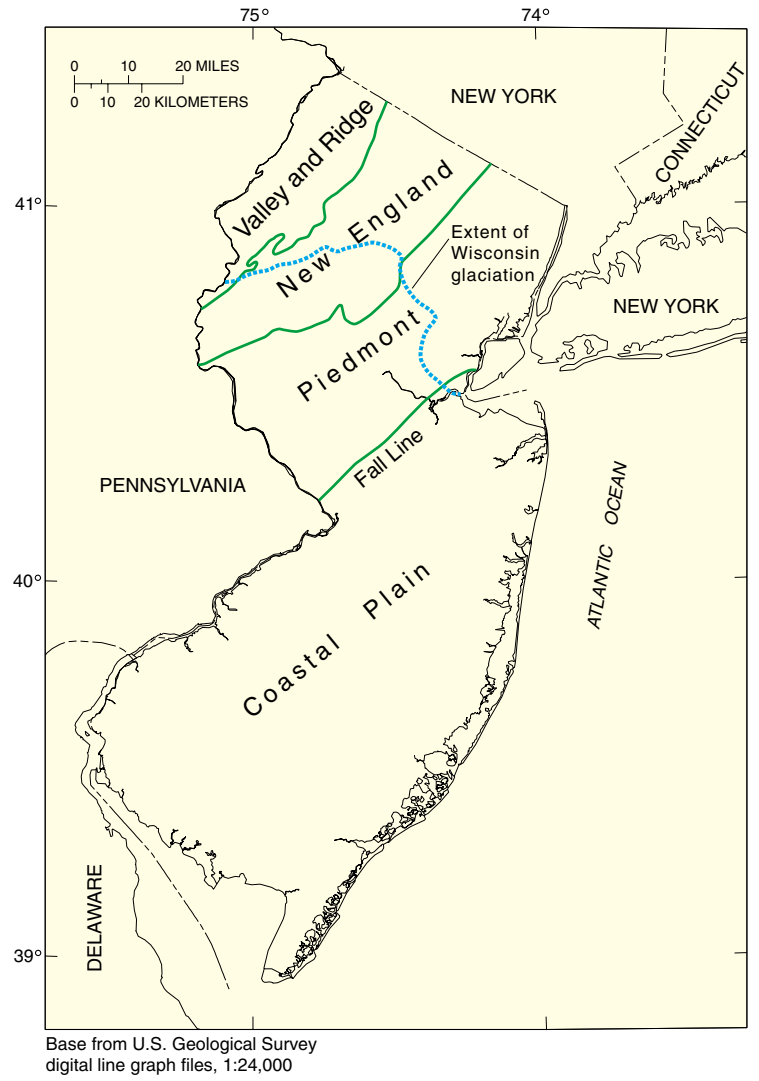

Figure 13. New Jersey spans parts of four physiographic provinces. Aquifers in the northern three physiographic provinces are composed of glacial valley-fill deposits and fractured shales, limestones, sandstones, conglomerates, and crystalline rock. Aquifers in the Coastal Plain consist of unconsolidated sands and gravel.

\section{New Jersey can be divided into five water regions-- the Northeast, Raritan, Northwest, Lower Delaware, and Atlantic Coastal water regions.}

New Jersey can be divided geologically into northern and southern parts by the Fall Line. North of the Fall Line are the Valley and Ridge, New England (also called the Highlands), and Piedmont Physiographic Provinces. South of the Fall Line is the Coastal Plain Physiographic Province. 


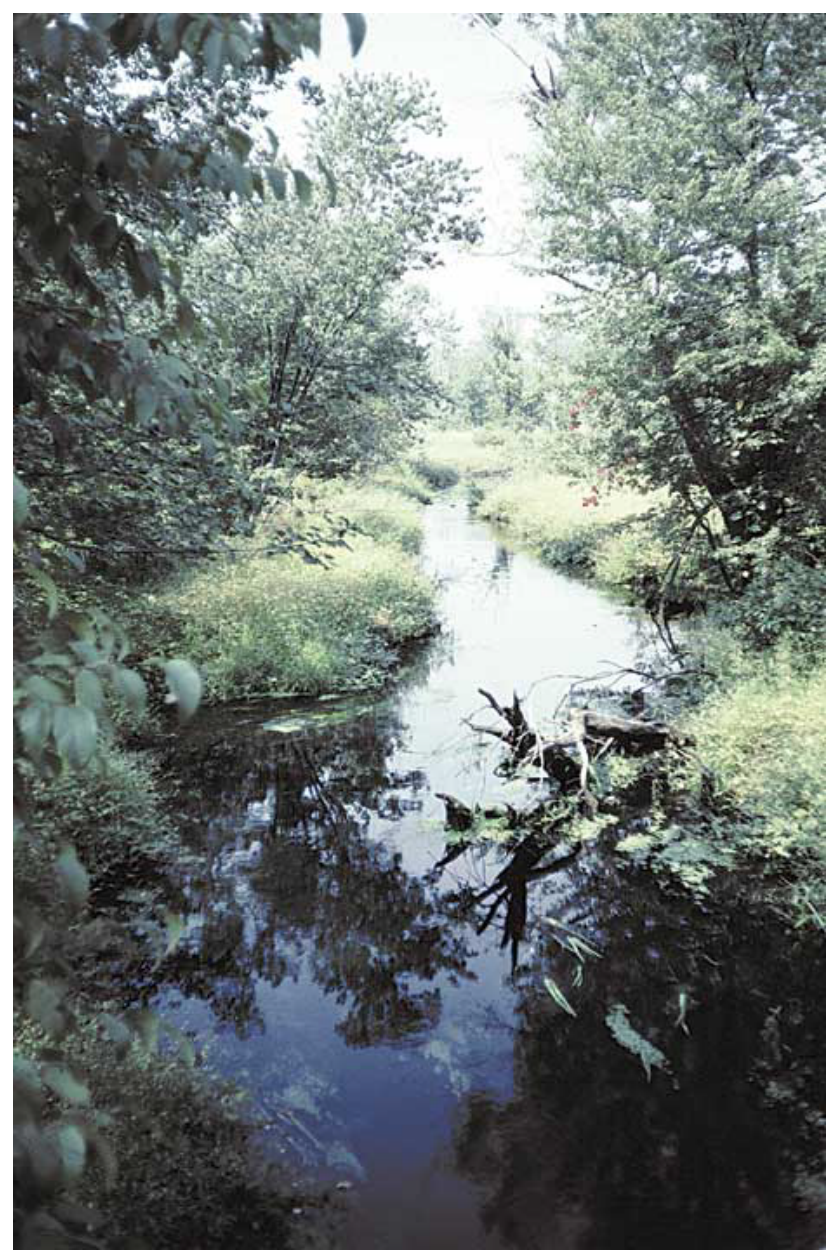

Springers Brook near Indian Mills, New Jersey. (Photograph by Robert Nicholson)

size, sorting, and resistance to erosion and fracturing, geology exerts considerable control over ground-water hydrology. North of the Fall Line, aquifers and confining units are composed of glacial valley-fill deposits, fractured shale, limestone, sandstone, conglomerate, and crystalline-rock units; south of the Fall Line, they consist of unconsolidated gravels, sands, and clays.

Geology also controls stream characteristics to a large extent. Streams in the physiographic provinces north of the Fall Line, such as West Brook near Wanaque, New Jersey, tend to have steep gradients with rocky bottom material, whereas those in the Coastal Plain Physiographic Province, such as Springers Brook near Indian Mills, New Jersey, are characterized by sandier streambeds and gentler slopes. Rocky bottom material tends to impede

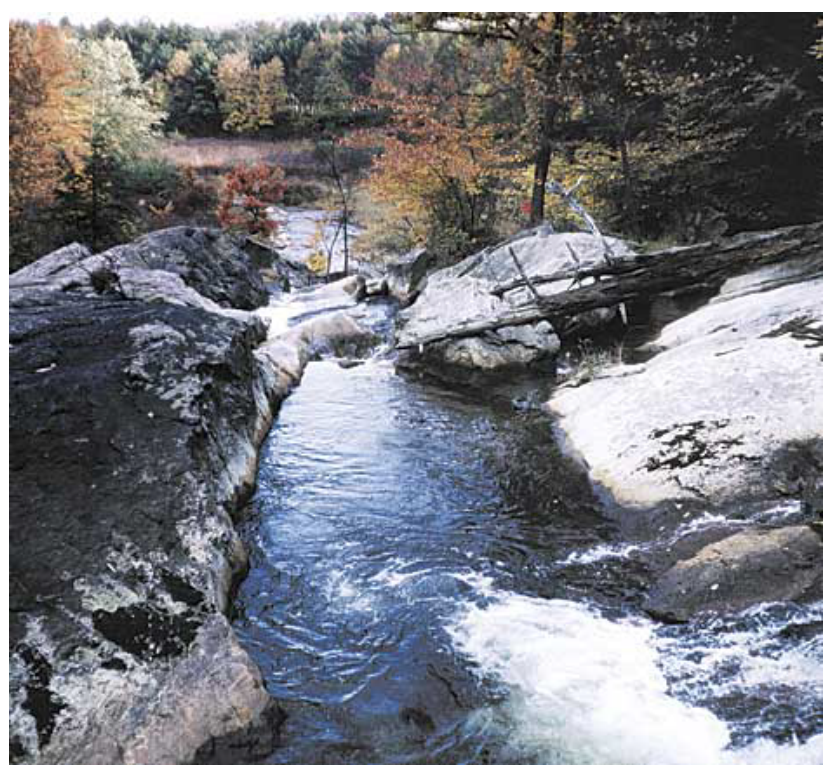

\section{West Brook near Wanaque, New Jersey. (Photographer unknown)}

streamflow as a result of friction between the water and the stream channel. Stream velocity tends to be greater in steep channels than in those with gentler slopes.

The interaction of water, wind, temperature, and pressure with rocks and sediments is a degenerative geologic process called weathering. Plants also contribute to weathering by helping to break down the rocks and sediments. Weathered rock material is the basic ingredient of soils (Keller, 1979, p. 51). (See Box B.)

As glaciers moved into New Jersey from New York State, they picked up and transported rocks and sediment. The northern physiographic provinces were covered by glaciers several times; the last glaciers receded about 20,000 years ago. The "Wisconsinan" glacier left behind deposits of "glacial drift" and "till." The degree of sorting of a glacial drift determines its water-holding and -transmitting properties. Drift that is not well-sorted and contains large amounts of fine-grained material such as silt and clay acts as a confining unit. Drift that is well-sorted and contains predominantly layers of sand and gravel is called "stratified drift" and makes an excellent aquifer. "Till" is a mix of unsorted clay, silt, sand, gravel, and boulders. In upland areas till is generally 30 to $40 \mathrm{ft}$ (feet) thick, but in the valleys and lowlands, 


\section{$B$}

\section{Soils and their relation to the hydrologic system}

Soils, together with climate, geology, and topography, determine the hydrologic characteristics of a watershed (Ayers and others, 1994). Soils influence the amount of and speed with which water infiltrates into the ground. Sandy soils allow more water to infiltrate, and at a faster rate, than clayey soils. Clayey soils tend to cause pooling of precipitation on the land surface, resulting in overland flow. Clayey soils also tend to retain rather than transmit water. The amount of water that is retained in the soil affects its ability to sustain plant growth, and minerals in the soil can be dissolved and affect the quality of the water moving through it.

The Natural Resources Conservation Service (NRCS) conducts soil surveys and produces maps that show the location and extent of soils in an area. Shown is an example of a soil map of part of Morris County, N.J. Soil surveys provide information on the physical and chemical properties of the soils that is needed by community planners, engineers, scientists, and farmers. Soil surveys are the basis for predicting the behavior of soil under alternative uses, its potential for erosion, the degree to which it will allow contaminated water from the land surface to infiltrate and recharge the water table, and its suitability for cultivating crops, trees, and grasses (National Resources Conservation Service, U.S. Department of Agriculture, unpub. data accessed January 13, 1999, on the World Wide Web at URL http://www.nrcs.usda.gov/NRCSprog.html, text format). 


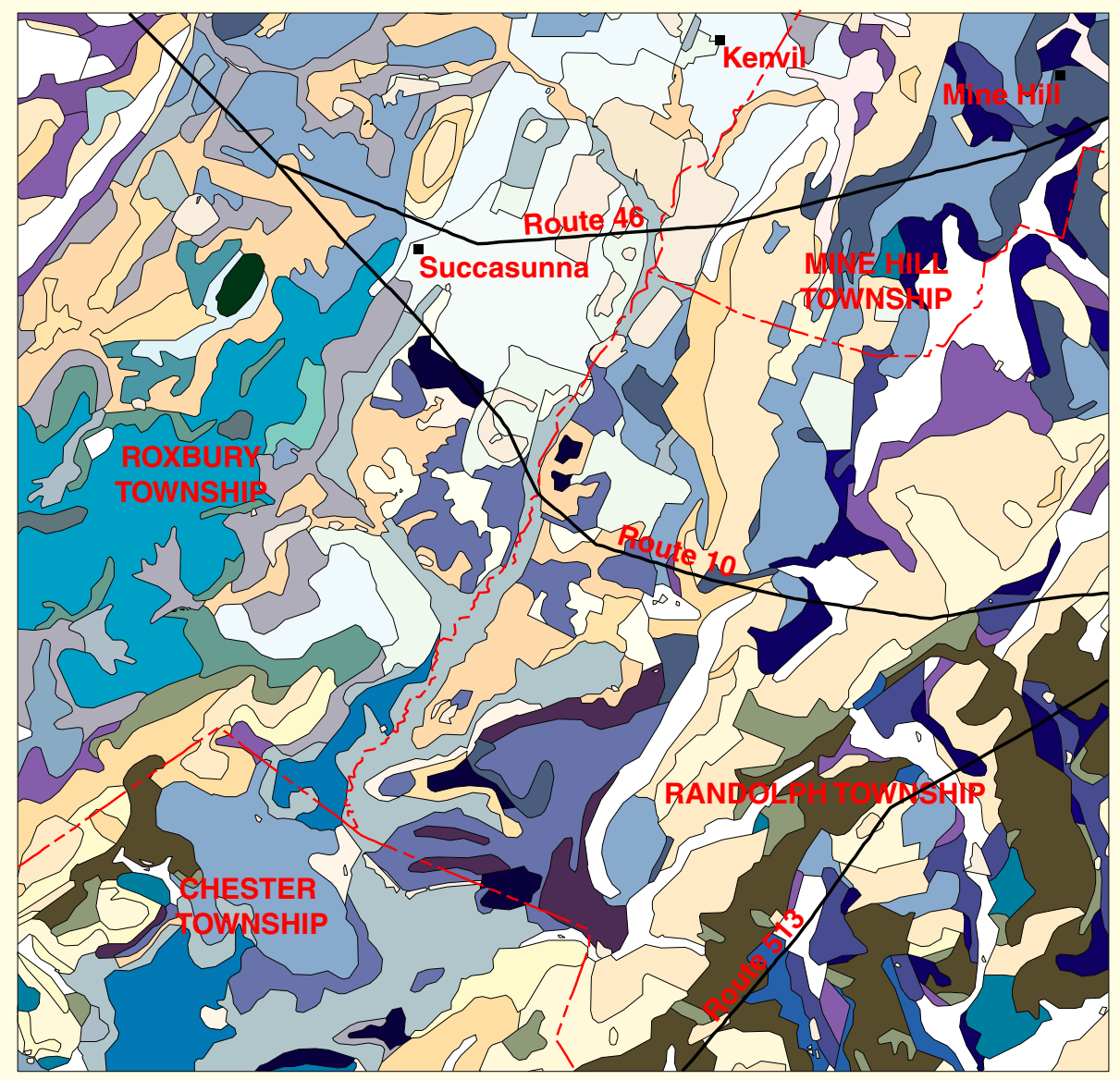

EXPLANATION

Adrian muck

Annandale gravelly loam, 3 to 8 percent slopes

Annandale gravelly loam, 8 to 15 percent slopes

Bartley loam, 3 to 8 percent slopes

Bartley loam, 8 to 15 percent slopes

Bartley gravelly loam, 8 to 15 percent slopes

Biddeford silt loam

Boonton and Haledon extremely stony soils, 8 to 15 percent slopes

Carlisle muck

Cokesbury gravelly loam, 0 to 3 percent slopes

Edneyville gravelly loam, 3 to 8 percent slopes

Edneyville gravelly loam, 8 to 15 percent slopes

Hibernia stony loam, 3 to 15 percent slopes

Made land

Muck, shallow over clay

Natcong gravelly sandy loam, 3 to 8 percent slopes

Natcong gravelly sandy loam, 8 to 15 percent slopes

Otisville gravelly loamy sand, 3 to 15 percent slopes

Parker gravelly sandy loam, 3 to 15 percent slopes

Parker very gravelly sandy loam, 15 to 25 percent slopes

Parker-Edneyville extremely stony sandy loam, 3 to 15 percent slopes

Parker-Edneyville extremely stony sandy loam, 15 to 25 percent slopes

Parker-Rock outcrop complex, 20 to 35 percent slopes

Example soils map of a part of Morris County, New Jersey 
deposits of sand and gravel can be as much as $350 \mathrm{ft}$ thick (U.S. Geological Survey, 1985) (fig. 14). Stratified sand and gravel deposits can be highly productive aquifers and may yield more than 2,000 gal $/ \mathrm{min}$ (gallons per minute) to a well (table 3). Wells that are completed in these aquifers typically are used for public and industrial supply (U.S. Geological Survey, 1985).

The part of the Valley and Ridge Physiographic Province that lies within New Jersey is located in the northwesternmost part of the State and is totally encompassed by the Northwest water region (fig. 13). This area is characterized by long, parallel, northeast-southwest-trending ridges and valleys that generally are formed by erosion-resistant sandstone and shale and easily eroded limestone, respectively. In this area, the carbonate rocks (limestones) are the most productive aquifers, especially where they are covered by glacial deposits (U.S. Geological Survey, 1985). Solution channels and cavities in the limestones can hold and transmit large amounts of water. The sandstones and the shales may or may not be productive, depending on the amount of weathering and fracturing they have undergone.

The part of the New England (Highlands) Physiographic Province that lies within New Jersey covers parts of the Northwest, Northeast, and Raritan water regions (fig. 13). This province contains the oldest rocks in New Jersey. The sedimentary rocks deposited in this province were subjected to high heat and pressure, were intensely deformed, and have recrystallized into granites, gneisses, and a small amount of marble. The granite and gneisses are resistant to erosion and generally are poor aquifers except where they are weathered and fractured. Some valleys in this province are underlain by carbonate rocks that can be highly productive aquifers. Glacial deposits in this area also are productive aquifers.

The part of the Piedmont Physiographic Province that lies within New Jersey covers parts of the Northwest, Northeast, and Raritan water regions (fig. 13). In New Jersey, the Piedmont is separated from the New England Physiographic Province by major faults. The Piedmont is characterized by interbedded sandstone, shale, conglomerate, basalt, and diabase (fig. 14). Water is found in the joints and fractures of the shales and sandstones, typically in the upper 200 to $300 \mathrm{ft}$. Coarse-grained sandstones also hold water in the pore spaces between the sand grains. The aquifers in this area can yield as much as $1,500 \mathrm{gal} / \mathrm{min}$ to wells (table 3 ).

The part of the Coastal Plain Physiographic Province that lies within New Jersey, covers about 4,200 $\mathrm{mi}^{2}$ (fig. 13) and encompasses the Atlantic Coastal and Lower Delaware water regions, as well as the southernmost parts of the Northwest and Raritan water regions. The Coastal Plain is characterized by a seaward-thickening wedge of unconsolidated sediments that starts as a featheredge at the Fall Line and reaches a thickness of about 6,500 ft in southern Cape May County (Zapecza, 1989). The sediments are composed of alternating layers of clay, silt, sand, and gravel; the layers of sand and gravel are aquifers and the layers composed predominantly of silts and clays are confining units (fig. 14). Five principal aquifers underlie the Coastal Plain: the KirkwoodCohansey aquifer system, the Atlantic City 800-foot sand, the Wenonah-Mount Laurel aquifer, the Englishtown aquifer system, and the Potomac-Raritan-Magothy aquifer system (table 3 ). The Kirkwood-Cohansey aquifer system is unconfined; the other aquifers are confined except where they reach the surface or are overlain by permeable surficial deposits (U.S. Geological Survey, 1985). The Kirkwood-Cohansey aquifer system underlies $3,000 \mathrm{mi}^{2}$ of the Coastal Plain. The sands and gravels of this aquifer system make it an excellent source of water and well yields can be as high as 1,500 gal/min. Streams and other surface-water features generally are in good hydraulic connection with the KirkwoodCohansey aquifer system, making it an important component of watershed management in the Coastal Plain. The Potomac-Raritan-Magothy aquifer system is the most productive aquifer system and the most extensively used confined aquifer system in the Coastal Plain in New Jersey (U.S. Geological Survey, 1985). It is found throughout the Coastal Plain but is used most heavily along the Delaware River from Mercer County to Salem County and along the Raritan Bay in Middlesex County. Withdrawal rates from individual wells in this aquifer are as high as 2,000 gal/min (table 3). 


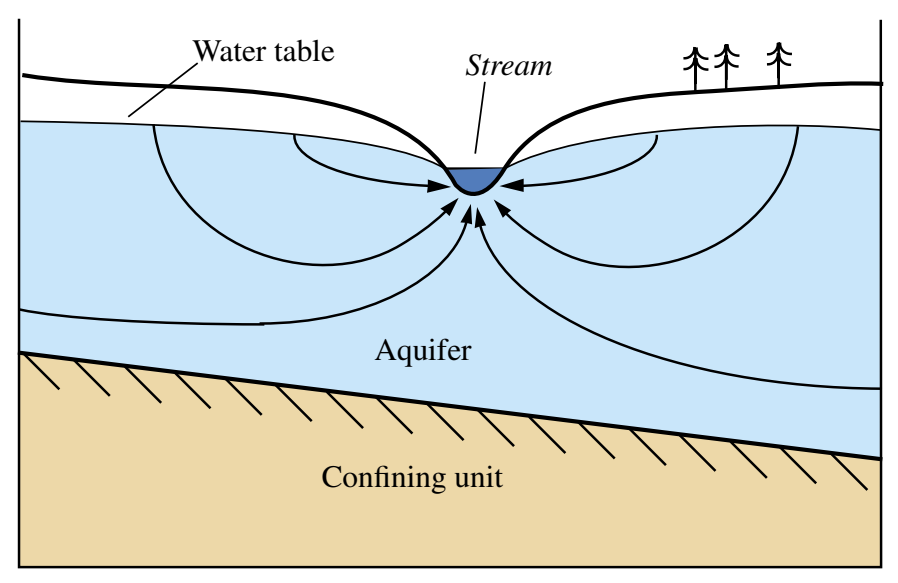

$\mathrm{C}$

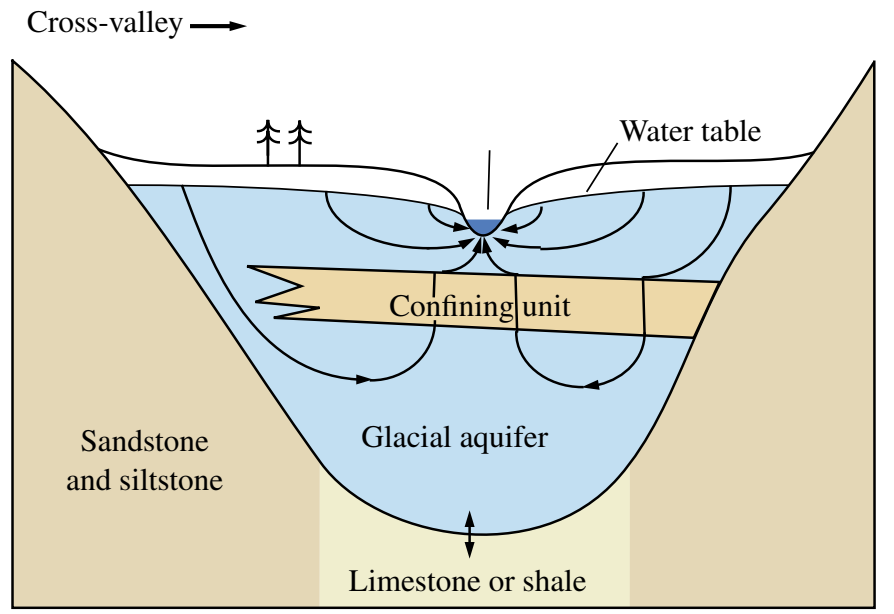

WEST

EAST

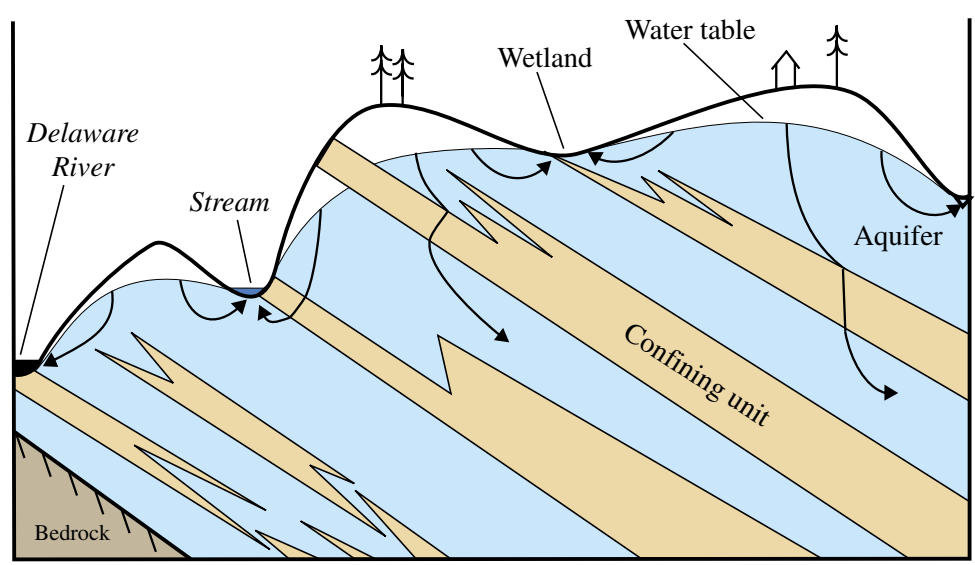

$\mathrm{D}$

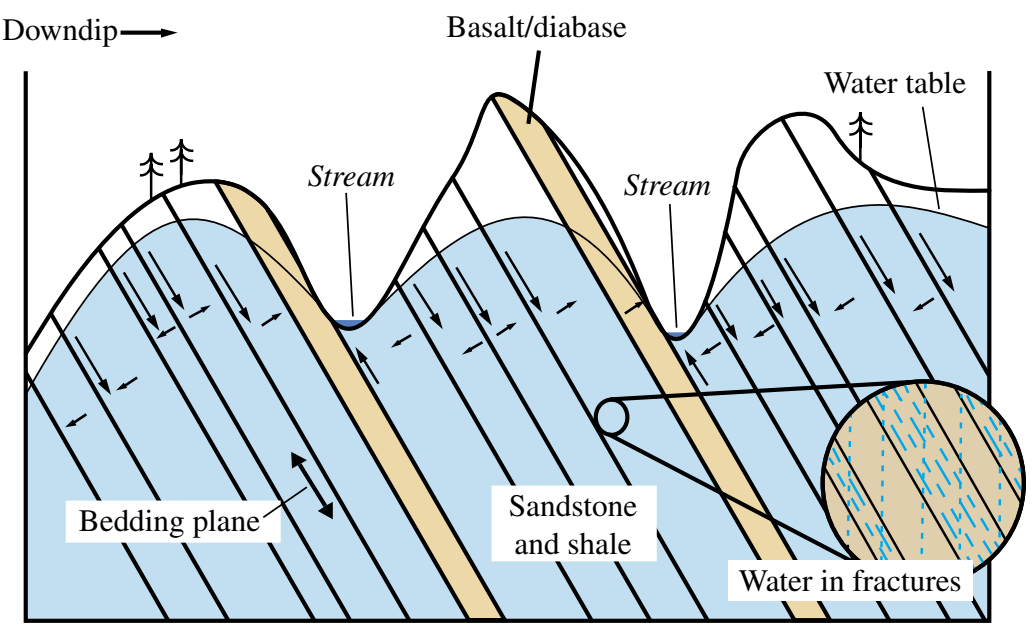

Figure 14. Schematic diagrams of ground-water flow systems in four representative hydrogeologic terrains in New Jersey: (A) unconfined aquifer systems of the Coastal Plain, (B) outcrop areas of confined aquifers in the Coastal Plain, (C) glacial valley-fill aquifers of northern New Jersey, and (D) fractured sedimentary-rock aquifers of the Newark Basin. (From H.T. Buxton, U.S. Geological Survey, written commun., 1998) 
Table 3. Characteristics of aquifers and wells in New Jersey

[Data from U. S. Geological Survey, 1985; ft, feet; mi, miles; gal/min, gallons per minute; Mgal/d, million gallons per day; --, data unavailable]

\begin{tabular}{|c|c|c|c|c|c|}
\hline \multirow[b]{3}{*}{ Aquifer name and description } & \multirow{3}{*}{$\begin{array}{l}\text { Aquifer } \\
\text { withdrawals } \\
\text { in } 1980 \\
\text { (Mgal/d) }\end{array}$} & \multicolumn{3}{|c|}{ Well characteristics } & \multirow[b]{3}{*}{ Remarks } \\
\hline & & \multirow{2}{*}{$\begin{array}{l}\text { Depth } \\
\text { below land } \\
\text { surface } \\
\text { (ft) }\end{array}$} & \multicolumn{2}{|c|}{ Yield (gal/min) } & \\
\hline & & & $\begin{array}{l}\text { Common } \\
\text { range }\end{array}$ & $\begin{array}{c}\text { May } \\
\text { exceed }\end{array}$ & \\
\hline \multicolumn{6}{|c|}{ Coastal Plain aquifers } \\
\hline $\begin{array}{l}\text { Kirkwood-Cohansey aquifer system: } \\
\text { Sand, quartz, fine- to coarse- } \\
\text { grained, pebbly; local clay beds. } \\
\text { Unconfined. }\end{array}$ & 70 & $20-350$ & $500-1,000$ & 1,500 & $\begin{array}{l}\text { Ground water is generally under water-table } \\
\text { conditions. Aquifer system extends from } \\
\text { southern Monmouth County to Delaware Bay } \\
\text { and from } 12 \text { mi southeast of the Delaware } \\
\text { River to the Atlantic Ocean. Aquifer } \\
\text { thickness can exceed } 350 \mathrm{ft} \text {. Brackish and } \\
\text { salty water may occur in coastal areas. }\end{array}$ \\
\hline $\begin{array}{l}\text { Atlantic City } 800 \text {-foot sand: Sand, } \\
\text { quartz, medium- to coarse-grained, } \\
\text { gravel, fragmented shell material. } \\
\text { Confined. }\end{array}$ & 20 & $450-950$ & $600-800$ & 1,000 & $\begin{array}{l}\text { Principal confined artesian aquifer supplying } \\
\text { water along the barrier beaches in Cape May, } \\
\text { Atlantic, and Ocean Counties. Aquifer } \\
\text { thickness generally ranges between } 100 \text { and } \\
150 \mathrm{ft} \text {. Water quality suitable for most uses. }\end{array}$ \\
\hline $\begin{array}{l}\text { Wenonah-Mount Laurel aquifer: Sand, } \\
\text { quartz, slightly glauconitic, very } \\
\text { fine- to coarse-grained, layers of } \\
\text { shells. Confined. }\end{array}$ & 5 & $50-600$ & $50-250$ & 500 & $\begin{array}{l}\text { Important confined aquifer in the northeastern } \\
\text { and southwestern parts of the Coastal Plain. } \\
\text { Aquifer thickness generally ranges between } \\
60 \text { and } 120 \mathrm{ft} \text {. Water quality suitable for most } \\
\text { purposes. }\end{array}$ \\
\hline $\begin{array}{l}\text { Englishtown aquifer system: Sand, } \\
\text { quartz, fine- to medium-grained, } \\
\text { local clay beds. Confined. }\end{array}$ & 12 & $50-1,000$ & $300-500$ & 1,000 & $\begin{array}{l}\text { Important source of water for Ocean and } \\
\text { Monmouth Counties. Confined aquifer } \\
\text { thickness generally ranges between } 60 \text { and } \\
140 \mathrm{ft} \text {. Excellent water quality. }\end{array}$ \\
\hline $\begin{array}{l}\text { Potomac-Raritan-Magothy aquifer } \\
\text { system: Alternating layers of gravel, } \\
\text { sand, silt, and clay. Confined. }\end{array}$ & 243 & $50-1,800$ & $500-1,000$ & 2,000 & $\begin{array}{l}\text { Highly productive and most used confined } \\
\text { aquifers in the Coastal Plain. Aquifer system } \\
\text { extends throughout Coastal Plain and attains } \\
\text { maximum thickness of } 4,100 \mathrm{ft} \text {. Includes two } \\
\text { aquifers in northern Coastal Plain: Farrington } \\
\text { and Old Bridge aquifers. Salty water } \\
\text { increases with depth and in downdip } \\
\text { direction. Excellent water quality but large } \\
\text { iron concentrations in some areas. }\end{array}$ \\
\hline \multicolumn{6}{|c|}{ Non-Coastal Plain aquifers } \\
\hline $\begin{array}{l}\text { Glacial valley-fill aquifers: Sand, } \\
\text { gravel, interbedded silt and clay. } \\
\text { Generally unconfined except where } \\
\text { overlain by lake silt and clay or till. }\end{array}$ & -- & $10-300$ & $100-1,000$ & 2,000 & $\begin{array}{l}\text { North of terminal moraine, these aquifers occur } \\
\text { principally as channel fill in preglacial stream } \\
\text { valleys; south of the moraine, they occur as } \\
\text { outwash plains and valley trains. Important } \\
\text { aquifers in Bergen, Essex, and Morris } \\
\text { Counties. Water quality suitable for most } \\
\text { uses. }\end{array}$ \\
\hline $\begin{array}{l}\text { Aquifers in the Newark Group: Shale, } \\
\text { sandstone, some conglomerate. } \\
\text { Unconfined to partially confined in } \\
\text { upper } 200 \mathrm{ft} \text {; confined at greater } \\
\text { depth. }\end{array}$ & -- & $30-1,500$ & $10-500$ & 1,500 & $\begin{array}{l}\text { Most productive aquifers in Essex, Passaic, and } \\
\text { Union Counties. Water generally hard; may } \\
\text { have large concentrations of iron and sulfate. } \\
\text { Saltwater has intruded into areas of large } \\
\text { ground-water withdrawal near bays and } \\
\text { estuaries. }\end{array}$ \\
\hline $\begin{array}{l}\text { Valley and Ridge sedimentary units: } \\
\text { Predominantly limestone and shale; } \\
\text { some dolomite, calcareous } \\
\text { sandstone and siltstone, sandstone, } \\
\text { conglomerate, and slate. Confined } \\
\text { and unconfined. }\end{array}$ & -- & $150-400$ & $5-500$ & 1,500 & $\begin{array}{l}\text { Highest yields from cavernous limestones and } \\
\text { from weathered and fractured zone within } 300 \\
\mathrm{ft} \text { of land surface. Locally excessive iron } \\
\text { concentrations and hardness, and low pH. }\end{array}$ \\
\hline $\begin{array}{l}\text { New England crystalline units: Gneiss, } \\
\text { marble, quartzite, pegmatite; some } \\
\text { schist, amphibolite, and granite. } \\
\text { Includes thin belts of conglomerate } \\
\text { and sandstone; not significant as } \\
\text { aquifers. Confined and unconfined. }\end{array}$ & -- & $35-800$ & $5-\quad 50$ & 400 & $\begin{array}{l}\text { Most water obtained from weathered and } \\
\text { fractured zone in upper } 300 \mathrm{ft} \text {; high yields in } \\
\text { or near major fault zones. Excellent source of } \\
\text { water for domestic use in some areas. }\end{array}$ \\
\hline
\end{tabular}




\section{Land use can affect the quality, quantity, and distribution of water recharging an aquifer or running overland to streams.}

\section{Land use}

Land use can affect the quality, quantity, and distribution of water recharging an aquifer or running overland to streams (Winters and others, 1998). An increase in impervious surfaces such as parking lots, buildings, and roads decreases the amount of land through which precipitation can recharge the aquifer. Water that cannot infiltrate into the ground increases the amount of overland flow, with the potential for an increase in soil erosion, flooding, and surface-water contamination. Water quality in a watershed typically decreases as development increases. In rural and agricultural areas, septic systems can introduce contaminants to the ground water, feedlots may leach fecal matter into the soil, and pesticides used on farm fields can enter the ground- and surface-water systems. In suburban areas, pesticides or herbicides used on home lawns and rights-of-way can enter the water supply. In cities, industries may discharge waste to streams, and runoff from roads can transport oil and gasoline residue as well as salt used (in the winter) for deicing to streams--all of which degrade water quality. The use of large amounts of water for irrigation and urban and industrial use can reduce the quantity of water available. Water may have to be withdrawn from a nearby stream, pumped from an underlying aquifer, or brought in from a neighboring area to supplement the water supply. Pumping water directly from a stream, however, decreases streamflow, changes the ecological habitat of the stream, and reduces the amount of water available to dilute any contaminants that may be present. Pumping water from an underlying aquifer may decrease ground-water levels and cause water to flow from streams into the aquifer, bringing contaminants along with it. Importing water from neighboring watersheds may raise the water level excessively in some areas, causing flooding. 
All of these examples represent changes in the distribution of water in a watershed. Decreasing streamflow in one location will affect flow at all sites downstream. Lowering the water level in an aquifer in one area will force pumped wells to draw water from farther and farther away, lowering the water level in adjacent areas. Watershed protection programs can help to monitor land-use activities, development, and water use, ultimately protecting the quality and quantity of water in the watershed. Land use in New Jersey in 1991-93 is shown in figure 15. This is a computer plot derived from a geographic information system file. (See Box C.) The northeastern part of the State contains several large urban areas, with smaller centers located around Trenton, Camden, and the Atlantic Shore. Northwestern New Jersey is predominantly forested and southern New Jersey is both agricultural and forested.

\section{Watershed protection programs can help to monitor land-use activities, development, and water use, ultimately protecting the quality and quantity of water in the watershed.}




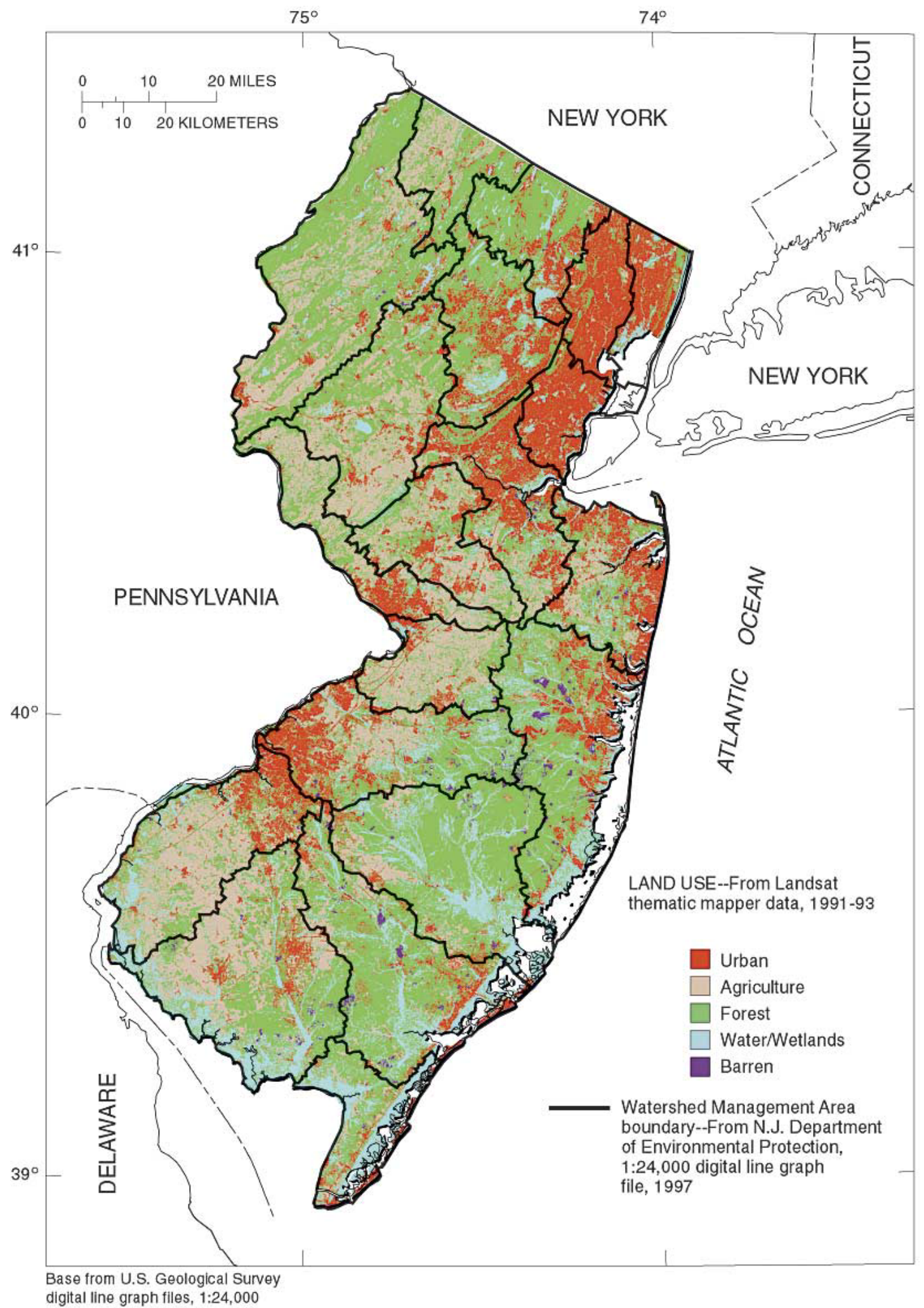

Figure 15. Land use in New Jersey, 1991-93. The large population centers are located in the northeastern part of the State and along the Delaware River. Northwestern New Jersey is predominantly forested. Southern New Jersey is predominantly agricultural and forested. Land-use information is useful for documenting changes over time, for identifying potential risks to ground and surface water, and for water-management planning. 


\section{C}

\section{Cartographic tools used in hydrologic studies}

Aerial photography and remote sensing have long been applied to problems in the earth sciences, such as geologic and topographic mapping (Campbell, 1987). Now cartographic (mapping) tools, such as geographic information systems (GIS), and new imaging techniques such as digital orthophoto quadrangle maps, digital raster graphics, and satellite imaging, are available to help scientists and engineers conduct hydrologic studies. Coupled with land-use maps, these map images allow researchers and planners to accurately document land-use changes in a given area over time. Examples of these types of maps of an area near the Mercer County Airport in central New Jersey are shown here.

Digital raster graphics are scanned images of a USGS topographic map. The lines on the map are "georeferenced" to the surface of the Earth (related to a specific geographic position in the world, such as a specific latitude and longitude). These maps can be used as a base on which to plot additional digital data (U.S. Geological Survey, 1996b).

Digital orthophotos are digital maps of aerial photographs with any displacement caused by the camera or the relief of the terrain removed (U.S. Geological Survey, 1996a). The image has the characteristics of a photograph and the geometric qualities of a map. The accuracy and detail of these images make them easy and invaluable to work with. They can be used to study environmental effects on ground water and surface water, devise emergency evacuation plans, analyze floods, and document soil erosion. Digital orthophotos can be easily rescaled and reformatted, and additional information, such as roads or water-level contours, can be superimposed to meet the user's needs.

The land-use map shown was produced from satellite images that measure the solar radiation reflected from the Earth's surface. Satellite images have advantages over aerial photographs in that large areas can be seen in a single image, distortion is minimized, and multiple images of the same area are available (Campbell, 1987). This land-use map was created by thematic mapper imaging, which is a satellite-based method of data collection. The land-use image, which has a 30-meter by 30-meter resolution, was analyzed and interpreted by using statistical methods to determine the predominant land use (urban, agriculture, forest, or water) in each 30 -meter by 30-meter cell.

Common features can be seen in the three plots of the same area. The airstrip in the upper left is seen as an " $\mathrm{X}$ " on the digital raster graphic and digital orthophoto maps and as urban land on the land-use map. The railroad tracks through the center of the plots are lined by trees (green on the upper half of the land-use map), and the areas of urban and agricultural land can be discerned on each map. 


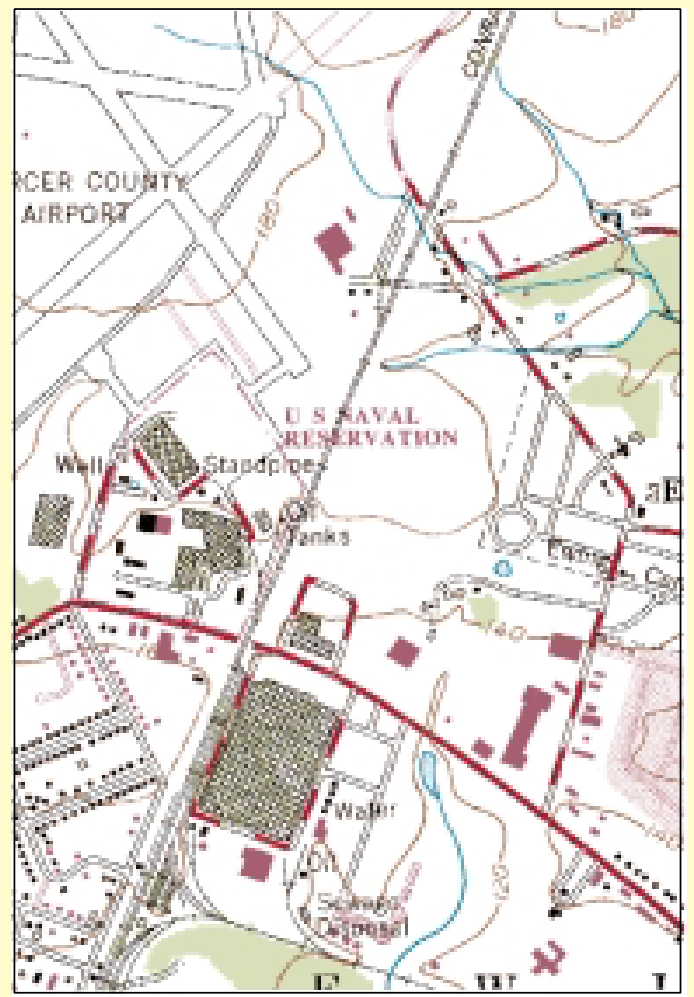

A digital raster graphic is a scanned image of a U.S. Geological Survey topographic map.

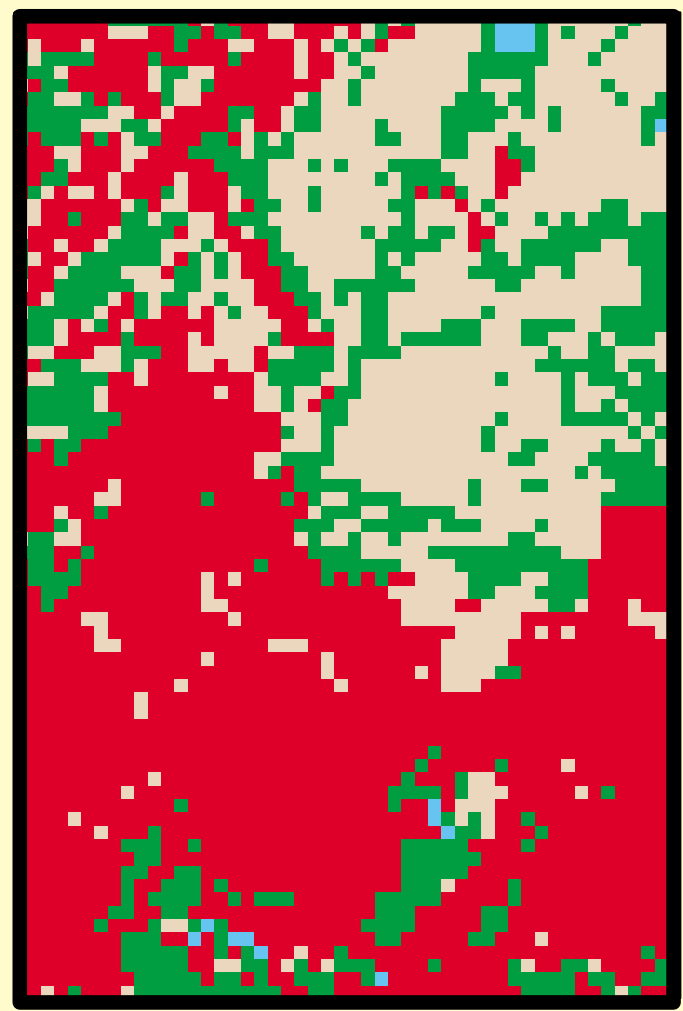

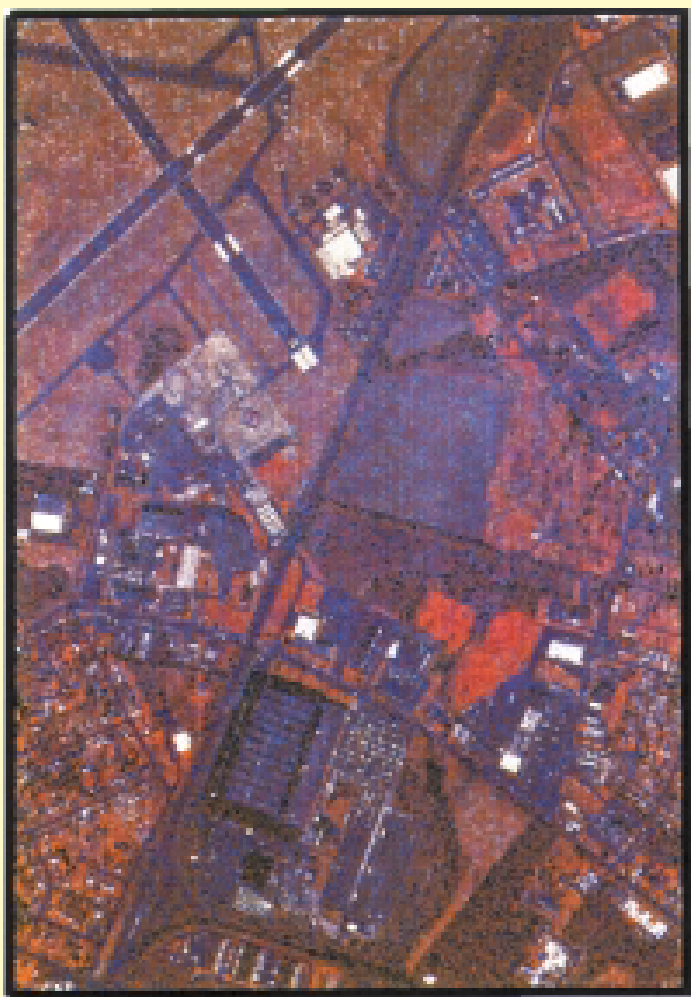

A digital orthophoto is a digital image of an aerial photograph with the distortion removed.

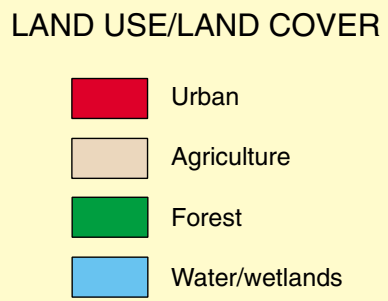

This land-use information is from thematic mapper images (satellite imagery).

Examples of images produced by using advanced imaging techniques together with cartographic tools to study a given area 


\section{Population}

The water resources and population of an area are intricately interconnected. An ample supply of good-quality water provides water for drinking, irrigation, industrial use, and possibly recreation. These factors tend to draw people to an area. As the population grows, land is developed, decreasing the pervious surface area through which infiltration can occur to recharge the aquifers; growing industries and agriculture may discharge contaminants to streams and aquifers; and the drinking-water supply must serve more people.

The growth of New Jersey's population from 1880 to 1990 is shown in figure 16a. Since 1970, New Jersey has had the highest population density in the United States (N.J. Department of Labor, 1991). The population more than quadrupled from 1890 to 1990 , and increased approximately 27 percent from 1960 to 1990 . Along with the population increase has come a need for larger, more efficient publicwater supply systems, additional reservoirs to store water, and more wells in deeper aquifers.

The population of each of the five water regions and population trends for 2010 and 2040, as projected in the New Jersey Statewide Water Supply Plan (N.J. Department of Environmental Protection, 1996c), are shown in figure 16b. The Northeast water region has the smallest land area but the highest population density. This water region is in the most urban and industrialized part of the State (fig. 15). Roughly 35 percent of New Jersey's population lives within this water region. For comparison, the Atlantic Coastal and Lower Delaware water regions, which together have a land area four times that of the Northeast water region, also is home to about 35 percent of the State's population.
The Raritan and Lower Delaware water regions also have large urban centers (fig. 15), but their population densities are smaller than that of the Northeast water region. The Atlantic Coastal and Northwest water regions have the smallest population densities.

The population of the Northeast water region is predicted to decrease slightly by 2040 (fig. 16b) because of a move from urban to suburban areas. The populations of all the other water regions are projected to increase by 2040 .

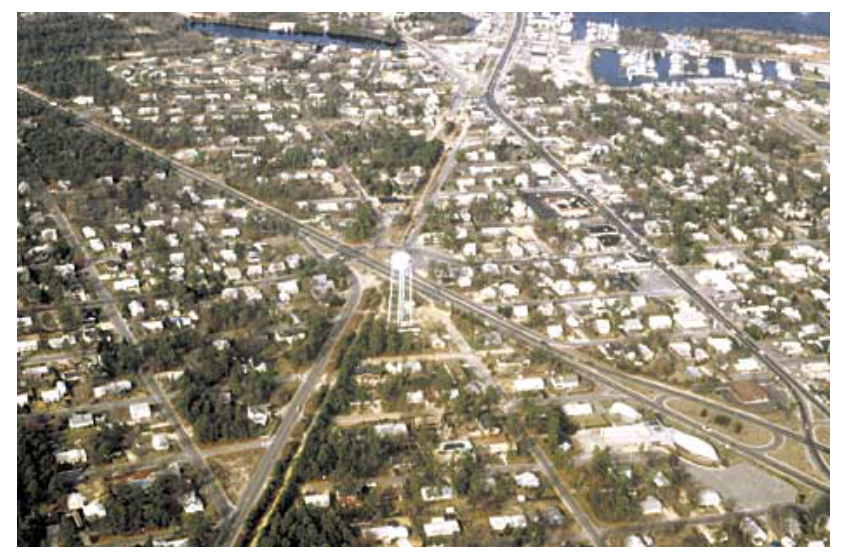

Heavily populated residential area in the northern Coastal Plain, New Jersey. (File photograph, U.S. Geological Survey, West Trenton, New Jersey) 

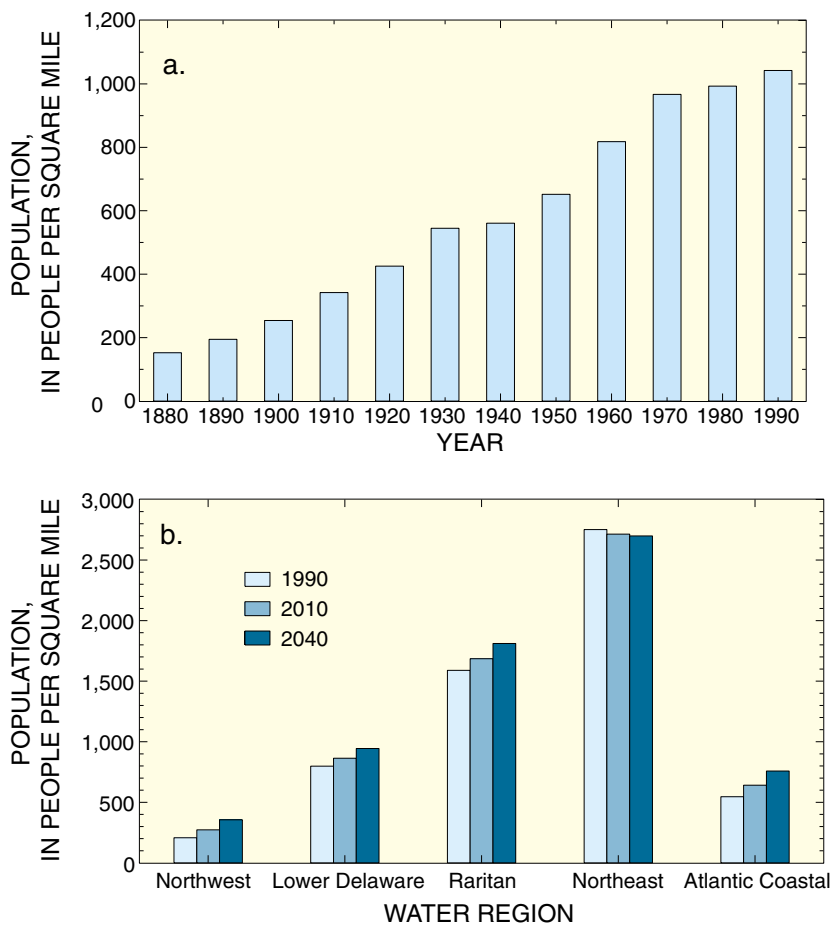

Figure 16. (a) Population density in New Jersey from 1880 to 1990 (data from N.J. Department of Labor, 1991) and (b) population densities of the five water regions in New Jersey in 1990, and projected densities for 2010 and 2040 (N.J. Department of Environmental Protection, 1996c). As of 1990, the population of New Jersey had quadrupled since 1890 and grown 30 percent since 1960. The demands on the water resources are great. Of the five water regions, the Northeast water region has the smallest land area but the greatest population density. Thirty-five percent of the State $s$ population lives in this water region. In contrast, the population of the Atlantic Coastal and Lower Delaware water regions combined make up 35 percent of the State s population. The populations of all water regions except the Northeast are predicted to increase still further by 2010 and 2040 . 


\section{WATER-RESOURCE DATA}

\section{Surface-Water Data}

\section{Streams}

The USGS operates a network of sites throughout the State where streamflow is measured. These data are crucial to regulatory agencies, watershed-management groups, and scientific communities for planning purposes and water-resource studies. Streamflow-gaging stations provide the most complete information, but some streamflow data are collected by other means.

The locations of all the surface-water data-collection sites in New Jersey are shown in figures 17 and 18. Types of data-collection stations are streamflow-gaging stations, discontinued streamflow-gaging stations, crest-stage partial-record stations, lowflow partial-record stations, and tide-gaging stations. At each of these sites, measurements are made at different intervals and for different purposes.

In any given year, about 90 to 100 USGS streamflow-gaging stations are in operation in New Jersey. At these sites, water levels are recorded continuously (every 15 minutes). USGS personnel typically visit these sites once every 6 to 8 weeks to measure discharge (flow rate) to determine the relation between the stage of the stream (the height of the water surface above an established level) and its flow. This information is published by the USGS annually in the water-resources data report (for example, Reed and others, 1998). Real-time data for

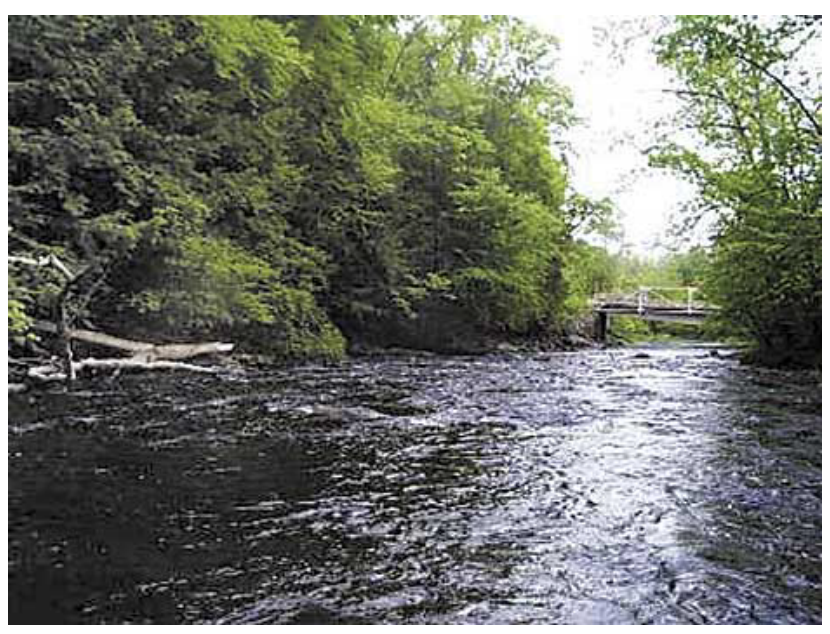

Flatbrook at Flatbrookville, New Jersey, has been gaged since July 1923. (Photograph by Gretchen Wall)

selected sites also are available; these data are posted on the USGS homepage on the Internet (see address in List of Contacts, at end of report). These data are important when up-to-the-minute information on stream stage is needed at frequent intervals for flood forecasting, reservoir operations, and flow prediction. Long-term streamflow data also are important for assessing changes that result from human activities (agricultural practices, urbanization, and ground-water development) or climatic changes (Wahl and others, 1995). The locations of the discontinued streamflow-gaging stations in the State are shown in figure 17. Although measurements are no longer made, the USGS maintains historical streamflow records for these sites. 


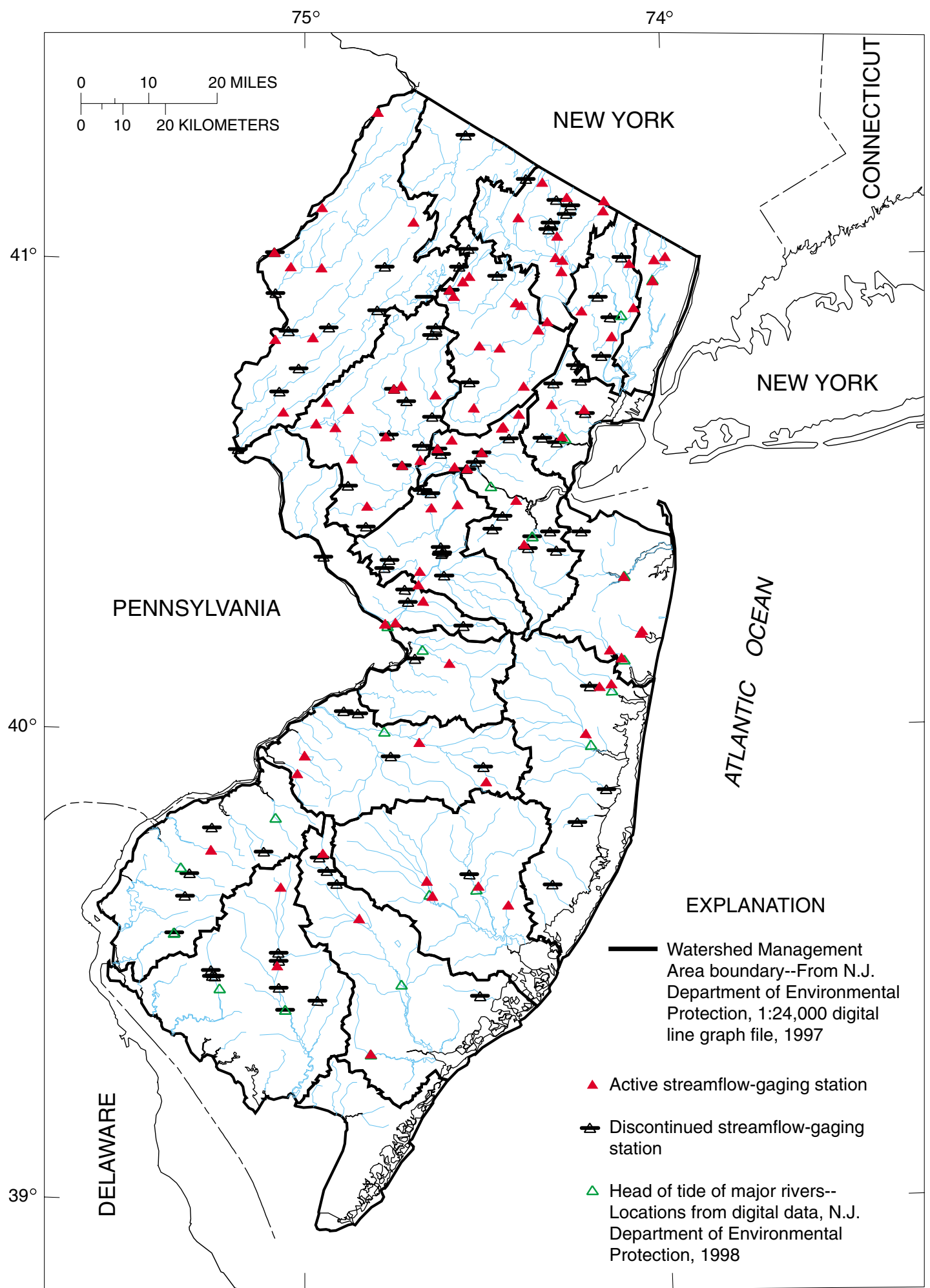

Base from U.S. Geological Survey digital line graph files, 1:24,000

Figure 17. Streamflow-gaging stations active in New Jersey in water year 1997. At these stations, stream stage is measured continuously. This information is used for flood-forecasting, reservoir operation, and predicting flow. At discontinued stations, data are no longer collected, but historical records are maintained by the U.S. Geological Survey. (Head of tide is the point on a stream at which the effects of the tide are no longer observed.) 
Crest-stage gages are established to measure only the highest water level that occurred between visits by USGS personnel. The "bracketing" visit dates, rather than a specific time, are associated with this measurement. These gages are simple, economical, reliable, and easy to install. The highest water level is important to engineers who design highways, culverts, and bridges, and to agencies responsible for the safety and well-being of people in the event of a flood. Between 50 and 100 crest-stage gages are located throughout the State (fig. 18).

Low-flow partial-record sites perform the opposite function of the crest-stage-gage sites. They are located on many streams throughout the State (fig. 18). These sites are established to measure flow during conditions that are presumed to represent base-flow conditions, defined as 3 days with no rain for the northern part of the State and 5 days with no rain for the southern part of the State. (The criterion differs between the northern and the southern parts of the State because of the difference in the storage capacity of the sediments.) No recording devices are installed at these stations; USGS personnel typically visit them twice each year to make discharge measurements. Data collected at low-flow partial-record stations provide an estimate of the base flow, or sustained or fair-weather flow, of the stream. This information is important for setting minimum passing flows, or limiting the discharge from a wastewatertreatment plant to a stream in order to protect the habitat of the fish, plants, and other wildlife.

The USGS has established several different networks to measure the tides in New Jersey's coastal areas (fig. 18). At tide-gaging stations, the height of tides is measured on a continuous basis. The maximum high tide, minimum low tide, and associated dates, as well as mean high and low tides, are published by the USGS annually in the waterdata reports. Tidal crest-stage gages are set up and operate like stream crest-stage gages but are located in stream reaches that are affected by the tides. The largest network that measures the tides is the New Jersey Tide Telemetry System operated by the USGS, which consists of tide gages, tidal-crest-stage gages, weather sensors, and computer base stations. The network stretches from Newark to Cape May and includes the Delaware Bay and Delaware River. It was established to help minimize the extensive damage that can result from flooding in New Jersey's coastal regions and back bays. Also, as the populations of the coastal regions increase, large storms threaten developed areas and timely evacuation of residents is crucial. The telemetry system (electronic equipment that transmits measurements to a base station) that is connected to these gages transmits measurements of tide levels, air and water temperature, rainfall, wind speed and direction, and barometric pressure directly to the National Weather Service, New Jersey State Police, New Jersey Department of Transportation, and county emergency management agencies (the base stations). This information is crucial for flood forecasting, determining evacuation routes, and designing roads and bridges (see Summer, 1998a) (fig. 19).
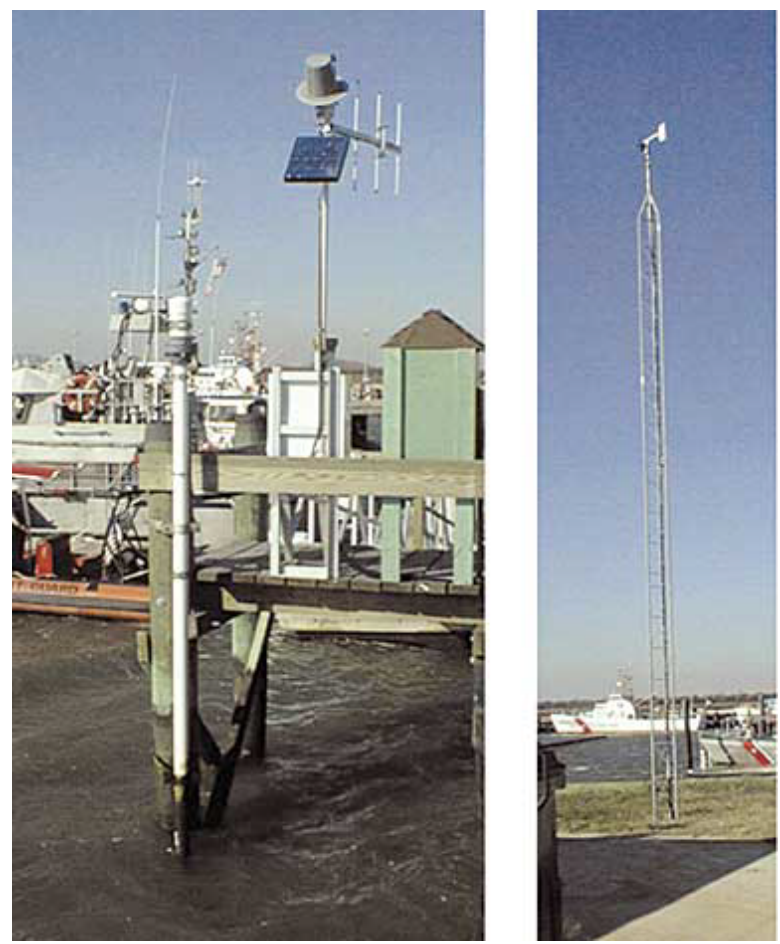

Tide-telemetry (left) and weather-monitoring equipment at Cape May Harbor at U.S. Coast Guard Training Center, Cape May, New Jersey. (Photograph by John Stepnowski, National Ocean Service) 


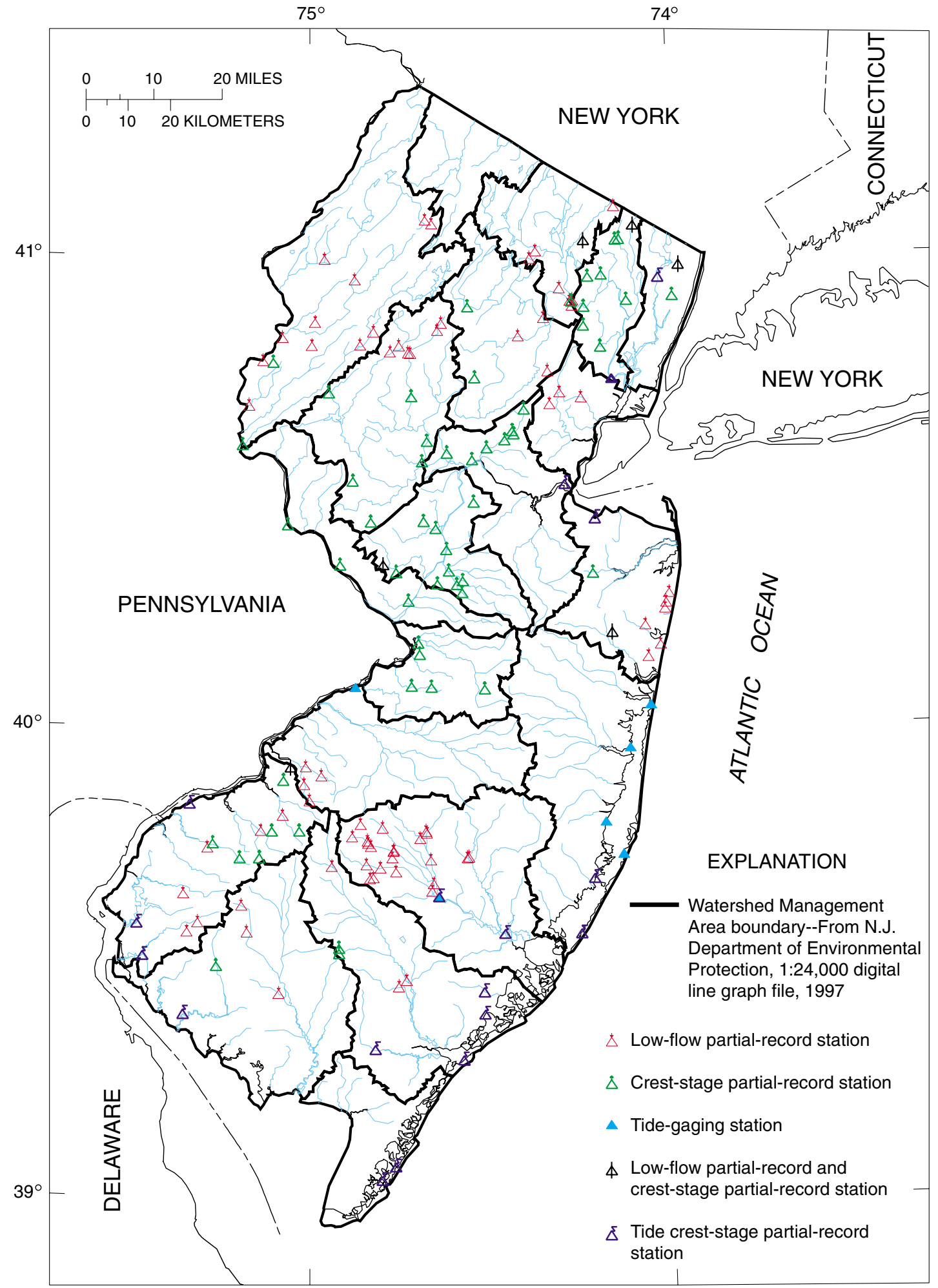

Base from U.S. Geological Survey

digital line graph files, 1:24,000

Figure 18. Low-flow partial-record stations, crest-stage partial-record stations, and tide-gaging stations active in New Jersey in water year 1997. Streamflow is measured at low-flow partialrecord stations under base-flow conditions. Crest-stage partial-record stations record the highest flow during a specific period. Tide gages measure the highs and lows of the tide. 


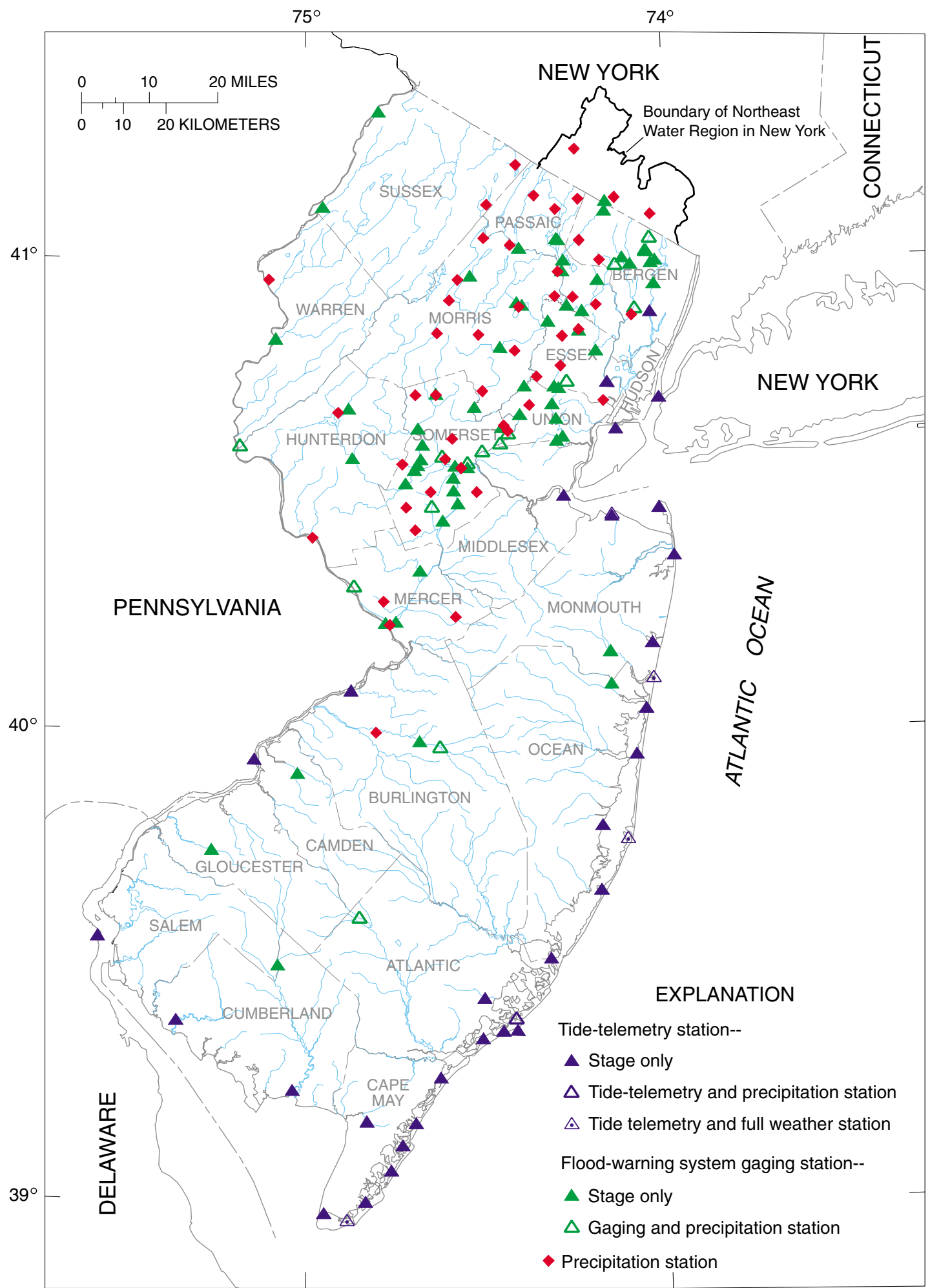

Base from U.S. Geological Survey

digital line graph files, 1:24,000

Figure 19. Tide-telemetry stations, flood-warning systems, and weather stations active in New Jersey in 1999. Information from the tide-telemetry network is used to help protect coastal areas from flooding. The flood-warning systems are located in the most densely populated part of the State to help protect life and property. The information collected by these networks is used for flood-forecasting, determining evacuation routes, and designing roads and bridges. 
Selected data collected at the continuous streamflow-gaging stations in operation in water year ${ }^{1} 1997$ in the State are listed in table 4. Information such as drainage area (size of watershed), period of record (how long the gage has been operating), and the highest annual mean, the lowest annual mean, and the mean annual discharge through 1997 at the gage are shown. Mean annual discharge in cubic feet per second per square mile and mean annual discharge in inches over the drainage basin also are included. These values allow planners and researchers to compare the hydrologic characteristics of watersheds regardless of differences in their size. Mean annual discharge in cubic feet per second per square mile is the average number of cubic feet of water flowing per second from each square mile of area drained, if runoff is assumed to be distributed uniformly in time and area (Reed and others, 1998). Mean annual discharge in inches over the drainage basin--the depth to which the drainage area would be covered if all the discharge for a given period of time were uniformly distributed over it--is a useful statistic because it can be compared to precipitation. The long-term statewide mean annual precipitation is 44.67 inches (1897-1997) (National Oceanic and Atmospheric Administration, 1997). The discharge in inches over the drainage basin can be thought of as the amount of precipitation that is left after evapotranspiration, recharge to deeper aquifers, and ground-water and surface-water withdrawals.

When mean annual discharge at a gaging station, expressed in cubic feet per second per square mile, and mean annual discharge, expressed in inches over the drainage basin, are unusually or unexpectedly high or low in comparison to the same statistic for nearby drainage basins, it is likely that either natural hydrologic conditions or man-made conditions has affected the discharge at the station, or that the period of record at the station is very short. For example, discharge at the Mullica River near Batsto, N.J., streamflow-gaging station is higher than expected because this drainage basin receives inflow from Sleeper Branch, a tributary drainage basin. In contrast, the Oswego River at Harrisville, N.J., loses water to a neighboring drainage basin and, therefore, has a lower than expected discharge. Manmade conditions such as streamflow diversions for municipal supply or filling reservoirs, releases from reservoirs to maintain minimum passing flow, and ground-water withdrawals adjacent to streams all result in lower than normal discharge. Controlled releases from upstream reservoirs reduce discharge at the Wanaque River at Wanaque, N.J., and Hackensack River at New Milford, N.J., streamflow-gaging stations. Other stations, such as South Branch Rockaway River at Whitehouse Station, N.J., may measure the release of water from a reservoir into the stream above the station and thus have higher than normal discharge. Flow statistics for stations with less than 20 years of record may not accurately represent long-term flow characteristics. Flow statistics for the streamflow-gaging station on the Whippany River near Morristown, N.J., is higher than expected, a consequence of the short period of record at the station. This stream has been gaged only since August 1995 and because 1996 was a wetter than normal year, mean annual discharge computed for this station is considered to be higher than normal.

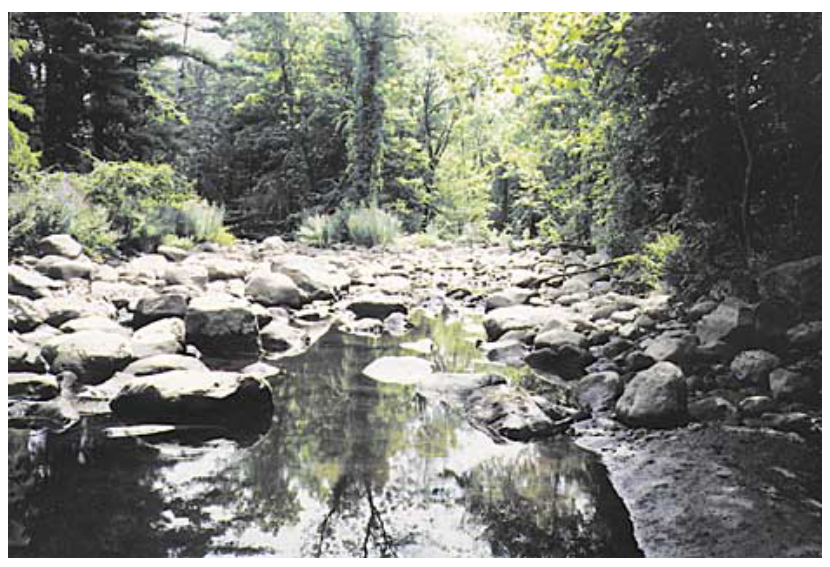

Low water at Pequannock River at Macopin intake dam, New Jersey. (File photograph, U.S. Geological Survey, West Trenton, New Jersey)

\footnotetext{
${ }^{1} \mathrm{~A}$ water year is the 12-month period beginning on October 1 and ending on September 30 . The water year is designated by the calendar year in which it ends.
} 
Table 4. Selected information for continuous streamflow-gaging stations in New Jersey ${ }^{1}$ through water year 1997

\begin{tabular}{|c|c|c|c|c|c|c|c|c|c|c|c|}
\hline \multirow[b]{2}{*}{$\begin{array}{l}\text { U.S. Geological Survey } \\
\text { streamflow-gaging station } \\
\text { name and number }\end{array}$} & \multirow[b]{2}{*}{ County } & \multirow[b]{2}{*}{$\begin{array}{l}\text { Drain- } \\
\text { age area } \\
\text { (square } \\
\text { miles) }\end{array}$} & \multirow[b]{2}{*}{$\begin{array}{l}\text { Period of } \\
\text { record analyzed }\end{array}$} & \multicolumn{7}{|c|}{ Discharge, for period of record analyzed } & \multirow[b]{2}{*}{ Remarks } \\
\hline & & & & $\begin{array}{l}\text { Mean } \\
\text { annual } \\
\text { (cubic feet } \\
\text { per second) }\end{array}$ & $\begin{array}{l}\text { Highest } \\
\text { mean }(\mathrm{cu} \\
\text { per secor } \\
\text { in paren }\end{array}$ & $\begin{array}{l}\text { annual } \\
\text { bic feet } \\
\text { ad; year } \\
\text { theses) }\end{array}$ & $\begin{array}{l}\text { Lowes } \\
\text { mean }(\mathrm{c} \\
\text { per secc } \\
\text { in pare }\end{array}$ & $\begin{array}{l}\text { annual } \\
\text { bic feet } \\
\text { d; year } \\
\text { heses) }\end{array}$ & $\begin{array}{c}\text { Mean } \\
\text { annual } \\
\text { (cubic feet } \\
\text { per second } \\
\text { per square } \\
\text { mile) }\end{array}$ & $\begin{array}{c}\text { Mean } \\
\text { annual } \\
\text { (inches per } \\
\text { year over } \\
\text { drainage } \\
\text { area) }\end{array}$ & \\
\hline \multicolumn{12}{|c|}{ WATER MANAGEMENT AREA 1 - UPPER DELAWARE RIVER } \\
\hline $\begin{array}{l}\text { Delaware River at Montague, } \\
\text { N.J. } 01438500\end{array}$ & $\begin{array}{l}\text { Pike } \\
\text { County, Pa. }\end{array}$ & 3,480 & $\begin{array}{l}\text { Mar. 1936-Sept. } \\
\text { 1939, Oct. 1939- } \\
\text { Sept. } 1997\end{array}$ & 5,717 & 8,621 & $(1952)$ & 2,309 & $(1965)$ & 1.64 & 22.31 & $\begin{array}{l}\text { Discharge regulated by many reservoirs } \\
\text { upstream. Water diverted for New York City } \\
\text { water supply. }\end{array}$ \\
\hline $\begin{array}{l}\text { Flat Brook near Flatbrookville, } \\
\text { N.J. } 01440000\end{array}$ & Sussex & 64.0 & $\begin{array}{l}\text { July 1923-Sept. } \\
1997\end{array}$ & 111 & 210 & (1928) & 43.4 & $(1965)$ & 1.74 & 23.58 & $\begin{array}{l}\text { Discharge occasionally regulated by ponds } \\
\text { upstream. }\end{array}$ \\
\hline $\begin{array}{l}\text { East Branch Paulins Kill near } \\
\text { Lafayette, N.J. } 01443280\end{array}$ & Sussex & 13.0 & $\begin{array}{l}\text { Aug. 1992-Sept. } \\
1997\end{array}$ & 23.4 & 27.2 & $(1996)$ & 15.6 & (1995) & 1.80 & 24.48 & $\begin{array}{l}\text { Possible regulation by pond and golf course } \\
\text { upstream. Significant percentage of base } \\
\text { flow is the result of pumping from limestone } \\
\text { quarry into stream. }\end{array}$ \\
\hline $\begin{array}{l}\text { Paulins Kill at Blairstown, N.J. } \\
01443500\end{array}$ & Warren & 126 & $\begin{array}{l}\text { Oct. 1921-Sept. } \\
\text { 1976, Oct. 1977- } \\
\text { Sept. } 1997\end{array}$ & 198 & 362 & $(1952)$ & 67.4 & (1965) & 1.57 & 21.39 & $\begin{array}{l}\text { Discharge regulated slightly by Swartswood } \\
\text { Lake. }\end{array}$ \\
\hline $\begin{array}{l}\text { Yards Creek near Blairstown, } \\
\text { N.J. } 01443900\end{array}$ & Warren & 5.34 & $\begin{array}{l}\text { Oct. 1966-Sept. } \\
1997\end{array}$ & 11.0 & 16.1 & (1996) & 3.17 & $(1985)$ & 2.06 & 27.97 & $\begin{array}{l}\text { Discharge regulated by Yards Creek Reser- } \\
\text { voir. }\end{array}$ \\
\hline $\begin{array}{l}\text { Pequest River at Pequest, N.J. } \\
01445500\end{array}$ & Warren & 106 & $\begin{array}{l}\text { Oct. 1921-Sept. } \\
1997\end{array}$ & 158 & 285 & $(1952)$ & 45.8 & $(1965)$ & 1.49 & 20.25 & $\begin{array}{l}\text { Discharge affected by some regulation from } \\
\text { unknown sources upstream. }\end{array}$ \\
\hline $\begin{array}{l}\text { Delaware River at Belvidere, } \\
\text { N.J. } 01446500\end{array}$ & Warren & 4,535 & $\begin{array}{l}\text { Oct. 1922-Sept. } \\
1997\end{array}$ & 7,854 & 14,130 & (1928) & 2,990 & $(1965)$ & 1.73 & 23.52 & $\begin{array}{l}\text { Discharge regulated by many lakes and reser- } \\
\text { voirs upstream. Water diverted for New York } \\
\text { City water supply. }\end{array}$ \\
\hline $\begin{array}{l}\text { Musconetcong River near } \\
\text { Bloomsbury, N.J. } 01457000\end{array}$ & Warren & 141 & $\begin{array}{l}\text { July 1903-Mar. } \\
\text { 1907, July 1921- } \\
\text { Sept. } 1997\end{array}$ & 240 & 425 & $(1928)$ & 82.6 & $(1965)$ & 1.70 & 23.11 & Discharge regulated by Lake Hopatcong. \\
\hline \multicolumn{12}{|c|}{ WATER MANAGEMENT AREA 3 - POMPTON, PEQUANNOCK, WANAQUE, AND RAMAPO RIVERS } \\
\hline $\begin{array}{l}\text { Pequannock River at Riverdale, } \\
\text { N.J. } 01382800\end{array}$ & Passaic & 83.9 & $\begin{array}{l}\text { Oct. 1993-Sept. } \\
1997\end{array}$ & 116 & 150 & (1996) & 50.2 & (1995) & 1.38 & 18.77 & $\begin{array}{l}\text { Discharge regulated by Echo Lake, and Can- } \\
\text { istear, Oak Ridge, Clinton, and Charlotteburg } \\
\text { Reservoirs. Water diverted for City of New- } \\
\text { ark water supply. }\end{array}$ \\
\hline $\begin{array}{l}\text { Wanaque River at Awosting, } \\
\text { N.J. } 01383500\end{array}$ & Passaic & 27.1 & $\begin{array}{l}\text { May 1919-Sept. } \\
1997\end{array}$ & 54.5 & 105 & (1984) & 19.9 & (1965) & 2.01 & 27.31 & $\begin{array}{l}\text { Discharge completely regulated by Green- } \\
\text { wood Lake. Water diverted by North Jersey } \\
\text { District Water Supply Commission for } \\
\text { municipal supply. }\end{array}$ \\
\hline $\begin{array}{l}\text { Ringwood Creek near } \\
\text { Wanaque, N.J. } 01384500\end{array}$ & Passaic & 19.1 & $\begin{array}{l}\text { Oct. 1934-Sept. } \\
\text { 1978, Oct. 1985- } \\
\text { Sept. } 1997\end{array}$ & 33.4 & 54.4 & (1952) & 13.2 & (1965) & 1.75 & 23.75 & $\begin{array}{l}\text { Discharge slightly regulated by lakes } \\
\text { upstream. }\end{array}$ \\
\hline
\end{tabular}

${ }^{1}$ Although station 01438500, Delaware River at Montague, N.J., is located in Pennsylvania, it is operated by the U.S. Geological Survey in West Trenton, N.J. 
Table 4. Selected information for continuous streamflow-gaging stations in New Jersey ${ }^{1}$ through water year 1997--Continued

\begin{tabular}{|c|c|c|c|c|c|c|c|c|c|c|c|}
\hline \multirow[b]{2}{*}{$\begin{array}{l}\text { U.S. Geological Survey } \\
\text { streamflow-gaging station } \\
\text { name and number }\end{array}$} & \multirow[b]{2}{*}{ County } & \multirow[b]{2}{*}{$\begin{array}{l}\text { Drain- } \\
\text { age area } \\
\text { (square } \\
\text { miles) }\end{array}$} & \multirow[b]{2}{*}{$\begin{array}{l}\text { Period of } \\
\text { record analyzed }\end{array}$} & \multicolumn{7}{|c|}{ Discharge, for period of record analyzed } & \multirow[b]{2}{*}{ Remarks } \\
\hline & & & & $\begin{array}{c}\text { Mean } \\
\text { annual } \\
\text { (cubic feet } \\
\text { per second) }\end{array}$ & \multicolumn{2}{|c|}{$\begin{array}{l}\text { Highest annual } \\
\text { mean (cubic feet } \\
\text { per second; year } \\
\text { in parentheses) }\end{array}$} & \multicolumn{2}{|c|}{$\begin{array}{l}\text { Lowest annual } \\
\text { mean (cubic feet } \\
\text { per second; year } \\
\text { in parentheses) }\end{array}$} & $\begin{array}{l}\text { Mean } \\
\text { annual } \\
\text { (cubic feet } \\
\text { per second } \\
\text { per square } \\
\text { mile) }\end{array}$ & $\begin{array}{l}\text { Mean } \\
\text { annual } \\
\text { (inches per } \\
\text { year over } \\
\text { drainage } \\
\text { area) }\end{array}$ & \\
\hline \multicolumn{12}{|c|}{ WATER MANAGEMENT AREA 3 - POMPTON, PEQUANNOCK, WANAQUE, AND RAMAPO RIVERS--Continued } \\
\hline $\begin{array}{l}\text { Wanaque River at Wanaque, } \\
\text { N.J. } 01387000\end{array}$ & Passaic & 90.4 & $\begin{array}{l}\text { Dec. 1903-Dec. } \\
\text { 1905, Sept. 1912- } \\
\text { April 1915, May } \\
\text { 1919-Sept. } 1997\end{array}$ & 73.7 & 231 & (1920) & 1.93 & (1966) & .82 & 11.07 & $\begin{array}{l}\text { Discharge regulated by Greenwood Lake, } \\
\text { Monksville and Wanaque Reservoirs. Water } \\
\text { diverted by North Jersey District Water Sup- } \\
\text { ply Commission for municipal supply. }\end{array}$ \\
\hline $\begin{array}{l}\text { Ramapo River near Mahwah, } \\
\text { N.J. } 01387500\end{array}$ & Bergen & 120 & $\begin{array}{l}\text { Oct. 1902-Dec. } \\
\text { 1906, Sept. 1922- } \\
\text { Sept. } 1997\end{array}$ & 230 & 461 & (1903) & 99.5 & (1985) & 1.91 & 25.99 & $\begin{array}{l}\text { Discharge affected by ground-water diver- } \\
\text { sions and regulated by lakes and ponds } \\
\text { upstream. }\end{array}$ \\
\hline $\begin{array}{l}\text { Ramapo River at Pompton } \\
\text { Lakes, N.J. } 01388000\end{array}$ & Passaic & 160 & $\begin{array}{l}\text { Oct. 1921-Sept. } \\
1997\end{array}$ & 287 & 512 & (1984) & 73.1 & (1985) & 1.79 & 24.36 & $\begin{array}{l}\text { Slight regulation of discharge by Pompton } \\
\text { Lake. Discharge regulated by Canistear, Oak } \\
\text { Ridge, Clinton, Monksville, Charlotteburg, } \\
\text { and Wanaque Reservoirs and Greenwood and } \\
\text { Echo Lakes. Water diverted by North Jersey } \\
\text { District Water Supply Commission and } \\
\text { United Water New Jersey for municipal sup- } \\
\text { ply. }\end{array}$ \\
\hline $\begin{array}{l}\text { Pompton River at Pompton } \\
\text { Plains, N.J. } 01388500\end{array}$ & Passaic & 355 & $\begin{array}{l}\text { Mar. 1903-Dec. } \\
\text { 1904, May 1940- } \\
\text { Sept. } 1997\end{array}$ & 490 & 906 & (1952) & 117 & (1965) & 1.38 & 18.74 & $\begin{array}{l}\text { Discharge regulated by Canistear, Oak } \\
\text { Ridge, Clinton, Monksville, Charlotteburg, } \\
\text { and Wanaque Reservoirs and Greenwood and } \\
\text { Echo Lakes. Discharge affected by diver- } \\
\text { sions upstream. }\end{array}$ \\
\hline \multicolumn{12}{|c|}{ WATER MANAGEMENT AREA 4 - LOWER PASSAIC AND SADDLE RIVERS } \\
\hline $\begin{array}{l}\text { Passaic River at Little Falls, } \\
\text { N.J. } 01389500\end{array}$ & Passaic & 762 & $\begin{array}{l}\text { Sept. 1897-Sept. } \\
1997\end{array}$ & 1,146 & 2,394 & (1903) & 269 & (1965) & 1.50 & 20.42 & $\begin{array}{l}\text { Discharge affected by diversion for munici- } \\
\text { pal supply and regulated by reservoirs } \\
\text { upstream. }\end{array}$ \\
\hline $\begin{array}{l}\text { Saddle River at Ridgewood, } \\
\text { N.J. } 01390500\end{array}$ & Bergen & 21.6 & $\begin{array}{l}\text { Oct. 1954-Sept. } \\
\text { 1974, Oct. 1977- }\end{array}$ & 34.4 & 58.7 & (1984) & 14.7 & (1995) & 1.59 & 21.61 & $\begin{array}{l}\text { Discharge affected by municipal well with- } \\
\text { drawals. }\end{array}$ \\
\hline $\begin{array}{l}\text { Saddle River at Lodi, N.J. } \\
01391500\end{array}$ & Bergen & 54.6 & $\begin{array}{l}\text { Sept. 1923-Sept. } \\
1997\end{array}$ & 100 & 187 & (1984) & 45.2 & (1981) & 1.83 & 24.87 & $\begin{array}{l}\text { Discharge affected by surface-water diver- } \\
\text { sions and municipal well withdrawals. }\end{array}$ \\
\hline $\begin{array}{l}\text { Third River at Passaic, N.J. } \\
01392210\end{array}$ & Passaic & 11.8 & $\begin{array}{l}\text { May 1977-Sept. } \\
1997\end{array}$ & 21 & 32.7 & (1978) & 12.7 & (1995) & 1.78 & 24.14 & $\begin{array}{l}\text { Discharge affected by some regulation from } \\
\text { ponds upstream. }\end{array}$ \\
\hline
\end{tabular}


Table 4. Selected information for continuous streamflow-gaging stations in New Jersey ${ }^{1}$ through water year 1997--Continued

\begin{tabular}{|c|c|c|c|c|c|c|c|c|c|c|c|}
\hline \multirow[b]{2}{*}{$\begin{array}{l}\text { U.S. Geological Survey } \\
\text { streamflow-gaging station } \\
\text { name and number }\end{array}$} & \multirow[b]{2}{*}{ County } & \multirow[b]{2}{*}{$\begin{array}{l}\text { Drain- } \\
\text { age area } \\
\text { (square } \\
\text { miles) }\end{array}$} & \multirow[b]{2}{*}{$\begin{array}{l}\text { Period of } \\
\text { record analyzed }\end{array}$} & \multicolumn{7}{|c|}{ Discharge, for period of record analyzed } & \multirow[b]{2}{*}{ Remarks } \\
\hline & & & & $\begin{array}{c}\text { Mean } \\
\text { annual } \\
\text { (cubic feet } \\
\text { per second) }\end{array}$ & \multicolumn{2}{|c|}{$\begin{array}{l}\text { Highest annual } \\
\text { mean (cubic feet } \\
\text { per second; year } \\
\text { in parentheses) }\end{array}$} & \multicolumn{2}{|c|}{$\begin{array}{l}\text { Lowest annual } \\
\text { mean (cubic feet } \\
\text { per second; year } \\
\text { in parentheses) }\end{array}$} & $\begin{array}{c}\begin{array}{c}\text { Mean } \\
\text { annual }\end{array} \\
\text { (cubic feet } \\
\text { per second } \\
\text { per square } \\
\quad \text { mile) }\end{array}$ & $\begin{array}{c}\text { Mean } \\
\text { annual } \\
\text { (inches per } \\
\text { year over } \\
\text { drainage } \\
\text { area) }\end{array}$ & \\
\hline \multicolumn{12}{|c|}{ WATER MANAGEMENT AREA 5 - HACKENSACK RIVER AND PASCACK BROOK } \\
\hline $\begin{array}{l}\text { Hackensack River at River- } \\
\text { vale, N.J. } 01377000\end{array}$ & Bergen & 58 & $\begin{array}{l}\text { Oct. 1941-Sept. } \\
1997\end{array}$ & 88.2 & 156 & $(1952)$ & 30.9 & $(1981)$ & 1.52 & 20.65 & $\begin{array}{l}\text { Discharge affected by diversions and regu- } \\
\text { lated by DeForest Lake and Lake Tappan. }\end{array}$ \\
\hline $\begin{array}{l}\text { Pascack Brook at Westwood, } \\
\text { N.J. } 01377500\end{array}$ & Bergen & 29.6 & $\begin{array}{l}\text { Oct. 1934-Sept. } \\
1997\end{array}$ & 54.3 & 88.6 & $(1952)$ & 27.6 & $(1965)$ & 1.83 & 24.91 & $\begin{array}{l}\text { Discharge regulated by Woodcliff Lake. } \\
\text { Municipal withdrawals in headwaters proba- } \\
\text { bly reduces discharge. }\end{array}$ \\
\hline $\begin{array}{l}\text { Hackensack River at New } \\
\text { Milford, N.J. } 01378500\end{array}$ & Bergen & 113 & $\begin{array}{l}\text { Oct. 1921-Sept. } \\
1997\end{array}$ & 94.1 & 263 & $(1928)$ & .40 & $(1981)$ & .83 & 11.31 & $\begin{array}{l}\text { Discharge affected by diversions and regu- } \\
\text { lated by DeForest Lake, Lake Tappan, Wood- } \\
\text { cliff Lake, and Oradell Reservoir. }\end{array}$ \\
\hline \multicolumn{12}{|c|}{ WATER MANAGEMENT AREA 6 - UPPER PASSAIC, WHIPPANY, AND ROCKAWAY RIVERS } \\
\hline $\begin{array}{l}\text { Passaic River near Millington, } \\
\text { N.J. } 01379000\end{array}$ & Somerset & 55.4 & $\begin{array}{l}\text { Nov. 1903-June } \\
\text { 1906, Oct. 1921- } \\
\text { Sept. } 1997\end{array}$ & 91.7 & 163 & $(1984)$ & 32.3 & $(1965)$ & 1.65 & 22.48 & \\
\hline $\begin{array}{l}\text { Passaic River near Chatham, } \\
\text { N.J. } 01379500\end{array}$ & Morris & 100 & $\begin{array}{l}\text { Feb. 1903-Dec. } \\
\text { 1911, Oct. 1937- } \\
\text { Sept. } 1997\end{array}$ & 173 & 305 & $(1984)$ & 67.7 & $(1965)$ & 1.75 & 23.52 & \\
\hline $\begin{array}{l}\text { Green Pond Brook at Picatinny } \\
\text { Arsenal, N.J. } 01379773\end{array}$ & Morris & 7.65 & $\begin{array}{l}\text { Oct. 1982-Sept. } \\
1997\end{array}$ & 14.0 & 21.4 & $(1984)$ & 6.63 & $(1985)$ & 1.82 & 24.79 & $\begin{array}{l}\text { Discharge affected by some regulation from } \\
\text { Denmark Lake and Green Pond. }\end{array}$ \\
\hline $\begin{array}{l}\text { Green Pond Brook below Pica- } \\
\text { tinny Lake, at Picatinny Arse- } \\
\text { nal, N.J. } 01379780\end{array}$ & Morris & 9.16 & $\begin{array}{l}\text { Oct. 1984-Sept. } \\
1997\end{array}$ & 15.2 & 22.1 & $(1990)$ & 6.35 & $(1985)$ & 1.66 & 22.50 & $\begin{array}{l}\text { Discharge affected by diversions from Pica- } \\
\text { tinny Lake. }\end{array}$ \\
\hline $\begin{array}{l}\text { Green Pond Brook at Wharton, } \\
\text { N.J. } 01379790\end{array}$ & Morris & 12.6 & $\begin{array}{l}\text { Oct. 1982-Sept. } \\
1997\end{array}$ & 25.4 & 40.7 & $(1984)$ & 12.5 & $(1985)$ & 2.01 & 27.35 & $\begin{array}{l}\text { Discharge affected by some regulation from } \\
\text { Picatinny Lake, Picatinny Arsenal sewage- } \\
\text { treatment plant, and flood gates upstream. }\end{array}$ \\
\hline $\begin{array}{l}\text { Rockaway River above Reser- } \\
\text { voir, at Boonton, N.J. } 01380500\end{array}$ & Morris & 116 & $\begin{array}{l}\text { Oct. 1937-Sept. } \\
1997\end{array}$ & 231 & 396 & $(1952)$ & 88.3 & $(1965)$ & 1.99 & 27.04 & Discharge regulated by Splitrock Reservoir. \\
\hline $\begin{array}{l}\text { Rockaway River below Reser- } \\
\text { voir, at Boonton, N.J. } 01381000\end{array}$ & Morris & 119 & $\begin{array}{l}\text { Mar.-Dec. 1903, } \\
\text { Jan., Feb. 1904, } \\
\text { Jan. 1906-Sept. } \\
\text { 1950, Oct. 1950- } \\
\text { Sept. } 1997\end{array}$ & 141 & 296 & $(1952)$ & 7.19 & $(1965)$ & 1.18 & 16.09 & $\begin{array}{l}\text { Discharge regulated by Boonton and } \\
\text { Splitrock Reservoirs. Water diverted for Jer- } \\
\text { sey City municipal water supply. }\end{array}$ \\
\hline $\begin{array}{l}\text { Whippany River near Morris- } \\
\text { town, N.J. } 01381400\end{array}$ & Morris & 14.0 & $\begin{array}{l}\text { Aug. 1995-Sept. } \\
1997\end{array}$ & 43.8 & 50.9 & (1997) & 36.9 & (1996) & 3.13 & 42.56 & $\begin{array}{l}\text { Water diverted at Clyde Potts Reservoir for } \\
\text { municipal water supply. }\end{array}$ \\
\hline
\end{tabular}


Table 4. Selected information for continuous streamflow-gaging stations in New Jersey ${ }^{1}$ through water year 1997--Continued

\begin{tabular}{|c|c|c|c|c|c|c|c|c|c|c|c|}
\hline \multirow[b]{2}{*}{$\begin{array}{c}\text { U.S. Geological Survey } \\
\text { streamflow-gaging station } \\
\text { name and number }\end{array}$} & \multirow[b]{2}{*}{ County } & \multirow[b]{2}{*}{$\begin{array}{l}\text { Drain- } \\
\text { age area } \\
\text { (square } \\
\text { miles) }\end{array}$} & \multirow[b]{2}{*}{$\begin{array}{l}\text { Period of } \\
\text { record analyzed }\end{array}$} & \multicolumn{7}{|c|}{ Discharge, for period of record analyzed } & \multirow[b]{2}{*}{ Remarks } \\
\hline & & & & $\begin{array}{c}\text { Mean } \\
\text { annual } \\
\text { (cubic feet } \\
\text { per second) }\end{array}$ & $\begin{array}{l}\text { Highest } \\
\text { mean }(\mathrm{cu} \\
\text { per secon } \\
\text { in parent }\end{array}$ & $\begin{array}{l}\text { annual } \\
\text { bic feet } \\
\text { id; year } \\
\text { heses) }\end{array}$ & $\begin{array}{l}\text { Lowes } \\
\text { mean }(\mathrm{c} \\
\text { per seco } \\
\text { in pare }\end{array}$ & $\begin{array}{l}\text { annual } \\
\text { bic feet } \\
\text { nd; year } \\
\text { theses) }\end{array}$ & $\begin{array}{c}\text { Mean } \\
\text { annual } \\
\text { (cubic feet } \\
\text { per second } \\
\text { per square } \\
\text { mile) }\end{array}$ & $\begin{array}{c}\text { Mean } \\
\text { annual } \\
\text { (inches per } \\
\text { year over } \\
\text { drainage } \\
\text { area) }\end{array}$ & \\
\hline \multicolumn{12}{|c|}{ WATER MANAGEMENT AREA 6 - UPPER PASSAIC, WHIPPANY, AND ROCKAWAY RIVERS--Continued } \\
\hline $\begin{array}{l}\text { Whippany River at Morristown, } \\
\text { N.J. } 01381500\end{array}$ & Morris & 29.4 & $\begin{array}{l}\text { Aug. 1921-Sept. } \\
1997\end{array}$ & 54.5 & 98.5 & $(1984)$ & 23.3 & $(1965)$ & 1.85 & 25.20 & $\begin{array}{l}\text { Discharge occasionally regulated by opera- } \\
\text { tion of gates at Pocahontas Dam. }\end{array}$ \\
\hline $\begin{array}{l}\text { Passaic River at Pine Brook, } \\
\text { N.J. } 01381900\end{array}$ & Morris & 349 & $\begin{array}{l}\text { Oct. 1979-Sept. } \\
1997\end{array}$ & 640 & 1,125 & (1984) & 276 & $(1981)$ & 1.84 & 24.90 & $\begin{array}{l}\text { Discharge regulated by Boonton and } \\
\text { Splitrock Reservoirs and many small lakes. } \\
\text { Water diverted for Jersey City municipal } \\
\text { water supply. }\end{array}$ \\
\hline $\begin{array}{l}\text { Pequannock River at Macopin } \\
\text { intake dam, N.J. } 01382500\end{array}$ & Morris & 63.7 & $\begin{array}{l}\text { Jan. 1898-Mar. } \\
\text { 1990, Sept. 1992- } \\
\text { Sept. } 1997\end{array}$ & 47.1 & 109 & $(1952)$ & .12 & $(1954)$ & .74 & 10.04 & $\begin{array}{l}\text { Discharge regulated by Canistear, Oak } \\
\text { Ridge, Clinton, and Charlotteburg Reservoirs } \\
\text { and Echo Lake. Water diverted for City of } \\
\text { Newark municipal water supply. }\end{array}$ \\
\hline \multicolumn{12}{|c|}{ WATER MANAGEMENT AREA 7 - ELIZABETH, RAHWAY, AND WOODBRIDGE RIVERS } \\
\hline $\begin{array}{l}\text { Elizabeth River at Ursino Lake, } \\
\text { at Elizabeth, N.J. } 01393450\end{array}$ & Union & 16.9 & $\begin{array}{l}\text { Oct. 1921-Sept. } \\
1997\end{array}$ & 25.9 & 48.3 & $(1971)$ & 10.2 & $(1923)$ & 1.54 & 20.81 & $\begin{array}{l}\text { Discharge affected by municipal well with- } \\
\text { drawals. }\end{array}$ \\
\hline $\begin{array}{l}\text { Rahway River near Springfield, } \\
\text { N.J. } 01394500\end{array}$ & Union & 25.5 & $\begin{array}{l}\text { July 1938-Sept. } \\
1997\end{array}$ & 30.0 & 55.9 & $(1973)$ & 10 & $(1965)$ & 1.18 & 15.98 & $\begin{array}{l}\text { Discharge affected by municipal well with- } \\
\text { drawals. }\end{array}$ \\
\hline $\begin{array}{l}\text { Rahway River at Rahway, N.J. } \\
01395000\end{array}$ & Union & 40.9 & $\begin{array}{l}\text { July 1908-April } \\
\text { 1915, Oct. 1921- } \\
\text { Sept. } 1997\end{array}$ & 48.7 & 105 & $(1973)$ & 15 & $(1965)$ & 1.19 & 16.17 & $\begin{array}{l}\text { Discharge affected by surface-water with- } \\
\text { drawals and municipal well withdrawals. }\end{array}$ \\
\hline \multicolumn{12}{|c|}{ WATER MANAGEMENT AREA 8 - NORTH AND SOUTH BRANCH RARITAN RIVERS } \\
\hline $\begin{array}{l}\text { South Branch Raritan River } \\
\text { near High Bridge, N.J. } \\
01396500\end{array}$ & Hunterdon & 65.3 & $\begin{array}{l}\text { Oct. 1918-Sept. } \\
1997\end{array}$ & 124 & 213 & $(1928)$ & 46.2 & $(1965)$ & 1.89 & 25.71 & $\begin{array}{l}\text { Discharge affected by occasional regulation } \\
\text { from unknown source upstream. }\end{array}$ \\
\hline $\begin{array}{l}\text { Spruce Run at Glen Gardner, } \\
\text { N.J. } 01396580\end{array}$ & Hunterdon & 11.3 & $\begin{array}{l}\text { Mar. 1978-Sept. } \\
\text { 1988, Dec. 1991- } \\
\text { Sept. } 1997\end{array}$ & 21.5 & 33.3 & (1984) & 11.3 & (1995) & 1.90 & 25.84 & $\begin{array}{l}\text { Discharge affected by occasional regulation } \\
\text { from unknown source upstream. }\end{array}$ \\
\hline $\begin{array}{l}\text { Mulhockaway Creek at Van } \\
\text { Syckel, N.J. } 01396660\end{array}$ & Hunterdon & 11.8 & $\begin{array}{l}\text { July 1977-Sept. } \\
1997\end{array}$ & 20.5 & 35.2 & (1984) & 11.1 & (1992) & 1.74 & 23.60 & \\
\hline $\begin{array}{l}\text { Spruce Run at Clinton, N.J. } \\
01396800\end{array}$ & Hunterdon & 41.3 & $\begin{array}{l}\text { May 1959-Sept. } \\
1997\end{array}$ & 66.3 & 111 & (1997) & 3.81 & (1964) & 1.61 & 21.80 & $\begin{array}{l}\text { Discharge regulated by Spruce Run Reser- } \\
\text { voir. }\end{array}$ \\
\hline $\begin{array}{l}\text { South Branch Raritan River at } \\
\text { Stanton, N.J. } 01397000\end{array}$ & Hunterdon & 147 & $\begin{array}{l}\text { July 1903-Dec. } \\
\text { 1906, July 1919- } \\
\text { Sept. } 1997\end{array}$ & 249 & 413 & (1952) & 95.0 & (1966) & 1.69 & 23.00 & $\begin{array}{l}\text { Discharge affected by diversions and regu- } \\
\text { lated by Spruce Run Reservoir. }\end{array}$ \\
\hline
\end{tabular}


Table 4. Selected information for continuous streamflow-gaging stations in New Jersey ${ }^{1}$ through water year 1997--Continued

\begin{tabular}{|c|c|c|c|c|c|c|c|c|c|c|c|}
\hline \multirow[b]{2}{*}{$\begin{array}{l}\text { U.S. Geological Survey } \\
\text { streamflow-gaging station } \\
\text { name and number }\end{array}$} & \multirow[b]{2}{*}{ County } & \multirow[b]{2}{*}{$\begin{array}{l}\text { Drain- } \\
\text { age area } \\
\text { (square } \\
\text { miles) }\end{array}$} & \multirow[b]{2}{*}{$\begin{array}{l}\text { Period of } \\
\text { record analyzed }\end{array}$} & \multicolumn{7}{|c|}{ Discharge, for period of record analyzed } & \multirow[b]{2}{*}{ Remarks } \\
\hline & & & & $\begin{array}{c}\text { Mean } \\
\text { annual } \\
\text { (cubic feet } \\
\text { per second) }\end{array}$ & \multicolumn{2}{|c|}{$\begin{array}{l}\text { Highest annual } \\
\text { mean (cubic feet } \\
\text { per second; year } \\
\text { in parentheses) }\end{array}$} & \multicolumn{2}{|c|}{$\begin{array}{l}\text { Lowest annual } \\
\text { mean (cubic feet } \\
\text { per second; year } \\
\text { in parentheses) }\end{array}$} & $\begin{array}{c}\text { Mean } \\
\text { annual } \\
\text { (cubic feet } \\
\text { per second } \\
\text { per square } \\
\text { mile) }\end{array}$ & $\begin{array}{c}\text { Mean } \\
\text { annual } \\
\text { (inches per } \\
\text { year over } \\
\text { drainage } \\
\text { area) }\end{array}$ & \\
\hline \multicolumn{12}{|c|}{ WATER MANAGEMENT AREA 8 - NORTH AND SOUTH BRANCH RARITAN RIVERS--Continued } \\
\hline $\begin{array}{l}\text { Neshanic River at Reaville, } \\
\text { N.J. } 01398000\end{array}$ & Hunterdon & 25.7 & $\begin{array}{l}\text { June 1930-Sept. } \\
1997\end{array}$ & 37.9 & 70.8 & (1994) & 14.5 & $(1965)$ & 1.47 & 20.04 & \\
\hline $\begin{array}{l}\text { North Branch Raritan River } \\
\text { near Far Hills, N.J. } 01398500\end{array}$ & Somerset & 26.2 & $\begin{array}{l}\text { Oct. 1921-Sept. } \\
\text { 1975, Oct. 1977- } \\
\text { Sept. } 1997\end{array}$ & 48.6 & 89.7 & $(1928)$ & 17.7 & $(1965)$ & 1.85 & 25.19 & \\
\hline $\begin{array}{l}\text { Lamington (Black) River near } \\
\text { Pottersville, N.J. } 01399500\end{array}$ & Morris & 32.8 & $\begin{array}{l}\text { Oct. 1921-Sept. } \\
1997\end{array}$ & 56.3 & 104 & $(1928)$ & 20.5 & $(1965)$ & 1.72 & 23.32 & \\
\hline $\begin{array}{l}\text { Upper Cold Brook near Potters- } \\
\text { ville, N.J. } 01399510\end{array}$ & Hunterdon & 2.18 & $\begin{array}{l}\text { Oct. 1972-Sept. } \\
1996\end{array}$ & 3.91 & 7.07 & $(1984)$ & 1.75 & $(1985)$ & 1.79 & 24.37 & \\
\hline $\begin{array}{l}\text { South Branch Rockaway Creek } \\
\text { at Whitehouse Station, N.J. } \\
01399670\end{array}$ & Hunterdon & 12.3 & $\begin{array}{l}\text { Oct. 1986-Sept. } \\
1997\end{array}$ & 28.1 & 55.2 & $(1981)$ & 11.1 & $(1992)$ & 2.28 & 31.02 & $\begin{array}{l}\text { Discharge affected by releases from Round } \\
\text { Valley Reservoir which enters upstream from } \\
\text { gage. }\end{array}$ \\
\hline $\begin{array}{l}\text { North Branch Raritan River } \\
\text { near Raritan, N.J. } 01400000\end{array}$ & Somerset & 190 & $\begin{array}{l}\text { July 1923-Sept. } \\
1997\end{array}$ & 312 & 605 & $(1984)$ & 120 & (1965) & 1.64 & 22.30 & $\begin{array}{l}\text { Discharge affected by releases from Round } \\
\text { Valley Reservoir which enters upstream from } \\
\text { gage. }\end{array}$ \\
\hline \multicolumn{12}{|c|}{ WATER MANAGEMENT AREA 9 - LOWER RARITAN RIVER, SOUTH RIVER, AND LAWRENCE BROOK } \\
\hline $\begin{array}{l}\text { Raritan River at Manville, N.J. } \\
01400500\end{array}$ & Somerset & 490 & $\begin{array}{l}\text { June 1903-Mar. } \\
\text { 1907, Aug. 1908- } \\
\text { April 1915, Aug. } \\
\text { 1921-Sept. } 1997\end{array}$ & 779 & 1,365 & $(1984)$ & 309 & $(1965)$ & 1.59 & 21.59 & $\begin{array}{l}\text { Discharge affected by diversions and regu- } \\
\text { lated by Round Valley and Spruce Run Res- } \\
\text { rs. }\end{array}$ \\
\hline $\begin{array}{l}\text { Raritan River below Calco } \\
\text { Dam at Bound Brook, N.J. } \\
01403060\end{array}$ & Somerset & 785 & $\begin{array}{l}\text { Sept. 1903-Mar. } \\
\text { 1909, Oct. 1944- } \\
\text { Sept. } 1997\end{array}$ & 1,208 & 2,046 & $(1975)$ & 480 & $(1985)$ & 1.54 & 20.90 & $\begin{array}{l}\text { Discharge affected by diversions for munici- } \\
\text { pal supply and regulated by Spruce Run and } \\
\text { Round Valley Reservoirs. }\end{array}$ \\
\hline $\begin{array}{l}\text { West Branch Middle Brook } \\
\text { near Martinsville, N.J. } \\
01403150\end{array}$ & Somerset & 1.99 & $\begin{array}{l}\text { June 1979-Sept. } \\
1997\end{array}$ & 3.74 & 5.48 & (1989) & 1.88 & (1981) & 1.88 & 25.51 & \\
\hline $\begin{array}{l}\text { Green Brook at Seeley Mills, } \\
\text { N.J. } 01403400\end{array}$ & Somerset & 6.23 & $\begin{array}{l}\text { June 1979-Sept. } \\
1997\end{array}$ & 10.6 & 18.2 & (1984) & 5.16 & (1981) & 1.71 & 23.19 & \\
\hline $\begin{array}{l}\text { East Branch Stony Brook at } \\
\text { Best Lake, at Watchung, N.J. } \\
01403535\end{array}$ & Somerset & 1.57 & $\begin{array}{l}\text { July 1980-Sept. } \\
1997\end{array}$ & 2.71 & 4.47 & (1984) & 1.48 & (1981) & 1.73 & 23.44 & \\
\hline $\begin{array}{l}\text { Stony Brook at Watchung, N.J. } \\
01403540\end{array}$ & Somerset & 5.51 & $\begin{array}{l}\text { Oct. 1974-Sept. } \\
1997\end{array}$ & 10.2 & 16.0 & (1984) & 5.43 & (1995) & 1.85 & 25.17 & \\
\hline
\end{tabular}


Table 4. Selected information for continuous streamflow-gaging stations in New Jersey ${ }^{1}$ through water year $1997--$ Continued

\begin{tabular}{|c|c|c|c|c|c|c|c|c|c|c|c|}
\hline \multirow[b]{2}{*}{$\begin{array}{l}\text { U.S. Geological Survey } \\
\text { streamflow-gaging station } \\
\text { name and number }\end{array}$} & \multirow[b]{2}{*}{ County } & \multirow[b]{2}{*}{$\begin{array}{l}\text { Drain- } \\
\text { age area } \\
\text { (square } \\
\text { miles) }\end{array}$} & \multirow[b]{2}{*}{$\begin{array}{l}\text { Period of } \\
\text { record analyzed }\end{array}$} & \multicolumn{7}{|c|}{ Discharge, for period of record analyzed } & \multirow[b]{2}{*}{ Remarks } \\
\hline & & & & $\begin{array}{l}\text { Mean } \\
\text { annual } \\
\text { (cubic feet } \\
\text { per second) }\end{array}$ & $\begin{array}{l}\text { Highest } \\
\text { mean }(\mathrm{cu} \\
\text { per secon } \\
\text { in parent }\end{array}$ & $\begin{array}{l}\text { annual } \\
\text { bic feet } \\
\text { ad; year } \\
\text { theses) }\end{array}$ & $\begin{array}{l}\text { Lowest } \\
\text { mean }(\mathrm{c} \\
\text { per seco } \\
\text { in pare }\end{array}$ & $\begin{array}{l}\text { innual } \\
\text { bic feet } \\
\text { d; year } \\
\text { heses) }\end{array}$ & $\begin{array}{c}\text { Mean } \\
\text { annual } \\
\text { (cubic feet } \\
\text { per second } \\
\text { per square } \\
\text { mile) }\end{array}$ & $\begin{array}{c}\text { Mean } \\
\text { annual } \\
\text { (inches per } \\
\text { year over } \\
\text { drainage } \\
\text { area) }\end{array}$ & \\
\hline \multicolumn{12}{|c|}{ WATER MANAGEMENT AREA 9 - LOWER RARITAN RIVER, SOUTH RIVER, AND LAWRENCE BROOK--Continued } \\
\hline $\begin{array}{l}\text { Bound Brook at Middlesex, } \\
\text { N.J. } 01403900\end{array}$ & Somerset & 48.4 & $\begin{array}{l}\text { Oct. 1972-Oct. } \\
\text { 1977, April 1996- } \\
\text { Sept. } 1997\end{array}$ & 79.3 & 112 & (1973) & 40.3 & (1977) & 1.63 & 22.25 & \\
\hline $\begin{array}{l}\text { Lawrence Brook at Weston } \\
\text { Mills, N.J. } 01405030\end{array}$ & Middlesex & 44.9 & $\begin{array}{l}\text { Dec. 1988-Oct. } \\
\text { 1994, July 1995- } \\
\text { Sept. } 1997\end{array}$ & 53.6 & 68.7 & $(1993)$ & 30.6 & $(1995)$ & 1.19 & 16.21 & $\begin{array}{l}\text { Discharge regulated by Farrington Lake and } \\
\text { affected by diversions by New Brunswick } \\
\text { Water Department for municipal supply. }\end{array}$ \\
\hline $\begin{array}{l}\text { Manalapan Brook at } \\
\text { Spotswood, N.J. } 01405400\end{array}$ & Middlesex & 40.7 & $\begin{array}{l}\text { Jan. 1957-Sept. } \\
1997\end{array}$ & 63.1 & 101 & $(1973)$ & 34.3 & $(1981)$ & 1.55 & 21.05 & $\begin{array}{l}\text { Discharge affected by some regulation by } \\
\text { Lake Manalapan, Helmetta Pond, and DeVoe } \\
\text { Lake and ground-water withdrawals. }\end{array}$ \\
\hline \multicolumn{12}{|c|}{ WATER MANAGEMENT AREA 10 - MILLSTONE RIVER } \\
\hline $\begin{array}{l}\text { Stony Brook at Princeton, N.J. } \\
01401000\end{array}$ & Mercer & 44.5 & $\begin{array}{l}\text { Oct. 1953-Sept. } \\
1997\end{array}$ & 66.7 & 118 & $(1996)$ & 28.5 & (1966) & 1.50 & 20.36 & $\begin{array}{l}\text { Discharge regulated by several small reser- } \\
\text { voirs. }\end{array}$ \\
\hline $\begin{array}{l}\text { Pike Run at Belle Mead, N.J. } \\
01401650\end{array}$ & Somerset & 5.36 & $\begin{array}{l}\text { July 1980-Sept. } \\
1997\end{array}$ & 9.07 & 14.3 & $(1984)$ & 3.79 & $(1981)$ & 1.69 & 22.99 & \\
\hline $\begin{array}{l}\text { Millstone River at Blackwells } \\
\text { Mills, N.J. } 01402000\end{array}$ & Somerset & 258 & $\begin{array}{l}\text { June 1903-Dec. } \\
\text { 1904, Aug. 1921- } \\
\text { Sept. } 1997\end{array}$ & 383 & 690 & $(1975)$ & 165 & $(1985)$ & 1.48 & 20.17 & $\begin{array}{l}\text { Discharge slightly regulated by Carnegie } \\
\text { Lake and several small reservoirs. Discharge } \\
\text { affected by inflows and losses to the Dela- } \\
\text { ware and Raritan Canal. }\end{array}$ \\
\hline \multicolumn{12}{|c|}{ WATER MANAGEMENT AREA 11 - CENTRAL DELAWARE TRIBUTARIES } \\
\hline $\begin{array}{l}\text { Delaware and Raritan Canal at } \\
\text { Port Mercer, N.J. } 01460440\end{array}$ & Mercer & -- & $\begin{array}{l}\text { Aug. 1990-Sept. } \\
1997\end{array}$ & 134 & 143 & (1991) & 120 & $(1992)$ & -- & -- & $\begin{array}{l}\text { Discharge affected by diversions from the } \\
\text { Delaware River to Raritan River Basin for } \\
\text { municipal supply. }\end{array}$ \\
\hline $\begin{array}{l}\text { Delaware River at Trenton, N.J. } \\
01463500\end{array}$ & Mercer & 6,780 & $\begin{array}{l}\text { Feb. 1913-Sept. } \\
1997\end{array}$ & 11,700 & 19,810 & $(1928)$ & 4,708 & $(1965)$ & 1.72 & 23.43 & $\begin{array}{l}\text { Discharge affected by diversions and regu- } \\
\text { lated by many reservoirs upstream. }\end{array}$ \\
\hline $\begin{array}{l}\text { Assunpink Creek at Trenton, } \\
\text { N.J. } 01464000\end{array}$ & Mercer & 90.6 & $\begin{array}{l}\text { Aug 1923-Sept. } \\
1997\end{array}$ & 133 & 233 & $(1984)$ & 69.2 & $(1931)$ & 1.47 & 19.94 & $\begin{array}{l}\text { Discharge regulated by flood-control reser- } \\
\text { voir upstream. }\end{array}$ \\
\hline \multicolumn{12}{|c|}{ WATER MANAGEMENT AREA 12 - MONMOUTH WATERSHEDS } \\
\hline $\begin{array}{l}\text { Swimming River near Red } \\
\text { Bank, N.J. } 01407500\end{array}$ & Monmouth & 49.2 & $\begin{array}{l}\text { Aug. 1922-Sept. } \\
1997\end{array}$ & $81.0 *$ & 123 & $(1928)$ & 9.76 & $(1985)$ & 1.28 & 17.41 & $\begin{array}{l}\text { Discharge regulated by Swimming River } \\
\text { Reservoir and diversions for municipal sup- } \\
\text { ply. }\end{array}$ \\
\hline $\begin{array}{l}\text { Shark River near Neptune City, } \\
\text { N.J. } 01407705\end{array}$ & Monmouth & 9.96 & $\begin{array}{l}\text { Oct. 1966-Sept. } \\
1997\end{array}$ & 14.3 & 24.9 & (1984) & 6.80 & (1995) & 1.44 & 19.50 & $\begin{array}{l}\text { Discharge affected by diversion above station } \\
\text { for municipal supply and irrigation. }\end{array}$ \\
\hline $\begin{array}{l}\text { Jumping Brook near Neptune } \\
\text { City, N.J. } 01407760\end{array}$ & Monmouth & 6.46 & $\begin{array}{l}\text { Oct. 1966-Sept. } \\
1997\end{array}$ & 9.91 & 20.4 & (1979) & 4.05 & (1981) & 1.53 & 20.83 & $\begin{array}{l}\text { Discharge affected by diversion above station } \\
\text { for municipal supply and irrigation. }\end{array}$ \\
\hline
\end{tabular}


Table 4. Selected information for continuous streamflow-gaging stations in New Jersey ${ }^{1}$ through water year 1997--Continued

\begin{tabular}{|c|c|c|c|c|c|c|c|c|c|c|c|}
\hline \multirow[b]{2}{*}{$\begin{array}{c}\text { U.S. Geological Survey } \\
\text { streamflow-gaging station } \\
\text { name and number }\end{array}$} & \multirow[b]{2}{*}{ County } & \multirow[b]{2}{*}{$\begin{array}{l}\text { Drain- } \\
\text { age area } \\
\text { (square } \\
\text { miles) }\end{array}$} & \multirow[b]{2}{*}{$\begin{array}{l}\text { Period of } \\
\text { record analyzed }\end{array}$} & \multicolumn{7}{|c|}{ Discharge, for period of record analyzed } & \multirow[b]{2}{*}{ Remarks } \\
\hline & & & & $\begin{array}{c}\text { Mean } \\
\text { annual } \\
\text { (cubic feet } \\
\text { per second) }\end{array}$ & \multicolumn{2}{|c|}{$\begin{array}{l}\text { Highest annual } \\
\text { mean (cubic feet } \\
\text { per second; year } \\
\text { in parentheses) }\end{array}$} & \multicolumn{2}{|c|}{$\begin{array}{l}\text { Lowest annual } \\
\text { mean (cubic feet } \\
\text { per second; year } \\
\text { in parentheses) }\end{array}$} & $\begin{array}{l}\text { Mean } \\
\text { annual } \\
\text { (cubic feet } \\
\text { per second } \\
\text { per square } \\
\text { mile) }\end{array}$ & $\begin{array}{l}\text { Mean } \\
\text { annual } \\
\text { (inches per } \\
\text { year over } \\
\text { drainage } \\
\text { area) }\end{array}$ & \\
\hline \multicolumn{12}{|c|}{ WATER MANAGEMENT AREA 12 - MONMOUTH WATERSHEDS--Continued } \\
\hline $\begin{array}{l}\text { Manasquan River at Squankum, } \\
\text { N.J. } 01408000\end{array}$ & Monmouth & 44.0 & $\begin{array}{l}\text { July } 1931- \\
\text { Sept. } 1997\end{array}$ & 74.4 & 131 & $(1978)$ & 40.2 & $(1995)$ & 1.69 & 22.99 & \\
\hline $\begin{array}{l}\text { Manasquan River near Allen- } \\
\text { wood, N.J. } 01408029\end{array}$ & Monmouth & 63.3 & $\begin{array}{l}\text { June } 1990- \\
\text { Sept. } 1997\end{array}$ & 81.2 & 103 & $(1997)$ & 39.4 & $(1995)$ & 1.28 & 17.42 & $\begin{array}{l}\text { Discharge affected by diversions for munici- } \\
\text { pal supply. }\end{array}$ \\
\hline \multicolumn{12}{|c|}{ WATER MANAGEMENT AREA 13 - BARNEGAT BAY WATERSHEDS } \\
\hline $\begin{array}{l}\text { North Branch Metedeconk } \\
\text { River near Lakewood, N.J. } \\
01408120\end{array}$ & Ocean & 34.9 & $\begin{array}{l}\text { Oct. 1972-Sept. } \\
1997\end{array}$ & 60.5 & 91.5 & $(1984)$ & 34.7 & $(1981)$ & 1.73 & 23.54 & \\
\hline $\begin{array}{l}\text { South Branch Metedeconk } \\
\text { River near Lakewood, N.J. } \\
01408150\end{array}$ & Ocean & 27.5 & $\begin{array}{l}\text { June } 1992- \\
\text { Sept. } 1997\end{array}$ & 56.3 & 65.8 & $(1997)$ & 36.4 & $(1995)$ & 2.05 & 27.80 & $\begin{array}{l}\text { Discharge affected by regulations from Lakes } \\
\text { Carasaljo, Manetta, and Shenandoah. }\end{array}$ \\
\hline $\begin{array}{l}\text { Toms River near Toms River, } \\
\text { N.J. } 01408500\end{array}$ & Ocean & 123 & $\begin{array}{l}\text { Oct. 1928-Sept. } \\
1997\end{array}$ & 212 & 335 & $(1978)$ & 128 & $(1995)$ & 1.72 & 23.41 & $\begin{array}{l}\text { Discharge affected by diversions upstream } \\
\text { from gage. }\end{array}$ \\
\hline \multicolumn{12}{|c|}{ WATER MANAGEMENT AREA 14 - MULLICA AND WADING RIVERS } \\
\hline $\begin{array}{l}\text { Mullica River near Batsto, N.J. } \\
01409400\end{array}$ & Atlantic & 46.7 & $\begin{array}{l}\text { Sept. 1957-Sept. } \\
1997\end{array}$ & 107 & 168 & $(1973)$ & 50.4 & $(1966)$ & 2.29 & 31.11 & $\begin{array}{l}\text { Discharge affected by some regulation, by } \\
\text { cranberry bogs and Lake Atsion. Inflow from } \\
\text { Sleeper Branch substantially increases dis- } \\
\text { charge. }\end{array}$ \\
\hline $\begin{array}{l}\text { Batsto River at Batsto, N.J. } \\
01409500\end{array}$ & Burlington & 67.8 & $\begin{array}{l}\text { Oct. 1927-Sept. } \\
1997\end{array}$ & 122 & 193 & $(1958)$ & 66.2 & $(1966)$ & 1.80 & 24.46 & Discharge regulated by Batsto Lake. \\
\hline $\begin{array}{l}\text { Oswego River at Harrisville, } \\
\text { N.J. }\end{array}$ & Burlington & 72.5 & $\begin{array}{l}\text { Oct. 1930-Sept. } \\
1997\end{array}$ & 86.5 & 138 & $(1978)$ & 41.4 & $(1966)$ & 1.19 & 16.21 & $\begin{array}{l}\text { Discharge regulated by Harrisville Pond and } \\
\text { ponds and cranberry bogs upstream. Dis- } \\
\text { charge probably reduced by ground-water } \\
\text { outflow to nearby surface drainage basins } \\
\text { such as Oyster Creek. }\end{array}$ \\
\hline $\begin{array}{l}\text { East Branch Bass River near } \\
\text { New Gretna, N.J. } 01410150 \\
\end{array}$ & Burlington & 8.11 & $\begin{array}{l}\text { Jan. 1978-Sept. } \\
1997\end{array}$ & 15.8 & 23.2 & $(1997)$ & 9.60 & $(1985)$ & 1.95 & 26.54 & $\begin{array}{l}\text { Discharge affected by some regulation from } \\
\text { Lake Absagami. }\end{array}$ \\
\hline \multicolumn{12}{|c|}{ WATER MANAGEMENT AREA 15 - GREAT EGG HARBOR AND TUCKAHOE RIVERS } \\
\hline $\begin{array}{l}\text { Great Egg Harbor River near } \\
\text { Sicklerville, N.J. } 01410784\end{array}$ & Camden & 15.1 & $\begin{array}{l}\text { Mar. 1996-Sept. } \\
1997\end{array}$ & 20.6 & 20.6 & $(1997)$ & 20.6 & $(1997)$ & 1.36 & 18.51 & \\
\hline $\begin{array}{l}\text { Great Egg Harbor River near } \\
\text { Folsom, N.J. } 01411000\end{array}$ & Atlantic & 57.1 & $\begin{array}{l}\text { September } 1925- \\
\text { Sept. } 1997\end{array}$ & 86.1 & 133 & $(1973)$ & 44.4 & $(1931)$ & 1.51 & 20.48 & \\
\hline $\begin{array}{l}\text { Tuckahoe River at Head of } \\
\text { River, N.J. } 01411300\end{array}$ & Cape May & 30.8 & $\begin{array}{l}\text { December 1969- } \\
\text { Sept. } 1997\end{array}$ & 43.2 & 64.3 & $(1984)$ & 21.7 & (1995) & 1.40 & 19.04 & $\begin{array}{l}\text { Discharge affected by occasional regulation } \\
\text { from pond upstream. }\end{array}$ \\
\hline
\end{tabular}


Table 4. Selected information for continuous streamflow-gaging stations in New Jersey ${ }^{1}$ through water year 1997--Continued

\begin{tabular}{|c|c|c|c|c|c|c|c|c|c|}
\hline \multirow[b]{2}{*}{$\begin{array}{c}\text { U.S. Geological Survey } \\
\text { streamflow-gaging station } \\
\text { name and number }\end{array}$} & \multirow[b]{2}{*}{ County } & \multirow[b]{2}{*}{$\begin{array}{l}\text { Drain- } \\
\text { age area } \\
\text { (square } \\
\text { miles) }\end{array}$} & \multirow[b]{2}{*}{$\begin{array}{l}\text { Period of } \\
\text { record analyzed }\end{array}$} & \multicolumn{5}{|c|}{ Discharge, for period of record analyzed } & \multirow[b]{2}{*}{ Remarks } \\
\hline & & & & $\begin{array}{c}\text { Mean } \\
\text { annual } \\
\text { (cubic feet } \\
\text { per second) }\end{array}$ & $\begin{array}{l}\text { Highest annual } \\
\text { mean (cubic feet } \\
\text { per second; year } \\
\text { in parentheses) }\end{array}$ & $\begin{array}{l}\text { Lowest annual } \\
\text { mean (cubic feet } \\
\text { per second; year } \\
\text { in parentheses) }\end{array}$ & 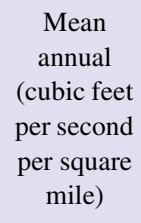 & $\begin{array}{c}\text { Mean } \\
\text { annual } \\
\text { (inches per } \\
\text { year over } \\
\text { drainage } \\
\text { area) }\end{array}$ & \\
\hline \multicolumn{10}{|c|}{ WATER MANAGEMENT AREA 17 - MAURICE, SALEM, AND COHANSEY RIVERS } \\
\hline $\begin{array}{l}\text { Little Ease Run near Clayton, } \\
\text { N.J. } 01411456\end{array}$ & Gloucester & 9.77 & $\begin{array}{l}\text { Feb 1988-Sept. } \\
1997\end{array}$ & 11.2 & $14.3 \quad(1997)$ & $5.7 \quad(1995)$ & 1.14 & 15.55 & $\begin{array}{l}\text { Discharge affected by occasional regulation } \\
\text { from unknown sources. }\end{array}$ \\
\hline $\begin{array}{l}\text { Maurice River at Norma, N.J. } \\
01411500\end{array}$ & Salem & 112 & $\begin{array}{l}\text { July 1932-Sept. } \\
1997\end{array}$ & 165 & $(1973)$ & $(1966)$ & 1.47 & 19.97 & $\begin{array}{l}\text { Discharge affected by occasional regulation } \\
\text { from ponds upstream. }\end{array}$ \\
\hline \multicolumn{10}{|c|}{ WATER MANAGEMENT AREA 18 - LOWER DELAWARE TRIBUTARIES } \\
\hline $\begin{array}{l}\text { Raccoon Creek near Swedes- } \\
\text { boro, N.J. } 01477120\end{array}$ & Gloucester & 26.9 & $\begin{array}{l}\text { May 1966-Sept. } \\
1997\end{array}$ & 40.6 & $64.7 \quad(1973)$ & $22.5 \quad(1981)$ & 1.51 & 20.50 & \\
\hline \multicolumn{10}{|c|}{ WATER MANAGEMENT AREA 19 - RANCOCAS CREEK } \\
\hline $\begin{array}{l}\text { McDonald Branch in Lebanon } \\
\text { State Forest, N.J. } 01466500\end{array}$ & Burlington & 2.35 & $\begin{array}{l}\text { Oct. 1953-Sept. } \\
1997\end{array}$ & 2.18 & $3.85(1973)$ & $1.17 \quad(1995)$ & .93 & 12.62 & $\begin{array}{l}\text { Hydrologic bench-mark station. Discharge } \\
\text { affected by ground-water leakage to deep } \\
\text { aquifers. }\end{array}$ \\
\hline $\begin{array}{l}\text { North Branch Rancocas Creek } \\
\text { at Pemberton, N.J. } 01467000\end{array}$ & Burlington & 118 & $\begin{array}{l}\text { Sept. 1921-Sept. } \\
1997\end{array}$ & 171 & $(1978)$ & $(1995)$ & 1.45 & 19.69 & $\begin{array}{l}\text { Discharge affected by diversions and regu- } \\
\text { lated occasionally from ponds and cranberry } \\
\text { bogs. }\end{array}$ \\
\hline $\begin{array}{l}\text { South Branch Pennsauken } \\
\text { Creek at Cherry Hill, N.J. } \\
01467081\end{array}$ & Camden & 8.98 & $\begin{array}{l}\text { Oct. 1967-Sept. } \\
\text { 1976, Oct. 1977- } \\
\text { Sept. } 1997\end{array}$ & 18.9 & $27.3 \quad(1978)$ & $(1995)$ & 2.10 & 28.56 & \\
\hline $\begin{array}{l}\text { Cooper River at Haddonfield, } \\
\text { N.J. } 01467150\end{array}$ & Camden & 17.0 & $\begin{array}{l}\text { Oct. 1963-Sept. } \\
1997\end{array}$ & 34.2 & $50.6 \quad(1973)$ & $(1995)$ & 2.01 & 27.34 & $\begin{array}{l}\text { Discharge affected by occasional regulation } \\
\text { from Kirkwood Lake, other small lakes, and } \\
\text { wastewater-treatment plants. }\end{array}$ \\
\hline \multicolumn{10}{|c|}{ WATER MANAGEMENT AREA 20 - CROSSWICKS CREEK } \\
\hline $\begin{array}{l}\text { Crosswicks Creek at Exton- } \\
\text { ville, N.J. } 01464500\end{array}$ & Mercer & 81.5 & $\begin{array}{l}\text { Aug. 1940-Oct. } \\
\text { 1951, Oct. 1952- } \\
\text { Sept. } 1997\end{array}$ & 135 & $225 \quad(1978)$ & $\begin{array}{ll}69.9 & (1995)\end{array}$ & 1.66 & 22.51 & $\begin{array}{l}\text { Discharge regulated occasionally by lakes } \\
\text { upstream. }\end{array}$ \\
\hline
\end{tabular}


Daily discharge at the streamflow-gaging station on the Toms River near Toms River, N.J., and monthly precipitation at the Toms River weather station for a 2-year period (1995-96) are shown in figure 20 . These 2 years were very different from each other--1995 was an extremely dry year with many water restrictions, and 1996 was one of the wettest years in recorded history. The long-term mean annual precipitation at the Toms River weather station is 47.14 inches and the long-term statewide mean annual precipitation is 44.67 inches (18971997) (National Oceanic and Atmospheric Administration, 1997). In 1995, the precipitation at the Toms River weather station totalled 38.27 inches, which is 85 percent of the long-term average at that station. Rainfall exceeded the monthly average in only 3 months that year--May, October, and November. The discharge at the streamflow-gaging station on the Toms River near Toms River, N.J., reflects the below-normal precipitation. Discharge for water year 1995 was $128 \mathrm{ft}^{3} / \mathrm{s}$ (cubic feet per second), compared to the long-term average of $212 \mathrm{ft}^{3} / \mathrm{s}$ for water years 1929-96 (table 4). Monthly mean discharges were below long-term averages for the entire year. Discharge decreased in response to the lack of rain from late winter through summer, reaching a low in mid-September. The increased precipitation in the fall (October and November) caused the discharge to increase (fig. 20). The monthly precipitation for November totalled 8.92 inches, almost 5 inches above normal, causing a peak discharge for the year of $701 \mathrm{ft}^{3} / \mathrm{s}$.

In contrast, 1996 was one of the wettest years on record. The Blizzard of ' 96 in early January left more than $2 \mathrm{ft}$ of snow in most of the State, and the melting of this snow caused widespread flooding (Reed and others, 1997). Precipitation in the Toms River Basin was higher than normal for 8 months of the year, which made flows in the Toms River higher than normal for the whole year. The annual mean discharge at the streamflow-gaging station on the Toms River near Toms River, N.J., in 1996 was $229 \mathrm{ft}^{3} / \mathrm{s}$, which is 108 percent of long-term mean annual discharge (Reed and others, 1997). Discharge was greater than normal from June through the end of the year and peaked in mid-October with a discharge of $770 \mathrm{ft}^{3} / \mathrm{s}$ from a storm on October 19-20 (Reed and others, 1997).

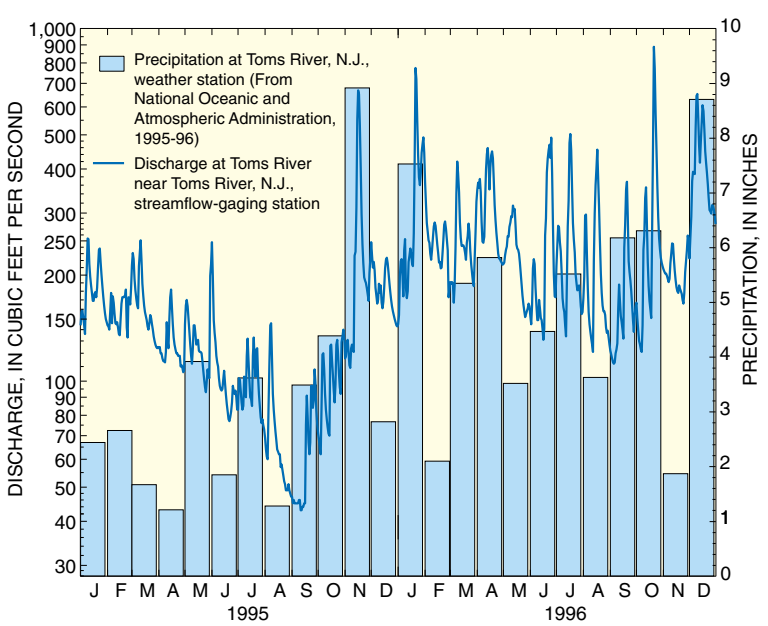

Figure 20. Relation of daily mean discharge at the Toms River near Toms River, N.J., streamflow-gaging station to monthly precipitation at the Toms River, N.J., weather station. Streamflow and precipitation are closely related. Because 1995 was an extremely dry year, stream discharge declined to less than 50 cubic feet per second by September. Higher precipitation amounts in October and November, however, caused discharge to increase to nearly 700 cubic feet per second in November. 1996, in contrast, was one of the wettest years on record. The blizzard of January 1996 and the accompanying snowmelt caused discharge to approach 800 cubic feet per second. Many months of record rainfall maintained streamflow at high levels throughout the year. 


\section{The flow of water past a point on a stream is measured at a streamflow-gaging station. Streamflow records integrate the effects of climate, topography, and geology, and show the distribution and magnitude of runoff in time.}

\section{Flow-duration curves}

The flow of water past a point on a stream is measured at a streamflow-gaging station. Streamflow records integrate the effects of climate, topography, and geology, and show the distribution and magnitude of runoff in time. Streamflow characteristics of a gaging station can be summarized by constructing a flow-duration curve, which is a graph that shows the percentage of time a given flow at a given point on a stream is either equalled or exceeded (Searcy, 1959). Flow-duration curves can be constructed from either daily or annual discharge measurements. If the curves are constructed by using units of cubic feet per second per square mile of drainage area, the characteristics of watersheds of different sizes can be compared. The shape of a flowduration curve reveals important information about the hydrologic and geologic characteristics of a basin. Steeply sloping flow-duration curves indicate streams with highly variable flow derived mostly from overland runoff; more gently sloping flowduration curves indicate streams with more constant flow derived mostly from ground-water storage.

Four flow-duration curves, each from a stream in a different physiographic province in New Jersey, are shown in figure 21 . The slope of the flow-duration curve for Stony Brook at Princeton, N.J., in the Piedmont Physiographic Province is steep, indicating highly variable flow. The Piedmont Physiographic Province is rocky, with thin soils and little ground-water storage capacity, and most precipitation runs off to streams. Therefore, streamflow is composed mainly of overland runoff with little ground-water discharge. Because streamflow depends mainly on precipitation rather than the steady contribution of ground water, it tends to be highly variable. The flow-duration curve for the Great Egg Harbor River at Folsom, N.J., in the Coastal Plain Physiographic Province is relatively flat, indicating significant ground-water storage in thick deposits of sand and in wetlands. The Coastal Plain Physiographic Province is sandy; therefore, little water runs overland to streams and most infiltrates into the ground and recharges the aquifer, which leads to a steady ground-water contribution to streams and thus stable streamflow (Fetter, 1980). The slopes of the flow-duration curves for Flat Brook near Flatbrookville, N.J., in the Valley and Ridge Physiographic Province, and South Branch Raritan River near High Bridge, N.J., in the New England Physiographic Province, are intermediate between the slopes of the curves for Stony Brook and Great Egg Harbor River, indicating that streamflow consists of a more even balance of ground-water discharge stored in sedimentary rocks and glacial deposits and overland runoff derived from precipitation.

The information provided by flow-duration curves is important to planners and developers. It can be used for predicting floods; to locate industries; for geologic, water-supply, and water-quality studies; and to analyze the availability and variability of streamflow. When based on many years of record, these curves can indicate the probable future behavior of a stream given that the physical characteristics of the basin will not be significantly altered (Gillespie and Schopp, 1982). 


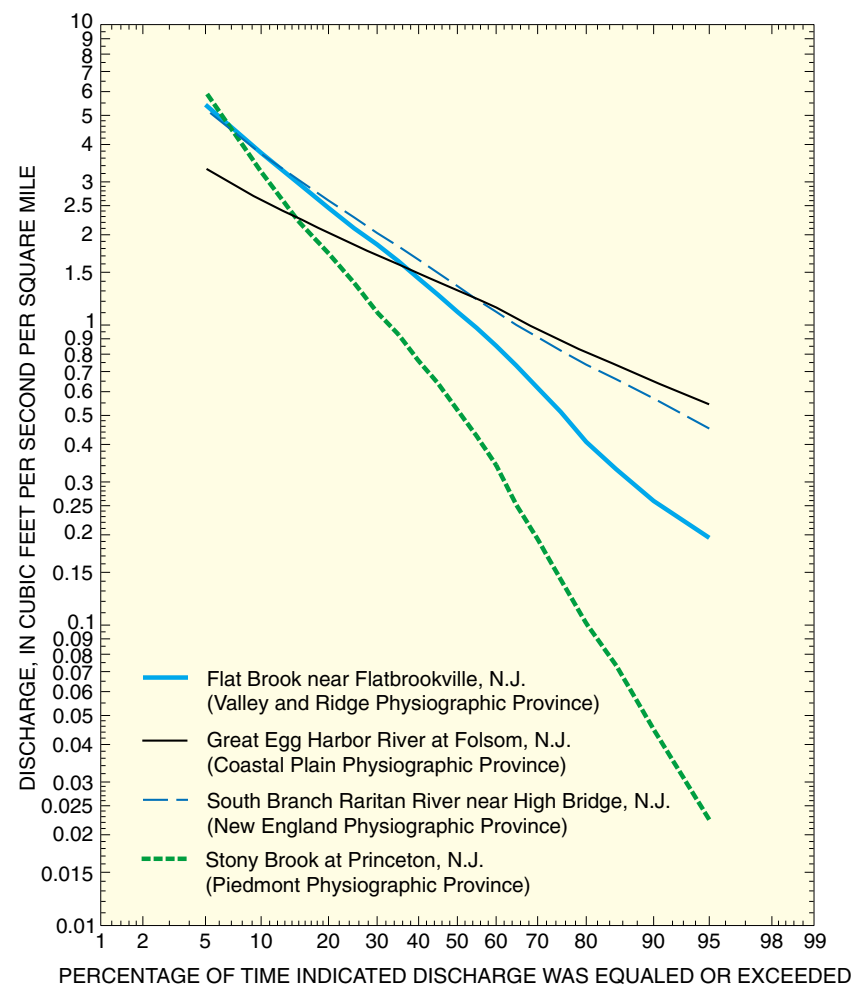

Figure 21. Flow-duration curves for four stream sites in different physiographic provinces in New Jersey. The shape of a stream's flow-duration curve depends on the geologic and hydrologic characteristics of its drainage basin. Areas that are rocky and have thin soils have little ground-water storage; therefore, streams in these areas, such as the Piedmont Physiographic Province, have steeply sloping flowduration curves. Areas that have thick deposits of sand and gravel have substantial ground-water storage; therefore, streams in these areas, such as the Coastal Plain Physiographic Province, have relatively flat flow-duration curves. 


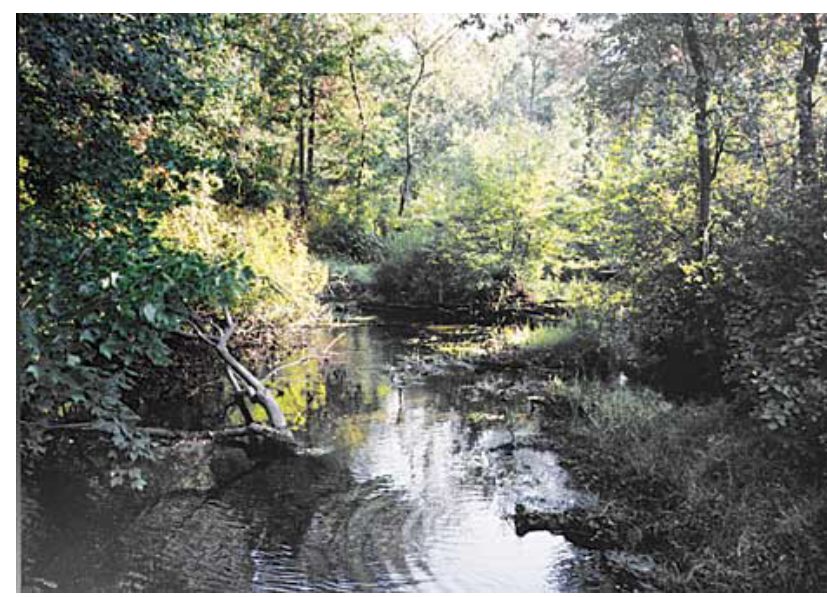

Great Egg Harbor River at Sicklerville, New Jersey, where ground-water discharge makes up roughly 85 percent of total streamflow. (Photograph by Jonathan Kennen)

\section{Base flow}

Streams in New Jersey always seem to flow, except during the driest periods. Although the water level may be low after a period of no precipitation, the stream still flows. Where does the water come from? Sustained, or fair-weather, streamflow is called base flow--which in most cases is simply the ground-water contribution to streamflow (groundwater discharge). Streamflow after a storm is composed of overland runoff, precipitation that falls directly onto the stream, interflow, and ground-water discharge. During fair weather, no precipitation is available; therefore, ground water discharged into the stream makes up streamflow. In some cases, such as where effluent from wastewater-treatment facilities or reservoir water is released into the stream to maintain a constant flow, base flow is composed not exclusively, but mainly, of ground-water discharge.

Base flow can be affected by various human activities. Withdrawals from the stream (for municipal use, irrigation, or cooling, for example) or discharges to the stream (industrial or wastewater discharge, for example) are the most common human activities that directly affect streamflow. Development of a watershed can affect base flow by removing wastewater from the basin; reducing the amount of recharge to the aquifer and, ultimately, the amount of ground water that discharges to the stream; and increasing ground-water withdrawals. Reduced base flow in turn may degrade or destroy the habitat for aquatic animals, reduce the amount of water available to dilute contaminants in the stream, and reduce the amount of water available to users downstream who depend on the stream for water supply.

In New Jersey, the amount of base flow in a stream depends mainly on the geology and degree of development in the watershed. In the Coastal Plain Physiographic Province, the ground-water contribution to streamflow ranges from about 65 to 95 percent. Base flow in streams in more highly developed areas or areas where sand deposits are thin or clay units are prevalent typically range from 65 to 75 percent. Many of these streams are located in the Lower Delaware water region. Base flow in streams in areas with thick sand and gravel deposits and little development, such as the Atlantic Coastal water region, is typically 80 to 95 percent. In northern New Jersey, where the geology is more variable, the range in the ground-water contribution to streamflow also is greater--22 to 88 percent $(\mathrm{CH} 2 \mathrm{M}$ Hill and others, 1992, Task 2 Report). In rocky areas with little or no sediment cover, the ground-water contribution to streamflow is small because ground-water storage capacity is minimal. In areas with thick glacial deposits and (or) carbonate rocks with solution channels that can store large amounts of ground water, the ground-water contribution to streamflow is large. (Base-flow values, except where noted, are compiled from Watt and Johnson, 1992; Watt and others, 1994; Johnson and Watt, 1996; Johnson and Charles, 1997; E.G. Charles, D.A. Storck, and R.M. Clawges, U.S. Geological Survey, written commun., 1999; A.C. Kane, E.G. Charles, and D.A. Storck, U.S. Geological Survey, written commun., 1999; and unpublished data on file at the U.S. Geological Survey District Office, West Trenton, New Jersey.) 


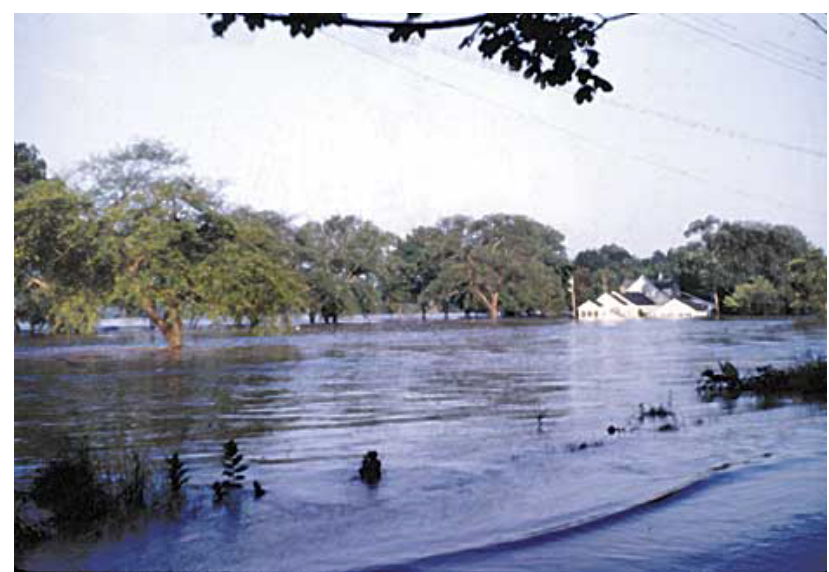

Flood on the Delaware River, Stacy Park, New Jersey, August 28, 1955. (Photograph by Jerry Ludlow)

\section{Flood-prone areas and wetlands}

Flooding has long been a problem in many areas of the State. Loss of lives and property due to flooding can be substantial. In New Jersey, precipitation is fairly evenly distributed throughout the year, but flooding tends to occur during winter and early spring as a result of widespread, steady rain of moderate intensity that falls on frozen ground and therefore cannot infiltrate. In addition, accumulated snow and ice may melt and increase runoff to the streams, increasing the chance of flooding. Summer storms tend to be more short-lived and of greater intensity. Summer thunderstorms typically are of local extent and may cause small streams to flood. Major floods of great magnitude and areal extent that resulted in loss of life and property hit New Jersey in 1903, $1940,1955,1971$, and 1984. Of these, the first four were caused by summer storms; the 1984 flood was caused by a spring storm. (See U.S. Geological Survey, 1991.)

Because parts of New Jersey are densely populated, flood planning is a necessity. Flood-warning systems and knowledge of flood-prone areas are essential for protecting lives and property. In New Jersey, the USGS, in cooperation with Somerset County, the National Weather Service, and the U.S. Army Corps of Engineers, has implemented floodwarning systems in the Passaic River Basin, in Som- erset County, and in several small watersheds (fig. 19). These flood-warning systems consist of streamflow-gaging stations and precipitation gages that continuously monitor streamflow and rainfall. These data are transmitted by radio, telephone, and satellite to officials to alert them to any threat of flooding. Streamflow-gaging stations and precipitation stations are distributed throughout the watersheds and at critical flood-prone locations to provide the best real-time information available to predict flooding. These data allow for efficient emergency evacuations of high-risk areas. Hydrologic data gathered from this network of sites also are useful for planning for future water-supply needs, assisting in monitoring surface-water quality, responding early to hazardous-waste spills, planning for environmental concerns and development, and optimizing the design of bridges, dams, and levees (Summer, 1998b, 1998c).

To minimize the effects of flooding, State and local governments regulate development in floodplains. In New Jersey, the NJDEP distributes flood maps and flood-elevation data, provides flood-preparedness and flood-recovery assistance, regulates floodplain development through permits, and coordinates the National Flood Insurance Program operated by the Federal Emergency Management Agency (FEMA). FEMA produces maps of "special floodhazard areas" in a community. These are areas that are subject to inundation during the 100-year and 500-year floods (Federal Emergency Management Agency, 1988). The 100-year flood is a flood that has a 1-percent probability of being equalled or exceeded during any given year. This is the National standard on which floodplain management and insurance requirements are based (Federal Emergency Management Agency, 1988). The 500-year flood is a flood with a 0.2-percent chance of being equalled or exceeded in any given year. Mapping the 500 -year flood is for information purposes and chances of flooding outside the 500-year flood designation are considered to be very small. 
Wetlands are unique surface-water features that are found throughout New Jersey but predominantly in the Coastal Plain (figs. 2a-e). Wetlands form where water is at or near the land surface, most commonly along rivers and in low-lying coastal areas. They are characterized by particular types of vegetation and (or) soils. In inland areas, impervious clays can restrict vertical movement of water and wetlands can be formed. Wetlands can receive water from the surrounding area, can recharge the surrounding area, or both (Winter and others, 1998) (fig. 22 ). Wetlands are beneficial in many ways. They provide spawning areas for fish and shellfish; food and migrating and wintering locations for birds; and homes, food, and shelter for animals (beavers, foxes, rabbits, and mice) and reptiles (U.S. Geological Survey, 1996c). Wetlands also provide flood- and stormdamage protection, erosion control, and public water supply, and support production of economically important crops such as blueberries, cranberries, wild rice, salt hay, and timber (U.S. Geological Survey, 1996c). Wetlands also act as water-quality "filters" by absorbing nutrients, trace elements, and other contaminants from the water that flows through them, and are recreational areas for boating, hunting, painting, and photography (U.S. Geological Survey, 1996c).
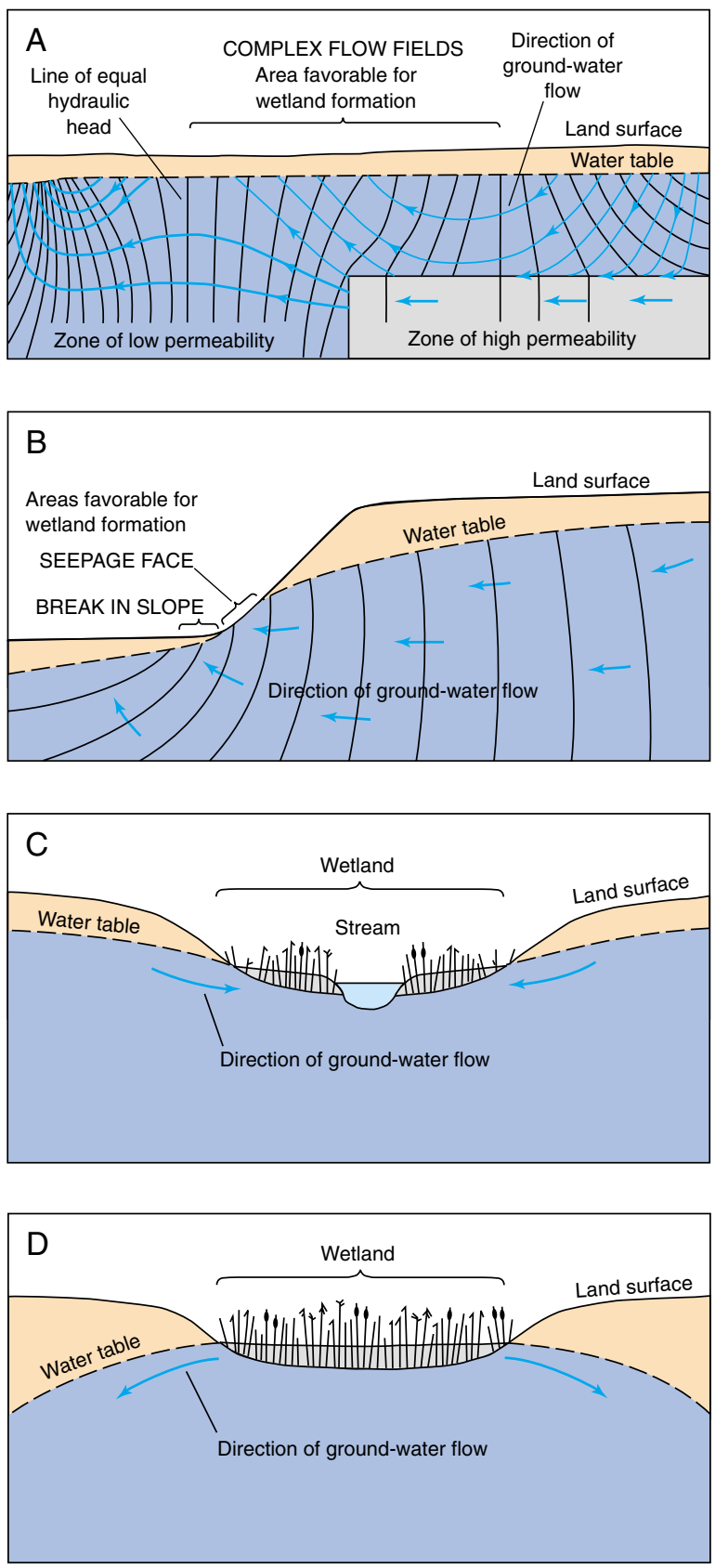

Figure 22. Schematic diagrams showing groundwater flow associated with wetlands. The source of water to wetlands can be $(A)$ ground-water discharge where the land surface is underlain by complex ground-water flow fields, (B) ground-water discharge at seepage faces and at breaks in slope of the water table, (C) streams, and (D) precipitation where wetlands have no stream inflow and the water table slopes away from the wetland. (From Winter and others, 1998) 
In New Jersey, wetlands have been destroyed to provide land for crop production, housing, industrial development, transportation, and landfills. The quality of the water in wetlands has been degraded by agriculture, logging, industrial discharge, municipal waste, and urban runoff. Federal and State government and private organizations are working to restore and maintain the integrity of the State's wetlands.

\section{Lakes and reservoirs}

New Jersey has 1,200 lakes, including 380 public lakes that occupy a total of 24,000 acres (fig. 2a-e). Many of New Jersey's lakes are natural, but many others, both public and private, are impoundments on streams. Public lakes may be used for recreational purposes such as swimming, boating, and fishing for both native and stocked species (N.J. Department of Environmental Protection, Environmental Indicators Technical Reports, June 1998, accessed March 23, 2000, on the World Wide Web at URL http://www.state.nj.us/dep/dsr/ neppspub3.htm\#WATERRESOURCESSECTION, text format).

Lakes, like wetlands and streams, interact with the ground-water system (table 5). Some lakes receive ground-water inflow over their entire bed, some have seepage loss to ground water over their entire bed, and some receive inflow through part of their bed and have seepage loss to ground water through other parts (Winter and others, 1998). Reservoirs are man-made structures built along streams, typically for water-supply or water-storage purposes. Lakes and reservoirs, unlike streams, are greatly affected by evaporation because of their large surface areas. Water levels in reservoirs and streams can change rapidly, whereas those in lakes tend to be fairly stable. The USGS measures and reports the stage and change in contents in selected lakes and reservoirs throughout the State.

Organic deposits that line the beds of lakes and reservoirs affect the distribution of the seepage and the chemical reactions that occur between the sediments and water (Winter and others, 1998). Large concentrations of nutrients, such as nitrogen and phosphorus, that typically enter a lake in runoff from urban and agricultural areas can, over a long period of time, adversely affect the quality of water in lakes and eventually render them unusable for water supply and (or) recreation. This process, called eutrophication, occurs naturally but can be accelerated as a result of the inputs of large amounts or excessive concentrations of nutrients and suspended sediments from point and nonpoint sources. Eutrophic lakes are characterized by high concentrations of suspended sediments, nutrients, and algae. Excessive plant growth may be present, and fish kills may occur as a result of fluctuations in concentrations of dissolved oxygen. 
Table 5. Characteristics of surface-water bodies

\begin{tabular}{l|c|c|c|c}
\hline \multicolumn{1}{c|}{ Characteristic } & Stream & Lake & Reservoir & Wetland \\
\hline Interacts with ground-water system & $\mathrm{x}$ & $\mathrm{x}$ & $\mathrm{x}$ & $\mathrm{x}$ \\
Human-made structure & & & $\mathrm{x}$ & \\
Greatly affected by evaporation & & $\mathrm{x}$ & $\mathrm{x}$ & $\mathrm{x}$ \\
Water level changes rapidly & $\mathrm{x}$ & & $\mathrm{x}$ & \\
Organic deposits line bottom & & $\mathrm{x}$ & $\mathrm{x}$ & $\mathrm{x}$ \\
\hline
\end{tabular}

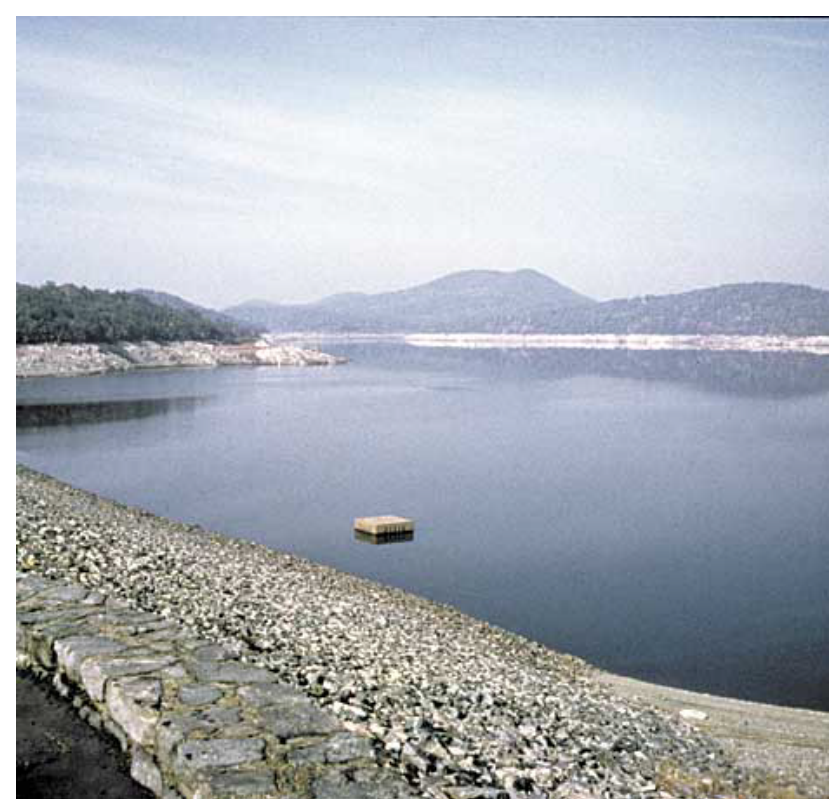

Wanaque Reservoir, New Jersey. (File photograph, U.S. Geological Survey, West Trenton, New Jersey) 


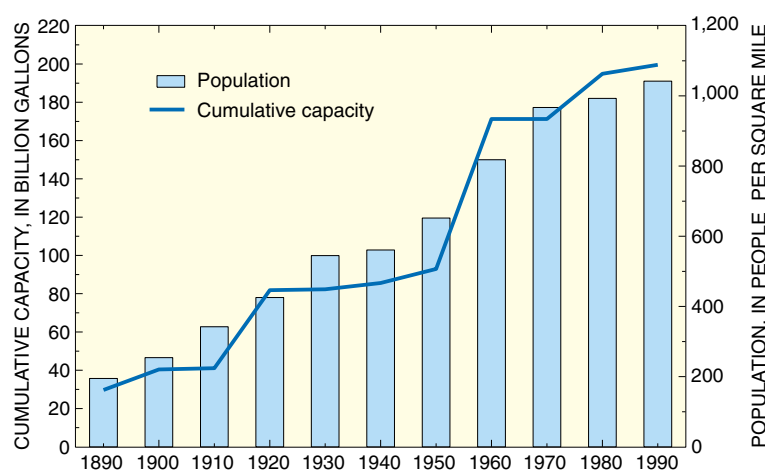

Figure 23. Cumulative capacity of selected large reservoirs and lakes and population of New Jersey from 1890 to 1990 . The need for increased reservoir capacity is a result of the growth in population. The aquifers, especially those in northern New Jersey, yield significant amounts of water but are unable to meet the demands of the growing population, making the reservoirs a crucial part of New Jersey's overall water-supply plan.
As part of the Clean Lakes Program, the NJDEP Bureau of Freshwater and Biological Monitoring has evaluated the condition of 116 public lakes with known water-quality problems or whose water quality was previously unknown. Of the 116 lakes evaluated, 113 are considered to be eutrophic. Lakes that are found to be eutrophic may be treated, typically by dredging and (or) application of aquatic pesticides, to restore their aesthetic and recreational value. (See N.J. Department of Environmental Protection, Environmental Indicators Technical Reports, June 1998, accessed March 23, 2000, on the World Wide Web at URL http://www.state.nj.us/dep/ dsr/neppspub3.htm\#WATERRESOURCESSECTION, text format).

The locations of New Jersey's major reservoirs are shown in figure 6; selected information about them is listed in table 1 . The cumulative capacity of the lakes and reservoirs in New Jersey is shown in figure 23. Since 1900, the total capacity of all the reservoirs has increased from roughly 30 to 200 billion gallons. The need for surface-water storage has increased along with the State's population.

Although the aquifers in northern New Jersey can provide significant amounts of ground water, their yield is insufficient to meet the needs of the public (U.S. Geological Survey, 1990); therefore, reservoirs are a necessity. 


\section{Ground-Water Data}

\section{Ground-water levels}

The USGS maintains a network of observation wells in New Jersey for the purpose of monitoring ground-water levels throughout the State. Changes in water levels reflect the general response of the ground-water system to natural climate changes, changes in recharge patterns, and ground-water withdrawals. Automatic water-level recorders are used on some of the wells to obtain the continuous, long-term record that is needed to evaluate the effects of climate changes on the ground-water system, to develop a data base that can be used to measure the effects of development, to facilitate the prediction of future ground-water supplies, and to provide data for ground-water-resource management (Jones and DeLuca, 1998). Ground-water levels typically are measured in about 200 wells throughout the State during any given year (fig. 24). Roughly 25 percent of the wells are completed in stratified drift or shale, siltstone, sandstone, limestone, dolomite, and conglomerate rock units in the northern physiographic provinces. Of the 25 percent, half are completed in the stratified drift and half are completed in the consolidated-rock aquifers. Wells completed in stratified drift range from 50 to $200 \mathrm{ft}$ in depth; wells completed in consolidated-rock aquifers range from 20 to about $700 \mathrm{ft}$ in depth. Seventy-five percent of the ground-water observation wells in New Jersey are in the Coastal Plain Physiographic Province. About 30 percent of the wells in the Coastal Plain are completed in unconfined aquifers. The KirkwoodCohansey aquifer system is the most heavily monitored, but water levels also are measured in wells completed in the Holly Beach water-bearing zone, a minor unconfined aquifer in Cape May County. Water levels are measured in wells completed in the typically confined upper and middle Potomac-Raritan-Magothy aquifers and the Englishtown aquifer system where they reach the land surface (crop out) and are unconfined. About 70 percent of the wells in the Coastal Plain are completed in confined aquifers. Wells are completed in the confined Piney Point, Vincentown, and Wenonah-Mount Laurel aquifers and the Kirkwood-Cohansey, Englishtown, and Potomac-Raritan-Magothy aquifer systems. The depths of the observation wells in the Coastal Plain range from about $10 \mathrm{ft}$ in the Kirkwood-Cohansey aquifer system to more than 2,000 ft in the PotomacRaritan-Magothy aquifer system. One well, 5.3 miles offshore from Atlantic City, was drilled in 1986 to gather information on fresh-ground-water levels and salinity (chloride concentrations) off the Atlantic City coast.

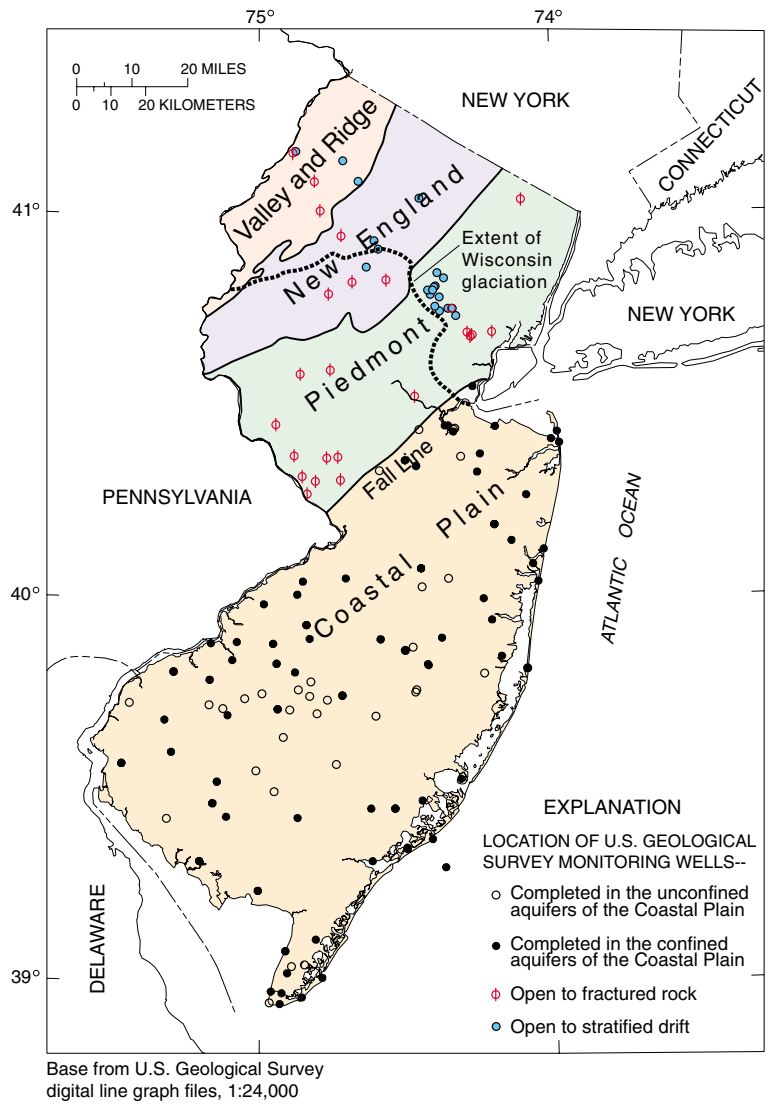

Figure 24. U.S. Geological Survey ground-water monitoring wells active in New Jersey in 1997. Water levels in these wells are monitored to evaluate the effects of development and climatic changes on the ground-water system. Long-term water-level measurements also can assist in the prediction of future ground-water availability and supply data for ground-water-resource management. 


\section{Changes in water levels reflect the general response of the ground-water system to natural climate changes, changes in recharge patterns, and ground-water withdrawals.}

Two water-level hydrographs--one for a well that is completed in the unconfined KirkwoodCohansey aquifer system and the other for a well that is completed in the confined Potomac-Raritan-Magothy aquifer system--are shown in figure 25 . The water level in the well that is completed in the unconfined aquifer system varies more because it rises in response to the infiltration of precipitation and falls with the discharge of ground water to surface-water bodies. The water level in the well that is completed in the unconfined aquifer system is affected more quickly than the water level in the well that is completed in the confined aquifer system by rainfall and climatic events such as long wet or dry periods. Water levels typically are highest in winter and early spring as a result of little or no evapotranspiration, low temperatures, and snowmelt and spring rains that recharge the aquifer. Ground-water levels typically start to decline as summer begins and continue to decline until late fall. Water use is highest in summer when more water is used for irrigation and recreation, and more water evaporates and transpires. Water levels typically are lowest in late fall, and rise again during winter, completing the cycle.
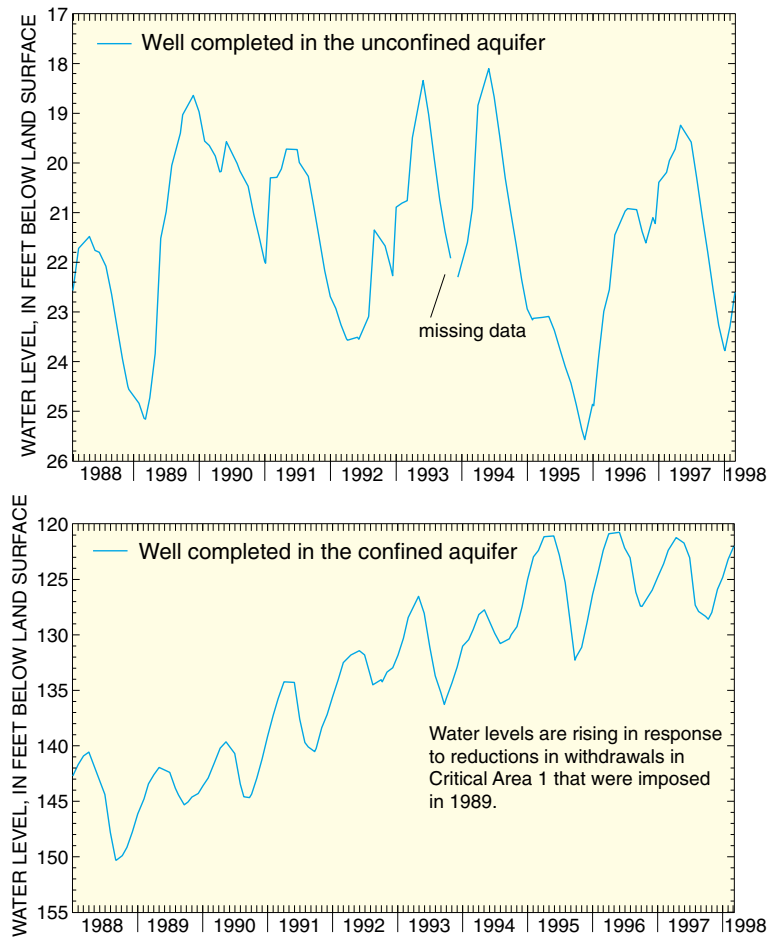

Figure 25. Hydrographs of water levels measured in observation wells in the Coastal Plain of New Jersey, 1988-98. Water levels in the well completed in the unconfined aquifer fluctuate rapidly because they rise and fall in response to climatic changes. Water levels in the well completed in the confined aquifer are buffered from short-term climatic changes; therefore, their response to precipitation is slow and they tend to rise and fall cyclically. 
In contrast, water levels in wells that are completed in confined aquifers tend to fluctuate less than those in wells that are completed in unconfined aquifers. Because confined aquifers are buffered from short-term climatic changes, their response to rainfall is more gradual. Changes in water levels in the heavily used Potomac-Raritan-Magothy aquifer system are caused primarily by ground-water withdrawals.

Water levels in observation wells are measured by different methods. About half the observation wells throughout the State are equipped with automatic recorders that record the water levels hourly. This type of data collection gives the most complete and accurate information of the methods used. A few wells are equipped with recorders that indicate only the maximum and minimum water level over a period of time. These water levels are not associated with any particular times other than the period between visits by USGS personnel. The water levels in the remaining one-quarter of the wells are measured manually two to six times per year. Measurement methods used in a given well may change over the period of record. Water-level measurements can be plotted on a map to obtain a regional perspective on water levels and to determine ground-water-flow directions. (See Box D.)

The USGS has documented the water levels in the confined aquifers of the New Jersey Coastal Plain on a regular basis since 1978. Every 5 years USGS personnel measure water levels in approximately 1,000 wells over a 4 - to 5-month period in late fall to assess the status of the water supply. Results of these studies have been used by NJDEP to develop withdrawal regulations and to establish the Water-Supply Critical Areas.

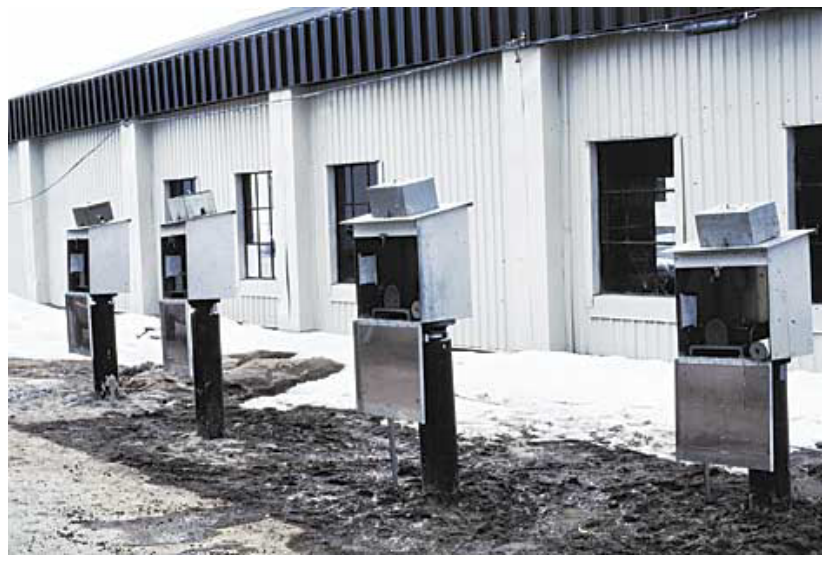

Four ground-water-monitoring recorders, each completed in a different hydrologic unit at Picatinny Arsenal, New Jersey. (Photograph by Eric Vowinkel) 


\section{$D$}

\section{Constructing a water-table or potentiometric-surface map}

Water levels in wells that are completed in an unconfined aquifer can be used to produce a water-table map, which is a representation of the configuration of the water table, or the top of the saturated zone. Similarly, water levels in wells that are completed in a confined aquifer can be used to produce a potentiometric-surface map, which is a representation of the aquifer's potentiometric surface, or the level to which water will rise in tightly cased wells (Fetter, 1980). The water table, then, is a particular type of potentiometric surface that occurs in an unconfined aquifer.

Water in a confined aquifer typically is under pressure. This causes the water in the well to rise to a level above the top of the aquifer. This type of well is called an artesian well. If the pressure is sufficient to cause water to flow from the well at land surface, the well is called a flowing artesian well.

The shape of the water table is controlled principally by the topography as the ground water flows from recharge areas (topographic highs) to discharge areas (topographic lows). The water table, therefore, tends to be a subdued replica of the topography. Streams also affect the shape of the water table. Where the water table intersects a stream channel, the water-table contour has a "v" shape. For a gaining stream--one that receives ground-water discharge-- the " $v$ " points upstream because water is flowing into the stream. For a losing stream--one that loses flow to the ground-water system--the " $v$ " points downstream because water is flowing into the stream banks. A potentiometric-surface map is much "smoother" than a water-table map because topography has little effect on water levels in a confined aquifer.

On water-table and potentiometric-surface maps, the direction of the ground-water flow typically is approximately perpendicular to the water-level contours. In northern New Jersey, however, where the rocks are fractured and folded, the direction of ground-water flow can be harder to determine. Because the ground-water system is dynamic, all water levels used to construct a water-level map should be measured at approximately the same time. 


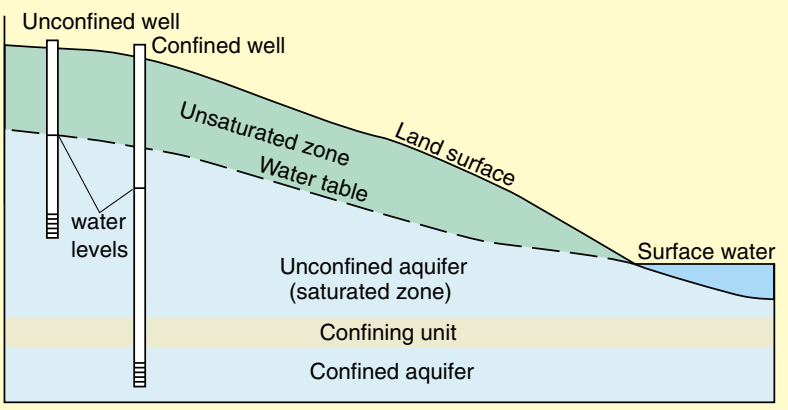

D-1. The water table is the upper surface of the saturated zone. The water table meets surface-water bodies at or near the shoreline if the surface-water body is connected to the ground-water system.

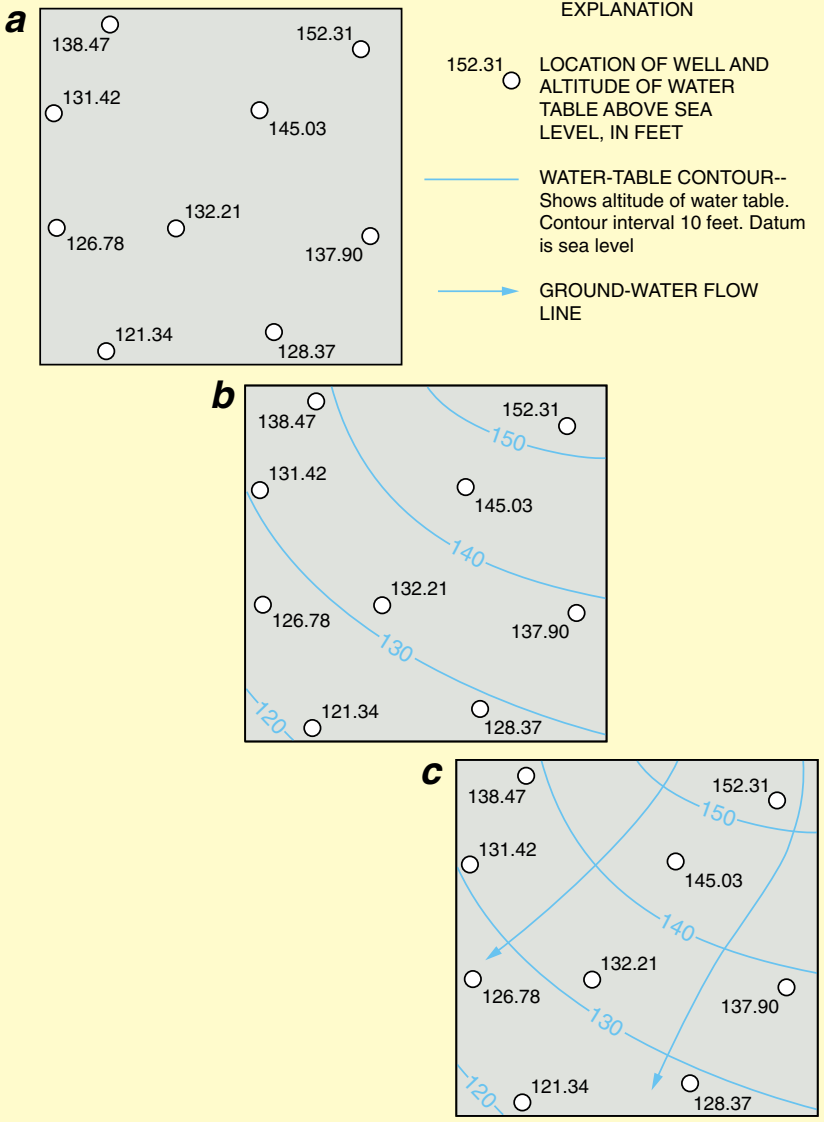

D-2. Using known altitudes of the water table at individual wells (a), contour maps of the water-table surface can be drawn $(\boldsymbol{b})$, and directions of ground-water flow along the water table can be determined (c) because ground-water flow is approximately perpendicular to the contours.

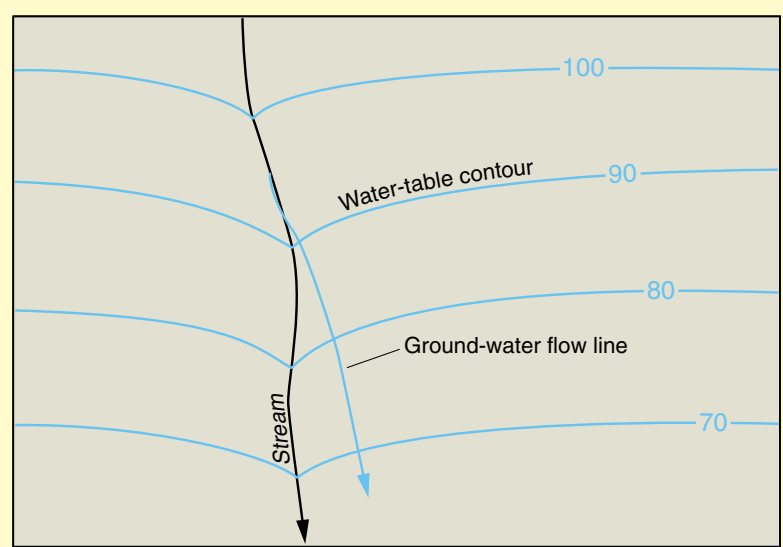

Losing streams lose water to the groundwater system (see fig. 4). This can be determined from water-table contour maps because the contour lines point downstream where they cross the stream.
D-3. Gaining streams receive water from the ground-water system (see fig. 4). This can be determined from water-table contour maps because the contour lines point upstream where they cross the stream.

(D-1) Water levels in unconfined and confined aquifers. (D-2) The making of a water-table map. (D-3) Examples of gaining and losing streams. (From Winter and others, 1998) 
In 1986, the NJDEP designated two WaterSupply Critical Areas in the New Jersey Coastal Plain (fig. 26). These areas were established in an attempt to manage withdrawals from aquifers in which water-level declines were a matter of concern. Withdrawals from specified aquifers were cut back and new allocations (with the exception of temporary construction dewatering and ground-water remediation activities) were limited. Critical Area 1 is located in Middlesex, Monmouth, and Ocean Counties. Withdrawals from the Wenonah-Mount Laurel aquifer, Englishtown aquifer system, and upper and middle Potomac-Raritan-Magothy aquifers in this area were restricted beginning in 1989. Early in water year 1991, long-term water-level declines began to reverse in observation wells that are completed in these aquifers in southern Monmouth and northern Ocean Counties. Ground-water withdrawals in this area were reduced and replaced by surface-water withdrawals for public supply or were shifted to shallower, unconfined aquifers. By water year 1997, water levels in the Potomac-Raritan-Magothy aquifer system were leveling off, but those in the Englishtown aquifer system and the Wenonah-Mount Laurel aquifer were continuing to rise in some places. The hydrograph in figure 25 is an example of the rise in water levels in the PotomacRaritan-Magothy aquifer system over time. (See Jones and DeLuca, 1998.)

Critical Area 2 is located in Camden, most of Burlington and Gloucester, and parts of Atlantic, Cumberland, Ocean, Monmouth, and Salem Counties. Restrictions have been imposed on withdrawals from the upper, middle, and lower Potomac-RaritanMagothy aquifers since 1996. Current data show that water-level declines in these aquifers have stopped. (See Jones and DeLuca, 1998.)

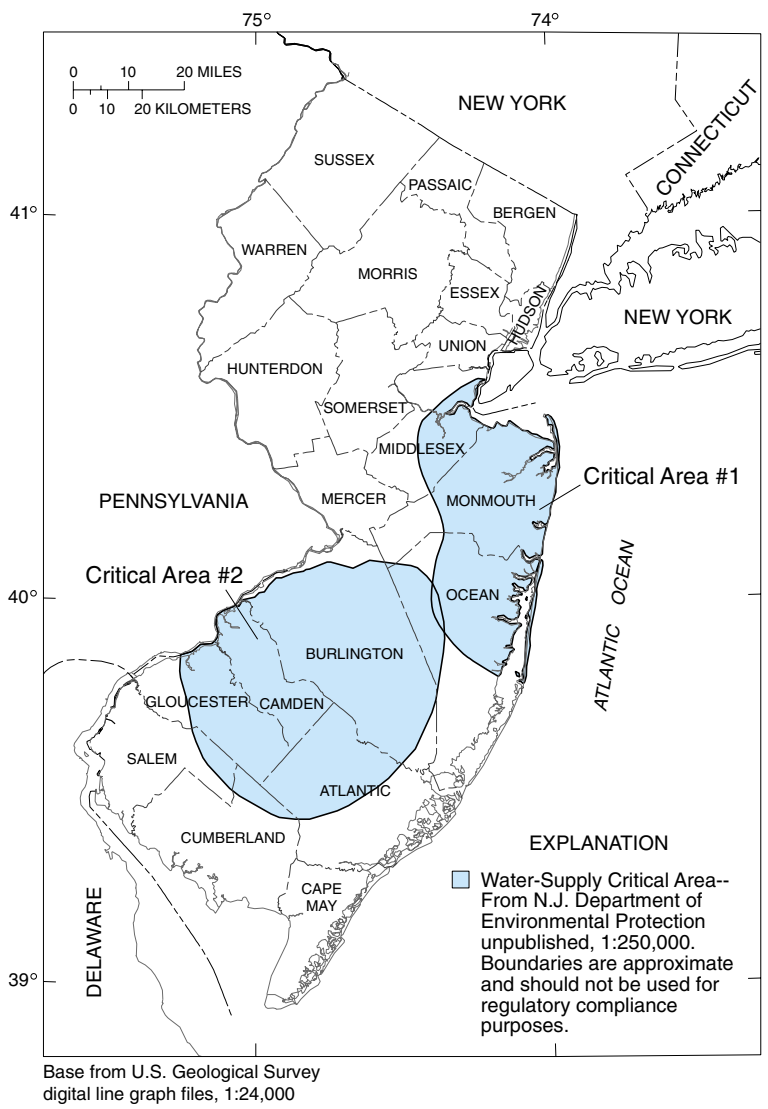

Figure 26. Location of Water-Supply Critical Areas in New Jersey. These areas were designated to help control the decline in water levels in some of the confined aquifers. Restrictions on withdrawals in Critical Area \#1 began in 1989, and water levels in some of the aquifers began to recover in 1991. Restrictions on withdrawals in Critical Area \#2 began in 1996, and water levels in some of the aquifers have since stabilized. 


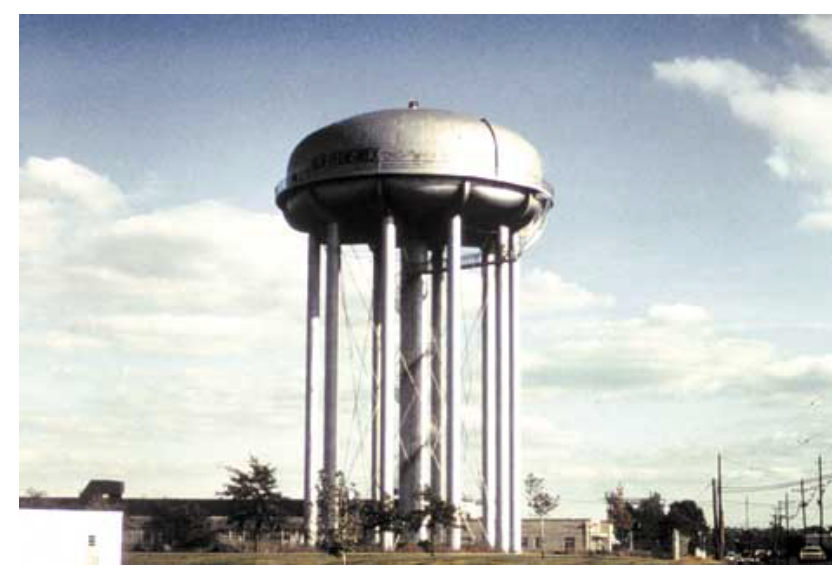

Water tower for public supply in central New Jersey. (Photograph by Eric Vowinkel)

\section{Major withdrawal wells}

Many large public supply wells are completed in aquifers in the New Jersey Coastal Plain (fig. 27). The volume of ground-water withdrawals depends on the extent of the aquifer, the population, and the presence of other sources of water.

The greatest withdrawals from a single aquifer in the Coastal Plain are from the unconfined Kirkwood-Cohansey aquifer system. Withdrawals from this aquifer system have increased since 1991 because of increased development, increased irrigated land, and restrictions on withdrawals from the deeper, confined aquifers (J.P. Nawyn, oral commun., 1999). Water is withdrawn from the Kirkwood-Cohansey aquifer system throughout the Coastal Plain, but withdrawals are concentrated in northern Ocean County and around the Atlantic City area. The withdrawals from each of the three aquifers of the Potomac-Raritan-Magothy aquifer system are nearly equal, and amount to roughly 60 percent of the volume withdrawn from the KirkwoodCohansey aquifer system. The Upper and Middle Potomac-Raritan-Magothy aquifers are used most heavily along the Delaware River near Camden and in the northern part of the Coastal Plain in Monmouth and Ocean Counties. The Lower PotomacRaritan-Magothy aquifer also is used heavily, but only around the Camden area. The areas in which water from the Potomac-Raritan-Magothy aquifer system is used most heavily correspond to the water- supply critical areas. Cutbacks in the withdrawals from these confined aquifers have been accompanied by increased withdrawals from the KirkwoodCohansey aquifer system. The Atlantic City 800-foot sand is used moderately along the coast. Withdrawals from this aquifer amount to about 30 percent of the volume withdrawn from the Kirkwood-Cohansey aquifer system. The Piney Point (not shown in figure 27) and Wenonah-Mount Laurel aquifers and the Englishtown aquifer system are the least used of the Coastal Plain aquifers. The combined withdrawals from these three aquifers are less than those from the Atlantic City 800-foot sand.

Ground-water withdrawals in northern New Jersey equal about 60 percent of the total withdrawals from the Coastal Plain aquifers. These withdrawals are shown by aquifer type in figure 28 . The glacial valley-fill aquifers, composed of stratified drift, are the most heavily used and most productive aquifers in northern New Jersey, accounting for more than 50 percent of the total ground-water withdrawals. Because glaciers covered and deposited sediments over most of northern New Jersey, these aquifers are found in all three of northern New Jersey's physiographic provinces. Withdrawals from the sandstone, shale, and mudstone aquifers in the Piedmont Physiographic Province account for more than 35 percent of the total ground-water withdrawals. The highest yielding aquifers are those that are composed of rocks that are highly weathered, jointed, and fractured. Crystalline-rock aquifers in the New England Physiographic Province and limestone and shale aquifers in the Valley and Ridge Physiographic Province account for only 10 percent of the total ground-water withdrawals in northern New Jersey. Limestone aquifers can produce significant amounts of water, especially when they are fractured, weathered, or covered by glacial material. Crystalline-rock and shale aquifers typically have low yields, except where they have been weathered and (or) fractured. 

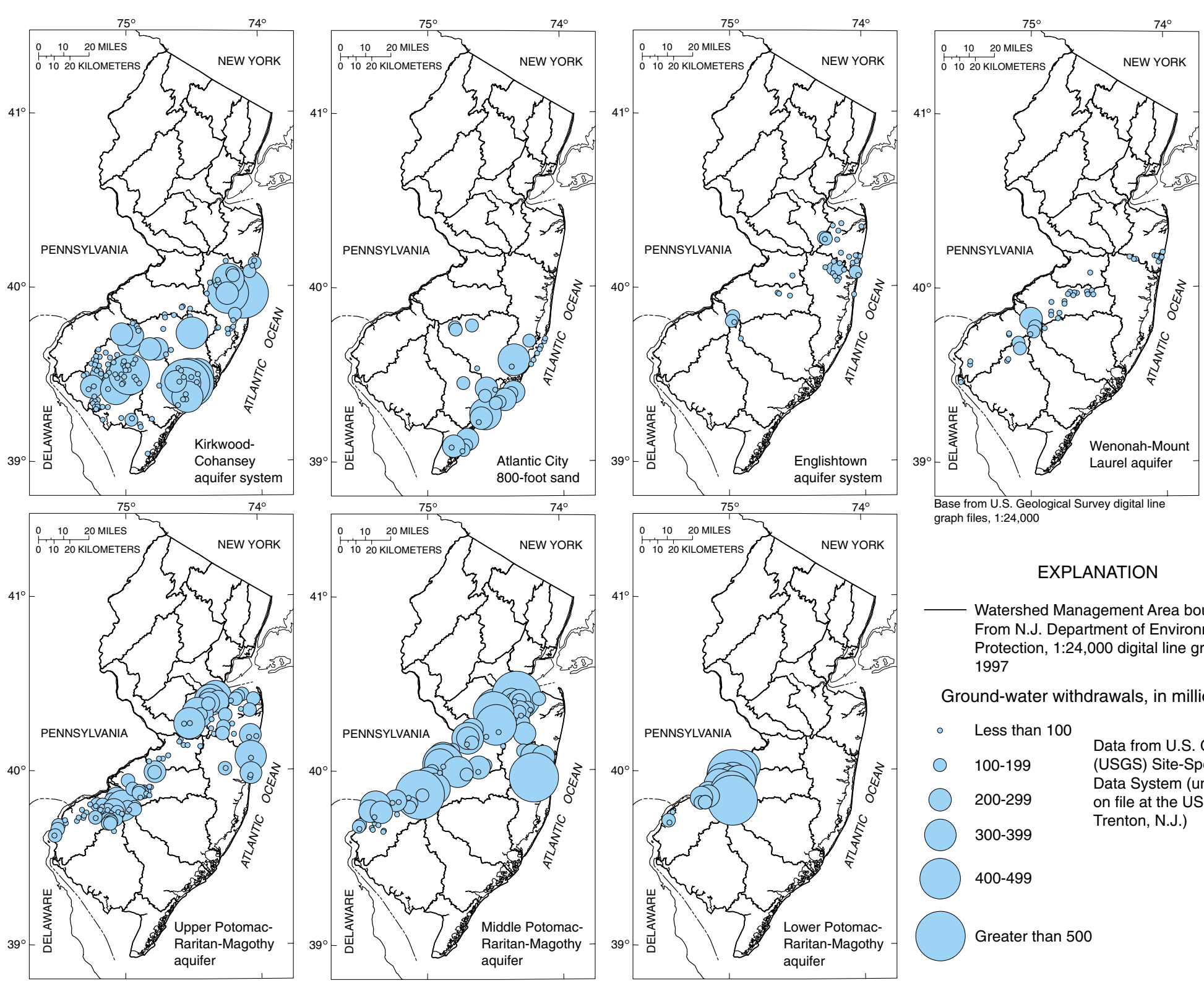

gase from files, 1:24, Geoo

\section{EXPLANATION}

- Watershed Management Area boundaryFrom N.J. Department of Environmental Protection, 1:24,000 digital line graph file, 1997

Ground-water withdrawals, in million gallons

- Less than 100

100-199 Data from U.S. Geological Survey

(USGS) Site-Specific Water Use

200-299 on file at the USGS office in West

300-399 Trenton, N.J.)

Figure 27. Location and amount of water withdrawn for public supply from the major aquifers in the Coastal Plain of New Jersey in 1997. Circles on the maps are centered on the locations of withdrawals from each of the aquifers. Water withdrawals from an aquifer depend on the location of the population to be served, the extent of the aquifer, how easily the water can be obtained, and the quality of the water. Each aquifer has a unique pattern of withdrawals related to these criteria. 


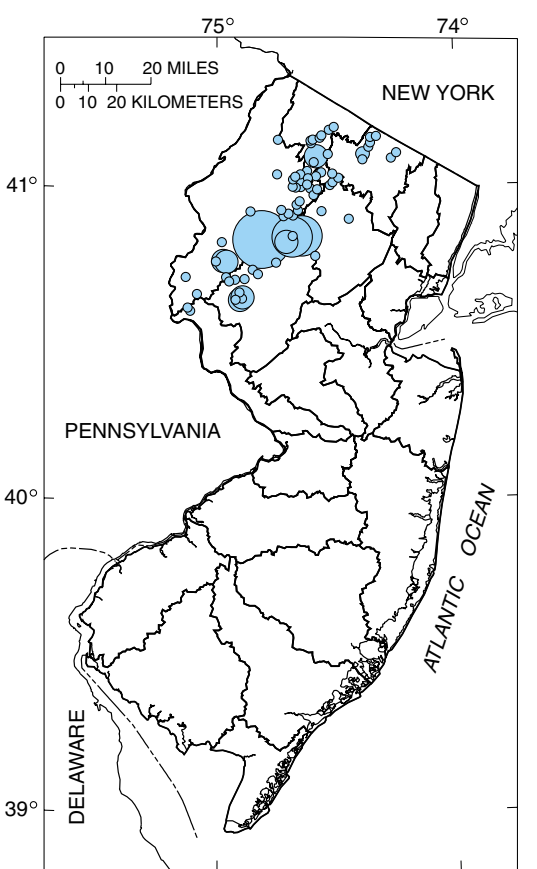

Crystalline, limestone, and shale aquifers (New England and Valley and Ridge Physiographic Provinces)

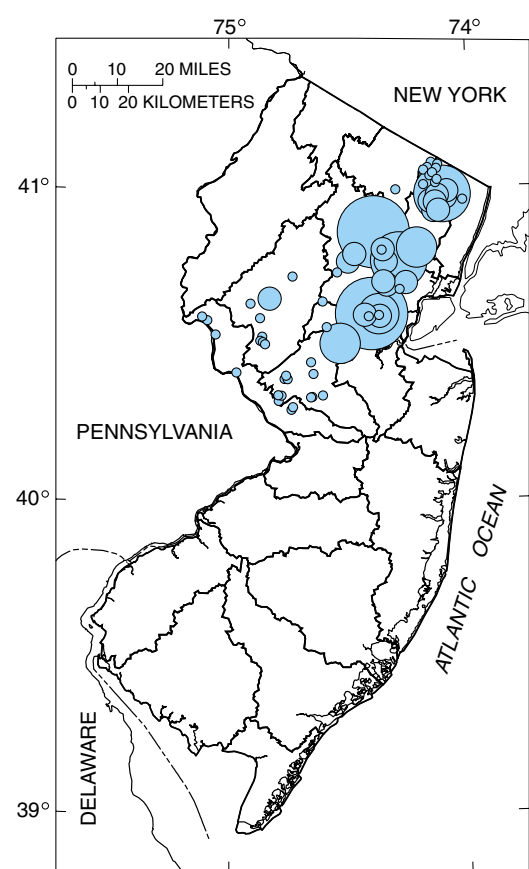

Sandstone, shale, and mudstone aquifers (Piedmont Physiographic Province)

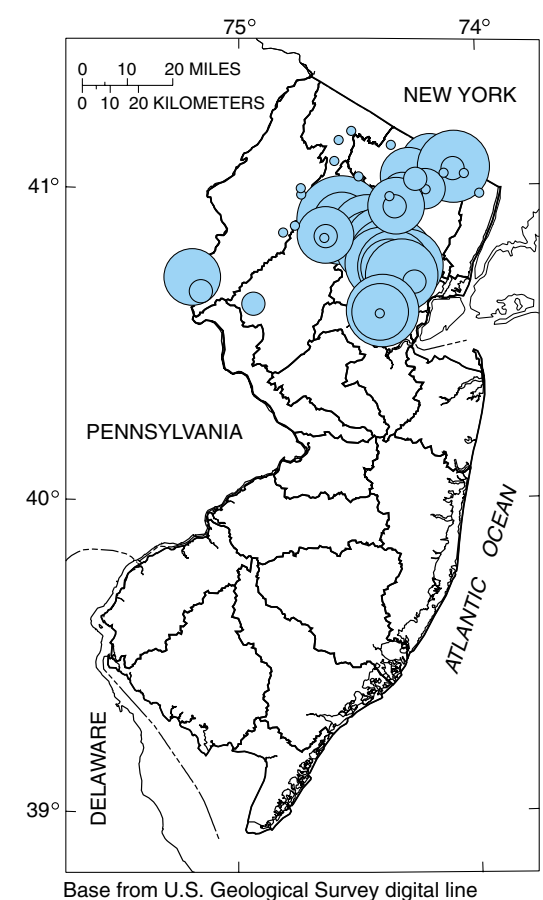

Base from U.S. Geo

Glacial valley-fill aquifers

(New England, Valley and Ridge, and Piedmont Physiographic Provinces)

\section{EXPLANATION}

Watershed Management Area boundary-From N.J. Department of Environmental Protection, 1:24,000 digital line graph file, 1997

Ground-water withdrawals, in million gallons

- Less than 100

(100-199

Data from U.S. Geological Survey

200-299 Data System (unpublished data on file at the USGS office in West 300-399 Trenton, N.J.)

400-499

Greater than 500

Figure 28. Location and amount of water withdrawn for public supply from aquifers in northern New Jersey in 1997. Circles on the maps are centered on the locations of withdrawals from each of the aquifer types. Water withdrawals from an aquifer depend on the location of the population to be served, the extent of the aquifer, how easily the water can be obtained, and the quality of the water. Withdrawals in the New England and Valley and Ridge Physiographic Provinces are primarily from crystalline aquifers and limestone and shale aquifers, respectively. Withdrawals in the Piedmont Physiographic Province are primarily from sandstone, shale, and mudstone aquifers. Glacial valley-fill aquifers cover all three physiographic provinces and supply the most water. 


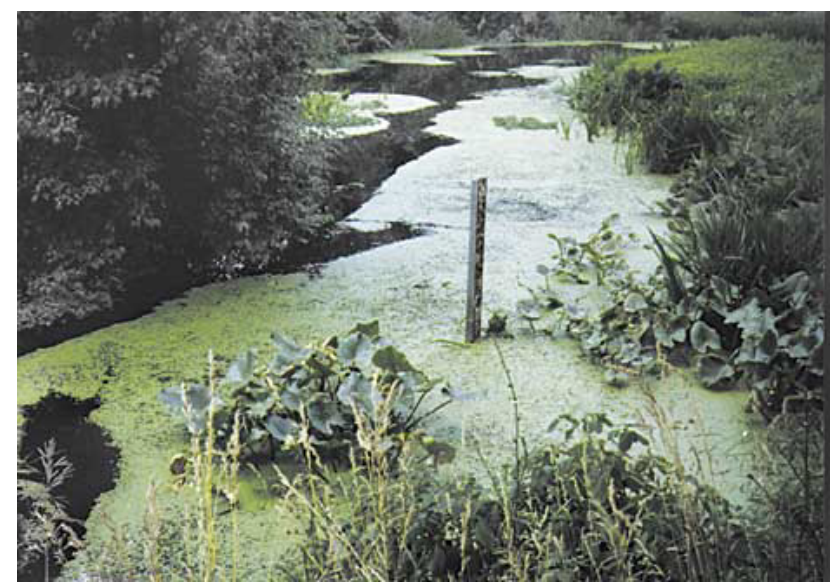

Excessive growth of Lemnaceae (duckweed) caused by excessive nutrient runoff, Lamington River at Ironia, New Jersey. (Photograph by Robert Nicholson)

\section{Water-Quality Data}

The ability of a water supply source to meet current and future demands depends not only on the quantity of water available but also on its quality. The quality of water that is unaffected by human activities is called "background" water quality. The addition of contaminants to the water supply alters the background water quality, and any substance that is present in the environment in concentrations greater than background levels can be considered to be a contaminant (Gough and others, 1993). The difference between background levels and those considered to constitute contamination can be very small.

Contaminants are derived from either "point" or "nonpoint" sources. Point sources, such as a chemical spill, effluent from a leaking septic tank, or discharge from an industrial facility or sewage-treatment plant, typically are relatively constant sources of a large quantity of contaminants in a readily identifiable location. Often these sources cause dramatic and immediate changes to the water quality. Nonpoint sources, such as lawns or farm fields to which pesticides or fertilizers have been applied, urban runoff, atmospheric deposition, or soil erosion, typically constitute smaller quantities of contaminants and are more diffuse and harder to identify than point sources. The effects of nonpoint-source contamination are usually subtle and gradual.
Contaminants can occur naturally (for example, radon) or be the result of human activities (for example, the application of pesticides). Radon is a radioactive gaseous element that occurs naturally in rocks and soils as a result of the radioactive decay of thorium and uranium--elements that are concentrated in rocks in certain parts of New Jersey (Gough and others, 1993). High concentrations of radon can cause health problems (U. S. Environmental Protection Agency, unpub. data titled Radon Health Risks, frequently asked questions, accessed January 21, 1999, on the World Wide Web at URL http:// www.epa.gov/iaq/radon/radonqa1.html, text format). Other naturally occurring contaminants include iron, which is not toxic to humans but can clog pipes, stain laundry, and discolor water when present in high concentrations. Sulfur is responsible for the "rotten egg" odor in some water supplies. Swamps and marshes commonly contain acidic and colored water, such as the "cedar waters" in the New Jersey Pinelands.

Contaminants that result from human activities or whose naturally occurring concentrations can be increased by human activities include pathogens (disease-causing microorganisms), nutrients, organic compounds, trace elements, sediment, and debris. Pathogens in our watersheds are bacteria and viruses that come from human and animal fecal waste. Faulty septic systems and leaking sewer lines, improper boat sanitation disposal, and wild, farm, and domestic animal waste all contribute to the problem. Pathogens can force us to close our beaches and restrict shellfish harvesting. Organic compounds such as pesticides, polychlorinated biphenyls (PCB's), oil, grease, gasoline, and chemicals used in our homes, gardens, and yards may be harmful to humans and aquatic life. Sources of trace elements include industrial-waste discharges, mining, acidrain drainage, and film-processing wastes (Manahan, 1990). Sediments include dirt, sand, and gravel that are eroded from farm fields, roadways, and construction sites. These materials can clog our streams, alter streamflow, and degrade the aquatic habitat. Debris, or trash, also clogs our waterways and is a threat to aquatic life (Chester Arnold and Melissa Beristain, University of Connecticut Cooperative Extension System, Hamden, Conn., Nemo project fact sheet \#2, accessed July 1, 1999, on the World Wide Web at URL http://www.lib.uconn.edu/CANR/ces/nemo, text format). 
Some elements, such as nitrogen and phosphorus, occur naturally in our environment. They are essential for the health and growth of humans, animals, and plants (Gough and others, 1993), but may be toxic if present in drinking water in concentrations greater than natural background levels. Nitrogen and phosphorus, commonly called nutrients, are added to the environment in many ways. They can be derived from commercial fertilizers, sewage-treatment plants, faulty septic systems, animal waste, atmospheric inputs from oil- and coal-burning industries, car and truck emissions, and lawn and yard maintenance (Puckett, 1995).

Nutrients cycle through the environment from soil to plants to animals and back to soil. As nitrogen moves through this cycle it is incorporated into various compounds, including nitrate, nitrite, ammonium, and organic compounds (for example, proteins). Plants and animals decompose and add organic matter to the soil. Bacteria in the soil convert the organic matter to a form that is usable by plants. People and animals eat the plants and their waste returns nitrogen to the soil. Nitrogen gas is removed from the atmosphere by certain plants through nitrogen fixation and is released as the plants decay. The decaying plants produce ammonium ions, which are converted by microorganisms in the soil to nitrate (Manahan, 1990).

High concentrations of nitrogen, in the form of nitrate or nitrite, in ground water that is used for water supply can cause methemoglobinemia ("bluebaby syndrome") in infants. Nitrate washed into streams and lakes by runoff can cause an overgrowth of algae and weeds that eventually die, depleting the water of oxygen that sustains the fish and other aquatic life. High concentrations of phosphorus contribute to excessive algal growth and is the major cause of eutrophication in lakes (Manahan, 1990).

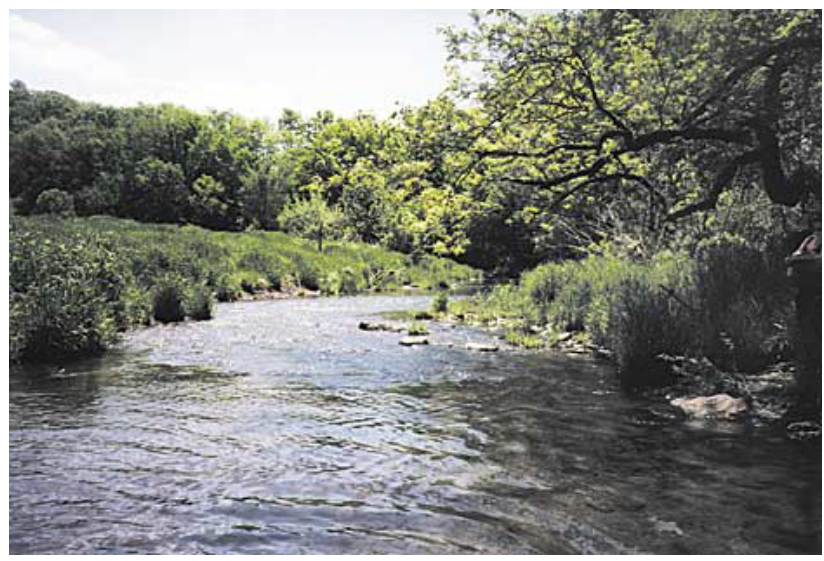

U.S. Geological Survey's surface-water-quality sampling site on the Neshanic River at Reaville, New Jersey. (Photograph by Jonathan Kennen)

\section{Surface-water quality}

Scientists who study the quality of water need to know how nitrogen and phosphorus move through the ground- and surface-water systems. Nitrogen (as nitrate), for example, is very soluble in water and, therefore, very mobile. It can easily leach into the ground water with recharge, or can be washed into nearby streams from lawns and farm fields that have been treated with fertilizer. Phosphorus (as phosphate), in contrast, is less mobile and binds to sediments.

Concentrations of nitrate and phosphate in streamflow before, during, and after a storm are shown in figure 29. The initial concentration of nitrate in the stream is diluted as a large influx of overland flow reaches the stream and the streamflow peaks. As the storm passes and runoff decreases, the nitrate concentration begins to rise again. This indicates that the nitrate in the stream is derived predominantly from ground-water discharge rather than from overland flow. 

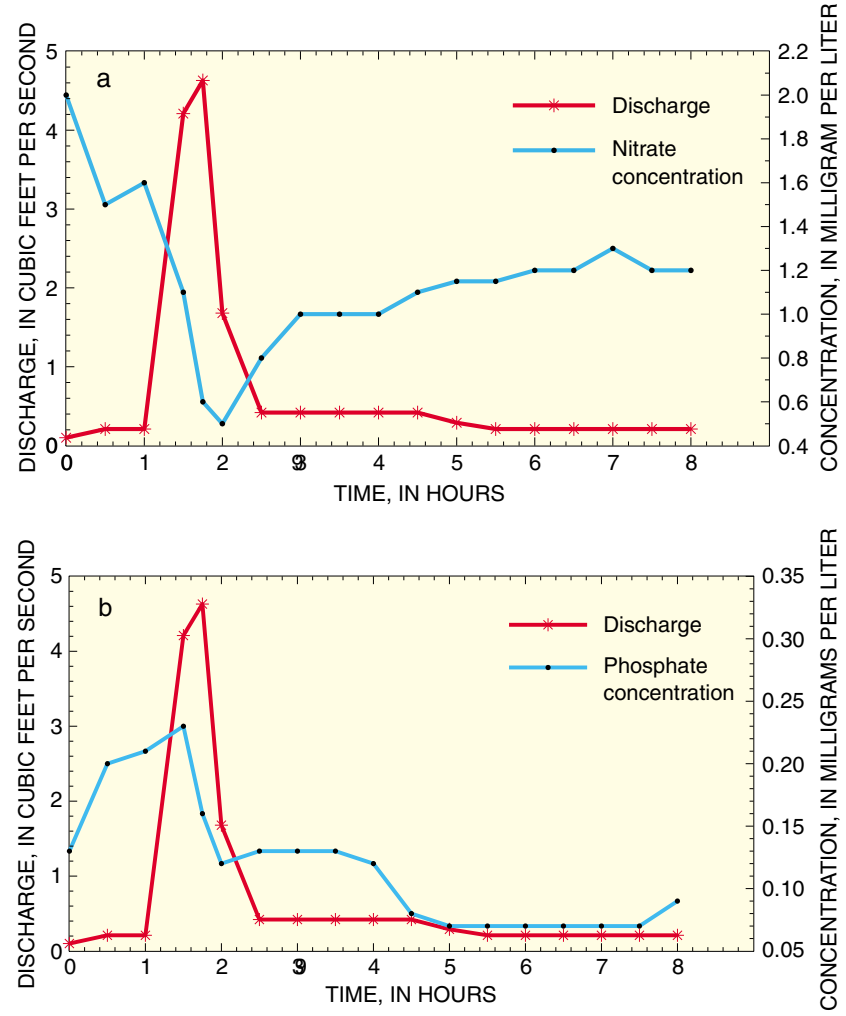

Figure 29. Concentrations of two nutrients, nitrate and phosphate, in streamflow during a typical storm. Nitrate and phosphate, because of their physical properties, act differently during storms. Nitrate dissolves easily in water, but phosphate tends to cling to sediments. (a) The concentration of nitrate in the stream is greater than $2 \mathrm{mg} / \mathrm{L}$ (milligrams per liter) before the storm begins. Most of the nitrate in the stream is derived predominantly from ground-water discharge rather than from overland flow. Therefore, as overland flow, corresponding to the peak discharge, reaches the stream, nitrate that was in the stream before the storm is diluted. As the storm passes and discharge decreases, the nitrate concentration begins to rise again. (b) Phosphates react differently. Before the storm, the phosphate concentration is about $0.13 \mathrm{mg} / \mathrm{L}$. The phosphate concentration peaks when the overland flow reaches the stream. Because the overland flow washes phosphate-containing sediments into the stream, the peaks in discharge and concentration coincide. As the discharge decreases, the phosphate concentration also decreases. (Modified from N. J. Department of Environmental Protection, 1979) 
Phosphate, in contrast, is relatively insoluble and tends to cling to sediments; therefore, phosphate concentrations in the stream between storms tend to be low. As the streamflow peaks, overland flow containing phosphate-bearing sediment reaches the stream and phosphate concentrations in the stream rise. As the storm passes and runoff decreases, the concentration of phosphate decreases to a betweenstorm minimum. This indicates that phosphate is derived mainly from the overland-runoff contribution to streamflow.

Dissolved oxygen in surface water is used by all forms of aquatic life; therefore, this constituent typically is measured to assess the "health" of lakes and streams. Oxygen enters a stream from the atmosphere and from ground-water discharge. The contribution of oxygen from ground-water discharge is significant, however, only in areas where ground water is a large component of streamflow, such as in the Coastal Plain or glacial deposits. The concentration of dissolved oxygen is inversely related to water temperature (Box E): as water temperature rises, the dissolved-oxygen concentration falls, and as water temperature falls, the dissolved-oxygen concentration rises (Reed and others, 1998). Photosynthesis is the primary process affecting the dissolved-oxygen/ temperature relation; water clarity and strength and duration of sunlight, in turn, affect the rate of photosynthesis (Reed and others, 1998). Dissolved-oxygen concentrations fluctuate with water temperature seasonally as well as diurnally (daily).

The USGS, in cooperation with the NJDEP, collects and analyzes surface-water samples throughout the State of New Jersey on a regular basis. Surface-water-quality records for New Jersey streams extend back to about 1923, and current data are now published annually in the USGS waterresources data report (Reed and others, 1998). In 1998, the surface-water-sampling network was expanded. The network was modified in order to increase the area represented and to improve data coverage by moving some of the sampling sites from year to year. Surface-water samples are collected at more than 100 sites throughout the five water regions (fig. 30). The site locations are selected to serve a variety of purposes. Some sites in each water region are selected to represent the surface water that is associated with the major land use in the water region. Others are selected to represent the quality of water downstream from large tributaries. Still others are located in pristine areas of a water region to be used as "background" or "reference" sites. Sites located on the Delaware River provide data that support the efforts of the Delaware River Basin Commission. Finally, some sites are selected randomly; these sites vary from year to year to maximize coverage of streams in each water region. These are special sites that can be located in a problem area or area of special interest to provide concentrated data coverage.

Water-column (water surface to stream bottom) samples are collected at each site four times per year during both growing and non-growing seasons. The water column constituents and properties measured depend on the site type but may include nutrients, biological oxygen demand, major ions plus boron, organic carbon, suspended sediment, field parameters $(\mathrm{pH}$, water temperature, specific conductance, dissolved-oxygen concentration, and turbidity), pesticides, trace elements, and volatile organic compounds. The stream discharge and chemical quality of stream-bottom sediments also are measured. These data can be used by planners and scientists to identify and monitor problem areas, provide background data before implementing changes to an area, and determine the effects of land use and other changes on surface-water quality. 


\section{Dissolved oxygen}

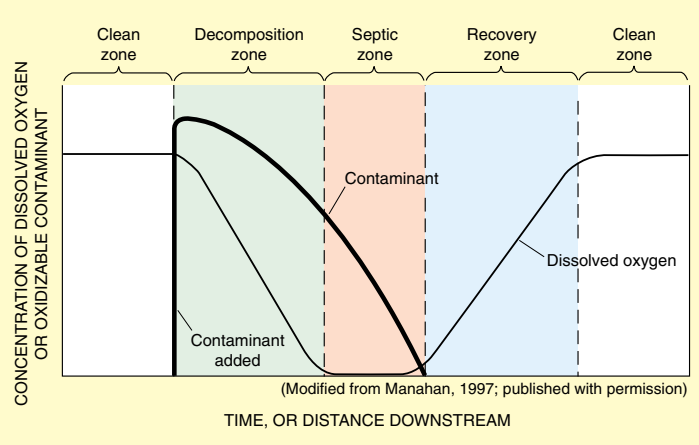

Figure E-1. Model of the oxygen-sag curve in a stream. In a healthy, uncontaminated stream, the bacteria level is low and the concentration of dissolved oxygen is high. When a contaminant is added, the dissolved oxygen begins to diminish as the bacteria decompose the contaminant. Bacteria reproduce and flourish and continue to consume dissolved oxygen. The "septic zone" is characterized by a high bacteria level and low dissolved-oxygen concentration. When the contaminant is depleted, recovery can begin. Dissolved-oxygen concentrations begin to recover and bacteria levels decrease.

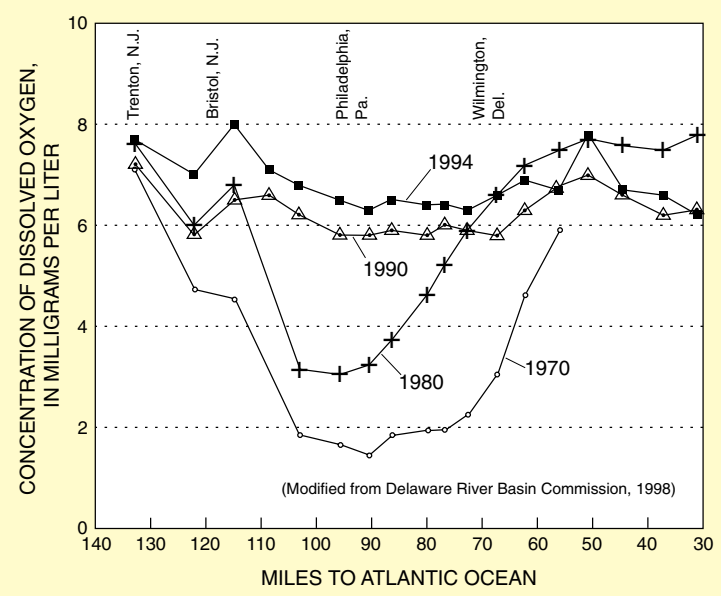

Figure E-2. Actual oxygen-sag curve for the Delaware River during 1970-94. Dissolved-oxygen concentrations measured during the 1970's and 1980's decreased between miles 115 and 90 as contaminants were discharged into the river. In recent years, as a result of cleanup efforts and the upgraded level of treatment in the wastewater-treatment plants, the dissolved-oxygen concentrations no longer drop so dramatically in this reach of the river (Richard Albert, Delaware River Basin Commission, oral commun., 1999).

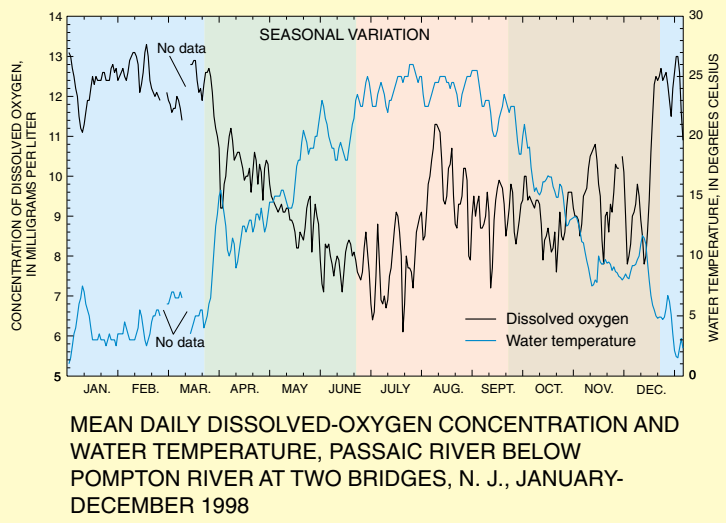

Figure E-3. The concentration of dissolved oxygen in surface water is controlled by temperature and has both a seasonal and a daily cycle. Cold water can hold more dissolved oxygen than warm water. In winter and early spring, when the water temperature is low, the dissolvedoxygen concentration is high. In summer and fall, when the water temperature is high, the dissolved-oxygen concentration is low.

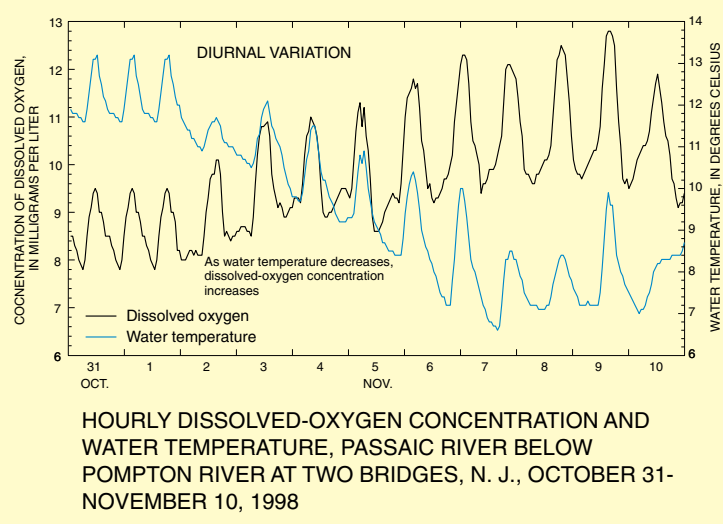

Figure E-4. Photosynthesis by algae in the stream produces oxygen and plays a large part in the dissolvedoxygen/temperature relation. Photosynthesis is affected by water clarity and the strength and duration of sunlight (Reed and others, 1998). In the diurnal (daily) cycle, during daylight hours photosynthesis produces oxygen, causing the dissolved-oxygen concentration to rise. Water temperature also rises during daylight hours. At night, the algae consume oxygen, causing the dissolvedoxygen concentration to fall. Water temperature also falls during the night. Although the effects of photosynthesis override the dissolved-oxygen/temperature relation in the diurnal cycle, the general trend of this relation can still be seen over longer periods. 


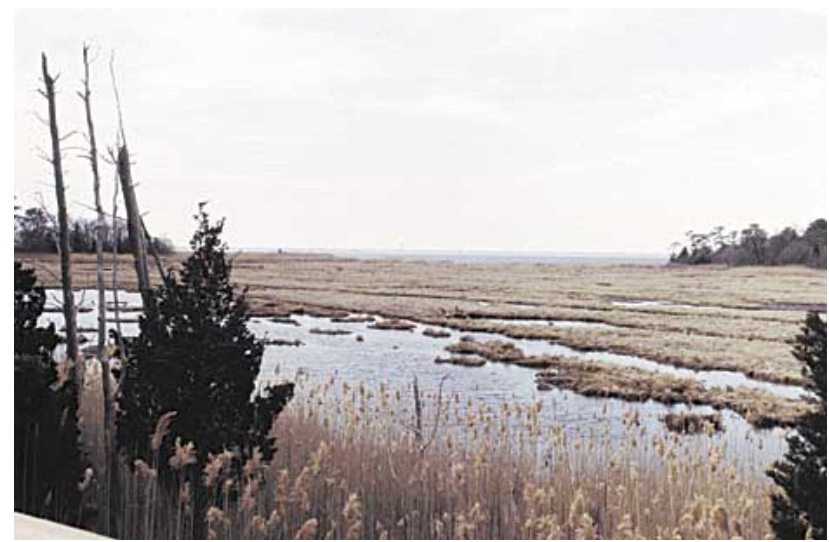

Tidal areas, Cattus Island, Ocean County, New Jersey. (Photograph by Robert Nicholson)

The NJDEP Bureau of Marine Water Monitoring analyzes water-column samples from approximately 300 sites in the tidal parts of rivers and in estuaries to monitor the ecological health of New Jersey's coastal waters (fig. 30). Constituents and properties measured at these sites include dissolved oxygen, salinity, nitrogen, phosphorus, Secchi disk depth (a turbidity measurement), temperature, suspended solids, and chlorophyll a. Samples are collected four times per year during both growing and non-growing seasons. (See N.J. Department of Environmental Protection, 1998c.) These data are used to assess the quality of water in the estuaries and tidal parts of the rivers as well as to supplement data on bacteria concentrations for determining shellfishharvesting safety.

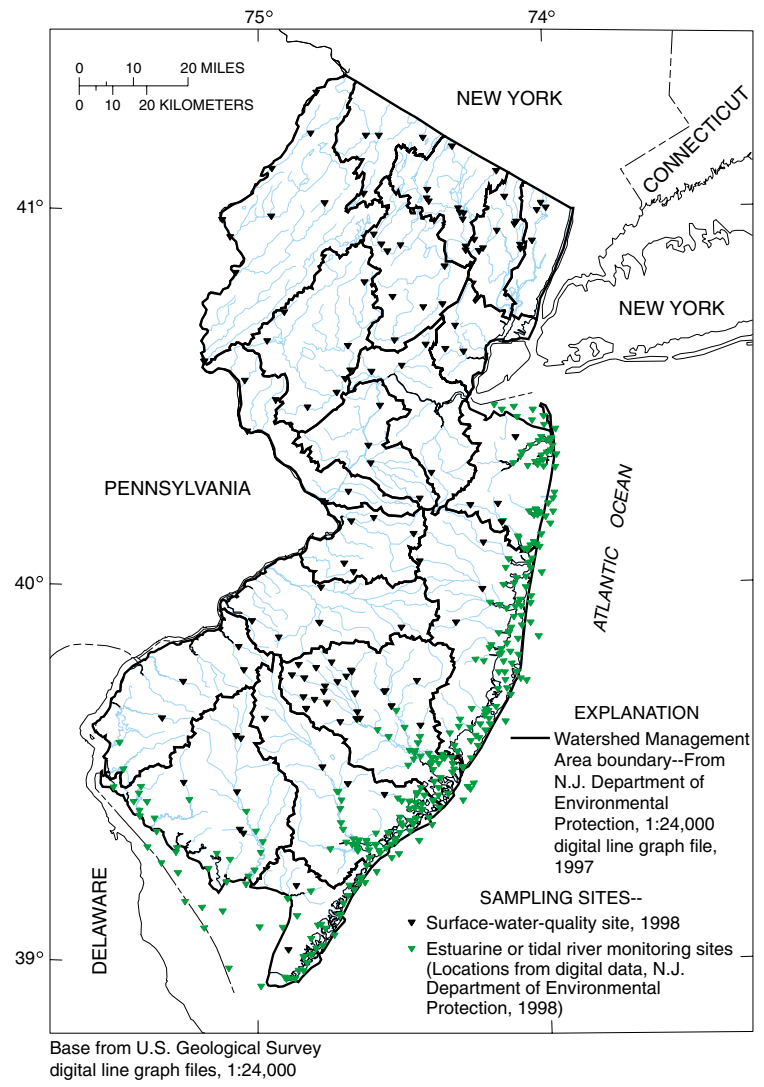

Figure 30. Surface-water-quality sampling sites and estuarine and tidal river monitoring sites active in New Jersey in 1998. Surface-water-quality data allow planners and scientists to locate problem areas, evaluate current conditions before implementing change, and calculate the effects of change. The N.J. Department of Environmental Protection analyzes water samples from the estuaries and tidal portions of rivers to monitor the ecological health of the coastal waters. 


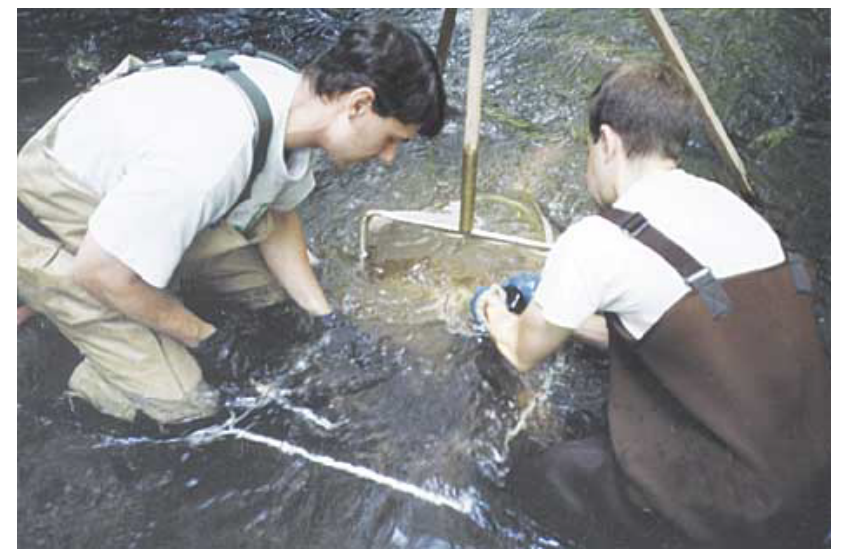

\section{Collecting macroinvertebrates in the Rockaway River at Boonton, New Jersey. (Photograph by Mark Ayers)}

\section{Biological data}

In 1992, the NJDEP Bureau of Freshwater and Biological Monitoring re-established the Ambient Biomonitoring Network (AMNET) to sample and analyze benthic (bottom-dwelling) macroinvertebrates in the non-tidal streams of New Jersey. (Previous AMNET sampling was conducted at 18 stations in 1988 (N.J. Department of Environmental Protection, 1998d).) Macroinvertebrates, animals without spinal columns, can be seen with the naked eye and live in aquatic habitats. Common freshwater benthic macroinvertebrates are aquatic insects, worms, snails, crayfish, and clams. Macroinvertebrates were collected at more than 700 sites during 1992-96 (fig. 31). These sites are located throughout the State, in each of the five water regions. Samples are collected in one water region per year on a 5-year rotational basis. Thus far, all five water regions have been monitored once. AMNET was established because the benthic macroinvertebrates found in the streams are sensitive to environmental changes and are a good indicator of the water quality. Data on benthic macroinvertebrates are compared to similar data collected at a "reference site"--a minimally disturbed site--and each is rated as either severely imparied, moderately impaired, or nonimpaired depending on the characteristics of the benthic macroinvertebrate communities that were counted at the sampling site.
Major factors that affect the benthic macroinvertebrate communities are land use upstream from the sampling site and the amount of municipal-waste effluent in the stream (Kennen, 1998). Sites in urban areas with high levels of municipal-waste effluent typically receive ratings of severely impaired. Sampling sites in forested areas or downstream from forested areas typically are judged to be nonimpaired. These ratings can help planners and officials decide where to permit discharge of wastewaters to a stream, evaluate the effects of development on the aquatic environment, and determine where remediation or additional monitoring may be necessary (Kennen, 1998; N.J. Department of Environmental Protection, 1996a).

In 1996, the NJDEP Bureau of Marine Water Monitoring began an Ambient Biomonitoring Network in the fresh- and saltwater tidal zones of New Jersey's streams and rivers. This tidal component of the AMNET sampling network is referred to as BAYNET. BAYNET sampling was initiated at 15 sites on seven major streams in the Atlantic Coastal water region (fig. 31) because of the ecological, economic, and recreational importance of these streams in New Jersey (N.J. Department of Environmental Protection, 1998a). 


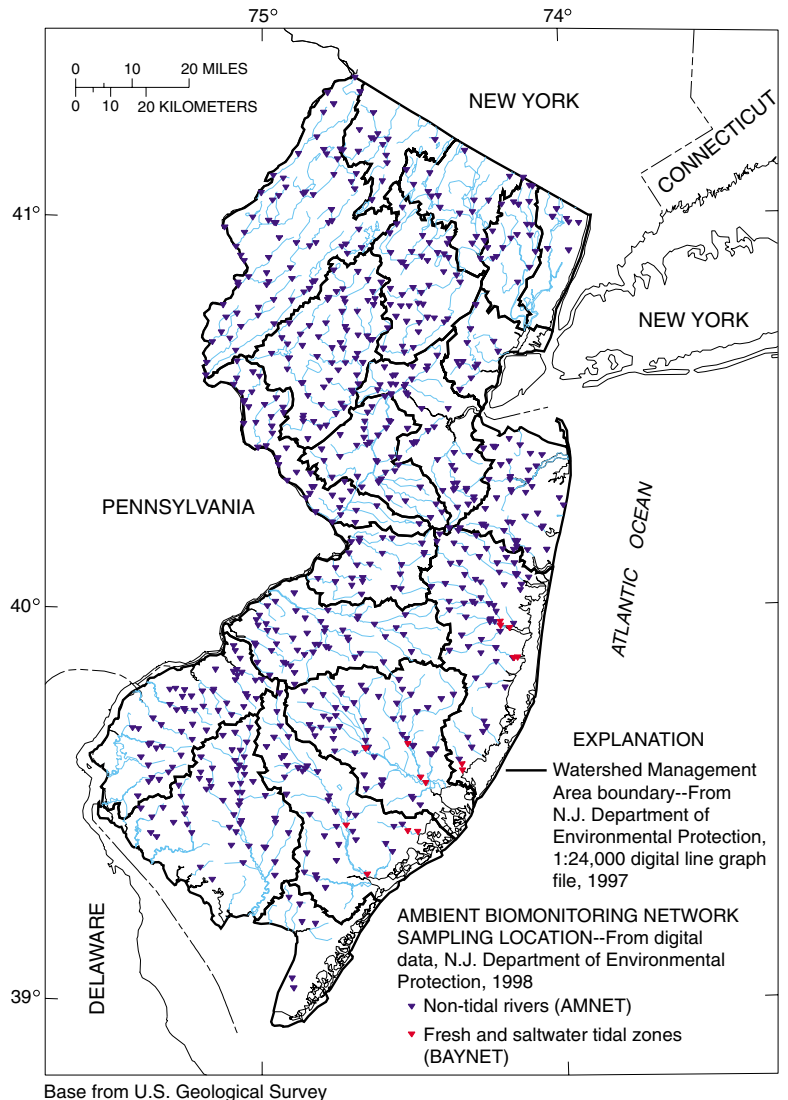

Base from U.S. Geological Survey
digital line graph files, 1:24,000

Figure 31. N.J. Department of Environmental Protection Ambient Biomonitoring Network sites in New Jersey during 1992-96. This network is operated to monitor the aquatic life in the streams and to evaluate the effects of streamwater quality on the health of aquatic communities. Data collected at these sites help planners and officials decide where to permit contaminant discharges, evaluate the effects of development on the environment, and determine where further remediation or monitoring may be needed.

\section{"...benthic macroinvertebrates found in the streams are sensitive to environmental changes and are a good indicator of the water quality."}




\section{Ground-water quality}

Because about 50 percent of all drinking water in New Jersey is derived from ground-water sources, predominantly from public-supply wells and a smaller percentage from domestic wells (U.S. Geological Survey, 1986b), ground-water quality is of great concern. Both natural and human-derived contaminants are commonly found in ground water and can include nitrates, bacteria, iron, sulfur, methane gas, radium, pesticides, and petroleum and other organic compounds (Waller, 1994). Naturally occurring contaminants are present in the rocks and sediments. As ground water flows through sediments, metals such as iron and manganese are dissolved and may later be found in high concentrations in the water. Industrial discharges, urban activities, agriculture, ground-water pumpage, and disposal of waste all can affect ground-water quality. Contaminants from leaking fuel tanks or fuel or toxic chemical spills may enter the ground water and contaminate the aquifer. Pesticides and fertilizers applied to lawns and crops can accumulate and migrate to the water table. Bacterial contamination from septictank effluent is one of the most common water-quality problems in rural areas (Waller, 1994).

The physical properties of an aquifer, such as thickness, rock or sediment type, and location, play a large part in determining whether contaminants from the land surface will reach the ground water. The risk of contamination is greater for unconfined (water-table) aquifers than for confined aquifers because they usually are nearer to land surface and lack an overlying confining layer to impede the movement of contaminants. Because ground water moves slowly in the subsurface and many contaminants sorb to the sediments, restoration of a contaminated aquifer is difficult and may require years, decades, centuries, or even millennia.

Some of the contaminants commonly detected in drinking-water supplies derived from ground water in New Jersey and their potential health effects are listed in table 6. Inorganic and organic chemicals, microbiological and radiological contaminants, and physical characteristics of ground water are listed.

The USGS, in cooperation with the NJDEP, has been collecting and analyzing ground-water

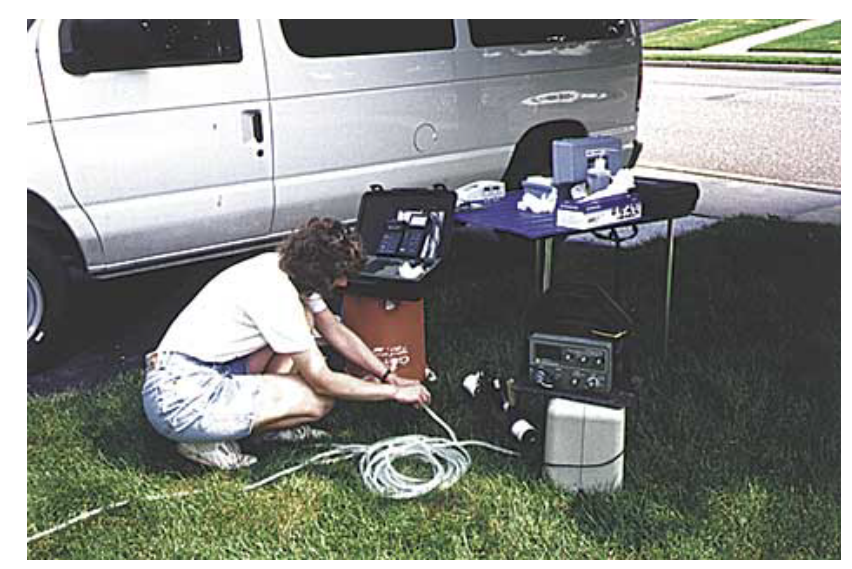

Sampling ground water from a domestic well. (Photograph by Rick Clawges)

samples since the late 1800 's, and a formal monitoring program to investigate saltwater intrusion began in 1923 (U.S. Geological Survey, 1986b). In the early 1960's, the USGS began sampling approximately 20 wells per year, mostly in the Coastal Plain, to measure concentrations of inorganic ions and compounds. In the early 1980's, an ambient groundwater-quality network was established to monitor water quality in all aquifers throughout the State. The few constituents for which samples were analyzed included various organic compounds and trace elements. Current (2000) plans for the ambient ground-water-quality network are to increase the number of wells sampled per year in all five water regions. The focus of the network will be to sample water in shallow wells that are completed in the unconfined aquifer to improve understanding of the ground-water/surface-water interaction. Samples will be analyzed for concentrations of nutrients, major ions, trace elements, volatile organic compounds, and radionuclides.

The USGS also conducts studies on a regional, county, township, and site-specific basis to investigate ground-water-quality problems. In the 1970's, a typical water-quality analysis included measuring concentrations of chloride, sulfate, major ions, and some trace elements, mostly for regional and countywide studies. During the 1980's, laboratory instrumentation became more precise, analytical detection levels were lowered, sampling methods improved, and the knowledge of which constituents were likely to be present in the ground water increased. Samples 
Table 6. Contaminants commonly detected in drinking water derived from ground-water sources

Contaminant

Sources to ground water

Aluminum

Antimony

Arsenic

Asbestos

Barium

Beryllium

Cadmium

Chloride

Chromium

Copper

Cyanide

Dissolved solids

Fluoride

Hardness

Iron

Lead

Manganese

Occurs naturally in some rocks and drainage from mines. explosives. trial waste, smelting of copper, lead, and zinc ore. plastic stabilizers, and landfill leachate. domestic waste. eral leaching. production; also from improper waste disposal. ating or abandoned mines. and corroding metal. additive.
Inorganic contaminants

Can precipitate out of water after treatment, causing increased turbidity or discolored water.

Enters environment from natural weathering, industrial production, municipal waste dis- Decreases longevity, alters blood levels of glucose and cholesterol in laboratory animals posal, and manufacturing of flame retardants, ceramics, glass, batteries, fireworks, and

Enters environment from natural processes, industrial activities, pesticides, and indus-

Occurs naturally; also from corroded asbestos cemented pipes, production of textiles, plastics, cements, flood tiles, paper products, paint, caulking, and fire-retardant material.

Occurs naturally in some limestones, sandstones, and soils in the eastern United States.

Occurs naturally in soils, ground water, and surface water. Often used in electrical industry equipment and components, nuclear power and space industry. Enters the environment from mining operations, processing plants, and improper waste disposal.

Found in low concentrations in rocks, coal, and petroleum and enters the ground and surface water when dissolved by acidic waters. May enter the environment from industrial discharge, mining waste, metal plating, water pipes, batteries, paints and pigments,

May be associated with the presence of sodium in drinking water when present in high concentrations. Often from saltwater intrusion, mineral dissolution, industrial and

Enters environment from old mining operations runoff and leaching into ground water, fossil-fuel combustion, cement-plant emissions, mineral leaching, and waste incineration. Used in metal plating and as a cooling-tower water additive.

Often used in electroplating, steel processing, plastics, synthetic fabrics, and fertilizer

Occur naturally but also enters environment from man-made souces such as lanthe leachate, feedlots, or sewage. A measure of the dissolved "salts" or minerals in the water. May also include some dissolved organic compounds.

exposed at high levels over their lifetime.

Causes acute and chronic toxicity, liver and kidney damage; decreases blood hemoglobin. Possible carcinogen.

Causes lung tumors in laboratory animals during inhalation studies.

Can cause a variety of cardiac, gastrointestinal, and neuromuscular effects. Associated with hypertension and cardiotoxicity in animals.

Causes acute and chronic toxicity; can cause damage to lungs and bones. Possible carcinogen.

Replaces zinc biochemically in the body and causes high blood pressure, liver and kidney damage, and anemia. Destroys testicular tissue and red blood cells. Toxic to aquatic biota.

Deteriorates plumbing, water heaters, and municipal water-works equipment at high levels. Above secondary maximum contaminant level, taste becomes noticeable.

Chromium III is a nutritionally essential element. Chromium VI is much more toxic than Chromium III and causes liver and kidney damage, internal hemorrhaging, respiratory damage, dermatitis, and ulcers on the skin at high concentrations.

Can cause stomach and intestinal distress, liver and kidney damage, anemia in high doses. Imparts an adverse taste and significant staining to clothes and fixtures. Essential trace element but toxic to plants and algae at moderate levels.

Poisoning is the result of damage to spleen, brain, and liver.

May have an influence on the acceptability of water in general. May be indicative of the presence of excess concentrations of specific substances not included in the Safe Water Drinking Act, which would make water objectionable. High concentrations of dissolved solids shorten the life of hot water heaters.

Decreases incidence of tooth decay but high levels can stain or mottle teeth. Causes crippling bone disorder (calcification of the bones and joints) at very high levels.

Decreases the lather formation of soap and increases scale formation in hot-water heaters and low-pressure boilers at high levels.

Result of metallic ions dissolved in the water; reported as concentration of calcium carbonate. Calcium carbonate is derived from dissolved limestone or discharges from oper-

Occurs naturally as a mineral from sediment and rocks or from mining, industrial waste,

Enters environment from industry, mining, plumbing, gasoline, coal, and as a water

plumbing bitter astrin

plumbing fixtures.

Affects red blood cell chemistry; delays normal physical and mental development in babies and young children. Causes slight deficits in attention span, hearing, and learning ogen.

Occurs naturally as a mineral from sediment and rocks or from mining and industrial waste.

Causes aesthetic and economic damage, and imparts brownish stains to laundry. Affects taste of water, and causes dark brown or black stains on plumbing fixtures. Relatively non-toxic to animals but toxic to plants at high levels. 
Table 6. Contaminants commonly detected in drinking water derived from ground-water sources--Continued

\begin{tabular}{|c|c|c|}
\hline Contaminant & Sources to ground water & Potential health and other effects \\
\hline Mercury & $\begin{array}{l}\text { Occurs as an inorganic salt and as organic mercury compounds. Enters the environment } \\
\text { from industrial waste, mining, pesticides, coal, electrical equipment (batteries, lamps, } \\
\text { switches), smelting, and fossil-fuel combustion. }\end{array}$ & $\begin{array}{l}\text { Causes acute and chronic toxicity. Targets the kidneys and can cause nervous system } \\
\text { disorders. }\end{array}$ \\
\hline Nickel & $\begin{array}{l}\text { Occurs naturally in soils, ground water, and surface water. Often used in electroplating, } \\
\text { stainless steel and alloy products, mining, and refining. }\end{array}$ & $\begin{array}{l}\text { Damages the heart and liver of laboratory animals exposed to large amounts over their } \\
\text { lifetime. }\end{array}$ \\
\hline $\begin{array}{l}\text { Nitrate } \\
\text { (as nitrogen) }\end{array}$ & $\begin{array}{l}\text { Occurs naturally in mineral deposits, soils, seawater, freshwater systems, the atmo- } \\
\text { sphere, and biota. More stable form of combined nitrogen in oxygenated water. Found in } \\
\text { the highest levels in ground water under extensively developed areas. Enters the envi- } \\
\text { ronment from fertilizer, feedlots, and sewage. }\end{array}$ & $\begin{array}{l}\text { Toxicity results from the body's natural breakdown of nitrate to nitrite. Causes "blue- } \\
\text { baby disease," or methemoglobinemia, which threatens oxygen-carrying capacity of the } \\
\text { blood. }\end{array}$ \\
\hline $\begin{array}{l}\text { Nitrite } \\
\text { (combined } \\
\text { nitrate/ } \\
\text { nitrite) }\end{array}$ & Enters environment from fertilizer, sewage, and human or farm-animal waste. & $\begin{array}{l}\text { Toxicity results from the body's natural breakdown of nitrate to nitrite. Causes "blue- } \\
\text { baby disease," or methemoglobinemia, which threatens oxygen-carrying capacity of the } \\
\text { blood. }\end{array}$ \\
\hline Selenium & Enters environment from naturally occurring geologic sources, sulfur, and coal. & $\begin{array}{l}\text { Causes acute and chronic toxic effects in animals--"blind staggers" in cattle. Nutrition- } \\
\text { ally essential element at low doses but toxic at high doses. }\end{array}$ \\
\hline Silver & $\begin{array}{l}\text { Enters environment from ore mining and processing, product fabrication, and disposal. } \\
\text { Often used in photography, electric and electronic equipment, sterling and electroplat- } \\
\text { ing, alloy, and solder. Because of great economic value of silver, recovery practices are } \\
\text { typically used to minimize loss. }\end{array}$ & $\begin{array}{l}\text { Can cause argyria, a blue-gray coloration of the skin, mucous membranes, eyes, and } \\
\text { organs in humans and animals with chronic exposure. }\end{array}$ \\
\hline Sodium & $\begin{array}{l}\text { Derived geologically from leaching of surface and underground deposits of salt and } \\
\text { decomposition of various minerals. Human activities contribute through de-icing and } \\
\text { washing products. }\end{array}$ & Can be a health risk factor for those individuals on a low-sodium diet. \\
\hline Sulfate & $\begin{array}{l}\text { Elevated concentrations may result from saltwater intrusion, mineral dissolution, and } \\
\text { domestic or industrial waste. }\end{array}$ & $\begin{array}{l}\text { Forms hard scales on boilers and heat exchangers; can change the taste of water, and has } \\
\text { a laxative effect in high doses. }\end{array}$ \\
\hline Thallium & $\begin{array}{l}\text { Enters environment from soils; used in electronics, pharmaceuticals manufacturing, } \\
\text { glass, and alloys. }\end{array}$ & $\begin{array}{l}\text { Damages kidneys, liver, brain, and intestines in laboratory animals when given in high } \\
\text { doses over their lifetime. }\end{array}$ \\
\hline Zinc & $\begin{array}{l}\text { Found naturally in water, most frequently in areas where it is mined. Enters environment } \\
\text { from industrial waste, metal plating, and plumbing, and is a major component of sludge. }\end{array}$ & $\begin{array}{l}\text { Aids in the healing of wounds. Causes no ill health effects except in very high doses. } \\
\text { Imparts an undesirable taste to water. Toxic to plants at high levels. }\end{array}$ \\
\hline \multicolumn{3}{|c|}{ Organic contaminants } \\
\hline $\begin{array}{l}\text { Volatile } \\
\text { organic } \\
\text { compounds }\end{array}$ & $\begin{array}{l}\text { Enter environment when used to make plastics, dyes, rubbers, polishes, solvents, crude } \\
\text { oil, insecticides, inks, varnishes, paints, disinfectants, gasoline products, pharmaceuti- } \\
\text { cals, preservatives, spot removers, paint removers, degreasers, and many more. }\end{array}$ & $\begin{array}{l}\text { Can cause cancer and liver damage, anemia, gastrointestinal disorder, skin irritation, } \\
\text { blurred vision, exhaustion, weight loss, damage to the nervous system, and respiratory } \\
\text { tract irritation. }\end{array}$ \\
\hline Pesticides & Enter environment as herbicides, insecticides, fungicides, rodenticides, and algicides. & $\begin{array}{l}\text { Cause poisoning, headaches, dizziness, gastrointestinal disturbance, numbness, weak- } \\
\text { ness, and cancer. Destroys nervous system, thyroid, reproductive system, liver, and kid- } \\
\text { neys. }\end{array}$ \\
\hline $\begin{array}{l}\text { Plasticizers, } \\
\text { chlorinated } \\
\text { solvents, } \\
\text { benzo[a]py- } \\
\text { rene, and } \\
\text { dioxin }\end{array}$ & $\begin{array}{l}\text { Used as sealants, linings, solvents, pesticides, plasticizers, components of gasoline, dis- } \\
\text { infectant, and wood preservative. Enters the environment from improper waste disposal, } \\
\text { leaching runoff, leaking storage tank, and industrial runoff. }\end{array}$ & Cause cancer. Damages nervous and reproductive systems, kidney, stomach, and liver. \\
\hline $\begin{array}{l}\text { Foaming } \\
\text { agents } \\
(\text { ABS/LAS })^{1}\end{array}$ & $\begin{array}{l}\text { Indicative of undesirable contaminants from questionable sources like infiltration from } \\
\text { sewage. }\end{array}$ & Impart undesirable taste and foaming properties. \\
\hline
\end{tabular}

${ }^{1}$ Alkyl-Benzene-Sulfonate and Linear-Alkyl-sulfonate or similar Methylene Blue Reactive Substances contained in synthetic detergents. 
Table 6. Contaminants commonly detected in drinking water derived from ground-water sources--Continued

$\begin{array}{llc}\text { Contaminant } & \text { Sources to ground water } & \text { Potential health and other effects }\end{array}$

\begin{tabular}{|c|c|c|}
\hline Contaminant & Sources to ground water & Potential health and other effects \\
\hline \multicolumn{3}{|c|}{$\underline{\text { Microbiological contaminants }}$} \\
\hline $\begin{array}{l}\text { Coliform } \\
\text { bacteria }\end{array}$ & $\begin{array}{l}\text { Occur naturally in the environment from soils and plants and in the intestines of humans } \\
\text { and other warm-blooded animals. Used as an indicator for the presence of pathogenic } \\
\text { bacteria, viruses, and parasites from domestic sewage, animal waste, or plant or soil } \\
\text { material. }\end{array}$ & $\begin{array}{l}\text { Bacteria, viruses, and parasites can cause polio, cholera, typhoid fever, dysentery, and } \\
\text { infectious hepatitis. }\end{array}$ \\
\hline \multicolumn{3}{|c|}{ Radiological contaminants } \\
\hline $\begin{array}{l}\text { Gross alpha-parti- } \\
\text { cle activity }\end{array}$ & $\begin{array}{l}\text { A category of radioactive isotopes. Occurs from either natural or man-made sources } \\
\text { including weapons, nuclear reactors, atomic energy for power, medical treatment and } \\
\text { diagnosis, mining radioactive material, and naturally occurring radioactive geologic for- } \\
\text { mations. Primary concern is natural sources, which are ubiquitous in the environment } \\
\text { (Durrance, 1986); secondary concern is man-made sources. }\end{array}$ & Damages tissues and destroys bone marrow. \\
\hline $\begin{array}{l}\text { Combined } \\
\text { radium- } 226 \text { and } \\
\text { radium-228 }\end{array}$ & $\begin{array}{l}\text { Enters environment from natural and man-made sources. Historical industrial-waste } \\
\text { sites are the main man-made source. }\end{array}$ & Causes cancer by concentrating in the bone and skeletal tissue. \\
\hline $\begin{array}{l}\text { Beta-particle } \\
\text { and photon } \\
\text { radioactivity }\end{array}$ & $\begin{array}{l}\text { A category of radioactive isotopes from either natural or man-made sources including } \\
\text { weapons, nuclear reactors, atomic energy for power, medical treatment and diagnosis, } \\
\text { mining radioactive material, and naturally occurring radioactive geologic formations. } \\
\text { Primary concern is man-made sources because of widespread use (Durrance, 1986); sec- } \\
\text { ondary concern is natural sources. }\end{array}$ & Damages tissues and destroys bone marrow. \\
\hline \multicolumn{3}{|c|}{ Physical characteristics } \\
\hline Turbidity & $\begin{array}{l}\text { Caused by the presence of suspended matter such as clay, silt, and fine particles of } \\
\text { organic and inorganic matter, plankton, and other microscopic organisms. A measure of } \\
\text { how much light can filter through the water sample. }\end{array}$ & $\begin{array}{l}\text { Objectionable for aesthetic reasons. Indicative of clay or other inert suspended particles } \\
\text { in drinking water. May not adversely affect health but may cause need for additional } \\
\text { treatment. Following rainfall, variations in ground-water turbidity may be an indicator } \\
\text { of surface contamination. }\end{array}$ \\
\hline Color & $\begin{array}{l}\text { Can be caused by decaying leaves, plants, organic matter, copper, iron, and manganese, } \\
\text { which may be objectionable. Indicative of large amounts of organic chemicals, inade- } \\
\text { quate treatment, and high disinfection demand. Potential for production of excess } \\
\text { amounts of disinfection byproducts. }\end{array}$ & Suggests that treatment is needed. No health concerns. Aesthetically unpleasing. \\
\hline $\mathrm{pH}$ & $\begin{array}{l}\text { Indicates, by numerical expression, the degree to which water is alkaline or acidic. Rep- } \\
\text { resented on a scale of } 0-14 \text { where } 0 \text { is the most acidic, } 14 \text { is the most alkaline, and } 7 \text { is } \\
\text { neutral. }\end{array}$ & $\begin{array}{l}\text { High pH causes a bitter taste; water pipes and water-using appliances become encrusted; } \\
\text { depresses the effectiveness of the disinfection of chlorine, thereby causing the need for } \\
\text { additional chlorine when pH is high. Low-pH water will corrode or dissolve metals and } \\
\text { other substances. }\end{array}$ \\
\hline Odor & $\begin{array}{l}\text { Certain odors may be indicative of organic or non-organic contaminants that originate } \\
\text { from municipal or industrial waste discharges or from natural sources. }\end{array}$ & \\
\hline Taste & $\begin{array}{l}\text { Some substances such as certain organic salts produce a taste without an odor and can be } \\
\text { evaluated by a taste test. Many other sensations ascribed to the sense of taste actually are } \\
\text { odors, even though the sensation is not noticed until the material is taken into the mouth. }\end{array}$ & \\
\hline
\end{tabular}




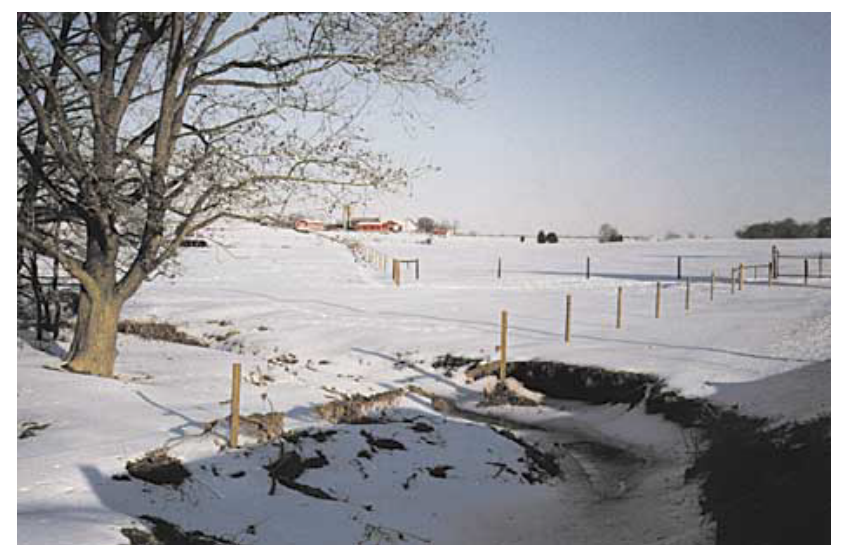

\section{Rural Salem County, New Jersey. (Photograph by Melissa Storck)}

commonly were analyzed for volatile organic compounds, radionuclides, and pesticides as well as other organic compounds, inorganic compounds, and trace elements. Water-quality data for more than 2,000 wells in New Jersey are available in the USGS data base (fig. 32). Because the number of analytes (constituents measured in a water sample) has increased with time, more water-quality data generally are available for recently collected samples than for samples collected several years or decades ago.

Nitrate concentrations in samples from more than 2,000 wells throughout the State are shown in figure 33. Nitrate commonly occurs in ground water in concentrations greater than the USEPA MCL of $10 \mathrm{mg} / \mathrm{L}$ (milligrams per liter) as a result of human activities. Nitrate is very mobile and dissolves easily in water. Sources include fertilizers, septic systems, and animal waste. Wells that contain high concentrations of nitrate are found predominantly in agricultural and urban areas. Shallow wells are more vulnerable to nitrate contamination than are deeper wells. Parts of New Jersey in which nitrate concentrations in ground water are elevated include Cumberland and Salem Counties, where agriculture is the dominant land use. Nitrate concentrations also are elevated along the Delaware River near Camden and where many of the Coastal Plain aquifers crop out at the land surface. Ground water in older residential areas also tends to contain elevated nitrate concentrations. Nitrate concentrations tend to be low in undeveloped and nonagricultural areas and in wells that are completed in confined aquifers. Dilution of young, nitrate-contaminated ground water with older, uncontaminated ground water also can account for low nitrate concentrations. This situation typically occurs in northern New Jersey, where wells are drilled in consolidated rock and commonly are open holes that may extend for hundreds of feet, allowing the younger and older ground water to mix.

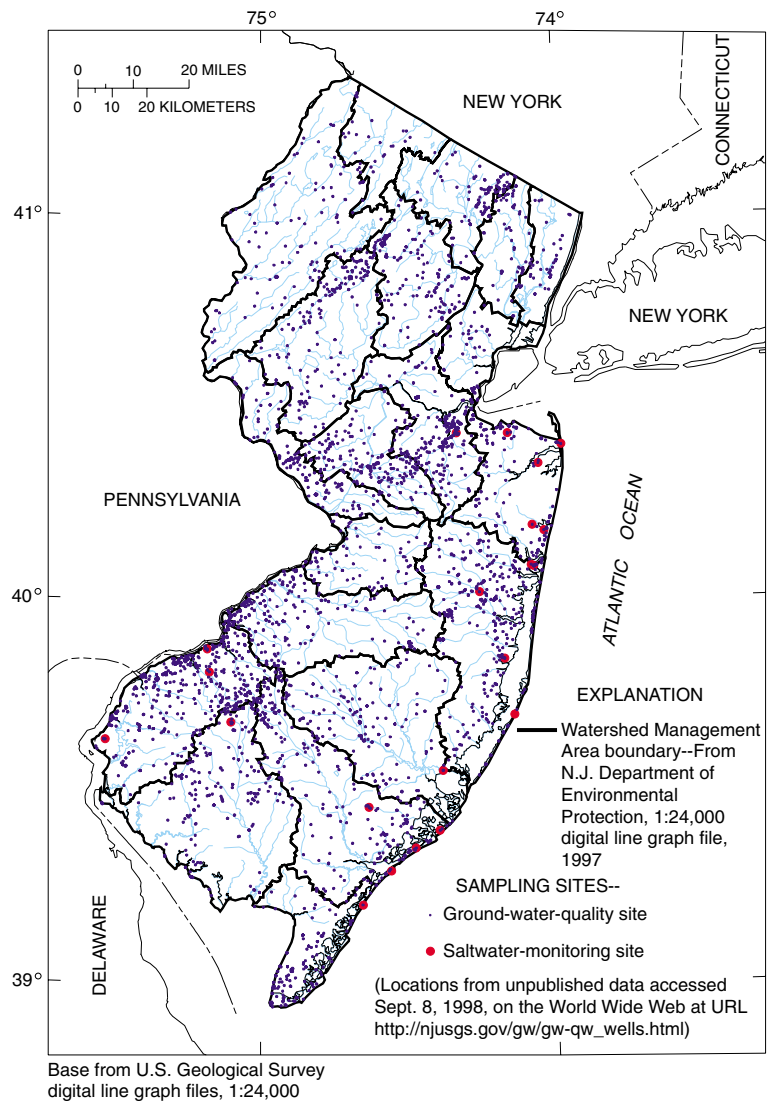

Figure 32. Ground-water-quality and saltwatermonitoring sites in New Jersey. The ground-waterquality sites represent all wells for which water-quality data are stored in the U.S. Geological Survey data base. Samples from newer wells typically were analyzed for a greater number of constituents than samples from older wells. The saltwater-monitoring network was established in the 1940's to monitor the movement of saline water, which can affect the potability of the ground-water supply. 


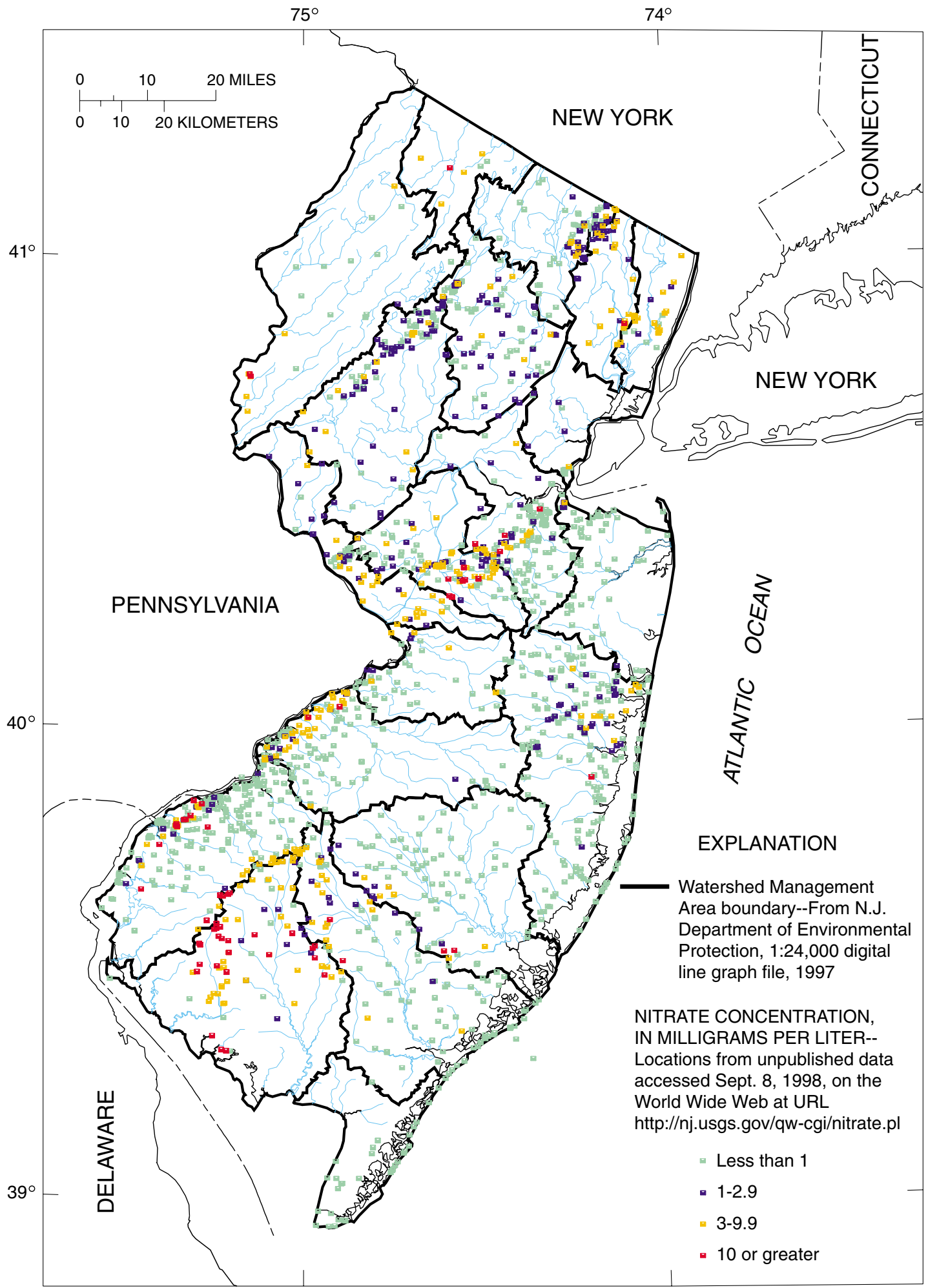

Base from U.S. Geological Survey

digital line graph files, 1:24,000

Figure 33. Nitrate concentrations in water from wells in New Jersey. Nitrate in ground water is a potential problem because it is easily dissolved, is very mobile at certain concentrations, and can be dangerous to the health of infants. High nitrate concentrations are typically associated with agriculture and urban development. The risk of nitrate contamination is greater for unconfined aquifers than for confined aquifers because they are not protected by a confining unit from contaminants originating at land surface. 


\section{Saltwater monitoring}

Chloride concentrations affect the potability (suitability as drinking water) of water and also serve as an accurate index of saltwater intrusion. Saltwater intrusion is the movement of saltwater into an aquifer that contains freshwater. The freshwater that recharges the aquifer is continually discharging to the ocean. It may discharge to the ocean directly as ground water or may flow into a stream that ultimately flows to the ocean. Freshwater continually mixes with the saltwater in the ocean. The point at which they meet is called the freshwater/saltwater interface (fig. 3). If for some reason the amount of freshwater that usually discharges to the ocean is reduced--by ground-water withdrawals, for example--the interface moves landward. This phenomenon has been observed in many parts of the New Jersey Coastal Plain.

The USGS collects water samples from wells located throughout the Coastal Plain of New Jersey and in the Lower Delaware and Raritan water regions to measure chloride concentrations (fig. 32). This network was established in the 1940's to monitor saltwater movement. Individual occurrences of high chloride concentrations are not definitive proof of active saltwater intrusion, however; they may represent a natural, static condition (Jones and DeLuca, 1998). Therefore, increasing chloride concentrations over time, rather than single measurements, must be documented in order to confirm that saltwater intrusion is occurring.

The change in chloride concentrations over time in wells in the Atlantic Coastal water region, as well as historical withdrawals from those wells, are shown in figure 34 . As coastal resort areas were developed, the need for freshwater increased. Consequently, withdrawals increased until chloride concentrations reached $250 \mathrm{mg} / \mathrm{L}$, the USEPA secondary maximum contaminant level for chloride (U.S. Environmental Protection Agency, 1990). Although withdrawals subsequently were decreased, chloride concentrations continued to climb (unpublished data on file at the U.S. Geological Survey office in West Trenton, N.J.). Possible solutions to this problem include drilling new wells in parts of the aquifer that contain lower chloride concentrations, building a plant that removes the chloride from the water (desalinization), or reducing withdrawals and importing freshwater from neighboring areas.

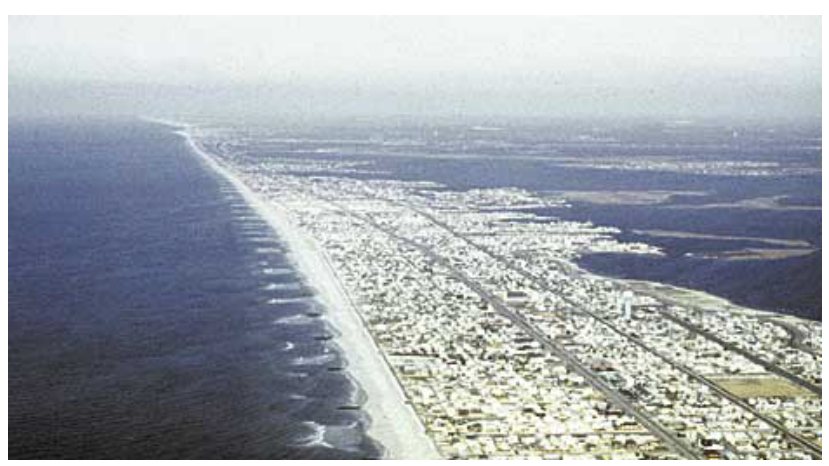

Development along the New Jersey coast, Seaside Heights. (File photograph, U.S. Geological Survey, West Trenton, New Jersey) 


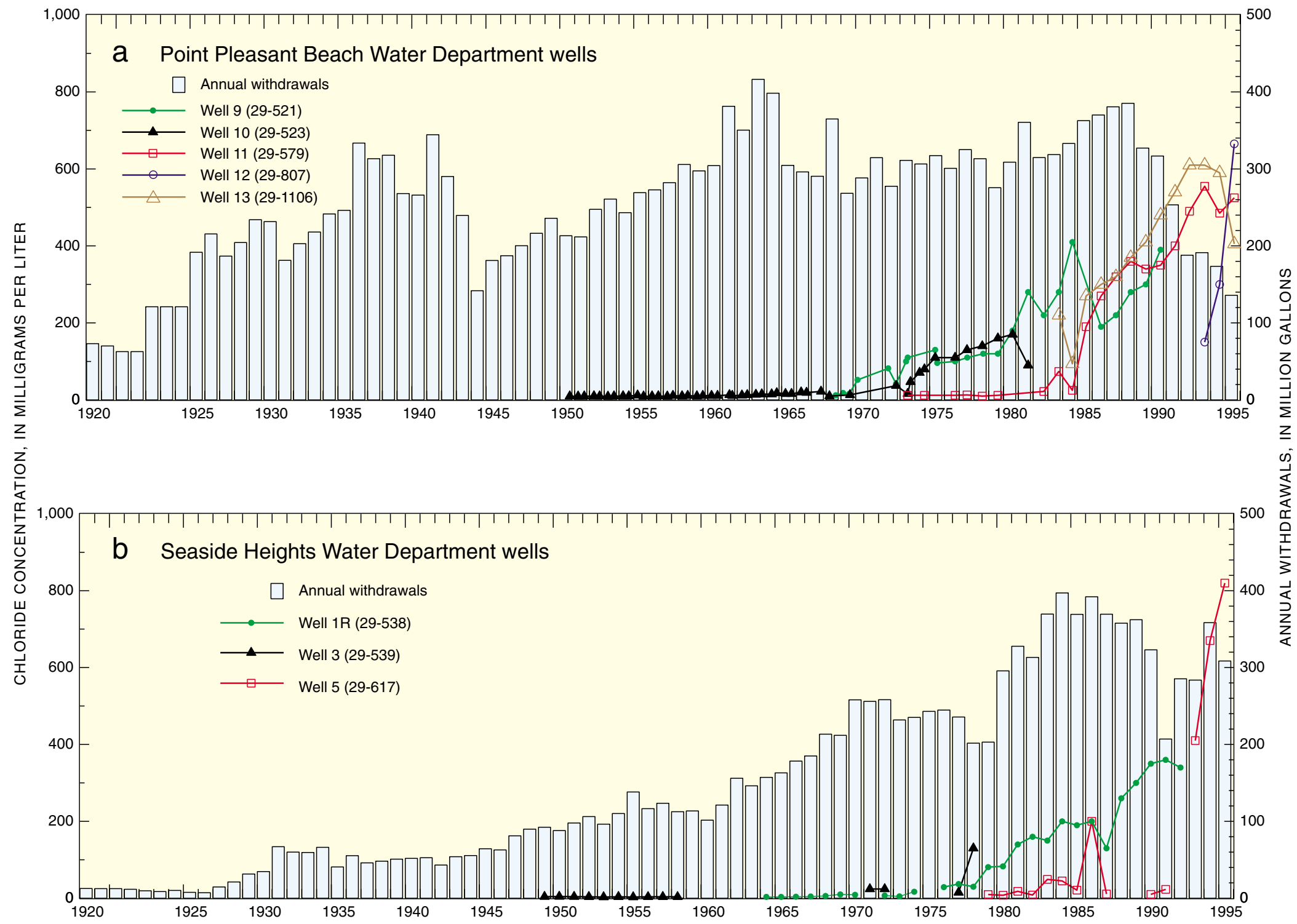

Figure 34. Annual withdrawals from the Kirkwood-Cohansey aquifer system and late summer chloride concentrations in water from selected wells at (a) Point Pleasant Beach and (b) Seaside Heights, New Jersey, 1918-95. Chloride concentrations increased with ground-water withdrawals, indicating saltwater intrusion. In some years, chloride concentrations continued to climb despite decreased withdrawals. (Unpublished data on file at the U.S. Geological Survey office in West Trenton, N.J.; numbers in parentheses are U.S. Geological Survey well numbers) 


\section{Potential Contaminant Sources}

\section{New Jersey Pollutant Discharge Elimination System (NJPDES) Sites}

The NJDEP's New Jersey Pollutant Discharge Elimination System (NJPDES) program, started in 1981, monitors and regulates the amount of waste and contaminants that is discharged to surface and ground water. Permits are granted for industrial, commercial, and municipal water users that discharge to surface- or ground-water sources. Groundwater discharges are divided into two major programs: remedial discharges and operational discharges. Remedial discharges include the reinjection of ground water that has been treated in cleanup programs. Operational discharges include effluent from major septic systems, land applications that include surface impoundments and infiltration/percolation lagoons, injection wells, resource-recovery uses of sludge and compost, and landfills for both hazardous and nonhazardous material (N.J. Department of
Environmental Protection, 1996b). Locations of the NJPDES permitted discharges in the State are shown in figure 35. NJPDES sites are divided into major, minor, non-contact cooling, and petroleum-cleanup sites. Major industrial sites are defined as sites that score 80 or more points on a USEPA guideline point system that measures characteristics of industrial facilities; minor sites score less than 80 points. A major municipal facility is defined as a site with flow of 1.0 Mgal/d (million gallons per day) or greater; a minor municipal facility is a site where flow is less than $1.0 \mathrm{Mgal} / \mathrm{d}$. Non-contact cooling sites typically use water for heat exchange. Petroleum-cleanup sites are generally located at gas or service stations. (See N.J. Department of Environmental Protection, 1997b.) Discharge sites are concentrated in the more developed parts of the State. All permittees are required to perform routine water-quality monitoring. These data, together with the permitting process, provide the information and control necessary to protect the quality of water in a watershed by identifying point sources of contaminants and controlling the amount that can be discharged.

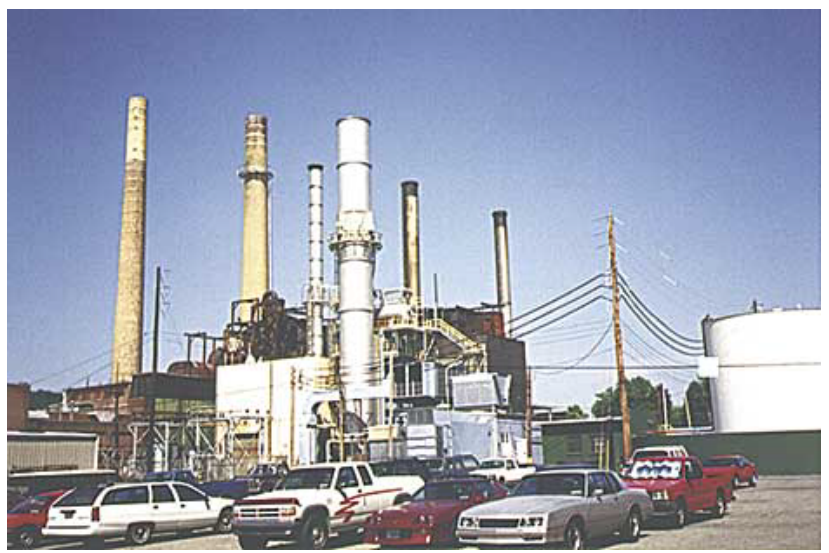

Industrial site, New Jersey. (Photograph by Rick Clawges) 


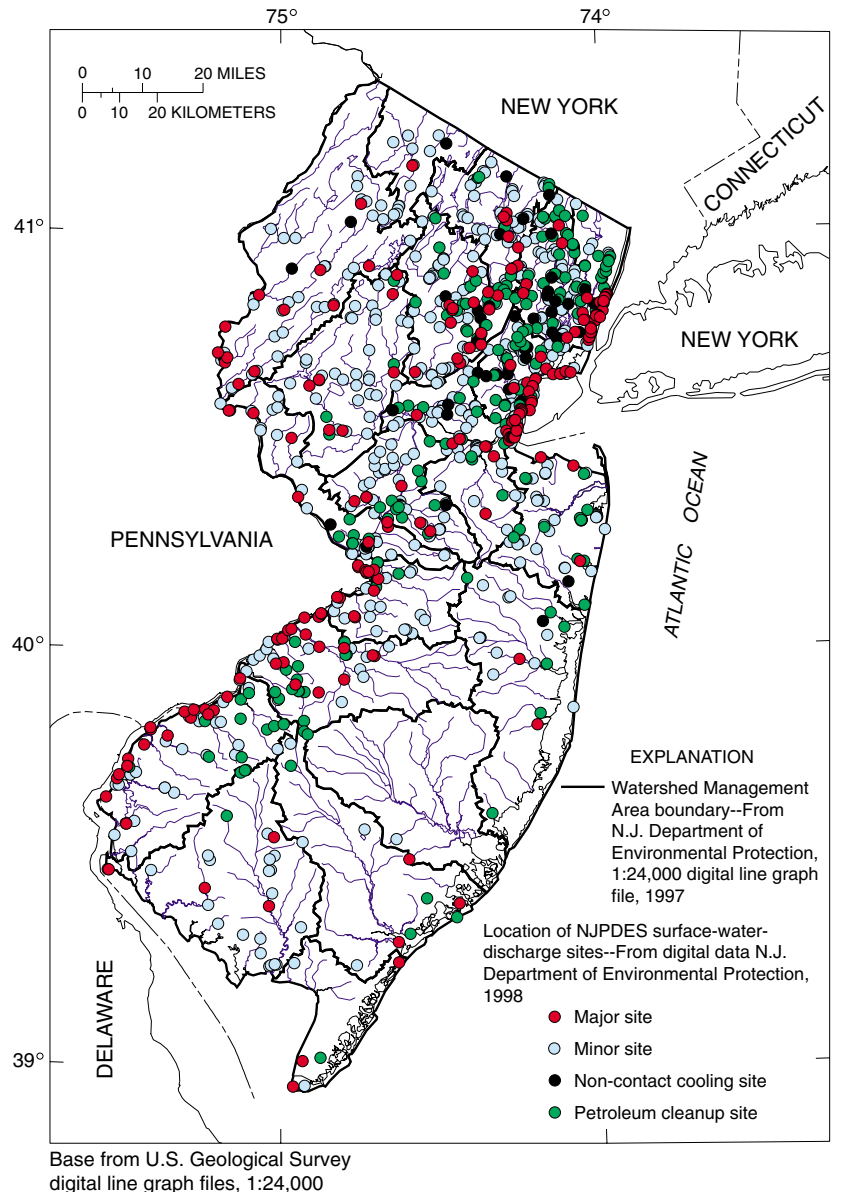

Figure 35. New Jersey Pollutant Discharge Elimination System (NJPDES) surface-water-discharge sites in New Jersey. NJPDES discharge permits are issued to industries, municipalities, or community users that discharge to ground- or surface-water sources. Routine water-quality monitoring of point sources of contamination is required in order to protect and restore the quality of water in New Jersey. 


\section{Landfills and hazardous-waste sites}

Between 10,000 and 15,000 companies in New Jersey engage in the manufacture of chemical and petrochemical products (U.S. Geological Survey, 1986b); many other industries are represented as well. The use, storage, and transport of hazardous chemicals is common throughout the State (U.S. Geological Survey, 1986b). Common causes or sources of contamination of ground water and surface water are chemical spills, improper use and disposal of chemicals, improper disposal of waste, illegal discharges from industrial and other facilities, leachate from landfills, and leaks from storage tanks, to name a few. The location, status, and, in some cases, cleanup of landfills and hazardous-waste sites are monitored by the NJDEP. GIS coverages of the locations of landfills and hazardous-waste sites throughout the State are available from the NJDEP or USGS. Knowing the locations of these sites can help in identifying the source of existing or potential ground- and surface-water contamination problems.

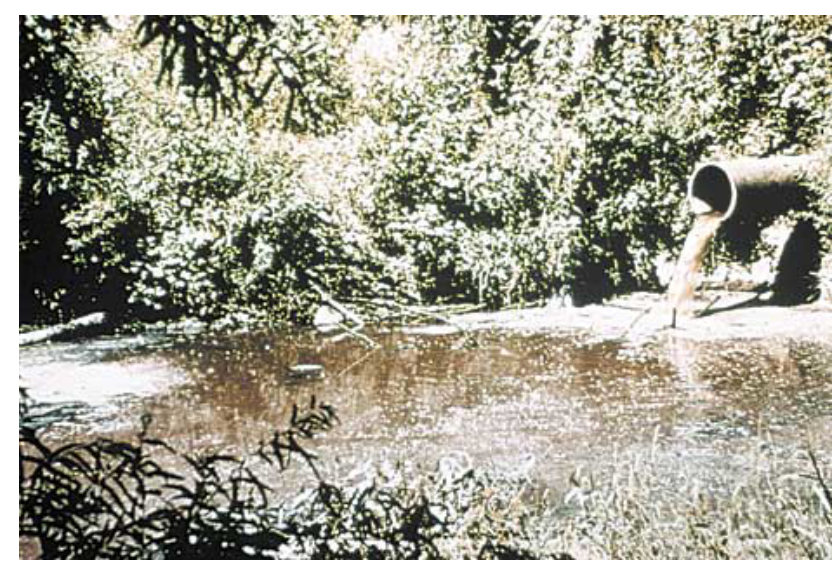

Wastewater discharge to stream. (Photograph by Eric Vowinkel) 


\section{Atmospheric Data}

\section{Weather stations}

Climatological data are collected at 40 stations throughout the State (fig. 36). Data on precipitation, air temperature, soil temperature, snowfall, and evaporation are collected at various stations by the National Weather Service and private observers. This information is published monthly by the National Oceanic and Atmospheric Administration (NOAA). Climatological data (air temperature, precipitation, and snowfall) are collected at many of the stations. At several stations, precipitation data are collected hourly.

Climatological data commonly are used in ground- and surface-water studies. Precipitation amounts and timing of storms are important in studies of streamflow characteristics. They allow investigators to determine the time lag between peak rainfall and maximum discharge in the stream. The relation between monthly precipitation at the Toms River weather station and mean daily discharge at the Toms River near Toms River, N.J., streamflowgaging station is shown in figure 20 . In ground-water studies, the amount and timing of the precipitation can be coupled with a water-level hydrograph to observe the time lag between peak rainfall and rising water levels in the well. Knowing how quickly recharge reaches the water table, in turn, can allow investigators to deduce information about the geologic characteristics of the aquifer material.

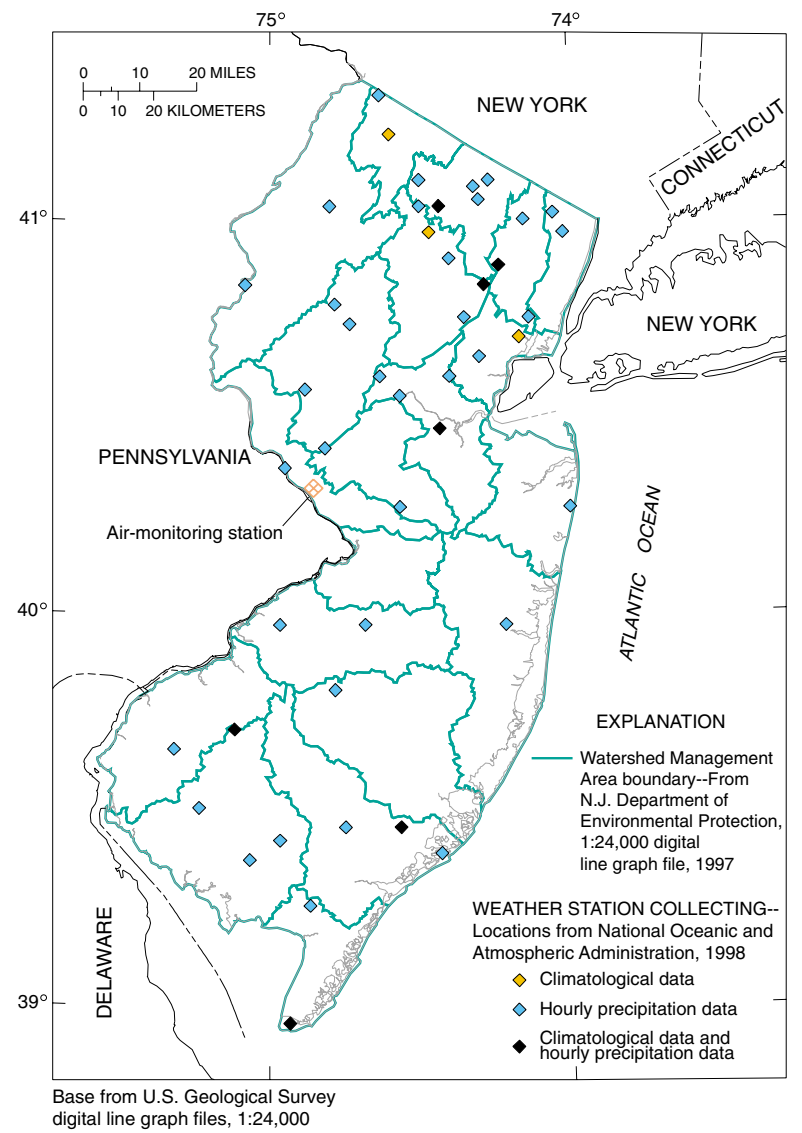

Figure 36. Weather stations and the air-monitoring station in New Jersey. Information collected at weather stations is used in ground- and surfacewater studies. The amount of precipitation and the timing of storms affect streamflow and aquifer recharge. Results of air-monitoring are used by scientists to determine the effects of contaminants in the air on water quality.

\section{Data on precipitation, air temperature, soil temperature, snowfall, and evaporation are collected at various stations by the National Weather Service and private observers.}




\section{Air-monitoring points}

Enormous amounts of man-made and natural material are added to the air every day (J. Gordon and M. Nilles, U.S. Geological Survey, unpub. data titled USGS Tracks Acid Rain, accessed September 17, 1998, on the World Wide Web at URL http:// btdqs.usgs.gov/acidrain/arfs.html, text format). Many industries release metallic trace elements such as lead, copper, zinc, cadmium, cobalt, and chromium into the atmosphere, and the burning of fossil fuels contributes acid-forming substances (Gough and others, 1993). As these materials are carried away by the wind, they may be caught up in the clouds, come in contact with droplets of rain, and fall back to the ground. The contaminants in this precipitation affect the entire ecosystem, killing plants and degrading the quality of the water.

The National Atmospheric Deposition Program/National Trends Network (NADP/NTN) is a nationwide network of precipitation-monitoring sites at which data on the chemistry of precipitation have been collected since 1978. These data allow trends in atmospheric deposition of contaminants to be monitored geographically and over time (National Atmospheric Deposition Program/ National Trends Network, 1997). Deposition occurs not only when it rains and snows, but also when dust settles out of the atmosphere during dry periods. Precipitation samples collected weekly at more than 200 sites nationwide are analyzed for $\mathrm{pH}$, sulfate, nitrate, ammonia, chloride, calcium, magnesium, potassium, and sodium. The USGS supports about 80 of these sites. This information is useful to scientists and students working on environmental studies, industries, government agencies, and anyone involved in environmental regulations, global change, agriculture, and air- and water-quality issues. Maps produced from these data show the locations of the highest and lowest concentrations of constituents and the largest and smallest deposition. One of these sites, which has been in operation since August 1981, is located in Washington Crossing, N.J., just north of Trenton (fig. 36). This information can be accessed on the World Wide Web at http://nadp.nrel.colostate.edu/ NADP.

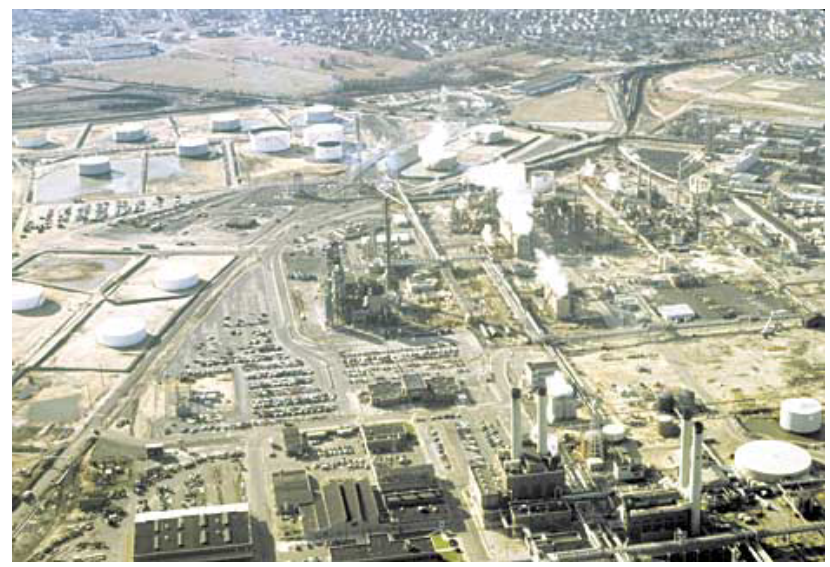

Industrial emissions into the atmosphere along the lower Delaware River, New Jersey. (File photograph, U.S. Geological Survey, West Trenton, New Jersey) 


\section{HOW TO GET INVOLVED}

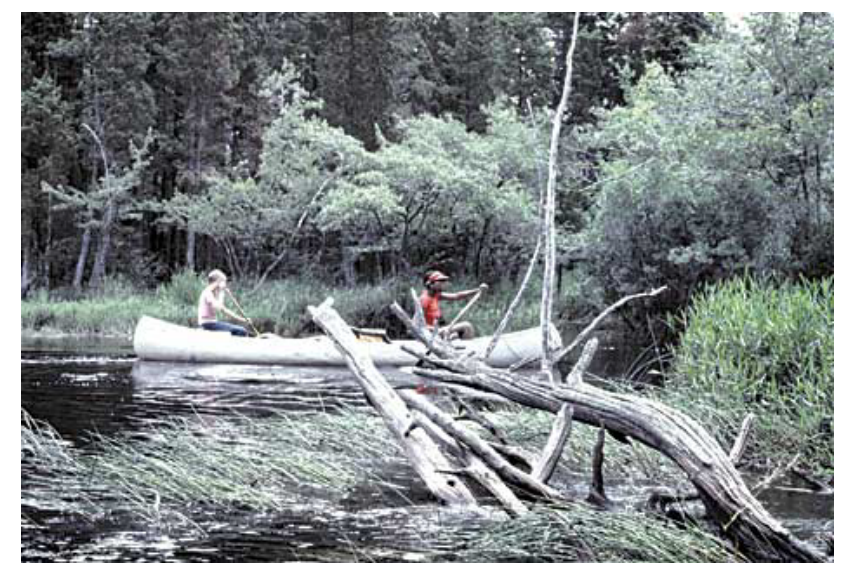

Canoeing on the Batsto River. (Photograph by
Robert Nicholson)

You can get involved in helping to protect and restore the integrity of our water resources. You can take action in your own home or in your community. Simple actions such as proper lawn care, reducing fertilizer applications, using less harmful household products, cleaning up after your pet, and maintaining your septic system can contribute to environmental preservation.

Involvement on the community level might be the next step. Many statewide and regional associations that focus on water protection welcome citizen participation. Call your local government offices to inquire whether your township has an environmental commission or watershed organization. If one is not available, you might consider starting your own. Awareness activities can be organized to reach out to the community and provide information about the value of the local resources and what can be done to protect them. Activities such as cleanup days to remove trash and debris from streams and lakes; storm-drain stenciling to make the community aware that stormwater ends up in the local waterways; recreational events, such as canoeing; volunteering to speak to classes at local schools about the environment; and monitoring soil erosion or the quality of water in the streams are all ways to become involved. Municipal and county government offices may already have ongoing programs that need members. Call your local environmental commission, board of public works, planning board, county soil conservation district, or health department to get involved (N.J. Department of Environmental Protection, 1997d). 


\section{LIST OF CONTACTS}

Environmental groups and watershed associations in New Jersey currently number more than 60. Some groups are statewide whereas others are associated with specific watersheds. The objectives of the Watershed Partnership of New Jersey are to establish a watershed resources network, enhance watershed awareness through education, encourage community watershed involvement, and strengthen partnerships between watershed groups. General information on many of these groups can be obtained by writing or checking the web site:

\author{
Watershed Partnership of New Jersey \\ New Jersey Audubon Society \\ 600 Route 47 North \\ Cape May Court House, NJ 08210 \\ Contact: Dale Rosselet \\ Web site: http://www.wpnj.org
}

The NJDEP, Division of Watershed Management, has a leading role in watershed management throughout the State as well as providing education and outreach information. Programs and publications for use in watershed education and outreach activities are available. Call, write, or visit the web site:

N.J. Department of Environmental Protection Division of Watershed Management P.O. Box 418 Trenton, NJ 08625-0418

Phone: 609-292-2113

Contact: Kyra Hoffman

Web site: http://www.state.nj.us/dep

The USGS, which is part of the U.S.

Department of the Interior, studies water supply, flooding, droughts, and a variety of other naturalresource issues through cooperative programs with State, county, and local governments. Data collected on water levels, water quality, water use, and streamflow can be obtained from the USGS. Data collected through the various networks and projects are important in construction projects, environmental studies, and recreation-planning activities. The USGS also has a bibliography of reports and educational information available. Call, write, or visit the web site:

\section{U.S. Geological Survey 810 Bear Tavern Road Suite 206 West Trenton, NJ 08628 \\ Phone: 609-771-3900 Contact: Eric Evenson, District Chief Web site for the New Jersey District: http://wwwnj.er.usgs.gov}

Additional web sites for the USGS are:

USGS home page: http://www.usgs.gov

Water Resources Division:

http://water.usgs.gov

Water education site:

http://water.usgs.gov/droplet

National Mapping Division:

http://mapping.usgs.gov

Geologic Division: http://geology.usgs/gov

Biological Resources Division:

http://www.nbs.gov

National Water Use:

http://water.usgs.gov/public/watuse

USGS Learning Web:

http://water.usgs.gov/education 


\section{SUGGESTED READING}

The Clean Water Book--Lifestyle Choices for Water Resources Protection

Available from NJDEP, Division of Watershed Management, 92 pages

This booklet presents simple ideas on how to reduce nonpoint-source contamination by the things we do every day. Ideas on topics such as car, lawn and garden, and pet care; managing your septic system or underground storage tanks; and protecting the shoreline are included.

Home-A-Syst--An Environmental Risk Assessment Guide for the Home

Available from Rutgers Cooperative Extension, 124 pages

A workbook for self-assessment of your home and property for contamination and health risks. For rural and suburban homeowners who want to learn how to manage their homes to reduce their effects on the natural system. Additional references and phone numbers are available on each topic covered. Copies can be obtained through Rutgers Cooperative Extension, 80 Nichol Avenue, New Brunswick, NJ 08901, (732) 932-8264 ext. 10.

Watershed Partnership for New Jersey--New Jersey Watershed Education and Resource Directory 1998

Available from NJDEP, Division of Watershed Management, 66 pages

A list of all environmental groups statewide and by water region. Names, phone numbers, and a brief description of each group are included.

Planning for Clean Water--The Municipal Guide

Available from NJDEP, Division of Watershed Management, 64 pages

This booklet provides an overview of nonpointsource and stormwater concerns that need to be addressed during the municipal planning process. Case studies of success stories in New Jersey are included.

Ground Water and Surface Water--A Single Resource
Available through the USGS, U.S. Geological Survey Circular 1139, 79 pages

A general educational document explaining ground water and surface water and the interaction between the two. Copies can be obtained through the USGS, Branch of Information Services, Box 25286, Denver, CO 80225, (303) 202-4700.

\section{Ground Water and the Rural Homeowner}

Available through the USGS, general interest publication, 37 pages

A basic but comprehensive description of ground water. Potential problems one may encounter with ground water and solutions to these problems are discussed. Copies can be obtained through the USGS, Branch of Information Services, Box 25286, Denver, CO 80225-0286, (303) 202-4700.

Let it Flow--A Guide to Finding Water Resources Information in New Jersey

Available through Rutgers Cooperative Extension, 44 pages

A practical guide to help you find information on water resources. Areas of interest that are covered include government agencies with waterresources function and (or) responsibility, nonprofit organizations, nonpoint-source contamination, watershed protection and management, onsite wastewater disposal and drinking water, water conservation, and ground water. Copies can be obtained by writing Rutgers Cooperative Extension, 80 Nichol Ave., New Brunswick, NJ 08901, (732) 932-8264 ext. 10.

\section{Water Quality Monitoring Networks}

Available through the NJDEP, Division of Science and Research, 28 pages

This document gives a brief description of many of NJDEP's monitoring programs. Sampling locations are shown, constituents measured are listed, and a brief history of the program is provided. 


\section{SELECTED REFERENCES}

Ayers, M.A., Wolock, D.M., McCabe, G.J., Hay, L.E., and Tasker, G.D., 1994, Sensitivity of water resources in the Delaware River Basin to climate variability and change: U.S. Geological Survey Water-Supply Paper 2422, 42 p.

Baldwin, H.L., and McGuinness, C.L., 1966, A primer on ground water: U.S. Geological Survey, Washington, D.C., U.S. Government Printing Office, $26 \mathrm{p}$.

Campbell, J.B., 1987, Introduction to remote sensing: New York, The Guilford Press, 551 p.

CH2M Hill, Metcalf and Eddy Inc., and NJ First Inc., 1992, New Jersey statewide water supply master plan, Task 2 report: November 1992, Prepared for the NJ Department of Environmental Protection, 10 volumes revised periodically on a rotating basis.

Durrance, E.M., 1986, Radioactivity in geology-Principles and applications: Chichester, West Sussex, England, Ellis Horwood Limited, 441 p.

Ellis, W.H., Jr., and Price, C.V., 1995, Development of a 14-digit hydrologic coding scheme and boundary data set for New Jersey: U.S. Geological Survey Water-Resources Investigations Report 95-4134, 1 sheet.

Fetter, C.W., Jr., 1980, Applied hydrogeology (2d ed.): New York, MacMillan Publishing Company, 592 p.

Federal Emergency Management Agency, 1988, Guide to flood insurance rate maps: Federal Emergency Management Agency FIA-14, 35 p.

Franke, O.L., Reilly, T.E., Pollock, D.W., LaBaugh, J.W., 1998, Estimating areas contributing recharge to wells--Lessons from previous studies: U.S. Geological Survey Circular 1174, 14 p.
Gillespie, B.D., and Schopp, R.D., 1982, Low-flow characteristics and flow duration of New Jersey streams: U.S. Geological Survey Open-File Report 81-1110, 164 p.

Gough, L.P., and others, 1993, Understanding our fragile environment--Lessons from geochemical studies: U.S. Geological Survey Circular 1105, $34 \mathrm{p}$.

Heath, R.C., 1983, Basic ground-water hydrology: U.S. Geological Survey Water-Supply Paper 2220, 84 p.

Hem, J.D., 1985, Study and interpretation of the chemical characteristics of natural water $(3 \mathrm{~d}$ ed.): U.S. Geological Survey Water-Supply Paper 2254, 263 p.

Johnson, M.L., and Charles, E.G., 1997, Hydrology of the unconfined aquifer system, Salem River area: Salem River and Raccoon, Oldmans, Alloway, and Stow Creek Basins, New Jersey, 199394: U.S. Geological Survey Water-Resources Investigations Report 96-4195, 5 sheets.

Johnson, M.L., and Watt, M.K., 1996, Hydrology of the unconfined aquifer system, Mullica River Basin, New Jersey, 1991-92: U.S. Geological Survey Water-Resources Investigations Report 94-4234, 6 sheets.

Jones, W.D., and DeLuca, M.J., 1998, Water resources data, New Jersey, water year 1997, v. 2--Ground-water data: U.S. Geological Survey Water-Data Report NJ-97-2, 226 p.

Keller, E.A., 1979, Environmental geology (2d ed).: Columbus, Ohio, Charles E. Merrill Publishing Company, $548 \mathrm{p}$. 


\section{SELECTED REFERENCES--CONTINUED}

Kennen, J.G., 1998, Relation of benthic macroinvertebrate community impairment to basin characteristics in New Jersey streams: U.S. Geological Survey Fact Sheet FS-057-98, 6 p.

Langbein, W.B., and Iseri, K.T., 1960, General introduction and hydrologic definitions: U.S. Geological Survey Water Supply Paper 1541-A, $29 \mathrm{p}$.

Lear, Gary, 1997, Inside rain--A look at the National Atmospheric Deposition Program: Champaign, Ill., National Atmospheric Deposition Program, Illinois State Water Survey, 24 p.

Leopold, L.B., and Langbein, W.B., 1960, A primer on water: U.S. Geological Survey Report, Washington, D.C., U.S. Government Printing Office, $50 \mathrm{p}$.

Manahan, S.E., 1990, Environmental chemistry, (4th ed.): Boca Raton. Fla., Lewis Publishers, 612 p.

1997, Environmental science and technology: Boca Raton. Fla., Lewis Publishers, 641 p.

McCann, Allyson, 1992, What is a watershed?: Hawaii Cooperative Extension Service, College of Tropical Agriculture and Human Resources, University of Hawaii at Manoa, Bulletin WQ-5, $2 \mathrm{p}$.

National Atmospheric Deposition Program/National Trends Network, 1997, Wet deposition in the United States, 1996: Champaign, Ill., Illinois State Water Survey, 10 p.

National Oceanic and Atmospheric Administration, 1928-1998, Climatological data for New Jersey, 1927-1998 (published monthly).
Nawyn, J.P., 1997, Withdrawals of ground water and surface water in New Jersey, 1994: U.S. Geological Survey Fact Sheet FS-120-97, 4 p.

1998, Withdrawals of ground water and surface water in New Jersey, 1991-92: U.S. Geological Survey Open-File Report 98-282, 57 p.

Nawyn, J.P., and Clawges, R.M., 1995, Withdrawals of ground water and surface water in New Jersey, 1989-90: U.S. Geological Survey Open-File Report 95-324, 52 p.

New Jersey Department of Environmental Protection, 1979, Upper Raritan water quality management plan: Trenton, N.J., New Jersey Department of Environmental Protection, May $1979,525 \mathrm{p}$.

1996a, Executive summary--Ambient biomonitoring network, Atlantic Coastal Drainage Area, 1994-95, Benthic macroinvertebrate data: Trenton, N.J., New Jersey Department of Environmental Protection, Division of Science and Research, Water Monitoring Management, January 1996, 29 p.

1996b, New Jersey 1996 State water quality inventory report: Trenton, N.J., New Jersey Department of Environmental Protection, Policy and Planning, Office of Environmental Planning, $363 \mathrm{p}$.

1996c, The vital resource--New Jersey statewide water supply plan: Trenton, N.J., New Jersey Department of Environmental Protection, Policy and Planning, Office of Environmental Planning, August 1996, 173 p. 


\section{SELECTED REFERENCES--CONTINUED}

1997a, Federal and New Jersey State primary and secondary drinking water standards as of November 1996: Trenton, N.J., New Jersey Department of Environmental Protection, Water Supply Element, Bureau of Safe Drinking Water, November 1997, pamphlet.

1997b, Pollutant discharge elimination system: New Jersey Administrative Code, Title 7, Chapter 14A, Trenton, N.J., New Jersey Department of Environmental Protection, June 1997.

$1997 \mathrm{c}$, Statewide watershed management framework document for the State of New Jersey (Draft): Trenton, N.J., New Jersey Department of Environmental Protection, Office of Environmental Planning, January 1997, 78 p.

1997d, The clean water book--Lifestyle choices for water resources protection: Trenton, N.J., New Jersey Department of Environmental Protection, Office of Environmental Planning, May 1997, 92 p.

1998a, BAYNET biomonitoring network, Atlantic Coastal Drainage Area, 1996 benthic macroinvertebrate data: Trenton, N.J., New Jersey Department of Environmental Protection, Division of Science and Research, Water Monitoring Management, May 1998, 51 p.

1998b, Surface water quality standards: Trenton, N.J., New Jersey Department of Environmental Protection, Environmental Planning and Science, Office of Environmental Planning, April 1998, 122 p.

1998c, Standards for safe drinking water in New Jersey: Trenton, N.J., New Jersey Department of Environmental Protection, Water Supply Element, Bureau of Safe Drinking Water, August 1998, pamphlet. 1998d, Water quality monitoring networks: Trenton, N.J., New Jersey Department of Environmental Protection, Division of Science and Research, Water Monitoring Management, February $1998,28 \mathrm{p}$.

New Jersey Department of Labor, 1991, New Jersey population trends 1790-1990: Trenton, N.J., New Jersey Department of Labor, N.J. State Data Center, 70 p.

Nicholson, R.S., and Watt, M.K., 1998, Simulation of ground-water-flow patterns and areas contributing recharge to streams and water-supply wells in a valley-fill and carbonate-rock aquifer system, southwestern Morris County, New Jersey, 1998: U.S. Geological Survey Water-Resources Investigations Report 97-4216, 40 p.

Puckett, L.J., 1995, Identifying the major sources of nutrient water pollution: Environmental Science and Technology, v. 29, no. 9, p. 408A-414A.

Reed, T.J., Centinaro, G.L., DeLuca, M.J., Hutchinson, J.T., and Scudder, J.J., 1997, Water resources data, New Jersey, water year 1996, v. 1--Surface-water data: U.S. Geological Survey Water-Data Report NJ-96-1, 562 p.

Reed, T.J., Centinaro, G.L., DeLuca, M.J., and Oden, J.H., 1998, Water resources data, New Jersey, water year 1997, v. 1--Surface-water data: U.S. Geological Survey Water-Data Report NJ-97-1, $608 \mathrm{p}$.

Ruddy, B.C., and Hill, K.J., 1990, Summary of selected characteristics of large reservoirs in the United States and Puerto Rico, 1988: U.S. Geological Survey Open-File Report 90-163, 295 p.

Ruhe, R.V., 1975, Geomorphology, geomorphic processes and surficial geology: Boston, Mass., Houghton Mifflin Company, 246 p. 


\section{SELECTED REFERENCES--CONTINUED}

Searcy, J.K., 1959, Flow-duration curves--Manual of hydrology: Part 2. Low-flow techniques: U.S. Geological Survey Water-Supply Paper 1542-A, $33 \mathrm{p}$.

Shelton, T.B., 1994, Interpreting drinking water quality analysis--What do the numbers mean?: New Brunswick, N.J., Rutgers Cooperative Extension E185, 67 p.

Solley, W.B., Pierce, R.P., and Perlman, H.A., 1998, Estimated use of water in the United States in 1995: U.S. Geological Survey Circular 1200, $71 \mathrm{p}$.

Summer, W.M., 1998a, New Jersey tide-telemetry system: U.S. Geological Survey Fact Sheet FS091-98, 2 p.

1998b, Passaic flood warning system: U.S. Geological Survey Fact Sheet FS-092-98, 2 p.

1998c, Somerset County flood-information system: U.S. Geological Survey Fact Sheet FS090-98, 2 p.

Swenson, H.A., and Baldwin, H.L., 1965, A primer on water quality: U.S. Geological Survey, Washington, D.C., U.S. Government Printing Office, $27 \mathrm{p}$.

U.S. Environmental Protection Agency, 1990, Secondary maximum contaminant levels (section 143.3 of part 143, National secondary drinkingwater regulations): U.S. Code of Federal Regulations, Title 40, Parts 100 to 149 , revised as of July 1, 1990, p. 674.

U.S. Geological Survey, 1985, National water summary 1984--Hydrologic events, selected waterquality trends, and ground-water resources: U.S. Geological Survey Water-Supply Paper 2275, p. 309-315.

1986a, National water summary 1985--Hydrologic events and surface-water resources: U.S.
Geological Survey Water-Supply Paper 2300, p. 335-340.

1986b, National water summary 1986-Ground-water quality: U.S. Geological Survey Water-Supply Paper 2325, p. 369-376.

1990, National water summary 1987--Hydrologic events and water supply and use: U.S. Geological Survey Water-Supply Paper 2350, p. 367-374.

1991, National water summary 1988-89-Hydrologic events and floods and droughts: U.S. Geological Survey Water-Supply Paper 2375, p. 401-408.

1994, Multi-resolution land characteristics-Land use in New Jersey: Sioux Falls, S.D., EROS Data Center, remote sensing image from Landsat thematic mapper data, 1991-93 [Available from http://edcwww.cr.usgs.gov/glis/ glis.html].

1996a, Digital orthophotos: U.S. Geological Survey Fact Sheet FS-129-96, 2 p.

1996b, Digital raster graphics: U.S. Geological Survey Fact Sheet FS-122-95, 2 p.

1996c, National water summary on wetland resources: U.S. Geological Survey Water-Supply Paper 2425, p. 279-284.

Wahl, K.L., Thomas, W.O., and Hirsch, R.M., 1995, The stream-gaging program of the U.S. Geological Survey: U.S. Geological Survey Circular 1123, $22 \mathrm{p}$.

Waller, R.M., 1994, Ground water and the rural homeowner: U.S. Geological Survey, Washington, D.C., U.S. Government Printing Office, 37 p. (booklet). 


\section{SELECTED REFERENCES--CONTINUED}

Watt, M.K., and Johnson, M.L., 1992, Water resources of the unconfined aquifer system of the Great Egg Harbor River Basin, New Jersey, 1989-90: U.S. Geological Survey WaterResources Investigations Report 91-4126, 5 sheets.

Watt, M.K., Johnson, M.L., and Lacombe, P.J., 1994, Hydrology of the unconfined aquifer system of the Toms River, Metedeconk River, and Kettle Creek Basins, New Jersey, 1987-90: U.S. Geological Survey Water-Resources Investigations Report 93-4110, 5 sheets.

Winter, T.C., Harvey, J.W., Franke, O.L., and Alley, W.M., 1998, Ground water and surface water--A single resource: U.S. Geological Survey Circular $1139,79 \mathrm{p}$.

Zapecza, O.S., 1989, Hydrogeologic framework of the New Jersey Coastal Plain: U.S. Geological Survey Professional Paper 1404-B, 49 p., 24 pl. 